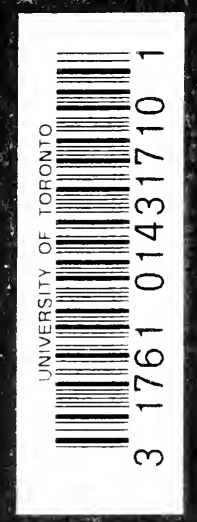









THE STUDY OF NATURE AND THE VISION OF GOD : WITH OTHER ESSAYS IN PHILOSOPHY 
Then, if that is his motive, he will not be a statesman.

By the dog of Egypt, he will! in the city which is his own he certainly will, though in the land of his birth perhaps not, unless he have a divine call.

I understand; you mean that he will be a ruler in the city of which we are the founders, and which exists in idea only; for I do not believe that there is such an one anywhere on earth ?

In heaven, I replied, there is laid up a pattern of it, methinks, which he who desires may behold, and beholding, may set his own house in order. But whether such an one exists, or ever will exist in fact, is no matter; for he will live after the manner of that city, having nothing to do with any other.

I think so, he said.

-Plato, Republic, 592 (tr. Jowett). 
The Study of Nature and the Vision of God: with Other Essays in Philosophy 
Entered according to Act of the Parliament of Canada, in the year one thousand nine hundred and seven, by George John Blewett, at the Department of Agriculture. 
MORTVIS MEIS 


\section{PREFACE.}

IN the endeavour of man to draw near to that ultimate reality with which it is his salvation to make himself at one-the endeavour which is on its practical side religion, on its theoretical side philosophy and theology-there is an elemental distinction between two tendencies or methods. The one, to find God, denies the world. The other retains the world, but when God is found the world becomes new; or rather, in finding God the world also is found, for the knowledge of God is the ultimate truth about the world. To trace these tendencies, in the broad outline of their historical relations of conflict and of combination, was once the hope of the present writer. Such a study, if it could have been undertaken successfully, would have done two things: would have cast light on the forms which in human history the religious endeavour to be at one with God has assumed; and would have marked out for students, in an elementary but yet fundamental way, the ground-currents of the history of philosophy and theology. But it is now almost certain that that plan will never, even in briefest outline, be carried through; and so a number of essays, written at different times and under different circumstances as studies toward it, are published here as separate papers. Each can be read by itself; yet, since there is enough of the original plan in the separate parts to give them a certain unity, it would be better to take them together as forming a single historical discussion. For this reason a short introduction has been prefixed, stating the main point of the discussion and the relation of each of the papers to it.

The essay on Spinoza is the property of Harvard University, and is published here by permission of President Eliot. ${ }^{1}$ This is only a single instance of the kindness with which through many years that great university has treated Canadian students; though we came to 1 A few changes have been made. 
her as strangers, she admitted us ungrudgingly to the use of her wide resources, and by a hospitality more generous than can be told in words bound to herself our hearts. I can scarcely record here the names of all those who at Harvard, whether by mastery in the things of the mind, or by personal kindness, placed me in their debt; but those who have a better right than I can perhaps allow me to refer with a gratitude made deeper by the sense of loss, to the gifted lady who left all the world of New England poorer when she was taken in sudden death from the place at the side of Professor Palmer which she filled with such grace and power.

I am deeply indebted also to several of those who in old-world universities are carrying forward the greater traditions of philosophy; nor is my sense of obligation lessened by the fact that they would disapprove of many things in these pages. The thoughtfulness of Professor Külpe, and the charm of his grave sincerity, brightened for me a time at Würzburg when work was almost out of question. To the kindness of the Master of Balliol I must refer with the special reverence and gratitude due to one whose venerable primacy in philosophy among English-speaking men makes him "our father Parmenides." And I must mention one other name: that of the late Thomas Hill Green, whose living voice I had never the happiness to hear, but whose Prolegomena to Ethics-since Cudworth's day the greatest single piece of constructive work in the British literature of metaphysic and ethics-was my "introduction" to the study of philosophy.

But the masters in the schools of philosophy will find no fault with me, if with the deepest gratitude of all I mention an influence other than their own, though not alien to it-that of three men who live now in God: Lesslie Matthew Sweetnam, who bore without flinching a fiery trial of pain, and went early to death, giving his own life in the attempt to save by operation that of a helpless stranger - being in his death what he had been in life, a prince among the surgeons of his day, and a man whose character was a magnificence of the spirit; John Petch, sometime Professor of French in Victoria College, Toronto, who throughout the long and painful illness which preceded his death, showed to those who waited upon him the same 
affectionate consideration and gentle courtesy that (joined with the finest sense of honour) had become in the days of his strength the settled habit of his mind; and my father, a brave and gifted man, who endured wrong in silence, and in spite of a frail body and the cruelty of circumstance discharged with fidelity the greater human duties, and to whom at last there came gently the grace of sudden death. To these three men, who were strong enough not to play the rebel's part when their doom was hard, but had their hope in God, and did with their might their work upon the earth, the pages which follow are inscribed; and it is the writer's grief that to their dear and lamented names he is not able to erect a more worthy monument.

Victoria College,

Toronto, January, 1907. 


\section{CONTENTS.}

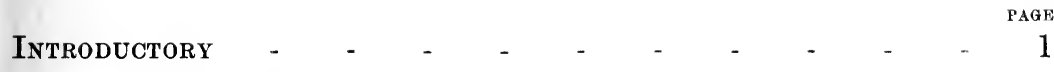

The Study of Nature and The Vision of God - $\quad$ - 15

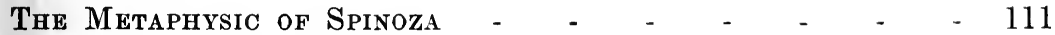

Plato and the Founding of Idealisi $\quad$ - $\quad$ - $\quad$ - $\quad$ - 201

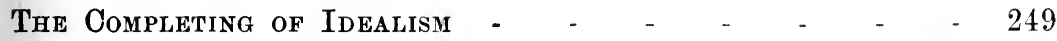

Erigena: The Division of Nature - $\quad$ - $\quad$ - $\quad$ - $\quad$ - $\quad$ - 269

Erigena's general position - $\quad$ - $\quad$ - $\quad 271-280$

The four Forms of Nature $\quad$ - $\quad$ - $\quad$ - $\quad$ - $\quad 280-331$

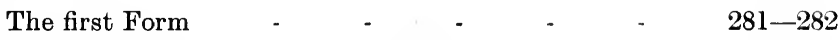

The procession from the first Form to the second - $282-298$

The procession from the second Form to the third $298-310$

The return of all things-the fourth Form of Nature $\quad 310-331$

The Theism of St. Thomas

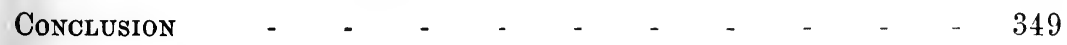




\section{INTRODUCTORY}

When some great Christian kingdom has along its borders no rest from war, many young citizens-the lion being still supreme in them ${ }^{1}$ - can recognise but one service of the state. The watch upon the frontier, with its discipline of arms and its incessant energies of defense and attack, is to them at once the duty of a man and the meaning of citizenship and the ideal life. But the years bring a graver wisdom; the man who went out eagerly to the tented field-if he has retained the clear sense of devotion to the state, and has not become merely subdued to the trade of war-comes more and more to see that, great as is his present service to the state, there is another, quieter and greater. The ultimate strength of the state lies otherwhere: in patient processes and structures of industry and commerce and legislation; in unnumbered school-rooms; in those ancient houses where learning is cherished for its own sake, and for their own sake the sciences are cultivated, and out of piety the memory of far-off benefactors is kept alive; above all, in the "relations dear" of the homes, with their "charities of father, son, and brother," and their establishment in uprightness and integrity of the characters of those who presently are to do the world's work and shape the world's life; and in those companions of the homes, without which homes are scarcely homes at all, the parish churches that with sacraments and holy observances and the making of habitual prayer lie close to our mortal life from its beginning to its close:-parish churches where the vows of baptism are made for little children; and with Morning Prayer and Evensong the growing life is reminded day by day of the heavenly glory which is its end; and to each relationship of life, with all that is in it of labour or sacred promise or discipline of grief, there is brought by solemn offices the assistance of the heavenly grace; and all, at last, the young with the old, the poor side by side with the great, lay themselves down together to their sleep 


\section{INTRODUCTORY}

in the shadow of the ancient walls. In these things is the strength and true life of the state; nay, these things are the state; and to them the man upon the frontier-if he is a man indeed, and the times are not too grim-makes soon or late his way, leaving the vigil upon the border to the younger men with whom the inward and spiritual voices of the rational soul have not yet come to mastery and the call of the trumpet remains the one voice of duty.

In our day there has been something similar to this in the commonwealth of philosophy. It too has had its border-warfare: the strife between those who had, and those who had not, grasped the ancient and cardinal insight of philosophy, that if you would understand the nature of the world you must understand the relation of the world to the soul. That insight received its first systematic application, in a form singularly impressive and splendid, from Plato. And to win it again and learn how to carry it once more to its systematic application, has been precisely the work of recent philosophy; a work undertaken upon the impulse and suggestion of Immanuel Kant. Kant compelled us to see that in any attempt to form a view of the world we must remember from the beginning that the facts of the world-all facts that any man of science can in any sense investigate-are facts for self-consciousness. To say that anything is capable of undergoing scientific investigation is to say that it is capable of becoming present to, of being comprehended by, of having its nature and structure expressed in forms of, the self-conscious spirit which is man. To say that material objects can be known is to say that material objects are capable of entering into organic union with self-conscious intelligence. Indeed, it is not doing justice to the facts of the case to say merely that in knowledge there is a union of subject and object. Throughout the whole process of gaining knowledge the mind itself is active; active in shaping the impressions which are given to us into that objective order of facts in which we live and which we call the world. So that the subject actually bears a part in constructing its own object and its own objective order. Hence, until you have studied that activity of mind, you do not understand how ynur world has come to be what it is; you do not under- 


\section{INTRODUCTORY}

stand the nature and structure of the world of your actual life. To try to understand the nature of the world without reference to the activity of the self-conscious subject, is like trying to solve a problem in neglect of its central factor or to pronounce final verdict upon a case in forgetfulness of the most immediately relevant part of the evidence. Nothing, that is to say, worthy of being called a scientific view of the world-in technical terms, nothing worthy of being called a metaphysic-is possible to a man until he considers the relation of subject and object; or, to state the case more narrowly, until he considers the fact of knowledge and raises the question of the possibility of knowledge. ${ }^{1}$

But in the age immediately preceding our own, philosophy found

1 The statement, in the above paragraph, of the character of our experience, is simply a statement of fact. It is not metaphysic: but it clears the ground for metaphysic, by describing the object with which the metaphysician begins, and the conditions of whose possibility he seeks to understand.

In our own day, this clearing of the ground for metaphysical construction has been effected by the psychologists in a way more primary-if such an expression may be allowed-than was possible to Kant, moving painfully as he did under his accumulation of inherited burdens. For the psychologist, as he goes on with his analysis, never comes to any object other than the psychical object ; in other words, the realities of individual experience are always psychical realities. Hence, any one who passes from psychology to metaphysic is at once in position to argue that, since the process to be explained is altogether psychical, that which explains its possibility must likewise be psychical ; and this, in whichever way the indiridual experience is supposed to be related to the greater (or total) reality whose nature the metaphysician seeks to know-whether as effect to cause, or as part to whole, or as a product or reproduction to a source whose relation to the product is not adequately expressed by the category of cause and effect.

The psychologist, as such, has, of course, no concern about metaphysic at all. His business is simply to observe the facts and processes of individual experience as these actually are. But if he performs that task with accuracy, his work-whether he intends it or no-clears the ground for metaphysical construction as it never has been cleared before; and this puts every department of philosophy under a great debt to him.-In referring to this contribution of the psychologist to metaphysic, I am thinking, of course, not of the older psychology-which was a mixture of metaphysic and psychological observation in which neither component eame to its right-but of the psychology which is psychology and nothing else ; the psychology which, in the logical order of the sciences, is the first of the sciences of observation. This is often called the "new," or "experimental," psychology. But the adjectives are not needed. When the psychologist applies methods of exact measurement to such psychical phenomena as admit of exact measurement, he is doing only what any man of science ought to do. The fact that certain elements and certain processes in our experience admit of fairly exact measurement, does not make experience and the experienced world any the less spiritual or any the more mechanical.-In this connexion I should refer, with warm admiration, to the name of Professor Kirsehmann of the University of Toronto. I do this, not as in any sense suggesting that Professor Kirschmann would approve of the views expressed in these pages; but as indicating my own gratitude to him and to his teaching. 


\section{INTRODUCTORY}

itself face to face with views of the world which were formed by absolutely the opposite procedure and yet were threatening to dominate the world. For there are more metaphysicians in the world than the Platonists and the Kantians. All men are metaphysicians by nature; and most men impatient and hasty metaphysicians. They rush into metaphysic from whatever scientific ground they happen to have been working upon, and construct metaphysical systems with whatever categories they have been accustomed to use, without considering that there is an intervening question-this question of the possibility of knowledge, and of the relation of the categories to nature. The physicist, for example, when he obeys the human impulse to be metaphysical, is tempted simply to treat the physical point of view as the ultimate one, and the categories of physical science as the ultimate categories - the ultimate principles of explanation of the world. Without quite seeing what he is doing-for since he scorns the word "metaphysic," it is easy for him to imagine that he also scorns the thing-he gets a metaphysic of his own at one stroke, by simply taking his physics as metaphysic. That the facts of our experience have relations other than the physical; that an investigation of these might lead to a deeper knowledge of the facts, and even to a re-interpretation of the physical relations themselves; that there is an inquiry (epistemology) which seeks to conduct precisely this investigation:- this he does not see, and, not seeing it, enters boldly and easily upon a world-view which is blind to all aspects of the world but one; and so we get that hasty and premature metaphysic which, when it puts the emphasis at one point, is called Materialism; when at another point, the mechanical view of the world. Then come other men of science who see that materialistic and mechanical views are not adequate as explanations of the world of our experience, but who yet will have nothing to do with the epistemological problem; these, finding the way of advance barred to themselves, assert that it is barred to all men; and thus we get the final development of this type of metaphysic, the development seen in the various forms of Agnosticism.1

1 The Agnosticism here meant is that which may be called Agnosticism for its own sake; not that which, in ancient and mediæral times, was simply one of the momenta of Mysticism. 


\section{INTRODUCTORY}

'These types of metaphysic have in our day exercised an immense influence. In the first place they have been powerful through a sort of transferred glory: the men who have urged them upon us are in many ways our benefactors; are members of that great host to whose untiring labour and magnificent achievement in physical and natural science we are all of us-and none of us more than the theologiansprofoundly indebted. And in the second place their influence has been wide because the movement of thought already described, the movement of thought by which one drifts into them from the modern scientific conscionsness, is so easy and so natural. Certain principles of explanation used upon certain aspects of reality prove splendidly successful; what more easy than to take for granted that these are the supreme principles in the whole arsenal of man's mind? And that view once taken, the conclusions follow directly: either you apply these principles to the explanation of the whole process of the universe, and so gain a materialistic or mechanical view of the world; or you see that there are facts which these principles cannot explain, and then you say that, since these principles are the supreme principles of science, those facts are incapable of scientific explanation and lie beyond the horizon of human knowledge altogether. But, however easy such a movement of thought be, or however attractive to human nature, the present-day student of philosophy who knows his own field-which amounts to saying, who has entered into metaphysic by the gateway of epistemology-has no choice but to insist that views formed in this way are premature, uncritical, dogmatic; they announce their conclusions without having investigated a great problem which is not merely relevant but fundamental.

That is to say, to return to the comparison of a moment ago, such a student recognises in views of this sort the hostile encampments upon the frontier; barbarians having nature's own strength in them and therefore magnificent in intellectual and spiritual potentialities, but seeking to destroy the ancient civilisation of church and state in which alone can the nature in them or in any man come to its true fulfilment.' And while he is still young he is likely to feel it his special vocation to take up the conflict with these; always he is devising some new and clearer statement of Platonic or Kantian 


\section{INTRODUCTORY}

epistemology, such as will set out in plain light the immense and yet rudimentary fallacy of which they are habitually guilty, and without which their systems and their outlook upon the world would never have come into being at all. But as he grows older he finds that he himself has something to learn; not a new lesson exactly, but a new temper. To him as well as to others that graver wisdom of the vears is brought; his heart begins to apprehend, and to respond to, a greater call. If his rocation is to be fulfilled in its integrity, he must pass on to those constructive labours that regard nothing save truth in her eternal form. And to take part in such labours there is but one way: he must turn to the ancient and catholic homes of his great science, must make them the dwelling-place of his mind, in their faith and in the power of their still light must at once look upon and participate in the struggle and fate of man. It is necessary, indeed, that the controversy upon the marches be maintained. But that work of serving God with the sword he may well leave to younger men. In the kingdom of the intellect, the greater service of God is that of those who in peaceful labour draw nearest to His glory; and so, for himself, in the years that are left, he will turn toward that central region where, in their own native and appropriate forms, the greater things of philosophy stand in peace, and the spirits of the masters abide in the temples which they themselves have built. 'There he will dwell, and will seek, so far as he can, both to live over again in himself the great histories which have been enacted there, and to keep the access to those homes of light open to whatever men may be led by trouble of mind or by an inner vocation to turn their faces that way.

But this central and catholic region of philosophy-what is it like? In a moment we shall have to consider the great division which is found in it. But first we must note the distinguishing characters in which all its structures and labours share, and which make it, with all its divisions, still one realm. These characters are, in the main, two; two characters which may seem very broad, very fugitive, very impalpable, to the man who looks upon the matter from the outside; but the opposite of fugitive or impalpable to the man who looks out upon philosophy from its own central point of view. In the first 


\section{INTRODUCTORY}

place, the philosophies which belong here, however radically they differ from one another in other respects, agree in this-they are a wisdom of the soul. They remember that reality is the seat and home of the soul, and that, therefore, in forgetfulness of the soul reality can never be understood or rightly interpreted. In the second place, they agree also in this, that to them truth and life are one. With whatever differences among themselves, they constitute that greater philosophy which, at one and the same time and by one and the same impulse, seeks to know reality and to enter into union with it. On the one side, such philosophy is what the Germans call Wissenschaft, what Plato and Aristotle with a still severer exaltation of meaning called $\dot{\varepsilon} \tau \imath \sigma \tau \eta \mu \eta$, and what in these pages (contrary to the ordinary usage of English men of thought) will be called science. On this side, seeking knowledge for the sake of knowledge, it endeavours to comprehend intellectually the world of which it is itself a part. But the same impulse and the same passion has as its other side the endeavour to be at one with the reality which it has scientifically apprehended. It seeks to take, as its way, the way of that reality; seeks to take the nature of that reality as its guide, the law and informing spirit of that reality as its law and its spirit. And so it is a principle of the unity of life; it seeks the unity of life by seeking that union with ultimate reality in which science and religion are one.

But, as already has been indicated, within the limits of the greater philosophy which has these distinguishing characters, there is a certain profound and thoroughgoing division. In the attempt to apprehend the true nature of reality, and consequently in the endeavour to bring the life of man into accord with reality, there have been two great methods, two great tendencies, the distinction between which is not broken down by the fact that historically they have entered into the most manifold relations of combination and of conflict with each other. The division arises, as all great human divisions arise, from the existence of divergent tendencies in human nature itself, and of radical differences in the experience, happy or tragic, which falls to the lot of individuals and races. And since it arises in the effort to apprehend ultimate reality, it is a division elemental and ultimate- the most radical of all the divisions known 


\section{INTRODUCTORY}

to human nature and human life, and the one that must always be kept in mind, as a sort of ground-plan, in any attempt to understand the spiritual history of man. The tendencies themselves, however, and the two types of philosophy to which they give rise, we must seek to understand somewhat more fully.

Each of the two types of philosophy is a movement from the changing and transient facts of the experienced world to a principle which is one and eternal; or, as this would usually be expressed, is a movement from the world to God. But each makes that movement in its own way. The one, in moving from the world to God, does not forget the world from which it started. When it finds the explanation of the world in a vision of God, it returns to the world, and seeks to give to the facts of the world their true interpretation in the light of that vision of God. The facts of the world and of our life are to it elements in a divine plan, the history of the world a process in which an eternal purpose is being realised. The nature of Godand therefore, however veiled by cloud and storm, the nature of the world-is that for which human language has no single word, ${ }^{1}$ but which may be expressed by putting together the three words, reason, righteousness, love. And in unity with that true or ultimate nature of the universe lies the way of life for man; in character, unity with the divine character; in action, unity with the divine purpose. Since, furthermore, the purpose of God is the ultimate law of the world, since the plan of God realises itself in and through the history of the world, that character and action in which man seeks to become at one with God must be character and action in this present world, not out of it. It is in and through the ways of this present life, in and through the "daily round " and the "common task," in and through the regular forms and relationships, the normal duties and affections, of human work and human homes, that a man must make himself at one with the eternal reality. Even as there is "no other genuine enthusiasm for humanity," so also, to extend the late Professor Green's well-known statement, there is on this view no other genuine enthusiasm for God and for the eternal, than one "which has travelled the common highway of reason-the life of the good neigh-

\footnotetext{
1 Unless it be the word "spirit," in its concrete sense.
} 


\section{INTRODUCTORY}

bour and the honest citizen-and can never forget that it is still only a further stage of the same journey."

The other tendency follows just the opposite procedure. In moving toward God it leaves the world behind. For the reality, knowledge of which is truth, and union with which is the way of life-is it not something essentially different from these present appearances?-if not, why are we dissatisfied with these appearances? What, indeed, sets us at all upon that quest which, as thinking, is philosophy, but as a life is religion, save precisely this, that the appearances which constitute our present experience and our present world are profoundly unsatisfactory? They are transient-they fleet away and leave life empty for the man that trusted in them. Logically, they are self-contradictory. Morally and religiously they are inadequate, if indeed they do not stand absolutely condemned. Then how shall we define reality save by denying of it the characters of the appearances which make up our experience? And so reality comes to be conceived, not as that which at once explains and contains the things and forms of our present life, the home of them and the truth of them, their law and their informing spirit, but as something which exists purely in itself and cannot be given to us under the ordinary forms of our thinking. On the contrary, it can be described only by denying of it all the characteristics of what can be so given to us. It is true that the men who seek reality by this method usually have, explicitly or implicitly, formal definitions of itdefinitions of which the ancient and ever-recurring one, that " substance is that which for its existence stands in need of nothing but itself," is a type. But no positive or concrete characterisation is possible-when reality is described as one, eternal, unchangeable, these are not so much positive characters as negations of the multiplicity, the diversity, the change and transience, of that which is given to us and is our experience. For, as we have just seen, the very method by which the real is sought to be reached makes impossible any attempt to tell what its positive content or nature is. The forms, the energies, the activities, which are manifest in our experience, and make our world what it is-what you know about reality is that it is not these. There is a reality, indeed-that is your first and 


\section{INTRODUC'TORY}

profoundest conviction as a denier of this false world in the name of the truly real $;^{1}$ and that reality needs for its existence nothing save itself ; but you are sure that it, as it is in itself, is never given to you, and cannot be given to you, under the ordinary form of your experience. And so, in your search for reality, you must say of any natural or intellectual or moral form known to man's present experience, "It is not that."

In a word, this philosophy, when it has gained its goal and its rest in God, remembers the world no more, except as a dream and an illusion which, at the coming of the vision of God, has vanished back into its own native and original nothingness. Reality is that which the world of our experience is not. And as reality is conceived, so also is the true way of life conceived. All that you can say of the consciousness or experience which is at one with reality, is that it is not our present consciousness; that it has no kinship in form or procedure with the normal consciousness manifest in man's ordinary science and labour, religion and society; that even such terms as "consciousness" or "experience" can be applied to it only by accommodation.

Of all the divisions or distinctions that are found in human experience and have been influential in shaping the world's history, this is-in the sense of being first and elemental-the most important. Its fullest and most concrete expression of itself has been, of course, in religion. On the one side stand religions like Brahmanism (and, in a modified sense, Buddhism) - the religion of men who deny the world and seek to become one with a reality which is not the changing world $;^{2}$ on the other, religions like Christianity, which see that it is only in God and unto God that the world reaches its truth and reality. Indeed, if one were speaking of Christendom-still more, if one were speaking of the church-rather than of Christianity, one would have to say that its history is a history precisely of the conflict of these two tendencies within one body. And naturally, as to some extent

\footnotetext{
1 Though you may feel compelled to object to all possible human ways of expressing that conviction.

2 "You let your boat drop quietly down the Ganges to-day, and along its banks the silent figures sit like carved brown statues, hour after hour, day after day, with eyes open and fixed on vacancy, clearing themselves of all thought, emotion, and desire, that, being emptied of self, they may see God."-[I cannot find the reference.]
} 


\section{IN'TRODUCTORY}

we have seen already, this deepest distinction in man's practical life has expressed itself also, in every age and in numberless ways, in his endeavour rationally to comprehend himself and his life, whether that attempt be called philosophy or theology. Indeed, the man who attempts to understand the history of philosophy, or of theology (in the ancient sense of the term), without understanding this distinction and its place in those histories, is like a man of science who should examine the surface of some great current, without penetrating to the forces that actually have determined and actually are determining its nature and its flow.

Of these two great types of religion, of theology, of philosophy, the one which, in seeking its home in God, follows in the way just indicated the via negativa, is commonly called Mysticism. To it the nature of God is altogether beyond the categories of our intelligence; the vision of God, which is the light of the soul, is altogether above the ways and activities of our understanding; the rest in God, which is the blessedness of the soul, is altogether apart from the ordinary forms of our experience. Hence the name is quite appropriate. The true, the real, the One,-words cannot utter it nor thought conceive it; how, then, shall the man who seeks it describe himself to the ordinary intelligence? and how shall the ordinary intelligence express its judgment concerning him? Obviously there is but one way. $\mathrm{He}$, whether as he attempts to describe himself to it, or as it judges him, is a Mystic; and his way of life is Mysticism. The other tendency, when formulated as a philosophy, is known historically as Idealism. Its first world-historical master was Plato; from one of his great words the name itself is taken. As a view of the world, it was in part explicitly wrought out by him, in part made possible by him to later men of thought who worked, on the one hand, with more powerful categories and therefore with greater opportunities for selfconsistency, but on the other hand with less of inspiration, less of political and moral and religious passion. But Idealism, in this greater sense of the name, ${ }^{1}$ the modern world has had almost to conquer anew for itself. And he who made the reconquest possible,

1 As distinct from the Sensationalism of the English School, which also, because it is a "way of ideas" (in the sense of that word so unhappily used by John Locke) bas been called Idealism. 


\section{INTRODUCTORY}

though he did his work stumblingly and with all possible awkwardness, was Immanuel Kant.

This, then, is the first great division-and the most radical of all possible divisions-within the "church catholic" of philosophy. It is the extreme and complete opposition of the via negativa to that positive or synthetic method which insists that the true universal is at once the home and the explanation of the particulars, and which, therefore, when it has gained a vision of God, seeks to use that vision as the light which gives a true vision of the world. But this first division is not all; there is a second and lesser to be considered-one within Idealism. For the via negativa, where it does not secure that full triumph which (as at once a metaphysic and a way of life) is Mysticism, is sometimes able to cross over into the field of its opponent and secure a partial victory there. These are the cases where it cannot win men away from believing that the forms of reason express the nature of reality - that ultimate reality is perfect reason. But it does lead them to believe that you must separate pure reason from sensation and sense-experience, and then accept that pure reason alone as expressing the nature of reality. So that you have reality as a world of abstract pure reason, and pure reason in man apprehending it; and then you somehow have another world, the senseworld, and corresponding to it, man's sense-experience. And the true way of life is to renounce this lower world and all its ways, and to live only in that upper world.-This way of thinking may, for convenience of reference, be called Abstract Idealism; in distinction from it, the fully-developed type may be called Concrete Idealism-Hegel called it Absolute Idealism.

We have, then, to sum up, a twofold opposition of the great tendencies which we have been considering: first, their extreme opposition, giving us Mysticism and Idealism; secondly, their lesser opposition within the field of Idealism, giving us Abstract and Concrete Idealism. $^{1}$

1 When the distinction between these two types of philosophy and of religion is stated -and not only stated, but insisted upon-a very old question is likely to recur in a new form: Of what value is the distinction between the inner kingdom of philosophy and its borderland contentions, if that inner kingdom itself is rent apart by divisions of the most 
It is with this central and catholic region of philosophy, and with this twofold opposition of fundamental tendencies within it, that the following papers are in the main concerned. Most of them were written as separate studies; a fact which gives to each its own angle of approach, and involves, also, a certain amount of repetition. But they had a common purpose $;^{1}$ and when taken together have still a certain unity of plan, which may be indicated as follows.-The first two essays deal with the main antithesis itself, that between Idealism and Mysticism:- the first outlining, in simple form, and with reference to the life of our own day, the Idealistic position; while the second, in the historical discussion of what is there called Spinoza's "first metaphysic," traces the development of Mysticism. The remaining papers are studies in the history of Idealism, with special reference to the conflict of tendencies just described-the lesser conflict within Idealism, the greater between Idealism and Mysticism. The history is studied, not consecutively, but by turning to those great masters in ancient and mediæval thought in whom the forces that operate throughout the whole history are seen working with special clearness and intensity. In Plato is seen, for instance, the

fundamental kind? The doubt implied in such a question is, however, not justified; its unfairness can be shown-if it is allowable to ride a parable so hard-by turning once more to the comparison suggested earlier in the text. In the country there spoken of, the observer would soon have become aware of the existence of political parties. And as he looked upon the "fell incensed points" of their stubborn opposition, he might easily be tempted to say that the division between these parties was a far more fundamental one than that between citizens within and hardy barbarians without. And yet, in one most important respect, he would be wrong. For, no matter how radical the opposition of those parties, their members have after all the most important things of life in common ; they have a common speech, a common literature, common arts and education, a common religion-in one word, a common citizenship. The two parties are kindred to each other in a sense in which neither of them is kindred to that race of other blood that troubles the marches. And so here. Mysticism and Idealism are certainly as far apart as any types of philosophy or of religion can possibly be. But they agree in this: they know that the quest for the unity of existence and the quest for the true end and home of the soul are one and the same quest. Out of one and the same impulse proceed their effort after the intellectual apprehension of reality, and their effort, whether by ordinary or extraordinary experience, after the union of the soul with that reality.-Of course, the other side of the matter should not be forgotten. Barbarian and citizen, though without a common citizenship, have a common human nature; it lies within the potentialities of the barbarian's soul to become a citizen. So too, the Materialist or the Agtostic need only do justice to himself, and to the intellectual impulses already at work within him, to become an Idealist.

1 See Preface, p. vii. 


\section{IN'TRODUCTORY}

founding of Idealism as a systematic view of the world and of life. Then, when Greek thought, as one of the constituent elements of the mind of the church, had gone out into the wide world, the strife, or rather the combination, of Idealism with Mysticism is seen in Erigena; and the struggle between the two types of Idealism in St. Thomas. 
THE STUDY OF NATURE AND THE VISION OF GOD 


\section{THE STUDY OF NATURE AND THE VISION OF GOD.}

I.

Among the leaders of the English people in the nineteenth century there was one strangely devoid of the qualities and habits that we have grown accustomed to look for in a modern leader of modern men, and strangely out of accord with what the world regards as the genius of England. He was no captain of industry. He was the head of no princely merchant house. He was not a statesman; not a jurist; not one of the proconsuls of England, who establish her peace abroad in seats of ancient anarchy. He had no part in the labours of commerce, of war, of civil administration, by which Britain has done for parts of the modern world what Rome, with more continuous but more selfish energies, did for the whole of the ancient. From all these, the circles in which the leaders of England habitually move and the works at which they habitually labour, he turned deliberately and resolutely away. He made no quest of any sort after personal popularity. His voice was not heard in the streets; and when, from quiet places and chosen retreats, he spoke to the people of England, it was with warning and grave rebuke. Every word revealed a great gulf: on one side that solitary man; on the other, the customary life, the habitual thoughts, the characteristic activities, of his race. And in the presence of that gulf there came to Cardinal Newman's lips no single syllable of concession or of compromise.

Once, indeed, he had been in more intimate contact with English life and English thought and English institutions. Virtually, though not in name, he had been the leader of the chivalry of the Church of England in its battle with modern Liberalism; and had guided the first steps of that ecclesiastical revolution which has exercised upon the life of the great body of Englishmen an influence more widely form- 


\section{THE STUDY OF NATURE}

ative than they themselves know. But those days were now done. That leadership had been laid aside, and for ever. $\mathrm{He}$ had withdrawn from the noises of the world, and had sat him down in the quiet of an institution, itself in its very nature repugnant to the temper of England and alien to her settled thoughts. It seemed as if his influence upon the men of England were shattered for ever and by his own act. But what really came to pass was that that influence gradually took on a new life. It became more impalpable, less obtrusive, less noticeable; became something which few journalists would have remembered in enumerating the "forces of the day." But it became profounder, instinct with a power more truly essential and therefore more abiding. And it became so, because it became more broadly and simply human, more free from party interests and party accidents, more deeply rooted in the elementary material of life. The change in the character of the influence was due to a change which had come to the man himself who exercised it. A great division had passed out of his life. True, there were still difficulties for him. The policy of the Roman Curia in the days of Pius might grieve him deeply. But it could never shatter the very foundations of his life, as once the attitude and the decisions of the Anglican bishops had done. In spite of all difficulties the fact remained that the muchtried spirit had found its home. Equably and strongly it moved henceforth on its way, like some star which at its true altitude and in its appointed and established orbit sweeps steadily forward " without haste and without rest." In that deep assurance of soul Newman turned, as was natural, more and more to the things that are truly catholic; more and more to the things that do not belong to parties and do not pass away with parties; more and more to the things that, being eternal, are, in the words used a moment ago, broadly and simply human. It is true, he remained an uncompromising advocate of the Roman view of the church and the Roman interpretation of history. But-though he himself would indignantly have repudiated the distinction-his influence as such an advocate came to be the least important part of his influence; his deepest power upon his generation was not that which he exerted as a prophet of the specifically Roman ideal in its conflict with the spirit of the time and with the 


\section{AND THE VISION OF GOD}

spirit of England. His true significance as a leader and benefactor of the English race came more and more to lie, not in any party advocacy, but in the fact that, in an age devoted to material prosperity and to the objects and interests of a materialised life, he, with no particle of submission to the spirit of the age, was a pilgrim of eternity and a prophet of eternity.

And this came to be recognised by the men of clearest eyes in England; specially by one sane and wise critic of life who was separated by the whole diameter of human thought from Newman's political and ecclesiastical views, but had long had his finger upon the pulse of England and was grateful for every spiritual benefaction to her stubborn race. "There are deaths yet to come," wrote the late Richard Holt Hutton in the Spectator when Newman died, "which will agitate the English world more than Cardinal Newman's; but there has been none, and will be none, so far as I know, that will leave the world that really knew him with so keen a sense of deprivation, of a white star extinguished, of a sign vanished, of an age impoverished, of a grace withdrawn. To many, and to many who are not Roman Catholics, it will seem the nearest approach in their own experience to what the death of the Apostle John must have been to the Church of the Fathers, when the closing words of his epistle, 'Little children, keep yourselves from idols,' were still ringing in their ears. . . . Though he served and was at rest, the mere knowledge that he was living in the quiet Oratory at Edgbaston helped men to realise that the spiritual world is even more real than the material world, and that in that lonely, austere, and yet gracious figure, God had made a sign to Great Britain that the great purpose of life is a purpose to which this life hardly more than introduces us."

But it is best of all through his own words that we shall understand him. The remarkable description of his own "special Father and Patron," St. Philip Neri, with which he brings to a close his Lectures upon the Idea of a University, is really a revelation of himself. "He lived"- - so the great words run-_" in an age as traitorous to the interests of Catholicism as any that preceded it, or can follow it. He lived at a time when pride mounted high, and the senses held rule; a time when kings and nobles never had more of 


\section{THE STUDY OF NATURE}

state and homage, and never less of personal responsibility and peril; when mediæval winter was receding, and the summer sun of civilisation was bringing into leaf and flower a thousand forms of luxurious enjoyment; when a new world of thought and beauty had opened upon the human mind, in the discovery of the treasures of classic literature and art. He saw the great and gifted, dazzled by the Enchantress, and drinking in the magic of her song; he saw the high and wise, the student and the artist, painting, and poetry, and sculpture, and music, and architecture, drawn within her range, and circling round the abyss: he saw heathen forms mounting thence, and forming in the thick air:-all this he saw, and he perceived that the mischief was to be met, not with argument, not with science, not with protests and warnings, not by the recluse or the preacher, but by means of the great counter-fascination of purity and truth. And so he contemplated as the idea of his mission, not the propagation of the faith, nor the exposition of doctrine, nor the catechetical schools; whatever was exact and systematic pleased him not; he put from him monastic rule and authoritative speech, as David refused the armour of his king. No; he would be but an ordinary individual priest as others: and his weapons should be but unaffected humility and unpretending love. All he did was to be done by the light, and fervour, and convincing eloquence of his personal character and his easy conversation. He came to the Eternal City and he sat himself down there, and his home and his family gradually grew up around him, by the spontaneous accession of materials from without. He did not so much seek his own as draw them to him. He sat in his small room, and they in their gay worldly dresses, the rich and the well-born, as well as the simple and the illiterate, crowded into it. In the mid-heats of summer, in the frosts of winter, still was he in that low and narrow cell at San Girolamo, reading the hearts of those who came to him, and curing their souls' maladies by the very touch of his hand. It was a vision of the Magi worshipping the infant Saviour, so pure and innocent, so sweet and beautiful was he; and so loyal and so dear to the gracious Virgin Mother. And they who came remained gazing and listening, till at length, first one and then another threw off their bravery, and took 


\section{AND THE .VISION OF GOD}

his poor cassock and girdle instead: or, if they kept it, it was to put haircloth under it, or to take on them a rule of life, while to the world they looked as before."

Such was St. Philip; and such, with a touch of lofty personal distinction unknown to Philip, was Cardinal Newman. But such character and such influence come to no man by accident. Newman in the Oratory was what he was, because of what his own inner heart had been while he was still an Anglican. And what that was we have earlier words of his own to show us. In his last days as an Anglican, when the pain was heavy upon him of his approaching separation from the friends of his youth and from the Church which he loved and from the University which had been his home, ${ }^{1}$ the words, "Man goeth forth unto his work and to his labour until the evening," seem to have been often in his mind. Twice he preached from them; and each sermon was a revelation of the inner and supreme principle of his own life.

" "Blessed are they," - so ran the conclusion of the first" "Blessed are they that do His commandments, that they may have right to the tree of life, and may enter in through the gates into the city.' Blessed will they be then, and only they, who with the Apostle have ever had on their lips and in their hearts the question, 'Lord, what wilt thou have me to do?' whose soul 'hath broken out for the very fervent desire that it hath alway unto His judgments'; who have 'made haste and prolonged not the time to keep His commandments'; who have not waited to be hired, nor run uncertainly, nor beaten the air, nor taken darkness for light and light for darkness, nor contented themselves with knowing what is right, nor taken comfort in feeling what is good, nor prided themselves in their privileges, but set themselves vigorously to do God's will.

"Let us turn from shadows of all kinds-shadows of sense, or shadows of argument and disputation, or shadows addressed to our imagination and tastes. Let us attempt, through God's grace, to advance and sanctify the inner man. We cannot be wrong here. Whatever is right, whatever is wrong, in this perplexing world, we

1 " Trinity had never been unkind to me. There used to be much snap-dragon growing on the walls opposite my freshman's rooms there, and I had for years taken it as the emblem of my own perpetual residence even unto death in my University."-A pologia, p. 237. 


\section{THE STUDY OF NATURE}

must be right in 'doing justly, in loving mercy, in walking humbly with our God,' in denying our wills, in ruling our tongues, in softening and sweetening our tempers, in mortifying our lusts; in learning patience, meekness, purity, forgiveness of injuries and continuance in well-doing."

The second was preached just after his resignation of the living of St. Mary's. He himself, and what life meant for him-both stand revealed in the form which his sorrow took as he uttered what was really his farewell to all that had been dear to him upon the earth; to the Church of England, to his University, to his friends.- " $O$ mother of saints! O school of the wise! O nurse of the heroic! of whom went forth, in whom have dwelt, memorable names of old, to spread the truth abroad, or to cherish and illustrate it at home! 0 thou from whom surrounding nations lit their lamps! O virgin of Israel! wherefore dost thou now sit on the ground and keep silence, like one of the foolish women who were without oil on the coming of the Bridegroom? Where is now the ruler in Sion, and the doctor in the temple, and the ascetic on Carmel, and the herald in the wilderness, and the preacher in the market-place? . . . O my mother, whence is this unto thee, that thou hast good things poured upon thee and canst not keep them, and bearest children, yet darest not own them? Why hast thou not the skill to use their services, nor the heart to rejoice in their love? How is it that whatever is generous in purpose, and tender or deep in devotion, thy flower and thy promise, falls from thy bosom and finds no home within thine arms? Who hath put this note upon thee to have ' a miscarrying womb and dry breasts,' to be strange unto thine own flesh, and thine eye cruel towards thy little ones? Thine own offspring, the fruit of thy womb, who would toil for thee, thou dost gaze upon with fear as though a portent, or thou dost loathe as an offence-at best thou dost but endure, as if they had no claim but on thy patience, self-possession, and vigilance, to be rid of them as easily as thou mayst. Thou makest them 'stand all the day idle' as the very condition of thy bearing with them; or thou biddest them to be gone where they will be more welcome; or thou sellest them for nought to the stranger that passes by. 


\section{AND THE VISION OF GOD}

"And, 0 my brethren, 0 kind and affectionate hearts, 0 loving friends, should you know any one whose lot it has been, by writing or by word of mouth, in some degree to help you thus to act; if he has ever told you what you knew about yourselves or what you did not know; has read to you your wants or feelings, and comforted you by the very reading; has made you feel that there was a higher life than this daily one, and a brighter world than that you see; or encouraged you, or sobered you, or opened a way to the inquiring, or soothed the perplexed; if what he has said or done has ever made you take interest in him, and feel well inclined towards him; remember such a one in time to come, though you hear him not, and pray for him, that in all things he may know God's will, and at all times he may be ready to fulfil it."

A little earlier than Newman-in the great and troubled days, fateful for the whole of humanity, which ushered in the century to which Newman belonged-there had stood among the leaders of England another man, whose life moved in another air than Newman's, but in that other air had followed a strangely parallel course. In early manhood he too had undergone a struggle that shook him to the centre of his being, but at the same time unchained and aroused the mighty powers that were sleeping in him-a struggle in which he had mingled his fate with causes and institutions that go beyond the individual and take in the world. And when his soul had found its peace, he too had taken up his dwelling apart from the noises of the world; not, however, in a cloistral society, but in the company of still lakes and whispering woodland and solemn mountains, above him the alternate gloom and glory of the English sky and round about him the dalesmen's homes and the dalesmen's life. He too, through quiet years, had held like Newman high counsel with his own soul and had lifted up his heart to the powers that inhabit eternity; nay, in this he had gone beyond Newman; for he held counsel with nature also, and made his communion with her a means toward-or rather, a form of-communion with the eternal. And he too had spoken to the men of his generation; had spoken with a voice that in authority, in loftiness, in austerity, was equal to 


\section{THE STUDY OF NATURE}

Newman's own, and far surpassed Newman's in the catholicity of elementary and simple human interest, and in the timeless and ageless power of beauty. True, if you had met him face to face he would not have made such conquest of you as Newman habitually made of all who met him-unless, indeed, you were one of the few that without allurement of external charm can be won to a mighty spirit by its own native greatness. Newman's unfailing distinction, his luminous ease, his unerring sense of fitness, his refined and winning charm, his personal attractiveness, the splendour of his gentleness and the splendour of his austerity-what trace of these was there, or what equivalent for them, in that conversation which (save with Coleridge and one or two others) was no medium of expression either for the peace or for the passion of the intense and brooding soul of Wordsworth? And yet this gaunt and rugged man, with the "severe, worn pressure of thought about his temples, a fire in his eye (as if he saw something in objects more than the outward appearance), an intense, high, narrow forehead, a Roman nose, cheeks furrowed by strong purpose and feeling "- this gaunt and rugged man is perhaps the greatest name in the spiritual history of the English race in the nineteenth century. He did that supreme thing which from the beginning of the world until now few men have done: he looked upon the world and upon the life of man with absolute directness and clearness of gaze. The abstractness of the special sciences, the passions of sectarian theology, the limitations which the spirit of the time is able to force upon men-it was as if these things simply were not, when Wordsworth, strong in his solitude at the heart of things, and immovable by the anger of his age, turned his eyes upon man, and upon man's soul, and upon the facts and conditions of human life, and expressed that which he saw in a poetry which fulfilled his own great and most accurate definition and was "the breath and finer spirit of all knowledge-the impassioned expression which is in the countenance of all Science."

For Wordsworth's attempt was something quite other than to dream about nature, and to weave beautiful fancies around certain of its more winning aspects, and in those dreams and fancies to find a refuge from life or a solace for life. He sought, in the most 


\section{AND THE VISION OF GOD}

genuine sense of the term, to know nature; sought to penetrate to its real character and to grasp its ultimate meaning. This he sought to do by long watching and resolute thought; by sympathetic vision; by that contemplation which is a "revealing agency"; by a communion with nature which was like the friendship of a human heart with a human heart or the companionship of a spirit with a spirit. With a combination of meditation and perception, unparalleled in the history of human insight save by Plato-meditation resolute to the point of stubbornness in its perseverance and laboriousness, perception that with the unclouded directness of intuition penetrated to the inner nature of its object-he looked upon nature and looked upon life; and, looking, saw God in man, and saw nature as the form of a spirit kindred in character to the spirit which is man, and friendly to man in the great purposes of his life. And so, in Wordsworth's eyes, man's life, in its ordinary and daily course, in its elemental duties and charities and delights, in its natural relationships and natural surroundings, took on beauty and sacredness:took on the tenderest beauty and the deepest sacredness that God can give or the universe contain. And this beauty and sacredness of the ordinary life, of the ordinary duties and charities of life, of the ordinary natural surroundings of life, Wordsworth felt not merely for himself. He was able to make others feel it. He had (though not continuously, nor without startling variations in degree) that gift which to such high and severe natures is not always given-the gift of artistic beauty, at times in its absolutely highest order of elementary tenderness and elementary simplicity. So that he was able to cast about our ordinary life, and about the nature which is its earthly home, the supreme consecration of poetic light. And this in a way peculiarly his own: not with that lavish prodigality of the poetic imagination which at one stroke puts the object that it beautifies out of touch with our ordinary thought and beyond the horizon of our daily life; but with a "stern spiritual frugality"2 which at

1 F. W. H. Myers, Wordsworth, p. 131. Compare the whole chapter, pp. 124-153 ; and chapters IV.-VI. in Mr. Walter Raleigh's admirable volume (Wordsworth: London, 1903).

2 R. H. Hutton, Literary Essays (Macmillan, 1896), p. 91. 


\section{THE STUDY OF NATURE}

once beautifies and sanctifies its object, and yet leaves that object a genuine and integral part of our human life upon the human earth. ${ }^{1}$

These two men stand, then, each in his own way, as the representatives of one great principle-that a divine presence is the reality of the world, and that the consciousness of that presence is the supreme illumination for a man's soul.

"Each in his own way," I have said. And indeed, while that truth toward which they turn is one, no two men upon the earth could well be more different in the way in which they apprehend it, or in the quarters from which they turn their faces toward it. For the ways by which the soul enters into union with greater or with ultimate truth are many; and among those many ways are two which stand radically opposed. If, for instance, you would be face to face with the heavenly splendour of the dawn, you may go out into the free fields, where all the dewdrops are lustrous for very purity and in the absolute stillness of early morning the great trees stand in their solitary and monumental peace unroused to the tumult of the day. There you may take your stand, and there you may front the heavenly glory, and there, looking upon it, you may know yourself for a part of it, and may recognise that a city greater than Siena is opening to you her heart and in speech not alien to your own is declaring to you once more your citizenship in her. That you may do. But you may do something very different. You may have come to distrust yourself utterly and hopelessly; perhaps because others taught you that it is right to do so; perhaps because of long pain and long failure. And hence you may never have dared-or never have learned-to go about in the world with the open heart and the seeing eye and the undaunted step of a son in his father's house. Rather you have withdrawn from the world and have submitted yourself to an authority greater than yourself; and when morning

1 Wordsworth's poetry was "not properly an augury, but an interpretation. It led man up to the recognition of his own greatness, as universalised by communion with nature and intercourse with his kind. It was conversant, not with subtleties of the imagination, but with the great, the obvious, the habitual, with the common earth, the universa! sky, the waters rolling evermore, the abiding social powers that lift man out of his animal self, and render him 'magnanimous to correspond with heaven'; with these restored to the ancient glory that belongs to them in their intelligible relations, but from which the prone and poring gaze of a false philosophy had during a century of conceit been diverted." (T. H. Green, Works, Vol. III., p. 120.) 


\section{AND THE VISION OF GOD}

comes it is only through the gateway or the deep window of some monastic enclosure that you can turn your eyes eastward. And the unyielding outline of that cloistral stone it is that then determines and defines what part of that heavenly glory, and how much of it, you shall see.

The former way of viewing the nature which is in man and in the material order was Wordsworth's. That, in fact, to the man who looks with intelligent eyes upon the spiritual history of mankind, is what the name "Wordsworth" stands for. From the beginning until now, he is the supreme instance of it among the races that speak English; if not among all the races of the world. But Newman's method was the other. Himself as an individual he had distrusted; especially had distrusted the power of his own individual intellect to reach ultimate truth. And yet there was in him an imperious demand for the very truth which he distrusted his own power of attaining, and for the guidance which such truth alone can give to life. From the beginning it had been his prayer and his passionate desire that his soul might be with the saints; not standing alone in mere individuality, nor left to its own caprices and mistakes, nor wasted in some blind alley of the world's affairs, nor lost in some wandering by-path of mistaken thoughts; but with the saints-with the men by whose labours the central path in the history of man has been driven through the midst of the years. And slowly there had dawned upon him that mighty vision which to such a man has the power of absolute compulsion. An institution august with solemnities of ancient prayer, august with a thousand sanctities and a thousand heroic memories, august with mighty names innumerable and mighty deeds, the home of saints and the guardian of belief, drew him to herself and subdued to herself all his heart and made him in humility and obedience her son. To her, with a sense of gladness and of rest, he gave himself and gave the keeping of his life. And so he found rest; and having found rest was able to do, more positively and constructively than before, the work which it lay in him to do for the men of his day.

But the price was a dear one; and it was paid still more by those who sat at his feet than by himself. For in precisely that side of 


\section{THE STUDY OF NATURE}

his work which most deeply concerned the men of England, his true strength was veiled. The things that he himself had learned so thoroughly, and that all men need to learn-things universal, essential, elemental, catholic-he preferred to base upon the authority of an earthly dogma and an earthly institution; and to mingle with them, in obedience to that same authority, things not universal, not essential, not elemental, and therefore not catholic. So that those who hear him have always to separate that in his words which belongs to essential eternity from that which belongs to the party interest of a magnificent but sectarian priesthood.

And to this so radical difference between the two men in their method of apprehending truth, there corresponded a difference in their manner of expressing it. Wordsworth, having " seen into the life of things" by that sort of companionship with them which passes over into a comprehension of their inner and ultimate reality, was, in his expression of what he had thus seen, a poet. And that in the true and most strict sense of the word. He was not a man who wrought out a system of philosophy or of theology, and then gave to it an alien garb of more or less successful rhythmic utterance. He was not even a man who lived-to use Mr. Stopford Brooke's fine metaphor -in that "mingled region" of poetry where "its waves and currents near the coast receive the deep streams of religious and philosophic thought." His voyage and his home were upon its "central and lonely deep," where poetry is poetry and nothing else. Hence when Wordsworth is here spoken of as among the greatest of the spiritual leaders of the English race, the Wordsworth that is meant is Wordsworth the poet. He was a captain of the spirit, was among the greatest of all captains of the spirit, because he exercised, and in exercising, supremely a certain supreme function-the function of the sacred poet. But Newman, meeting God in the inner heart, was as characteristically and as inevitably a prophet, in the strictest sense of that great word. To impress-I had almost said, to forcehis consciousness of a divine presence and a divine commandment upon the men of his generation, making no slightest particle of concession either to their practical or to their theoretical materialism,

1 Hibbert Journal, No. 1 (October, 1902), p. 62. 


\section{AND THE VISION OF GOD}

was the supreme business of his life. Resolutely he set the whole of life in the light of ultimate eternity. Unflinchingly he insisted that every interest, every ambition, every affection, every dominant fashion and accepted tendency, should answer at that bar for its life. Authoritatively, uncompromisingly, in season and out of season, that voice and that pen, and, above all, that solitary and devoted life, declared that we men are living our lives in a divine presence; and that that divine presence is the one essential reality with which in our lives we have to do, and obedience to its purpose and commandment the one business of life which can claim in any sense to be of . importance.

Different enough, then, the two men were:-different in individual habit and personal presence; different in the region and climate of their minds; different in their ways, as of approaching and apprehending, so also of expressing, truth. But here our main concern is not with these differences but with that in which they agreed; with their consciousness of a divine presence and of that presence as the ultimate reality of the world and of our life.

\section{II.}

Once, among the men from whom we moderns draw our blood and our speech, and in whose places we now stand, such a consciousness, under the more limited of the two forms just described, dominated life. $\dot{A}$ "consciousness of a divine presence and of that presence as the uiltimate reality of the world and of our life," and a consequent consciousness of the supremacy of spiritual interests, were central and determinative among the forces that made the mediæval world what it was. So far as the religious spirit of their time lived in them, mediæval men habitually looked upon themselves as members of an eternal order and citizens of an eternal kingdom. They worked " as seeing One who is invisible," and as "not being disobedient to a heavenly vision." They remembered that in order to live we must die, and that in every department of life the divine ordinance is the cross with its principle of self-renunciation and of living " not to be 


\section{THE STUDY OF NATURE}

ministered unto, but to minister." They lived "under the power of the world to come;" and if this present world showed itself to their understanding as the foe of that world, they did not shrink from the separation, but made strong their souls, and denied the present world and all its love, and walked in it as strangers and pilgrims. This was in their hearts; and in the great confession of their day, the book De Imitatione Christi, it spoke itself into words for ever; but it was no mere maxim for meditation and confession-it was a genuine principle of unity of life. For that generation as truly as any other "went forth unto its work and to its labour until the evening":nay, more truly, for the middle age stands as in all the history of the world pre-eminently the age of great workmen; not of great machines, nor of great financial combinations standing over against sullen and reluctant labourers, but of great workmen and of the delight in craftsmanship which great workmen can feel. And that which was in their hearts and in their confession-that habitual remembrance of God and craving to be at one with Him, that incessant and insistent vision of a world to come and of a divine order which earthly eyes cannot apprehend but which is manifest in the crosswas also in their action and achievement. They worked greatly in the field of the intellect; and the effort was to gather all science into one thoroughly-articulated knowledge of God, which in part should illuminate, but still more should rebuke, the ways of this present world. They worked with equal greatness in the field of art; and there too-though it is specially in art that the-human soul rejoices in its own powers and in the exercise of them for their own sake- they were under the banner of the world to come. For when they painted, it was the judgment, the heaven, the hell, which give to this life its awful significance; or it was the saints in their conflict with the world; or our Lord submitting Himself to the helplessness of infancy, or undergoing the death of the cross, or rising in that resurrection which showed another world triumphant over the ways of this. Or when they built-and they were for the sustained spiritual passion that animated their work the greatest builders in the history of the world-their building culminated in houses of prayer which lift themselves almost out of connexion with the 


\section{AND THE VISION OF GOD}

earth and express in the most stately of all man's languages the majesty of heavenly things and the upward movement of the soul in prayer toward that majesty. Even when they sang, romance and folk-song - the/delight of the young in earthly love, and the illumination of this present life by the naive imagination-were felt to stand half-unconsecrated without the gate, while within the singing was that of men whose vigil was for another country and whose love was set upon a farther shore. And as were the works so were the men. If a man arose, at once to embody the ideals of the age and to dominate its higher imagination, it was Bernard controlling Europe from that lowly cell where as the proper business of his life he sought the mystic vision of God; or it was Francis, with his humility, his selfdenial, his pity and tenderness and loving ministration to the poor, his canticle of praise to our Lord for "our sister, the death of the body" and for "all those who forgive one another for His love's sake." Pilgrims of eternity, encamped for one troubled night upon this shore-such the men over whom the spirit of that age had power felt themselves to be. The "lyrical cry" of their life was that of Israel ; but the cry wrung from solitary hearts in Israel by the afflictions of the righteous and the measureless prosperity of the wicked and the desperation and disaster of Israel's struggle for racial existence, had become in them a settled conviction and an habitual temper:

Thou shalt guide me with thy counsel,

And afterward receive me to glory.

Whom have $I$ in heaven but thee?

And there is none upon earth that I desire beside thee.

My flesh and my heart faileth :

But God is the strength of my heart, and my portion for ever.

God was the strength of their heart; God and the world to come were the realities that filled their thought. And precisely from this arose what we have just had to see: though the world was not their home, yet, so far as they looked upon it at all, they were worthy workmen in its affairs. The fact that they viewed the world from a point high above it, gave them alike in thought and in action a double strength: gave them, first, the loftiness of mind which arises out of a great devotion-and the devotion of the unworldly to their 


\section{THE STUDY OF NATURE}

causes is, as the inner soul of action, a power unspeakably greater than ambition; gave them, secondly, the spirit of comprehensive unity. Not only did they seek the unity, under a divine idea, of the intellectual outlook upon life; they sought a still greater goal-the unity, in a divine order, of the social organisation of life. The conscious or unconscious aspiration after that twofold unity was, to their mind its inner power, to their society the highest of its organising principles.

In this way-a way narrow but profound and masterful-a consciousness of the supremacy of the spirit and of spiritual interests once dominated life. And of the men who bore that consciousness we are the children; we stand in the succession of their blood and of their labour. But we view the world and live our life in a temper radically different from theirs. The men amongst us who view life in a way similar to theirs, or in a way kindred to theirs but broader, are not the representative men, the men whose spirit is an expression and epitome of a temper which clearly or unclearly is common to us all-the men who are to our day what Bernard or Francis was to his. It is true (now that the immediate personal conflicts are over) that we are very willing to listen to such men as Newman; still more willing to listen to such men as Wordsworth. Indeed we listen to them with an urbanity, a completeness of intellectual toleration, which in mediæval days one at least of them would have looked for in vain. We give them, in fact, everything they ask-except the one supreme thing which they demand most of all. We appreciate the excellence of their literary workmanship. We do justice to the height of their characters. We are grateful to them for the grace and the dignity which they have added to our life, and for the honour accruing from their work to the English tongue. We listen gladly to the one as the bearer of a poetic vision. We hearken respectfully to the other as the prophet of what, with the forbearing courtesy of well-bred men but with hearts untouched, we call mystic piety. Only let us view them as a specially noble sort of dreamers, weaving around the hard core of the actual reality of things a garment of fancy and high emotion which adorns and dignifies its surface but can make no claim to 


\section{AND THE VISION OF GOD}

express its true nature:- - then they are quite intelligible to us; indeed, with our sense of the bareness and hardness of our life, not only intelligible but very estimable. But as soon as we are told that their words are the plain and simple truth about our world, and about the meaning of our life in it, and about our actual everyday affairs; as soon as we are told that their valuation of the things we modern men are all striving for is the true valuation:- -at that instant we feel a great gulf fixed between us and them; a gulf so deep as to preclude either mutual understanding or mutual sympathy or a common aim in life.

So radical is the difference in temper between us and the mediæval men whose children we are. But a glance at the history which lies between us and them will show that the change was inevitable. For in their position there lay a double difficulty. They forgot certain great works of God which cannot be forgotten without shattering soon or late the man or the age or the institution that forgets them. First, they forgot the natural world. With all their understanding of the supremacy of the spirit and of spiritual interests, they did not understand that nature also teaches that supremacy, and is herself, to those who know her as she is, and are able to use her wisely, a means toward it. And because their position thus did injustice to nature and the natural order, the time came when the man of science, the poet, and the ordinary man, had, each in his own way, to rebel against it. Secondly, save to rebuke it, they almost forgot the natural soul of man. But that soul contains powers which soon or late must come to their right: powers of affection and of passion; artistic powers and powers of the systematic intellect; and that power of initiative which makes man, like the God from whom he comes, in his own order a creator and founder. To a few of these capacities of the natural soul, the mediæval system, it is true, gave magnificent scope-specially in the art of building; but most of them it scorned or repressed; and, by its tendency to change faith from an energy of the divinely illuminated individual soul into a systematic creed laid down by an authoritative institution, it sinned so deeply against human nature as to drive men at last into the modern position that the only illumination worth having is that of a free man, that even 


\section{THE STUDY OF NATURE}

a heavenly vision is not to be received unless it come as to a free spirit.

So that the man who studies history, however much he love that age of great workmen and of great workmanship and of great souls whose citizenship was in heaven, has to insist that the age could not continue. And, at first sight, the student of history seems able to go still farther; seems able to point out the way in which the advance should have been made. It should have been by growth, not by rebellion and revolution. The principle should not have been thrown away because it had been practised too narrowly. With the great achievement of mediæval men a complete break should not have been made. Their light should not have been treated as though it were merely and simply darkness; rather it should have been retained in its integrity but freed from its limitations. Men should live still as citizens of the world to come, but recognising that of the world to come the present world is an organic part. The divine idea should still be seen as the one important reality in human life; but it should be remembered that the stage in the realisation of that idea at which we men can directly and sincerely labour, is the one found in the causes and activities which make up the life of a normal man in this present world - the life of the good neighbour, good citizen, good churchman. Or, to put all this in one word, the true way of advance from the medirval position was to pass from the type of insight and of spiritual consciousness represented in modern form by Newman to that represented by Wordsworth.

But whatever the reason be, the history of the universe-so far, at any rate, as the history of man on this earth is a part of it and an index to its nature-does not go on by any such direct and easy method. The God from whom we come shows Himself in His work a Lord of Hosts. He develops the powers of His creatures and the life of His universe by calling forth the mighty opposites that He has implanted in the natures of things, so that each develops its truth and its power against the other, until at last the very stress and pain of the conflict lead men to that still wider truth in which justice is done to the incomplete truth which each side had and was developing. Fortunately or unfortunately, it is as true in the kingdom of the 


\section{AND THE VISION OF GOD}

spirit as it is in the physical order that plain daylight is a thing most complex. All the great kinds of light (if one may so speak) have to be discovered and set in their places, by hard labour-sometimes by hard fighting and many wounds and wanderings-before that day can come in which all the types of light will blend in the illumination which alone in the full sense of the word can be called truth.

And so it was that the spiritual splendour which in the mediæval dawn of our history gleamed through cloud and storm and over the brute earth, was not, in the direct fashion mentioned an instant ago, to deepen into a more inclusive day. Age after age was to come, each in its own way a very antithesis to the mediæval. First came the Renaissance. Men flung themselves with absolute delight upon the resources of this present life, and for the first time after many centuries lived as masters and lords of this present world. New worlds they discovered in themselves; new worlds across the sea; and in the products of ancient culture, the most alluring of all their new worlds. They loved the world, and the sorrow in their words was because upon all the objects of their delight they found it written that the world and the fashion of it pass away. Augustine's mourning was that he had lived in the things of the world so long and had found God so late: "I have loved Thee late, Thou Beauty so old and so new; I have loved Thee late!" But the deep undernote of lament in the greater Renaissance writings was because the glorious children of the earth, in the midst of their life found themselves to be in death. And yet their love of the world was no ignoble passion; their delight in the things of the world had in it such a magnificence of mind that it was a religion rather than a slavery; and to-day, it is the better men and not the worse who in hidden places of their souls have still the banner of the Renaissance flying. But already, unknown to the men of the Renaissance, profounder and more terrific forces than their view of life comprehended, were "toiling in the gloom," and soon throughout Europe, first in religion and then in political affairs, the trumpets were calling to war. In the end that war exhausted or destroyed nearly all that was noble in the forces which had given rise to it, and left for the close of the seventeenth 


\section{THE STUDY OF NATURE}

century and the earlier part of the eighteenth, a world degraded and desolate, a world that slowly regained the solid comforts of life, and acquired a certain hard and polished culture, but in which, probably to a greater extent than in any other Western century since Rome fell, the visible and established elements of society, churches and theologians, rulers and ruled, forgot God. And then came our own day. It dawned at Paris; dawned in blood, and with mighty passionspassions social and political and one might almost say religious, which spread their energy throughout the world; but it proved in the end, and not unnaturally, to be the day of the scientific intellect. That intellect had long been held in check: alike in the age of passionate devotion to the humanities, and in the age of war, and in the hard age that had no place either for the enthusiasms of the pure intellect or for the devotion of the mind to nature. But now at last it came to its own; or rather, as is usual in such cases, to more than its own. Without the lofty Renaissance passion, without the special Renaissance delight in life, free also from much of the eighteenth-century hardness of spirit, it set itself to master the world. As an investigating intellect, it made itself at home with the facts and laws of nature; as a contriving intelligence, it reduced the powers of nature to practical uses-bringing in at last the day of which Bacon prophesied with such large magnificence of speech, but which probably he would view with a certain lordly contempt, if, with Elizabethan memories, he were suddenly to come to life in it.

Such an intervening history places more than the mere lapse of time between us and the mediæval men who won from chaos, and established with settled forms and laws, that living and thinking which it is now our business to carry on. When we compare our mind, and the world of our life, with their world and their mind, we may sum up the loss and gain in two broad statements. First, while both in spirit and in skill of hand we are poorer workmen than the mediæval men were, yet we have a mastery of this present world which they had not. We have explored, as they could not, the possibilities of the present life, and have entered, both intellectually and practically, into possession of the two great kingdoms which it contains-on the one side, the kingdom of nature with its powers; on 


\section{AND THE VISION OF GOD}

the other, the kingdom of humane culture and of the higher passions and affections. Other men might use the materials which the world affords in building great houses of prayer to testify of another world and by their very majesty to shame into nothingness the vanities of this; we have found that those materials can be used in erecting and adorning mansions for the present habitation of our own souls. And, having such houses for our souls, we cannot regard ourselves, while upon the earth, as strangers and sojourners. Rather we feel ourselves to be citizens of no mean city; a city which we have placed on sure foundations by taking as the servants of our life the powers of nature, and as the tutors of our minds the laws of nature.

But secondly, in this very conquest of the world we have to a great extent become lost in the world. We have made the earth our own; but have become too much confined to it. It goes, indeed, without saying, that the latter does not follow logically from the former. For the discovery of the greatness of the present life is absolutely no reason for ceasing to live the great present life under the power of some still greater life to come. The connexion, as already has been indicated, is one not of logic in the narrower sense, but of that greater logic which is history. The Renaissance revolt contributed to it in one way; the Thirty Years' War in another; the eighteenth century in still another. And we ourselves managed badly; we flung ourselves so eagerly into the new fields and the new life that our hands became subdued to what they were working in. But here it is with the fact, rather than with the fault, that we are concerned. And the fact may be considered as moving in two spheres, a narrower and a wider.

The narrower sphere is that of thought. Here the new situation consists in a changed view of the field of knowledge. The things that we regard as certain-the things that are the objects of reliable and indisputable insight-are things strictly of this world. We have the knowledge of nature; that is assured and established science. Some of us feel that this assured science permits something farther; something which, if any one so chooses, may be called a knowledge 


\section{THE STUDY OF NATURE}

of God, but would more properly be called a faith or a hope. Others of us believe that our science of nature does not permit such farther "knowledge" or "faith." But what we all seem agreed upon is that the two are essentially different things; the knowledge of nature and the knowledge of God cannot be regarded as essentially akin, as two stages in one growing insight, or as two levels in one and the same structure.

In this shattering of the former unity of science, and this limitation of knowledge in the strict sense of the term to one of the fragments, the leading influence has been the modern study of nature. But we must notice with special care how the exertion of such an influence has been rendered possible. It has been made possible, not from one side but from two: from the side of the men of natural science themselves; and from the side of the theological leaders of the church.

First, from the side of the men of science. The movement of thought by which many of these passed from their knowledge of nature to a materialistic or agnostic view of the world has already been described. ${ }^{1}$ It is sufficient here to indicate the result. This was the placing before modern men of a teaching about life and the world, which was not new, indeed, but which now took on a new power. For it was inculcated now by men deservedly of great influence; men of wide knowledge, of disciplined mind, of undoubted honesty, the leaders in the most striking and most evidently successful of the intellectual labours of modern times. Moreover the movement of thought by which it was now reached (though really involving a great oversight) was so direct that the resultant view seemed to be based immediately upon established and indisputable science. That the physical process is continuous and its sum of energy constant; that it must lead our planet soon or late to a dead eternity in which self-conscious life can have no footing:- these (so that resultant view may be stated) are the things that are beyond doubt, and upon them anything which is to be a sober and reliable wisdom for the conduct of life must base itself. Hence it is no longer open to us to regard ourselves as other than beings of the present world; nor 


\section{AND THE VISION OF GOD}

to regard as other than, visionary any view which makes " the great purpose of life" to be "a purpose to which this life hardly more than introduces us." If you would know the true character and meaning and destiny of human life, there is but one way to gain the knowledge: you must consider the total system of which that life is a part; that is to say, you must consider the system of natural facts, out of which it arises and in which it is lived. If you ask: But was it not those very facts that Wordsworth considered? the answer comes in very direct words: "His views were a poet's fancies; fancies clad in beauty, but none the less fancies. And the dreams of a poet, or the visions of hearts that cling to life and to love, cannot take precedence of established and disinterested knowledge. Such knowledge it is that we have in the sciences of nature, and it affords no ground for visions and hopes that go beyond this present life. Modern science, in one word, has shattered old religion."

But as was indicated above, the fact that the modern scientific movement has contributed to the materialisation of thought and of life has been made possible, not only from the side of the men of science, but also from the side of the theological leaders of the church. And the latter is the greater and the sadder story. Theology, upon the older conception of it, included all knowledge. It meant the whole of science brought to the unity of a supreme and ultimate principle; brought to unity in and as a knowledge of God. Hence the theologians were bound by their own conception of their task to be catholic-minded, to be hospitable to all the orders of science. 'The notion of theology as a single special science standing among the other special sciences, and at war with some of them, was a notion which-if they could have formed it-they would have rejected as monstrous. On the contrary, it was only by taking all the sciences as their "parish," and considering each as part of the knowledge of God, that they could fulfil their function. Hence-inevitable as was their failure to complete their science-they were qualified by the very nature of their attempt to perform one great service for humanity. If there came an intellectual movement-whether the recovery of Aristotelian treatises or the founding of new sciences-bringing with it a body of knowledge new but convincing to the age, they, as theo- 


\section{THE STUDY OF NATURE}

logians, were the men at once obliged and qualified to receive it, to interpret it, and to set it in its place in the one knowledge of God.

It was precisely such a work of interpretation that the modern world needed from its theologians. There had come a great, a triumphantly successful, scientific movement, giving us a better acquaintance than ever before with that work of God which is the natural world. The duty of theology was to receive with catholicity of mind that new body of science, to penetrate to its real significance, and so to give it its place in the one body of man's knowledge of God. To have received in that way the sciences of nature, to have viewed sub specie aeternitatis their work, and so to have given to them their "divine interpretation"-this, and this alone, would have given us what we needed. For what we needed was not polemic, but a point of view from which we could look upon both sides of the conflict, and see into the ultimate harmony in one rational world of the great truths which seemed to have come from radically different worlds and to be in death-struggle with each other.

That we needed; and that the theology of Albert or of Thomas, recognising its high prerogative of being the guide of the human race in those spiritual crises which the revolutions of time bring forth, would have striven with all its might to give. But the greater principles and greater procedures of those masters had long ceased to obtain; their conception of theology, with its demand for a comprehensive view of the world and consequently for a catholic attitude toward all sciences that deal with the world, had long been forgotten; or if remembered, was remembered with grave dislike. "Systematic theology," as it was when the minds were being formed of those who are now doing the world's work, would have been remarkable to St. Thomas chiefly for its limitations, for its absent problems and absent provinces; he would have shuddered alike ${ }_{2}$ at the narrowness of its scope and at its dread of the greater enginery of the intellect. It is impossible, indeed, to enter here into any lengthy comparison of the new conception and place of theology with the old. But the essential nature of the difference may be very briefly indicated:

Just as, upon the highest conception of the matter, religion arises from the practical passion after God, so theology arises from the 


\section{AND THE VISION OF GOD}

intellectual passion after God. But the knowledge of God means all knowledge; to know God means also to know the world; unless you are a Mystic, there is no such thing for you as a knowledge of God which is not also science of the world. And if you urge that with you theology is less proud, and renounces so high an endeavour; that the one thing you are intent upon is the salvation of the soul; that your one function as a theologian is to cast intellectual light upon the course of that salvation and thus, even though it be indirectly, to assist in it:-your new definition of your science still does not free you from the obligation to walk in its greater way. For what is the salvation of the soul? That question you can answer only by raising another: What is the soul? What the salvation of the soul is, depends on what the soul itself is; unless you know what the soul is, you do not know either what its salvation properly consists in, or how wide the scope of that salvation is. But if you would know what the soul is, you are brought by a double road to a demand for the knowledge of God. First, to know what the soul is, you must know the true nature of the world, of which the soul is a part, and in whose order and conditions the soul lives its life and has its place to fill; and thus to know the world you must know God whose character is the ultimate character of the world, and whose purpose is the ultimate law of its order. Secondly, and directly, if you would know what the soul is, you must apprehend the nature of its source, that is, of God, and the nature of the end for which He made it, the attaining of which is its salvation. So that theology, in order to be a wisdom of salvation, must be a wisdom of the soul, a wisdom of the world, a wisdom of God. And the scientific or constructive order of these should be noted. Whether the first and impelling interest of the theologian is in the soul or in God, that which is first in the order of scientific construction is God. In anything which is to be a "system" of theology, the knowledge of God-that is to say, the theistic view of the world-must stand as the prius of the knowledge of salvation. Unless theology is to be blind, unless it is to build its upper structure without giving any attention to its foundations, it must begin by working out, with all the completeness possible to such an intellect as man's, the theistic view of the world; and in its sub- 


\section{THE STUDY OF NATURE}

sequent work, soteriology or eschatology, it must take up no positions inconsistent with the principles of that theistic view. Whichever interest, then, sets us upon the work of theology, with whichever conception of it we approach it, we are brought, first or last, to the fact that, in order to discharge any of its functions, it must be that highest and final science which is at once a wisdom of God and of the worldof God as realising His purpose in and through the history of the world; of the world as at once the scene and the process of a divine activity.

It is in this regard that theology upon the mediæval conception of it, and modern professional theology, are essentially diverse. The view which mediæval theologians took of their work approximated to that just described. Hence they were profoundly in earnest about the theistic view of the world. They may not have succeeded-perhaps no man can succeed-in working out such a view consistently; but at any rate the attempt was made as the first and fundamental labour of theology, and to it was devoted the whole energy of one of the greatest of intellectual generations. By one and the same intention their theology was a wisdom of God and a wisdom of the universe. But modern systematic theology, at the time when the sciences of nature were beginning to dominate the intellectual field, was distinguished by nothing more than by a great timidity about the theistic view of the world; nothing was farther from its thoughts than to be a wisdom of the universe. How anything so contrary to nature as this-for theology afraid of theism is like mathematics afraid of being mathematical - could come to be, is a long story the main outlines of which are easily traceable by the student but cannot except in a brief reference be noted here. In broad terms, the change was simply a part of the general and inevitable breaking up of the mediæval unity of thought and life. Theology became separated, on the one side from metaphysic and from the metaphysical mind, on the other from the special sciences. And that meant that it lost from both sides its capacity for discharging its older function-its function of receiving scientific knowledge and giving it its divine interpretation. And then too, this tendency of theology to become a smaller thing both in its intellectual soul and in its outward extent, was fostered 


\section{AND THE VISION OF GOD.}

by another aspect of modern life-the dividedness of the church. 'Theology no longer had "centre everywhere." In some of the churches "systematic theology" fell into the background altogether, the institution preferring to stand in its own living and continuous strength. While, where it did survive, it was usually with an unhappy procedure. Instead of seeking first the knowledge of God, and then basing upon that its account of salvation, it came more and more to have as its centre of gravity, came more and more to be "built around," a certain forensic scheme of soteriology. That scheme, as a matter of historical fact, was not fairly drawn from any of the chief theological sources. It had almost no connexion with the actual mind of Jesus as shown in the Evangelia. It did no justice to St. Paul's great philosophy of the world and of history, which centres in the views (1) that the supreme principle of the order of the universe is the eternal Christ-in Christ the universe consists-and (2) that God's attitude toward man, as revealed in Christ, is one of grace,, not of that requirement of legal satisfaction for wrong done which is the exact opposite of grace. It stood at an unspeakable remove from St. John's view of Jesus-that He is the Word in whom the character of the Father and His attitude toward men and the world stand revealed; that, in other words, $\mathrm{He}$ came into the world not to change the Father's attitude toward men, but came because of it and to reveal it. Rather it had arisen under the influence of Roman Law and of the Roman legal and political mind (with Jewish law in the background), and had been fostered in the West by ideas and procedures belonging to the primitive jurisprudence of the Germanic peoples. But though so largely heathen in its origin, it had come to be regarded as Christian because it was so tenaciously held by Christians, and because it could be supported by a careful selection of passages from St. Paul. For the men in question, this forensic scheme of soteriology was theology; and anything beyond it they were inclined to dread. Of necessity they called themselves theists; but, while they could be severe upon those who were not called by that name, there was nothing from which they shrank with a deeper repugnance than the bringing out into clear light of the meaning and the implications of the theistic view of the world. But precisely that theistic view it was 


\section{THE STUDY OF NATURE}

which, seriously held and seriously developed, would have enabled them to receive the new knowledge of nature and to make it at home as part of the knowledge of God. For what the intelligent theist knows is precisely this: that just because God dwells in eternity, $\mathrm{He}$ is the informing spirit, the home and the goal, of the world that now is; that of Him the natural order is a visible Word, and therefore the study of nature the study of a part of his thought; that in the actual history of yesterday and to-day and to-morrow $\mathrm{He}$ is at work realising an eternal purpose, and through a thousand channels is calling upon men to work along with $\mathrm{Him}$; that $\mathrm{He}$ is the nearest of all things to each man's heart, seeking to win each man's heart to Himself and to become its supreme principle and central energythe Father, in a thousand ways and by a thousand appeals seeking to win the hearts of His prodigal children back to Himself and to engage them in the great works at which He Himself is working. Such theism, however, they could not enter upon, much less develop into clear articulation as a view of nature and of history. It lay too far from that with which their minds were filled-the view of the universe as a court of law; of the divine administration of the universe as consisting in the transactions and expedients of such a court; of the death of Jesus as central in those transactions, greatest among those expedients.

As was said before, the question is one of fact, not one of fault. Perhaps (though few nowadays care to believe it) it is well for us, when we study history, to carry our hearts-our humanity, not our partisanship-back with us to the bygone struggles, and mourn for the mistakes of the dead as for our own sins. But however that be, one thing is clear: we ought, in dealing with the past, to turn as much as possible from the easy work of fault-finding to the more difficult but more honourable task of seeking to trace a wisdom of the ages at work through all the apparent confusion and wrong. And this is specially important in dealing with the present point. For, as was noted a moment ago, the modern disintegration of theology was part of the general modern disintegration of the mediæval unity of thought and of life. And that deep and far-reaching disintegration may in the end have a good result; the "hidden wisdom of the 


\section{AND THE VISION OF GOD}

world," in whose service all the generations stand-even those which "know it not"-may be, or rather must be, at work in it. Indeed, some at least of the signs of this have long been visible. Many of the sundered factors, forced to stand alone-each erected into a solitary kingdom, and compelled to find a whole world in itself in order to live at all-have entered into deeper possession of themselves and of their own resources; science, for instance, ceasing for a time to look upon God, has entered with a new freedom and a new fulness upon the mastery of nature; while literature, with new powers of sympathy and passion and insight, has recovered and has glorified whole regions of the soul that long had lain in neglect. And of this enriching and deepening of life in its estranged and severed aspects, the result is that if a new integration of thought and of life-a new intellectual and social integration-should in any future be achieved, it would be one vastly richer than the mediæval. All those powers of human nature-industrial, commercial, political, literary, scientific, humanitarian-that have swung away from religion, will be seen to have swung out in a great circle which at last will bring man back, with wider life and larger heart, to God. Such a synthesis, indeed, does seem to be drawing nearer on the intellectual side; being aided, from the one direction, by the Idealistic interpretation of science; and from the other direction, by the historical study of the Bible-a study which, by setting the mind of Christ in its place of supremacy, makes it possible for virtually every genuine power of human nature and of the world to reconcile itself to God and find its fitting place and its true being in the one world-work of God. But on the social side, if one confine one's self to actual achievement as distinct from beliefs and ideals, one has to say that the struggle is as yet more in evidence than the synthesis; in some regards, indeed, though happily not in all, the gulfs between class and class, interest and interest, seem, if possible, to be growing deeper.

But we must return to the special point here in question. Whether the fact be regarded with hope and therefore resolutely accepted and even welcomed, or whether it be judged with grief and anger, the fact itself remains that when, through the triumphant advance of the scientific point of view, the time of intellectual crisis came to modern 


\section{THE STUDY OF NATURE}

men, the theologians had neither the requisite equipment of ideas, nor the requisite intellectual vision of God, to enable them to perform the function which at such a time they owe the world. It was not in them to receive the modern scientific movement, to view its results sub specie quadam aeternitatis, and thus to give them, so far as is possible to the human intellect, their "divine interpretation." In this situation some of us were able to trust stubbornly to our own hearts and to the religion from which our fathers had drawn their heroic strength; and so were able to steer straight on through the intellectual chaos. Others of us, who could not rest in a division of the heart from the intelligence, obeyed an inward call and made a journey-perilous and beneficent, as all true journeys are-to far-off schools; and there; from the Kantians or from Plato, gained the insights to which those who taught us with authority ought to have brought us. But those are exceptional cases. The important thing is to notice the effect upon the general modern mind. It came to this: that when men of science, whose. work compelled us to respect them, drew from their indisputable acquaintance with nature the conclusion that the religious view of man and of life and of the world could no longer stand, we were in a position where we could not fairly resist them; in a sense their battle was won before they began the attack. For, in so far as the most of us had a reasoned view of the world at all, a reasoned outlook upon the nature and structure of the cosmos in which we live, a reasoned apprehension of the character of that continuity which runs like fate throngh its entire history and all its processes, it was precisely from those men of science that we had received it. Who else was there to give it to us? And that was not all. We not only received it from them, but we received it in.their sense, and from the point of view of their sciences; for there was no higher interpretation which showed a genuinely scientific spirit and could therefore be convincing to an age of scientific mind. ${ }^{1}$

1 The wisdom which leads on the ages is greater than our dreams, and we may trust that even in its sternness it is kindlier than our fairest imaginations; else it might be permissible for a man to dream how well it would have been for us all, if, in the day when the sciences of nature were coming forward, those who guided the thought of the church had been men of Origen's spirit. 


\section{AND THE VISION OF GOD}

$(\beta)$

But if in the realm of thought there has come to be a gulf between the science that knows the earth and the faith that looks to heaven, much more does the separation of earth and heaven find place in the practical conduct of life. There is to be found the true "modern Materialism." We have become materialised in our ambitions and ideals; the ultimate and controlling purpose of life is too little the promotion of a good which is eternal and common to all, too much the attaining of that material good which passes rapidly away and the possession of which by one man frequently involves the exclusion of others from it. To state the case more broadly, we have fallen into bondage to what older men were wont to call "the spirit of the world"-the spirit which always is individualistic and selfish, and usually is earthly and mercenary. It was pointed out above that mediæval religion, precisely because it set men high above the earth, gave them a spirit of comprehensive unity in dealing with the things of the earth; led them to the idea of the unity, in a divine order, of the whole social organisation of life. But the spirit of the world exerts just the opposite influence. It begins by setting each inan upon the search after his own individual good; and ends by leaving him incapable of devoting himself to any good save that which is earthly and material.

One of the instances of this dominance of practical materialism and of the spirit of the world-the instance that must stand here as representative of all the rest-is perhaps the saddest thing in modern life. Because the leaders of modern industrial society make material interests supreme in their lives, great masses of other men are compelled to make material considerations, in their most elementary and most brutal form, supreme in their lives. For while the modern manner of living is more humane than the mediæval, yet, in the modern industrial organisation of society, the gaining of the livelihood itself is, for whole classes of the people, a harder, a more precarious, in many cases a more absolutely hopeless, matter than it was in mediæval society, and precisely for that reason claims all the energies of life, leaving none for higher things. 


\section{THE STUDY OF NATURE}

Such the modern position has come to be. In the realm of thought, indeed, as already has been indicated, the last quarter of a century has brought a great improvement. We are looking with wiser eyes upon the sciences of nature-because we ourselves have become more scientific; and because, in growing more scientific, we have found that the spirit of Christ and the spirit of science go naturally together, like love and light. In that sense, the first intensity of the intellectual conflict is past. And one of the signs of this calls for special notice. Of the ways in which the mind of the church has become more scientific, and in becoming so has apprehended the kinship of the spirit of Christ and the spirit of science, the most important (leaving aside the general fact of an increasing spaciousness in thought and therefore in intellectual sympathy) lies in the growth of that scientific study known as Biblical Theology. Biblical Theology arose when the scientific spirit, by its own natural and legitimate advance, entered into the church and took possession of the key to the whole theological situation-namely, of the sources. And this means that it is from the scientific spirit that modern theology has received its greatest benefaction-the restoration to it of Christ as He actually was, and of His mind as it actually was manifested. It is a thing full of hope for both the church and the world that in theology the dominance of invented systems with their proof-texts-systems which were the expressions and the symbols of schools, and sects, and parties, or even of individuals - is slowly passing away, and the mind of Jesus, as gathered from His recorded teaching and action, and from the Christian consciousness, is more and more becoming determinative. ${ }^{1}$

But while the first intensity of the conflict is thus past on the intellectual side, the conflict itself is not yet over. Not only for many individual minds, thinking honestly their own thoughts and seeking as best they can the light necessary to life, but also for many influential groups of teachers and of learners, the two sides are still in antithesis. On the one side religion, not by any commendation of the theologians

1 In all such discussions concerning theology and the mind which is desirable as the mind of the church, it is of course to be remembered that, important as theology is, it is not the supreme thing; the chosen dwelling-place of the spirit of Christ always has been, always will be, in pure and simple hearts which love Him and live in that love. 


\section{AND THE VISION OF GOD}

but by intrinsic power of its own, makes still the appeal which twice at least has mastered the world; and the former wisdom, the wisdom mediæval and Platonic, whose knowledge was of the soul and whose vision was of the home of the soul, finds still to be its prophets men over whom the spirit of the time has no dominion, a Wordsworth or a Newman. But on the other side the scientific mind and the science which is its work stand over against religion and over against the older wisdom as unreconciled powers, equally resolute, equally masterful, and to many minds greater in power of immediate and convincing verification. It is a great conflict; and yet it is the lesser half of the spiritual struggle into which every modern man is born; over against it stands its greater counterpart, the conflict in the realm of practice, where, in opposition to the spirit of the cross, there stand the spirit of the world, and that far-reaching materialisation of life which the spirit of the world, working with mightier instruments than ever before, has effected.

\section{III.}

Men who are in earnest about their citizenship in the world, when they find themselves in the thick of the struggle just referred to, soon learn one thing: the only power that can overcome the spirit of the world is something as practical as itself; is the spirit which has scen and chosen the better part, and lives in the world "not to be ministered unto, but to minister "- the spirit of those who have looked upon their Lord and serve Him by more than speech. So that the only value that can be ascribed to discussion and argument is a sec- $v^{\prime}$ ondary value. But that value, though secondary, is by no means slight. For we must remember that thought and practice do not stand apart; they are related as soul and body. And in particular, the practical spirit of religion needs clear eyes. There is no religion-no religion such as can change the world-without vision; to choose the better part men must look beyond the earth and apprehend heavenly realities. And though such apprehension need not be distinctly intellectual in form, yet, in at least some of the members of every society, it ought to rise to the form of that penetrating and 


\section{THE STUDY OF NATURE}

systematic thought which is able to look upon the world and assure itself what the reality of the world actually is-whether it is a materialistic or a spiritual order, whether it is good, or simply indifferent to good, or an eternal dualism of good and evil. And what has already been said will show that in our day the problem for such thought-the problem for "philosophy"- -has been brought to a very pointed form: What is the ultimate meaning for life and religion of $>$ our scientific knowledge of nature?

To the apparent conflict, then, between the science which knows nature and the religion which has as its inner impulse a vision of God, we must now turn. The first thing to be noticed is that such a conflict is scarcely a case of truth against falsehood. It is rather a case of divided knowledge and divided insight; a case of truth against truth. Men placed in such circumstances are sure to have recourse to many "working solutions"; to the faith that dares, or to the stubborn manliness that clings to ancient morality or religion in spite of intellectual confusion. These are measures of war, inevitable upon an obscure and troubled battlefield; and the men who adopt them often serve greatly their day and society. But the fact remains that such attitudes are not adequate solutions. And what is necessary to such an adequate solution is equally clear. In a division of the sort now in question, where one side is based upon a certain order of science, the only solution which can be finally satisfactory consists in more or higher science; consists, that is to say, in gaining by a genuinely scientific method a point of view high enough to give a comprehensive outlook over both the warring sides and over the territory upon which their warfare is waged. For it is unjust to take your stand within one side, as within a closed circle, and then from within that closed circle to pass judgment upon positions which lie outside and are based upon a different order of principles. That is to say, it is unjust to take one's stand within the "natural science consciousness" and in its name summarily to brush aside the consciousness of which Wordsworth is in one way, and Newman in another way, a type. And it is equally unjust to call for the flat supersession of the scientific consciousness, on the ground that some other consciousness-poetic, moral, religious-has the right of way. Neither 


\section{AND THE VISION OF GOD}

of these procedures constitutes a solution of the problem. In neither can a thoughtful and honest mind rest permanently or take up its ultimate abode. The first is the hasty-occasionally the contemptuous-evasion of the problem by refusing to recognise the existence and weight of one of the two sides; and such a procedure contradicts that very spirit of science in the name of which it is undertaken. The second is the makeshift of spiritual desperation. ${ }^{1}$ By this it is not meant that poetic intuition and religious vision have no place in man's life. On the contrary, his ordinary life in its whole range of daily thought and daily work, is a pitiable thing without them. And even in conflicts such as are here in question, men have more than once or twice done great and genuine service by taking their stand upon poetic intuition and religious vision, and in their name defying both the scientific and the commercial consciousness. How this can be so, we shall a little farther on be in better position to see. In the meantime, what we have to notice is that such an attitude is not a permanent solution. To settle down permanently into, such an attitude-worse still, to speak authoritatively to the thinking men of your generation and have nothing but such an attitude to commend to them-is simply to set one closed circle against another closed circle; is simply to solidify the opposed ranks in their opposition. What is required for a permanent solution is that the critical and $r$ disinterested reason, walking in the way of science and in the spirit of science, should strive forward toward its goal; that is to say, toward a view of the world as one. Such a view, if only it could be gained (and-as we shall see-it can be gained) would enable us to do both of the things which are necessary to an adequate solution. It would enable us, first, to recognise whatever truth there may be on each side; nay, to do more, to give that truth a deeper meaning and a fuller interpretation by setting it in its place in a system of wider truth. And how much this latter consideration means may be seen by remembering one thing: if each side has its truth, if both of the opposed sides are really elements in one truth and one life, each having

1 And when employed as a method of theology, is something worse; is a makeshift of desperation on the part of men who ought to be the masters and kings of the whole intellectual situation, but have allowed themselves to be driven to bay in a corner of their own realm. 


\section{THE STUDY OF NATURE}

its own great place and great right, then we may be sure that each can also contribute to the power and breadth of the other; for great truths are not self-contained; they answer to one another and contribute to one another. Secondly, it would enable us to understand the limitations under which each of the sides apprehended and envisaged its own truth-limitations which shut each side away from the other and made each accuse the other of blindness or even of falsehood. And understanding these limitations means (as Hegel so steadily insisted) a very great deal more than merely stating the fact of their existence. It means understanding how they came to be; how they are inevitably bound up with certain special points of view, so that the men who live habitually at these points of view are subject to the corresponding limitations of outlook upon the world. Such a method would enable us to recognise truth wherever there is truth to be recognised; and not merely to recognise it, but (what is more difficult) to do justice to it. In particular it would enable us to leave the established laws and principles of natural and physical science standing in their full inner integrity and at the same time to take them up as harmonious elements in a system of truth wider than themselves; a system in whose wider light their ultimate significance for life and for the meaning of life would become manifest. And that would put us in position to correct precisely the order of mistakes with which we are here concerned; not mistakes in matters of fact (a sort of mistakes which scientific men are not given to making) ; but mistakes in interpretation, mistakes in applying the principles and the points of view of the special sciences to life and to the problem of the meaning of life.

Indeed, the demand for such a solution might be stated wholly from the side of science itself. For it is the presupposition of all science and of all endeavour after science-it is the presupposition of every step in every scientific investigation-that the world is one, a single system of interrelated facts; and that therefore knowledge is one, a single system of related insights. Hence the ultimate truth about any one part of the world, or about the scientific principles employed in the study of it, becomes manifest only from the centre; nnly from a point of view which commands the whole field and which 


\section{AND THE VISION OF GOD}

is gained, not so much by the study of fact after fact in detail as by apprehending the inner nature of the total system. And it is precisely when truths appear to conflict that it is most important to remember this; most important of all when the conflict is such as that between the "natural science consciousness" and the religious consciousness, where the two sides appear to stand so far apart, and yet each is so deeply rooted in existing reality.

The task, then, which faces the man who has taken into his heart that for which Wordsworth and Newman stand, and who at the same time finds himself compelled whether he will or no to be an intellectual citizen of the modern world, may be summed up thus.-First he has to attempt to comprehend the ultimate significance for the $v$ problem of the meaning of life, of the modern scientific knowledge of nature. Secondly, to do this he must seek to gain a point of view from which, in some genuine sense of the words, the world can be seen as one, life viewed as a whole, facts comprehended sub specie quadam aeternitatis. Thirdly, the quest of that point of view must $\checkmark$ be carried on in a genuinely scientific temper. Rebuke of science; evasion of the demands of the scientific spirit; the "flat supersession of the scientific consciousness" in the name of the religious consciousness; the attempt to follow some by-path or "short cut" upon which one hopes to get past the scientific position without the danger of being taken prisoner :-all these are $a b$ initio forbidden. ${ }^{1}$ In a word,

1 One of these attempts to "get past the scientific position" is so fundamentally bad as to deserve special mention-the endeavour to justify belief in God by seeking to find gaps in the continuity of nature. It is true that a God thus made manifest-made manifest not by the greatness and harmony of nature, not by its abiding law and continuous order, but by its rents and gaps-would be no worthy object of religious devotion. But that is only the beginning of the matter. Once you shatter the continuity of nature, you shatter :more than Materialism. You shatter the possibility of all science whatever. You open up the gulf of universal scepticism, and Materialism disappears in it, it is true, but along with it disappear Theism and theology and the rational basis for every sort of religion except two, between which men will continue to choose according to their individual dispositions-Stoicism (as a practical temper, not as a philosophy) and Epicureanism.

In a word, in insisting upon the continuity of nature, men of science have been better theologians than the theologians themselves. If God exists at all, He is the God of all nature and of every natural law. There are no gaps in His workmanship, no breaches of continuity in His activity. All nature is an activity of His, and every natural law a principle of that activity. If the theologians would be true to theology, what they have to do is to protest, not against the principle of continuity, but against too narrow a reading of it and too narrow an application of it to reality. The principle of continuity is 


\section{THE STUDY OF NATURE}

the attempt to discover the ultimate significance for life of our knowledge of nature should be carried through with fidelity to the scientific spirit; and the view finally gained of the ultimate meaning of our science of nature should be, in a genuine sense of the words, a farther stage of science itself.

\section{IV.}

But in approaching this task one is approaching no new or purely modern task. To gain insight into the significance, for the problem of the meaning of life, of the fact that man has science of nature; and so to gain that insight that it shall be a farther stage of the same science:-upon this attempt, or upon a greater which includes it, has been directed the longest and most continuous of all the labours of the human mind. Each intellectual era has come to the problem in its own way; in its own way has stated the problem, in its own way attempted the solution; and the struggle upward through inadequate categories has been slow and stubborn. Hence the special pleader or the hasty critic can easily arrange a clever argument for the charge that the imagined insight of each age stands in contradiction to that of the others, and that therefore the whole history establishes nothing. But as a matter of fact that history has the unity which arises from a central and catholic line of development. And the man who is willing, and who is able, by historical study, to repeat that development in his own thinking and live it over again in his own soulthe man who illuminates his soul with the wisdom of the ages, and grows into that illumination as the ages themselves grew into it-is the man who, when the problem here at issue falls upon him, can conduct most intelligently his own wrestle with it, and can best be a guide to others.

For what the great men of thought who in their succession constitute that "central and catholic line" have seen, is precisely that

unworthily treated if it is limited to certain physical and chemical processes. The true field of the principle of continuity is the total history in time, the total evolution, of the universe. And as so viewed, it is simply one way of apprehending the essential rationality of God and of the divine action in nature and in history. In this-and I think only in this-lies the basis for a worthy constructive doctrine of miracle. (See the acute discussion in Mr. Balfour's Foundations of Belief, 1897, p. 316 seq.) 


\section{AND THE VISION OF GOD}

such a farther stage of science as was referred to above is possible. And not only that it is possible, but also that the human intellect must seek after it unless the human intellect is to live in treason against the scientific spirit. They have seen, in the first place, that man's knowledge of the material order implies a greater whole of knowledge, from whose point of view the world is seen as a whole and man's life in its true meaning; and in the second place, that that greater whole of knowledge is a fulfilment of man's knowledge of nature, not a revolt against it, nor a contradiction of it.

The age-long labour in which the "masters of them that know" endeavoured to fulfil the scientific demand which they had thus apprehended, cannot, of course, be described or outlined here. But certain of the outstanding facts of its history, if noted at this point, will enable us to orient ourselves in the courts of philosophy, and to $v$ apprehend the nature of the tradition that has grown up there. ${ }^{1}$

That tradition entered, almost at its beginning, into conscious possession of its own true nature as an effort after the unity of life. For the mind which gave rise to philosophy and science, and presided over the beginnings of their tradition, and informed the construction of their first great monuments, was that of the Greeks; and the graver genius of that race-even while its cities, by divisions without and within, were working out for themselves irremediable ruinsought to rise above the divisions of thought and of practice; sought to see life "steadily," to see it "whole," and to discover, at once for the individual and the state, the true unity of life. That unity the Greek-so far as the deeper genius of Hellas prevailed in him - sought by proportion. He would bring life to unity, not by extirpating all interests save one-driving out religion, for instance, in the name of science, or the good in the name of the beautiful, or the expert in government in the name of democracy-but rather by

1 For the younger student of philosophy, the historical study that does this has, in addition to the value noted earlier in the text, this special value: it puts him in position to make with more intelligence his estimate of the present-day voices that claim his attention. For in this as in every age, some of the writers in philosophy are so related to the traditional development that their own individual strength is at once rooted in and reinforced by the incalculable strength of the central and catholic past; while others, who astonish their day with inventions of their own, represent in philosophy the merely individual and therefore the transient. 


\section{THE STUDY OF NATURE}

giving to each legitimate interest and capability of the soul, its due and proportionate place-primary or secondary, as the case might bein the single system of an harmoniously ordered life. The life which results when a single limited interest, or a single unbridled tendency of human nature, takes complete possession of a human soul and of a human body, he refused to call a human life; and any social order which would make such life inevitable to the various classes of enfranchised citizens he looked upon as essentially vicious. In the state, according to the ideal of it, each citizen was to perform freely and devotedly the function for which nature fitted him; and so the life, on the one hand of the state, on the other of each individual citizen in it, was to reach completeness both of development and of efficiency. Unity of life; completeness of life; and the securing of these by harmonious co-operation of natural powers in which each helps the others by doing with excellence its own work:this was at once his ideal of life and his principle for the organisation of the state.

Furthermore, the Greek mind in its scientific workmanship was thoroughly disinterested. Greek men of science and Greek men of thought were wont to look upon the facts of life and the facts of the world with clear and direct eyes; they saw things just as they are and described them exactly as they found them. The notion that truth-truth in the grave and deep sense of the word-could have ill consequences in the practical life, had no place with them. By the very nature of the mind in them they were free from the vice of doing violence to the scientific conscience in order to conduct special pleadings for ethical and theological positions. Indeed, it is precisely for that reason that the Greek mind has contributed, as to the cause of science, so also, and even more profoundly, to the cause of goodness. $>$ For hostility to science, or even alienation from it, in the interest of morality or religion, is as injurious to these themselves as to science; nay, is even more injurious; for it works them a triple injury. It exposes their fundamental principles to suspicion as fearing the light. It shatters the unity and integrity of life; and incompleteness of life means incompleteness of morality and of religion. And-the deepest injury of all-it steals away from them that which is at once their 


\section{AND THE VISION OF GOD}

eyesight, their interpreter, and their intellectual soul, and thus leaves them to the mercy of the dogmatic and the priestly mind.

These qualities of the Greek spirit made the interpretation of life which it wrought out a thing of supreme value for ever to the men who, for the business of living life, wish to clear their eyes and clear their intelligence. That interpretation took two main forms: a more literary, in the work of the tragedians, who in huge and majestic symbols of ancient legend expressed their sense of the operation in man's life of a necessity greater than man, so that the blind choices, the hasty movements of the individual will, bring in their train inexorable fate-fate clad always in terror, but sometimes dimly seen to the poet's faith to be the form of a great righteousness; and a more scientific, in the work of certain great men of thought who carried farther than the poets the attempt to understand the nature of that necessity, and found it to be eternal, and, in the highest sense of the words, rational and righteous. By singular good fortune to humanity, this latter interpretation came to share, at its culmination in Plato, in one great feature of the former: came to add to its own intrinsic value as a guide of life a manner of expression fitted to win men's hearts. For while Plato had, in its very highest form, the disinterested scientific temper of the Greeks, and their clearness of intellectual vision, he was more than a great scientific intellect contemplating life. He was one of the most human of men. He knew life by walking in its ways, by sharing in its greater struggles, by enduring its greater sorrows. Yet his vision was driven beyond the horizon of this world; alike by the discovery of his intellect and by the demand of his soul for a home truly appropriate to its nature, he was led to contemplate an eternity and a perfection, which are not of this world, though they are the truth of it and the standard for judging all its affairs. And in this ascent of his soul the characteristic genius of his race did not desert him, though its lighter elements were rebuked and fled. He remained a Greek seeking for integrity of life and delighting in the exercise of all the faculties of the soul; an artist, with the artist's instinct for apprehending and expressing beauty; a poet, able to find earthly words for realities unspeakable, and for the things of eternity a voice that passes into 


\section{THE STUDY OF NATURE}

human hearts "with lightning and with music." So that when in Plato the graver spirit of Hellas entered into full and critical possession of itself, and put into words that which it had learned concerning the world and concerning life, the words went forth to later generations clad, in addition to their scientific truth, with a threefold power-that of humanity, that of beauty, that of religious passion.

But though Plato's words were at once the profoundest and the most human of all the words that have been spoken in the schools of philosophy, the two world-ages which followed did not take him as their teacher. The mediæval world, indeed, might have seemed the very world for the reception of Plato. For the men of that world were actually achieving - to them the supreme business of life was to achieve-the very thing which had lain closest of all to Plato's heart, and which he had called for from the Greeks in vain: the subjection of the sensuous world to the supersensuous, the making of the whole order of the state, the whole course of individual education, the whole structure and organisation of society, a " service of the invisible world." But, for one thing, of the corpus of the Platonic writings little beyond the Timaeus was known. For another thing, the dominant party made religion inseparable from the church, and the men who laboured in the task of giving to the world its divine interpretation were churchmen. And these, when they required an intellectual organon for their immense endeavour, found in Aristotle a system remarkably well adapted to their needs. If it had somehow been possible for them to gain a comprehension of Plato as he truly is, they would probably have found him a very troublesome friend. For a spiritual power, incalculable, unfathomable, not to be fettered or led, is a thing which does not commend itself to the typical churchman. And that is precisely what Plato is. For, in the first place, he is always a dialectician; and his dialectic allows your mind no rest except in ultimate and essential eternity. And in the second place, as we shall see later, ${ }^{2}$ although he is not a Mystic, yet Mysticism can be learned from him; and Mysticism makes short work of external organisation, of material symbols, of churchly observances.

1 Windelband, Platon, 3te. Auflage, S. 169.

2 Infra, pp. 214-232. 


\section{AND THE VISION OF GOD}

At the same time, there is in mediæval thought much more Platonism than we usually fancy; partly because the mediæval temper led independently to it; partly because, in choosing Aristotle as their master, the mediæval theologians chose, next to Plato himself, the best Platonist in the world. And if Aristotle did not reach the height of the Platonic temper, his mediæval pupils could contribute that directly from their own hearts.

With the modern world the case has been different. It could know Plato if it would; and from the Renaissance onward it has had many ardent disciples of Plato. But its temper has in the main been un-Platonic; and in its science it began by breaking radically with the past. The world of Descartes and Bacon, in the extremity of its revolt against the mediæval, would have nothing to do with any science but its own; would begin all over again the work of understanding the nature of the world; would fight its scientific battles altogether from its own beginning, altogether in its own fashion. The outcome was remarkable. When one penetrates to the great currents that beneath the troubled surface have driven forward as steadily and as irresistibly as if Necessity herself were in them, ${ }^{1}$ what one finds is an almost exact parallelism with the course of Greek thought. The Eleatic and the Sophist are accurately in their places ; the Eleatic (in Spinoza) with much of the old Parmenidean dignity; the Sophist with almost the old procedure in his scepticism. And at last the specifically modern way of approaching and stating the problem was set by a very un-Hellenic SocratesImmanuel Kant. ${ }^{2}$ His work was that of a pioneer. It furnished

1 As a matter of fact, necessity was in them ; the logical necessity which governs the $V$ dialectic evolution of the categories.

2 Whether as a mere fact of history, or an instance of how the inner wisdom of history, working under the form of dialectic development, enlists the individual in its service, this parallelism between the course of Greek thought and that of modern, is very striking. Both began at the beginning; or rather, Thales actually did, and Descartes tried. Both settled with stubborn resoluteness to the attempt to understand the world from the point of view of the category of substance. With the Greeks this culminated in Par. menides, with the moderns in Spinoza. Finally in each case the lesson was learned (being soundly emphasised by the rise of scepticism-Gorgias and Protagoras and Hume) that an ontology cannot be constructed off-hand; that a trustworthy theory of reality can be gained only through, and in, and as, a theory of knowledge. The learning of this lesson is connected in the one case with the name of Socrates, in the other with that of Kant. And in each case the learning of this lesson meant that philosophy entered auf den sichern Gang der Wissenschaft. With the Greeks Plato and Aristotle followed; with us, the present period, in which every metaphysician who is in the main course of philosophy and not in some eddy or side-stream, proceeds from the point of departure set by Kant. 


\section{THE STUDY OF NATURE}

little more than a beginning. And in Kant's own writings even that beginning was sadly obscured. It was loaded down with masses of alien material and with needless dualisms; and it suffered especially because Kant dropped his own fundamental insight half-way, and so drew from it almost the opposite of its legitimate conclusions. Indeed, something like this was to be expected; for that insight was the gain of Kant's old age, the long-delayed reward of a lifetime in which that acute and penetrating intellect worked through the dogmatic and empirical and sceptical and sentimental philosophies of the day and found rest in none of them. But, under whatever weight of alien and obscuring matter, the beginning was there. And the task set for the modern mind by it has been accepted and pushed resolutely through. The carrying of the Kantian beginning-if you will, of the Kantian suggestion-forward to its legitimate conclusion has been the special task of metaphysic in the period of philosophy in which we now live.

In Germany this was done by a succession of men of thought, the last and greatest of whom was Hegel. Of him it is sufficient to say that each of the great intellectual ages has given to the world an encyclopædic philosopher-a man who, so far as was possible to the human mind, gathered into himself all the science of his day, and interpreted it from the point of view of an insight into the ultimate nature of reality, and so made it in the true sense of the word a system: the Greek age gave Aristotle; the mediæval, Aquinas; the modern, Hegel.

But though Hegel's is the one name that ranks with Aristotle's and with that of Aquinas; and though he has written very deeply upon many of the more capacious minds of the day his own great conviction that God actually is at work in His world, and that the divine reasonableness actually is present in the structure of the universe, in the laws of nature, in the course of history; yet he is likely never to become a great and familiar teacher of the human race, such as Aristotle and Aquinas have been and are and will be. In particular-and this is what specially concerns ourselves-he will never in any direct sense be the great teacher of what for want of some better name we must call Anglo-Saxondom. For one thing, his writings 
are often needlessly obscure and difficult; and the unhappy form in $v$ which it was necessary for his editors to issue a great part of them has not helped the matter. For another thing, there is a feature of his work which is peculiarly distasteful to the "Anglo-Saxon"-or at any rate to the specifically English-intellect: the technical apparatus, useful as it really is, is so enormous that sometimes it smothers the very content for whose expression it was devised; while at other times it carries Hegel, rather than Hegel it-at which times the man of thought appears to be mounted upon a very high horse indeed. ${ }^{1}$

1 At the same time many of us would bring to our work in the world a graver and more comprehensive wisdom if we could avoid one mistake: we let Hegel's high words, his masterful and comprehensive procedure, drive us into rebellion against him and all that he represents; and so we are blinded to the fact that there are things which we need to learn and which his Idealism has to teach.

An example will show what is meant. Lotze and Paulsen, the one in an earlier and more irreconcilable way, the other in a later and more moderate, fought the battle of the steady everyday consciousness against the thoroughgoing procedure and vast results of the "speculative philosophy." But in doing this they lost sight of the fact that the very thing needed in order to give coherence to their own philosophical construction is the Kantian epistemology as clarified and systematised by Hegel. In them philosophy was unnecessarily crippled; not altogether, but to some extent, philosophy in them defeats itself ; in the name of the ordinary consciousness and of everyday interests, of the "solid ground " and of "plain facts," they recoil from precisely those scientific insights which show us what those everyday interests and ordinary facts really are-the body, namely, of an eternal reason, the media through which and in which an eternal purpose is being realised.

But men such as these bring to their criticism of the "speculative philosophy" a fine and high temper. "Sit anima mea cum illo" one has to say of such a man even while arguing against him. But one occasionally meets a very different type of critic: the man who makes it part of his duty to pass in review the "masters of them that know" simply to find a flaw in each and then throw them all aside and return triumphantly within the circle of his own sectarian-or individual-theology. To such a man Hegel is usually the most special of all his bugbears. But with such an attitude the student who in dealing with the world of thought seeks its greater wisdom and its greater virtues-and only he who is such a student to-day is worthy to be a leader of the intellect of the church to-morrow-will have nothing to do. Reverently he will approach the world's masters in science and philosophy; he will keep himself from the ingratitude that in the presence of the great workmen of the intellect seeks only to discover the imperfections of their work; he will endeavour to make his way through transient, and often inappropriate, forms of expression to the inner and abiding meanings, and to do justice to the truths that great men of old reached out after but were not able to grasp clearly and express happily; and so from each one-still more from all of them viewed as forming one great history and one great development-he will carry away for himself a worthy harvest of insight worthily gained.

The fact that in Germany itself there is no "Hegelian school" is often referred to, and various inferences adverse to "Hegelianism" drawn from it. But in the first place the Hegelian view of the world is not dead; it has become part of that intellectual air which we all are breathing, and which withont Hegel would have been a very different and a much poorer thing. And in the second place, one of the facts of German life should be 


\section{THE STUDY OF NATURE}

Hence the most trustworthy of the men of thought who in English-speaking countries have bent to the work of carrying Kant's beginning forward to its conclusion, while they have learned much from Hegel and directly or indirectly are under profound debt to him, are not "Hegelians"; are not followers of Hegel in the strict sense of discipleship. ${ }^{1}$ From the point of departure which Kant set for us all, they have gone forward with the sober caution of their race, and have steadily avoided any such immense technical apparatus

remembered. In Germany the "great, masters"-those upon whom the young men form their minds-are usually living men; you migrate from university to university, look upon their faces, hear them read. The advantages of this are instantly apparent. But it does not seem to be equally well understood that such a state of affairs has at least some disadvantages. These were never better summed up than once by the young man who later became Dr. Pusey: "There is probably no people among whom the mighty dead are so soon forgotten, or the great names of the present day so unduly exalted, as in Germany, and this because the knowledge of the mass of each generation is derived for the most part exclusively from living sources." (See Liddon's Life of Pusey, 1893, Vol. I., p. 230.)

For young students it may not be a mistake to enter into Hegel's system by working backwards; that is to say, by beginning with the Philosophy of History (which as Jowett remarked to Tennyson "is just "the increasing purpose that through the ages runs' buried under a heap of categories") and the Philosophy of Right. Then,-and all the better if with the help of Mr. Baillie's, and Mr. M'Taggart's, valuable exposition and discussion-the Logic can be attempted. Of introductory statements of Hegel's thought and of its significance, the best remains, and is likely long to remain, that by the Master of Balliol. The handbook by Professor Mackintosh couples with attractive points one grave defect. It is described in the preface as a handbook and evidently was intended to be such. But in a handbook one thing is essential : it must be an exposition, an explanation, an interpretation, in the simplest and directest form possible, of the system in hand. To that one purpose all the writer's literary powers and virtues should be subordinate and contributory. But Professor Mackintosh's discussion, while having any number of incidental virtues-it is most interesting and suggestive, full of bright sayings and happy passages-lacks precisely this essential quality of a handbook. One might almost say that so far from being primarily an exposition of Hegel and of the Hegelian view of the world, it is an exposition of its author's own opinions, and a somewhat unfair criticism of Hegel in the light of them. And the treatment is very unequal. At some points (whether in dealing with Hegel or with the British teachers called, not quite fairly, "Hegelians") the author writes like a son of the house describing to the public the objects of a long and intimate knowledge; at others, with a strange hardness and externality, almost (if the comparison may be pardoned) like a stranger who stands outside and throws stones at the windows.

1 With regard to this, Professor Mackintosh, in the handbook referred to in the preceding note, does not act quite as fairly as in this age, when party names mean so unjustly much, is desirable. To call men "Hegelians" who are Hegelians only in the same sense that they are Platonists and Aristotelians, is not an example of Professor Mackintosh's rule (op. cit. p. 86) that "a well-chosen class name is the first step to knowledge." The story of Hegel's influence upon British thought might have been written without the application of a party name to men who lived above party. And the unfairness is all the graver that the name is applied in the face of protests from the men themselves who are chiefly concerned. 


\section{AND THE VISION OF GOD}

as that of Hegel. This has involved, it is true, the loss of much that was possible to him; the great sweep of his system, his vast and orderly outlook upon history, upon nature, upon all the departments of man's life and society. But there has been a corresponding gain; and that no mean one; for the fundamental problems, at any rate, have been treated; and treated with a simplicity, an intellectual severity and self-control, which put the discussion within reach of many to whom Hegel himself is ein 'Buch mit sieben Siegeln.

Among these men there are several toward whom the present writer cherishes an affectionate gratitude which grows deeper with every year that separates him from the days when he sat at their feet. But it is upon the name of a man whose face he has never seen that he desires at this point specially to dwell. The late Pro- $v$ fessor Green had not the special gifts of the men to whom reference has just been made: not the remarkable blending of profundity and subtle keenness which characterises one of them; not that union of philosophic insight with the whole breadth of humane learning which gives charm to all the work of another; not the vast and systematic range of thought which makes a third the representative of philosophy in its true greatness as a rationally articulated view of the world and of life. These things Green had not; for his life was weighted with labour and his day was short. But his life and his teaching had two features which make the mention of his name specially appropriate in the present connexion. In the first place, he cannot fairly be called the prophet of any "school." It is true, he approached the question of the meaning of life from the point which Kant has made inevitable for modern thought. But in the investigation itself, the considerations which he brings forward and the arguments which he employs are elementary, are primary and simple; and just for that reason are fundamental, and hold for all life under all circumstances. So that while in one sense the discussion is Kantian, yet in a still deeper sense to apply party names-Kantian, Neo-Kantian, Hegelian-to it, is as impossible as to apply party names to the first and elementary principles of any great science. And in the second place, while Green was, in life and character, English of the English, and by that character and life spoke with Englishmen heart to heart, 


\section{THE STUDY OF NATURE}

yet there was operative in him precisely the most valuable tendency of the Greek mind-its tendency toward unity and integrity of life. The fragments of writing that he left behind him give, if read intelligently, a systematic outlook upon life-they contain both a system of fundamental principles and an application of these to the understanding of nature and of history. But that is the lesser side of the matter; if he did not, in any finished or technical sense, write a system of philosophy, he lived one. What his biographer has to record is, as Mr. Nettleship so well says," "a fact which has never been common and which is especially rare in England, the fact of a life in which philosophy was reconciled with religion on the one side and politics on the other; the life of a man to whom reason was faith made articulate, and for whom both faith and reason found their highest expression in good citizenship." It is in men such as this that philosophy is most clearly seen doing the work that it ought to do in every age, but specially in an age like our own; for in such men philosophy becomes the philosophic mind, and the philosophic mind leads to a life and a work in which the contending elements and warring truths of the age are seen reconciled and working with united power.

V.

The great argument which thus, from its clear beginnings in Hellas, passed onward through the ages with all those turns and retreats, and yet with that very real continuity of development, cannot be presented in a few pages. Its full meaning can be gathered only by living through, in one's own soul, the long course of the history in which it struggled into possession of its many insights. But a sense of its import can be conveyed, and an indication of its procedure and conclusions given, by a brief outline of its modern form-the form which it has taken in the school of Kant, but which nevertheless is so simple and elementary as to stand above party affiliations. In attempting to draw up such a statement, one of Green's writings is specially useful; the ensuing outline was suggested by, and in places

1 In the Memoir prefixed to Vol. III. of the Collected Works, p. xi. 


\section{AND THE VISION OF GOD}

follows quite closely, the argument worked out with great simplicity $\checkmark$ but also with great thoroughness in the Prolegomena to Ethics.

We must begin with something which, as already has been noticed, ${ }^{1}$ was to the greater masters of philosophy at once a first insight and an impulse to farther insight. In order that our experience of everyday things may be what it actually is, reality must be greater than in our everyday experience it seems to be. ${ }^{2}$ Or, to put this into the narrower and more modern form which exactly meets the problem now before us, the natural and physical sciences, by the very fact of their existence, imply and call for a whole of knowledge wider than themselves. For all science is a tracing out of the relations of the facts and events of the world to one another. The laws of nature which men of science formulate are statements of those abiding relations; and the total system of such relations is the order of the world. But suppose the natural and physical sciences to have fully accomplished their work. There would still remain a relation to be investigated-the relation of all those facts and events to the knowing intelligence. Every thing, every event, every relation, which a man of science investigates, enters by the very fact of being known and investigated into a relation with intelligence-into that organic union with intelligence which from the side of the intelligence itself is called knowledge or science. To say that such a thing as natural and physical science exists, is to say that mind and the world, subject and object, have entered into organic connexion; the knowing intelligence has gone out into the world, has traversed it, penetrated it, made itself at home in it-and in doing so has realised and fulfilled its own nature as intelligence; or putting it in another way, has taken the world, or parts and beginnings of the world, into itself, and that not as a mere outside article drawn into an empty container, but as an organic part of its own structure. This relation everything in the world that is or ever can be an object of scientific investigation, sustains or is capable of sustaining; and to say this, is to say that science must advance to the investigation of the relation in question. For

1 Supra, pp. 54, 55.

2 I have tried to work this out more fully in the paper on Plato, infra, pp. 203-247 (especially pp. 208-214). 


\section{THE STUDY OF NATURE}

if science be the tracing out of the relations which the constituent parts or factors of the world bear to one another, then it is the flattest of treasons against the scientific spirit to say, "We will investigate certain classes of the relations which make up the world's order; but with the relations that fall outside those classes we will have nothing to do." The existence of science is the existence of this relationthis relation of things to intelligence, of object to subject-and the capacity for this relation is part of the nature of things. And a relation which thus exists and is of the nature of things must be investigated. To refuse to investigate it would be a turning of science aside from its regular and legitimate path of advance in knowing the world; would be as genuinely a crime against the spirit of science as to refuse to investigate the laws of the tides, or of the planetary orbits, or of the development of organic types.

The relation, then, involved in that organic connexion of objects and intelligence which is science, must be investigated. And the question with which to begin the investigation is a very simple one: How is such a relation possible?

First of all, let us see what as mere matter of fact the relation amounts to. All science and all endeavour after science presuppose, as already has been pointed out, that the world is one, a single system of facts and relations. Furthermore, scientific statements, once they are truly and adequately formulated, are timelessly valid; can be handed on from generation to generation, and stand firm independently of time and the passage of time. This implies that the ultimate order of that cosmos which it is the business of science to know is an eternal or timeless order, a single system of fixed and unalterable relations. The upbuilding of science is a process wherein man "enters into" or "makes himself at home in" or, more accurately still, "reproduces in and as his own thought," that system of related facts which we call " the world," that system of eternal or timeless relations which we call "the order of the world." And in doing this, man acts the part of a permanent subject who (1) holds many diverse facts in orderly relation in the unity of a single conscious grasp, and (2) in so doing distinguishes himself from the various facts which he thus presents to himself-distinguishes himself from those facts in the 


\section{AND THE VISION OF GOD}

very activity of at once distinguishing them from one another and yet relating them all together in the unity of one scientific view. And must so distinguish himself from them; for to carry on such an activity at all-to hold, in and as one conscious experience, a vast variety of facts, keeping each one in its own distinctness, and yet relating them all together with a continually growing accuracy-the subject must, in a certain genuine sense, be above each and every one of the particular facts present to him; must, to use a metaphor which is not the truth but hints at the truth, be both the judge to whom, and the court in which, they are all present.

With this the question we began with is seen to have two sides. First, how is such a world possible? Secondly, how are we to account for the subject who knows that world-the self-conscious subject, able (partially, indeed, and discursively, but still with ever-growing com- $v$ pleteness) to reproduce that order of nature in his own thought?

First, then, how is such a world possible? The world that men of science investigate is, as every step of their work presupposes and implies, "one connected world." It is a single system. But what does that mean? It means two things: in the first place each of the facts or constituent parts of the world is related to every other-the total system of those relations being the "order of the world"; in the second place, each fact or part is maintained in the distinctness and integrity of its own existence, no one of them being in the order of nature fused or confounded with any other. But how can that be? In the first place, can it be explained by supposing that each of the ultimate constituent parts of the world-atom, monad, or whatever it is-institutes and maintains the total system of its relations with every other part? Here, indeed, there is no space to discuss such a theory at length. But it is not necessary. Let a man get clear to his mind all that such a theory means-each atom (or electron, or monad, or whatever the ultimate constituent part is supposed to be) from eternity an independent and omniscient consciousness which at each instant (1) knows the movements (or other activities) of all the other atoms in the universe and knows exactly what it should do to adjust itself to those movements, and (2) upon its own initiative and in its own power executes the adjustment-let a man get this 


\section{THE STUDY OF NATURE}

clear to his mind and he is not likely to continue to hold the theory. The solution given by such a theory has no relation to the problem which is being solved: it seeks to solve the problem of "the Many and the One" (or rather the Many in the One) by giving us a Many without a One at all. The theory which brings to this problem of the "one connected world" a solution that really does solve, and therefore must be accepted, lies in the other direction. We must hold, that is to say, that the existence of such a thing as a "connected world" implies a "principle of union" which does two things. It links all the facts together into the unity of one system. But at the same time and by the same activity it maintains each of them in its distinctness, not fusing or confounding them together. And to do this it must distinguish itself from each and all of those facts or events or elements which it thus both relates together and keeps distinct. To it they all are present: and since it is only through that presence to it that they have their places in the one system and so are what they are, it may be said on the one hand that their presence to it is their reality; and on the other hand that it is the source and home alike of them and of their relations to one another. ${ }^{1}$

But can science find anything of which it dare assert such an activity? Are we acquainted, in the whole circle of our experience, with anything which can exercise such an activity and so can be such a "principle of union"? The answer is that we are. Intelligence, $>$ self-consciousness, spirit,-or whatever other name you may wish to apply to that which the man of science himself essentially is-is precisely such a principle of union and exercises precisely such an activity. To hold many facts, many elements, together in the unity of one grasp, to relate them together and yet to keep each in its distinctness-this is precisely what it is the essential nature of selfconscious spirit to do. But in applying this principle to the solution of our problem we must remember that in us men self-consciousness or spirit exercises its power of synthesis only imperfectly. Our knowledge is fragmentary; our minds in their advance, though not

1 This problem of the "one connected world" is, in some form or other, the problem of all metaphysicians-even of David Hume. But it is interesting to note with what special clearness, and how early, it came forward in Greek thought, as the problem of the Many and the One. 


\section{AND THE VISION OF GOD}

in their essential function, discursive. Our world is, in one sense, a world given to us, and in apprehending it we pass from fact to fact; in mastering one part of it we have to leave other parts out of sight. But self-conscious spirit, as the principle of union of the world, cannot be fragmentary or discursive. It must be a single eternal spirit, to which the total system of things is present in one $r$ eternally complete grasp $;^{1}$ and present, not as given to it, but as constituted by it-constituted by it in an activity in which it acts altogether from itself.

So, then, the case thus far stands. We came face to face with a problem: How can such a thing as a connected world exist? Of the two roads along which a solution can be sought we found ourselves absolutely shut up to one-that which demands a "principle of union." And something which by its very nature can act as such a principle we found ourselves to be acquainted with. We have, then, a problem; we have a principle adequate to its solution; and we have but one such principle. To the straightforward scientific intellect, when it faces such a situation, there is but one course: to accept the principle and proceed with its farther application.

We must say, then, that the world, as a single system of facts, is the activity of a single eternal spirit, which by one and the same activity maintains the facts in their distinctness and links them together in one system; and which, to do this, must distinguish itself from each and all of the facts which it thus constitutes-being thus the source and home of the whole order of the world, or (to use the technical language of philosophy), in the sense already indicated the subject of the world.

But, as we saw, in order to explain how science is possible more is necessary than an account of how the objective world is possible. For science is the coming together of the soul and the world; is the organic union of subject and object. The world, we have been forced to say, is a system of facts present to an eternal spirit; it is the thought or activity of an eternal spirit. What then can man be, who in his science reproduces as his own thought that thinking of the eternal spirit? Here, again, there is no space to do justice to the

1 Totum simul, as mediæval men of thought were wont to say. 


\section{THE STUDY OF NATURE}

argument. All that is possible is to sum up in the briefest form its conclusion. The knowing subject cannot be accounted for by reference to any of those objects, of whose very existence as objects of scientific study its own synthetic activity is a necessary condition. Nor can it be "derived" from any of the elements of its own experience (such as feelings or sensations); for of the very existence of these as elements of a human experience, its synthetic activity is, once more, a necessary condition. It can be accounted for only upon the view that the eternal subject of the world has reproduced itself-or let us rather say, Himself ${ }^{1}$-in and as the human subject; has reproduced Himself in such a way that, under whatever limitations, ${ }^{2}$ the constitutive principles of our minds correspond to the constitutive

1 With regard to this verbal usage, it is perhaps worth while to say one thing: the important matter is not what pronoun a man chooses, but what he really means. When a writer (1) expresses the conclusion that the supreme principle of the world is an eternal spirit-a single self-conscious and self-determining spirit, the eternal subject of the world, perfect in intelligence and reason; (2) indicates that that eternal subject constitutes the whole order of nature, and that, in order to constitute any fact at all, it must distinguish itself from each and all of the facts which it constitutes; (3) makes clear that he derives that conception, which for him illuminates the world, from a consideration of the nature and essential activity of spirit as found in man ; (4) points out that that spirit is present among men, is active in the whole of history, winning human hearts to itself, and through them leading the race of men onward to an ultimate issue of divine love and divine righteousness:- at such a writer both the Manichæan and the Materialist, each from his own point of view, may have cause to feel enraged; but the theologian who is a Theist surely should recognise in him a friend, and more than a friend. It is a great pity that men who really are agreed in the principles that lie at the basis both of their thought and of their conduct, should stand apart because they do not understand one another's speech -some using a dogmatic dialect which loves ancient usages of Schools and Councils, others a tongue which has grown up in the atmosphere of science and seeks above all things (often with too violent a forgetfulness of the past) for accuracy. When we are so unhappy as to have to work by words rather than by action and affection, we ought, for the sake both of one another and of the truth, to do two things: we ought to set down our conceptions with clearness, articulating them definitely into their constituent elements so as to bring to light those subconscious meanings which we all hold and which shape our conclusions (and our lives) much more than we think ; and we ought to remember that most words have had histories-the word person, for instance, has taken on technical and sharply limited meanings in two great developments, that of Roman Law, and that of the theological doctrine of the Trinity-or to take another instance, the word substance expresses the category which has revealed itself in history as of all categories the one specially consecrated to Pantheism. Our Lord's was the better way, when, in speaking of the nature of God, He used the word Spirit, and in speaking of the relation of God to men, the word Father.

2 Limitations whose character may be suggested by pointing out, for instance, that we live in time; that an animal body is organic to the process of the development of our spirits; that the appointed conditions of that process of development are such that we enter only by hard labour, and by struggles and sorrows which go beyond all hardness of labour, into our inheritance of knowledge and of character. 


\section{AND THE VISION OF GOD}

principles of that thought or activity of His which is the world: For that reason, and only for that reason, are we men able to make ourselves at home in the nature which He constitutes, whether when, as children, we played amongst its flowers, or when we investigate it scientifically, or when, in times of happiness and still more in times of trouble and of loss, we find in it a companion and stay of our spirits:- just as a reader is able to study a book, and gradually to enter into its meaning, and gradually to have his mind strengthened and uplifted by it, because, and only because, the constitutive principles of his mind and being are in their essential character the same as those of the writer of the book.

Such, then, is the account which must be given, on the one hand of the world which is known, on the other hand of the soul which knows. But the two questions to which these are answers were the two sides of the one question: How is knowledge possible? And it is when we come back to that question in its unity, and put our two answers together as the answer to it, that we see the deepest strength of the whole argument and of the conclusion to which it leads. Man is able to know nature-to have science of nature-only because there , is an essential likeness between man and nature. The soul is able to go out into the world and make itself intellectually at home in the world-is able to take the world into itself and reproduce in and as its own thought that system of facts and laws which is naturebecause, and only because, nature is really what the soul is, a spiritual existence; because, and only because, nature is the thought of God and man is the child of God, able, no matter how imperfectly and gradually, to think his Father's thoughts after Him. ${ }^{1}$

That insight has never been better stated than in words which tradition ascribes to a man of science. Kepler, seeing that the power which carried on the stellar movements was acquainted with, and acted in the most exact accordance with, those mathematical principles which he himself had worked out in the council-chamber of his own pure reason, turned, it is said, from his telescope with the exclamation, "I think Thy thoughts after Thee, O God." Cases of

1 This is often expressed by saying that science is spirit finding itself in nature; and that spirit can find itself in nature, only because nature itself is spirit. 


\section{THE STUDY OF NATURE}

this sort, which nowadays occur ever more frequently-cases in which men of science come to conclusions mathematically (i.e., by the way of the pure reason), and then, turning to the telescope or to the laboratory, find that these conclusions are true of nature-are very marked instances of the community of the intelligence which is nature with the intelligence which is man. But the same view of the world and of the soul which is needed to explain the possibility of these, is needed to explain any knowledge of nature by man at all, even though it be but the little child's knowledge of the flowers among which it plays, or the primitive shepherd's rough acquaintance with the laws of wind and weather or the ways of plant and animal life.

What we have seen so far we may, then, sum up in this way: (1) The system or process of nature is a divine activity; is, if you will, part of the divine thought. (2) Our sciences of nature are the thinking of the thoughts of One who is invisible- a thinking of God's thoughts after Him. The growth of these sciences may be described, from our side, as our gradual entering into, or comprehending of, or making ourselves at home in, the content of the divine mind; and from the divine side, as God's gradual impartation of His thought to us. (3) And this process of thinking God's thoughts after Him, of reading the book which $\mathrm{He}$ has written-the book whose syllables are the growth of the flowers, and the ordered march of the stars, and the age-long development of animal organisms-is possible to us because, and only because, God has reproduced Himself in us; because, and only because, we are His children, made, intellectually, in His likeness, having our essential cognitive principles the same as the principles of the divine intelligence; because, and only because, to use an accurate but easily misunderstood expression, the human mind is potentially the divine mind.

So, then, even if we stopped. at this point of the metaphysician's regress upon the cor ditions of experience, we could affirm at least this much:- In every step and at every stage both of the nature which is known and of man's activity in knowing it, the presence and activity of the Eternal is implied. The whole process of the building up of the natural and physical sciences is a co-working of man with God, of the human mind with the divine mind. It is a participation of 
man in the Eternal Reason; is, for him who is willing to see the meaning of his own endeavours after science, part of the process whereby God becomes our dwelling-place and the home of our spirits. So that, even while the movement of history and the growth of mind are stripping away from cleric and priest and altar something of their awful splendour and long-asserted, compelling power, the sciences of nature have a sanctity which is immediate and cannot by any movement of history or change of institutions be shaken. For the courts of science, whether the men who labour in them recognise it or no, are sacred with the most immediate presence of the ultimate God. And their sanctity is but part of a wider sanctity. To him who is able to see the meaning and significance of science, every ray of light that the man of science flashes from his mirror, every minutest animal cell that he examines under his microscope, together with his own power of knowing these objects, is a witness that the world he dwells in is at once the activity and the temple of the Most High God.

Newman to some extent apprehended this. "Every breath of air," he somewhere says, "and ray of light and heat, every beautiful prospect, is, as it were, the skirts of their garments, the waving of the robes of those whose faces see God." But this is rather the word of the preacher catching a momentary glimpse of the glory of his God revealed in alien realms, than any assured and thoroughgoing vision of the real being of nature. For, in the first place, Newman the churchman (using that word for a moment as Newman himself would have used it) loyal to the very letter of the dogma of his church, could scarcely look otherwise than askance upon nature, and upon the sciences of nature, and upon the independent endeavour of philosophy to penetrate to the ultimate meaning both of nature and of man's knowledge of nature. And secondly-a worthier reasonhe felt so acutely the revelation of God in conscience and in man's inner heart, ${ }^{1}$ that he tended to overlook the revelation of God in nature, and to have no eyes for the fact that all knowledge of nature is in ultimate analysis knowledge of God, and is possible to man only through and as God's impartation of Himself to man.

1 See his deseription of his early religious feelings on p. 4 of the new edition of the Apologia: . . " making me rest in the thought of two and two only absolute and luminously self-evident beings, myself and my Creator. 


\section{THE STUDY OF NATURE}

But in Wordsworth we find both adequate vision-I had almost said, adequate comprehension-and adequate expression. The perception of what nature truly is; and the companion perception of what the true strength of our human life is :-these are the animating and informing soul of his poetry. ${ }^{1}$ That the contemplation of nature, the love of nature, the companionship with nature, is a companionship in which we lay aside our mortality, a companionship in which God imparts his mind to man and man's mind comes to dwell in its own proper home, its home in God:-this is the essential principle of Wordsworth's vision of nature. It is in this companionship with nature that we become living souls and see into the life of things, and the burthen of the mystery, the heavy and the weary weight of all this unintelligible world, is lightened, and we become aware of a deeper presence than before we had known, something far more deeply interfused than our first rapturous acquaintance with nature, our first delight in her glory of sound and colour, had taught us-
Something far more deeply interfused,
Whose dwelling is the light of setting suns,
And the round ocean and the living air,
And the blue sky, and in the mind of man;
A motion and a spirit, that impels
All thinking things, all objects of all thought,
And rolls through all things.

And it is Wordsworth's special crown of glory that with him this vision of the divinity of nature became also a vision of the sacredness of the ordinary life of man with its natural relationships, its natural duties, its natural charities. For him the heavenly light rested, as upon the lakes and silent hills, so also upon the elemental constituents of the life of man. The two together formed the one object of his work as a poet. For these as for those, he sought-not to bring a consecration of poetic light from without-but to penetrate to, and interpret, the heavenly nature which is their genuine being.

1 Perhaps one ought rather to say that these are the light of his poetry, the truth and insight which his poetry expresses; while its warmth, the restrained but immense power that is in it, comes from his own English heart-a heart most affectionate, and trained (like Plato's) by long discipline of tragic passion and deep peace. 


\section{AND THE VISION OF _GOD}

Upon this it is worth while to pause a moment longer. For it explains a fact most significant in itself and, to men of the church, full of instruction. It may appear remarkable in the extreme that men, for religion's sake, should take refuge from a prophet with a poet. And yet, when Newman is the prophet and Wordsworth the poet, that is what, to a certain extent and in a certain regard, we ordinary men living the ordinary life have to do. For (even leaving aside the fact that Newman, with all the intensity of his vision of the divine, came at last to look upon a single narrowly defined institution as the one thing in this world directly and distinctly of divine foundation), the very intensity of his vision of the unity of this life with the life to come dimmed his eyes to the unity of man with nature, and to the value of nature and of the natural man to God. But the unity of man with nature, and the unity of nature with God, Wordsworth saw with the clear vision of a daily and affectionate friendship.

Hence it is, too, that while we are still young Newman's lesson is the easier to learn and is the one that specially wins us; but when we grow older it is more and more to Wordsworth that we turn both for illumination and support. When we are young, and our hearts beat high, and the burden of the daily life has not fully come upon us, it is easy for us to despise the vanities of the world. It is easy to turn away from the noises of the earth, and from the littlenesses of the "practical life," and to enter upon that short and direct road to the heavenly glory which consists in repudiating the earth and' all its ways. But when we grow older, and life itself puts us in our places, and we are grappling day by day with the tasks of the ordinary life, and either in them or not at all must fulfil the vocation which we have from God; then we learn with a continually deepening gratitude to receive Wordsworth's lesson of the essential sacredness of the natural relationships, of the natural charities and affections, of the natural surroundings, of our daily life. It is not that Newman ever loses his high spiritual majesty in the eyes of any man who has once apprehended it; it is that Wordsworth comes nearer to us, and dwells with us in our daily cares, and illuminates our daily and natural life with divine and eternal light, showing us nature 


\section{THE S'TUDY OF NA'TURE}

and natural affection as a work of the grace of God and as a medium for the farther impartation of that grace to us.

But we must return to the argument itself. For the point reached a moment ago was one at which we cannot stop. The insight so far gained compels us to take a further step. And to that step we are driven whether we view the matter from the divine or from the human side.

First from the divine side. We have seen that the order of the world in accordance with which the world's history proceeds, is constituted by an eternal spirit who is the subject of the world; in a word, we have seen that the world is the thought or activity of God. But spirit, in any activity which has the form of time, proceeds teleologically. It "sees the end from the beginning," and in view of that end it arranges the beginning, arranges the essential conditions, the informing order and constitution of the whole process. It is involved, then, in the position already rached-nay, it is involved in anything that can be called Theism-that that whole activity of God in which Ile constitutes the order of the world and maintains the world, proceeds in view of an end or $\tau \dot{\lambda} \lambda o s$.

Or if we start from the human side we come to precisely the same point and almost by the same road. For man's life, so far at any rate as he enters into his moral and intellectual heritage, is a process of development; nature itself, which is at once the beginning, the home, and the stubborn material, of our life, being a medium which God uses in what may be deseribed indifferently as the communication of His mind to us, or as the development of our own minds. And so there arises the question: In a world-order which is rational, which is constituted by an eternal and self-conscious Reason, what can be the significance of such a possibility of human development? what can be the meaning of the fact that the form into which our life is cast is the form of development? Here also the position already reached leaves us but one possible answer. The eternal subject of the world, who does not act wantonly or blindly or irrationally, who does not make experiments, and to whom it is impossible to institute a beginning that forgets its end, has constituted the world, with its 


\section{AND THE VISION OF GOD}

possibility of human development, in view of a $\tau \dot{c} \lambda$ os which would be a true and genuine fulfilment of the beings and the eapacities that are the subjects of the development.

From both sides, then, we are brought to the conception of an end or $\tau \dot{\varepsilon} \lambda o s$ in view of which God proceeds in that activity by which the order of the world is constituted and the process of the world's history made possible. And the next step of the argument whose course and whose conclusions are being noted here, is an attempt to understand more particularly what that $\tau \varepsilon^{\prime} \lambda o s$ can be. Since the order of the world in which we now live is constituted in view of that $\tau \dot{k} \lambda \circ s$, certain conclusions concerning the latter are possible from a consideration of the former. Two of these may in the briefest possible form be indicated here. In the first place, that "far-off divine event" consists in a perfect society, a fully realised "kingdom of God," in which the capabilities of men, moral, intelleetual, artistic, developed only in part-often scarcely at all, and sometimes worse than not at all-in this world, reach their true and full development; and in which one person does not enter into his good at the expense of another; but on the contrary the good of all is the good which each one seeks, and therefore the attainment of his good by any individual means to that extent the attaimment of the good by all. In the second place, the perfection of personal character which is implied in the perfection of that society, is not only present to the divine mind as an idea; it exists, fully and eternally realised, in the divine character. In moral character, God Himself is, in eternal completeness, that toward which it is the rocation of the sons of God to grow; such is the End which is at once the promise of our life, and the measure of its genuine value, and the standard which sets in a light more awful than that of any day of wrath its present distance from its goal. So that science, in the last saying which it makes possible, places us among those multitudes of men who, with a sorrow upon which a great hope is dawning, listen to that other saying which is at once the judgment and the inspiration of their lives: "Ye shall be perfect, eren as your Father which is in heaven is perfect."

This then is, from the divine side, the $\tau \dot{\varepsilon} \lambda \circ s$ of the world; from the human side, it is man's eternal vocation. And the way of the ful- 


\section{THE STUDY OF NATURE}

filment of that vocation is the way of the cross; the way, as the greatest of modern metaphysicians so steadily insisted, of "dying in order to live"; the way of that self-surrender in which men yield themselves up to be the organs of the eternal purpose, and become, if one may thus express it, subordinate centres of the activity of the divine will, realising their own true freedom and coming genuinely "to have life in themselves" precisely in the measure that they apprehend the divine purpose, and obey the vocation which the very existence of that purpose constitutes for man.

With this latter insight-the insight that men come truly to be themselves, that they realise their true freedom and come genuinely to have life in themselves, only as they implicitly or explicitly apprehend the divine purpose and obey the vocation which the existence of such a purpose constitutes-the broad and general argument whose course we have in this section been following, comes full circle. From a problem of human life it began, and now it returns upon human life. On the field of human history-which in the last analysis means on the field of man's daily life-the eternal subject of the world is operating toward the realisation of His purpose; $;^{1}$ but not by iron assertion and enforcement of sovereignty; nor by mechanical action of the divine will or the divine grace upon man, such as in the common conception of things a physical force exercises upon a physical object. Rather the divine mind operates in human history toward the realisation of its purpose, by imparting to the human mind ideas and strivings which, however imperfect, are in a certain genuine sense "representatives to man" of the eternal ideal, and which, becoming operative powers in men's lives, lead human history on toward its goal. The historical process of the realisation of the divine idea is worked out, that is to say, neither by mechanical action nor by "mere sovereignty" on God's part, but in and through that which when viewed from man's side, is “man's devotion to the highest ideal that he knows," and which when viewed from God's side may be described as "God reconciling the world to Himself." In other

1 I am stating this from the point of view of philosophy and in the language of philosophy; and am so stating it because it is a conclusion of philosophy. But it may not be amiss to refer to such passages of Scripture as John v. 17.

$2 \mathrm{Cf}$. (under the qualification mentioned in the last note) Col. i. $20 ; 2 \mathrm{Cor}$. v. 18, 19. 


\section{AND THE VISION OF GOD}

words, the divine idea realises itself in history by an impartation of itself in which it wins men as free spirits to its service. By impulses planted in man's nature; by the appeal that suffering makes, and by all the efforts undertaken to alleviate it; by natural affection and all "the charities of father, son, and brother"; by the institutions, the needs, the opportunities, of society and social life; by prophetic energies aroused in solitary and burning hearts; by the ideals that under the pressure of some great need arise in men's minds, and move upon the face of a people's life, and win to their service its successive generations; in a word, in all that can be described as the natural development of morality and the natural growth of society; and in that in which divine revelation culminates-the character and action of Jesus, wherein the ideal for human life, and the constitutive principle, the eternal and ultimate law, of the whole order of the universe, ${ }^{1}$ stand revealed in absolute simplicity for all men's apprehension:-in all this the divine idea has been at work, and is at work, winning to itself all men that can be won, and through them leading onward the course of history and introducing into time the principles and the powers of eternity. ${ }^{2}$

\section{Cf. Col. i. 16, 17 (R.V.).}

2 I may perhaps be allowed a single historical reference. The great deterministic theologies (one hesitates to use party names like "Calvinistic" or "Augustinian") tended to make the divine purpose execute itself in almost the same way as the force which drives a machine fulfils itself through the various parts of the machine, none of which have "life in themselves" or any will of their own or any energy different from the energy of the one total machine of which they are parts. Against these deterministic theologies, which were really great one-sided philosophies, Arminianism was a protest, not so much of the philosophic intellect of man as of his outraged moral nature. And, as such a protest, it never worked out adequately the great truth which it had felt keenly rather than apprehended rationally. Indeed, it has been almost ostentatiously non-philosophical -seeking for practice without seeking for the reason of practice, and being historically less able to secure that very practice than its grim but convinced opponent. But the philosophy of the matter is clear. And it is one in which Calvinist and Arminian may very well unite. God is certainly supreme in His world; the divine plan certainly supreme in history. In its resolute and unflinching affirmation of that, Augustinian and Calvinistic theology had its hands upon a great truth; and in that fact lies the explanation of its immense practical power and efficiency. But, understood truly, that divine plan prevails, not as the sovereignty of an iron machine over its parts, but by "reconciling men to itself "; by winning to itself the hearts and wills of men so that they devote themselves to it to be its organs, and it has in them the spontaneous and yet subordinate centres of its work of realising itself.

But the men whose thoughts have lived with the past struggles of the human mind to understand the ways of God, even while under the leadership of a modern metaphysician 


\section{THE STUDY OF NATURE}

VI.

Such, then, is the point of view of that "greater whole of knowledge" which the natural and physical sciences by their very existence imply and call for. What is gained from that point of view is an insight, not into the complete detail of the system of the world, but into its essential and ultimate nature: in that sense it is a "knowledge of the world as a whole." And such a knowledge of the world as a whole is an interpretation of the meaning of life; for it is an account of the true character of that order of the world by which the conditions of our life are set. Whether this knowledge be called theology (as finding the truth of the world in God), or philosophy of nature, or philosophy of mind, matters little. For man is the son of God; and nature is that thought of God which is God's medium in communicating His mind to man, and thus developing in man man's own mind. So that to know nature, God and man must be known; and to know man, God and nature must be known. Any one of the threetheology; philosophy of mind; philosophy of nature-in order to be itself must be the other two; and to the extent that it is not, it

they point out that those antithetic views can be unified in a more comprehensive truth, know that the schools of theology themselves have. something better to show than onesided systems. Among those who have inquired concerning the relation of the world's history-the relation of the wills, the characters, the fates, of individuals and societiesto the divine nature, there is a greater than either Augustine or the Remonstrant against Augustine. If we are to be disciples in the schools of theology at all, the minds that are deepest and the hearts that most love God and live most in that love, will go back, it seems to me, past both these men of the West to that great and undying light which was the soul of Origen. If the word theology be taken in its strict sense as the human scientific wisdom which seeks to know God and to interpret the facts of the world in the light of that knowledge, Origen is the greatest of theologians. Greatest because he saw two things: that the conception of the divine nature is the supreme principle in theology ; and that the divine nature is love. He was not subject to that habit to which the Western mind continually (and very naturally) gave way; the habit of confining God's love, and all the communicative and disciplinary energies of that love, within the barriers of artificial legal requirement. To apprehend the meaning for theology of the love of God, one must one's self live in that love; and live in it with width of heart and spaciousness of mind. And to say that is precisely to describe Origen. In contrast with the spirit of Origen, the tragedy of Western theology lies in the fact that it has been too much the

work of the political and legal (indeed of the positively lawyer-like) mind, which in theology tends to view the rectifying of the relation of the sinful human race to God as a matter of mere transactions; transactions carried through by steps which are not ethical realities but rather are forensic conventions, external, artificial, unreal. Not that the West has been without hearts that have lived in the love of God. That which is deepest and most vital in the life of the West has been brought into being precisely by such 


\section{AND THE VISION OF GOD}

ceases to have the form of science and becomes the voice of authority. For the world is one; the ultimate order of the world is one; the knowledge of that ultimate order is one; and that one knowledge is at once theology and philosophy of mind and philosophy of nature. With the emphasis at one point, it is theology (in the sense noted a moment ago); with the emphasis at another point, it is philosophy of mind (which, in the only useful or respectable sense of the term, means philosophy of history and of society, with all that history and society include of moral and intellectual endeavour); with the emphasis at still another point, it is philosophy of nature.

And this knowledge, by whatever name it is called, is made possible to us by the fact that the "masters of them that know," in their long endeavour to understand nature, have steadily refused to stop half-way in the knowledge of nature; have refused to be contented with a study of the detailed facts of nature as mere facts; have stubbornly endeavoured to penetrate to the true character of nature as an order or system; and have found that the scientific gateway to this $r$ knowledge is the gateway of epistemology. For to the insight into the ultimate character of nature they made their way by considering the fact that nature is knowable to man; by dealing (to put the same

hearts. But they have been mystics, or saints, or laborious parish priests, or sisters of mercy, or, better still, laymen and laywomen living in the daily round and the common task as "friends of God" and therefore as friends of man-seldom theologians as theologians.

As one contemplates this history one cannot but wish that its sundered elements had somehow been united: the Western church, the Eastern theology; the Teutonic races, the Greek mind. But with whatever regret one looks upon the past, one must still remember that in its course is a hidden wisdom greater than our own. And though Origen's intellect was one of the most spacious that ever has existed upon the earth; though he loved much, and his heart was pure, and his theology also was therefore purenot tainted by human hatreds nor sophisticated by the use of legal conventions; yet the history decided that the future was to be not with him but with the great African who was passionate in sin, passionate in piety, passionate in devotion to the church, passionate in maintaining the many diverse positions to which his subtle intellect was led, and who mastered the mind of the Western generations to whom it was not given to respond to the unflawed saintliness which was the character of Origen nor to the untroubled and consistent light which was his mind.

But if the theologians of the past are to be of real service to us-and they can bewe must walk with them as their companions, not as their slaves. Hence it is not the need of the day that Origen should be set on Augustine's disputed throne. In theology there has already been too much of human masters and of their schools. The world of to-day ought to be occupying itself-and is coming more and more to occupy itselfwith the New Testament, and with that Son of man and of God, of whom, and of whose work upon human hearts, it is the value of the New Testament to be a record. 


\section{THE STUDY OF NATURE}

thing in other words) with the question, raised naively by Socrates, almost solved by Plato, reinstated for modern thinking by Kant, "How is knowledge possible?"

But when this point of view is reached, and this insight into the essential character of the world's order gained, the endeavour of reason to know the world is still not at its end. For what we have done is this: we have found man partly possessing, partly striving to possess, science of the detailed facts and laws of the world; and by inquiring how such science is possible we have gained an insight into the true character of the world and of its order. But that at once puts upon the scientific reason the obligation to turn back to the details of the world and to endeavour to give them, in the light and under the guidance of the insight just referred to, their higher and further interpretation. In other words, if you have seen that there is a divine plan of the world, logically you cannot stop. You have to go on to ask what that plan is: which involves nothing less than to ask what the place is, in that plan, of each of the particular parts of the total system; of each law of nature; of each determining condition of man's life; of each great era and decisive event in history; nay, even of each decisive feature and event in each man's individual life.

To put it epigrammatically, when philosophy reaches its goal its work is still not finished. The movement so far described, the movement from the multiplicity of the facts of the world to the eternal nature and eternal constitution of the world, might be called a movement from the circumference to the centre. But when the centre is gained, philosophy, whether as pure science or as a practical temper, cannot cease from its labour. From the centre it must return to the circumference, but bearing with it the light gained at the centre, and seeking by the aid of that light to comprehend more truly the details of the circumference. It must attempt, that is to say, to give to the particular facts of the world, the particular facts of nature and of history, their "divine interpretation"; must attempt to view them not only as facts to be described and classified, but also as elements or factors in a divine and rational plan. To use an ancient terminology, the first movement of philosophy is 


\section{AND THE VISION OF GOD}

along the upward way-the ofo's $\ddot{\alpha} v \omega$-but as soon as this movement has gained a vision of its goal, philosophy must turn to the downward way-the ososs $x \alpha \tau^{\prime} \omega$ - and return to the world, but bringing with it a new light for the understanding of the world. ${ }^{1}$

And this demand is intensified from another side. Do not human history and human society themselves contradict this account of the essential constitution of the world and this view of man's his- $r$ tory as a process in which an eternal purpose, divine and divinely rational, is being realised? When human society and human history are what they are, so wasteful of life, so filled with oppression of the weak by the strong, so tainted with mean and hideous vices, so confused and doubtful in the whole struggle of good with evil, how can they be interpreted as a process in which a divine purpose is being realised and a city of God built up :- a city of God, in which each member becomes all that he has it in him, in virtue of his divine origin, to be; and in which the achieving of the good by one contributes to (or rather, in its measure is) the achieving of it by all?

It is obvious that within the limits of an essay nothing more can be done than to indicate in the most summary fashion the general situation in which the intellect finds itself when it confronts this immense-nay, this infinite-field. ${ }^{2}$ Such an indication may be given by considering three points.

(A) To begin with the simplest matter, it may be noted that the main divisions of the field are fairly well marked out. On the one side stands philosophy of nature; not simply in the sense of an

I Such a demand for the return of philosophy or theology from God to the world, is binding upon that Idealistic type of philosophy whose central argument was indicated in the preceding section. And it is thus binding because that philosophy, setting out to understand the world, finds in God and in a divine plan at once the explanation of the world and the truth of the world. But the other type of philosophy with which we are concerned in this book-the philosophy (or theology, or religion,-for it is all three) of the via negativa -is, it will be understood, not subject in the same sense to this demand. For the essence of its method is, that it proceeds from the world to God, not by the synthetic movement of Idealism, but by denying the world altogether. Hence for it there can be no return from God to the world in the sense indicated above, but only the ineffable mystic rest in God. (Cf. supra, pp. 9, 10, and infra, pp. 116-150; 215 seq. ; 274 seq.)

2 But it should be understood at the outset that both the intellectual obligation to this task, and the pressure of the cruel problems which intensify it, fall, not merely upon some special type of philosophy, but upon everything that can be called Theism. 


\section{THE STUDY OF NATURE}

inquiry into the ultimate and essential character of the physical order ;1 but in the extended sense of an attempt to give to the details of that order their "divine interpretation"-their interpretation as sparts or elements in the total divine plan. On the other side stands philosophy of history. And here also the inquiry is not in the simple, but in the extended, sense. That is to say, the question at issue is not simply the question how history is possible; is not simply the question how that process is possible in which man, an intelligent and active spirit, lives in organic union with the material order and its laws, and yet devotes himself through his generations to the realising of spiritual and social ideals, and so makes history. ${ }^{2}$ It is rather the endeavour to see the stages and events of man's past history in their true meaning and their true light as steps in the divine plan of the world.

Each of the two may be said to begin with broad and general problems and to advance from these to particular problems. The general problems are closely allied to the elementary and primary argument outlined in the preceding section; and can be pursued by the human intellect with some degree of scientific success and profit. But the particular problems require for their solution a minute knowledge of the details of the divine plan, not attainable in any such experience as that of man upon the earth. In the philosophy of nature, for instance, the first and easiest of the more general problems arises from that character of the physical order which more than any other has impressed the modern mind: the unbroken orderliness which prevails in it, the unchangeableness and inviolability of its laws. This problem indeed takes us only a step beyond the general Idealistic argument already outlined; the conclusions reached in that argument suggest at once both the rational necessity of this "continuity" of the material order, and the possible limitations of it. And that from whichever side one views the spatial world: whether $(\alpha)$ as an expression of the divine nature, or $(\beta)$ as one of the media by which God communicates to man, and develops in man, man's own

1 For that inquiry would be simply a special application of the general and elementary argument outlined above in $\S \mathrm{V}$.

2 For that, once more, would involve simply the argument of $\S \mathrm{V}$. 


\section{AND THE VISION OF GOD}

mind. From the former point of view, the spatial order is regarded with reference to its source; and appears as necessarily sharing in the absolute orderliness and rationality of that source. From the latter point of view it is regarded with reference to its end. That end is the development of reason in man; and the medium by which reason is communicated must itself have rationality and the orderliness of rationality. The source is reason; the end is the develop- $v$ ment of reason; any medium employed by such a source toward such an end can scarcely be other than a systematic embodiment of reason. It is perfectly true that we men in our best endeavours struggle toward ends imperfectly conceived; perfectly true that the best means we can fashion for ourselves do not fully express even those imperfect conceptions; for we have to work upon materials of which we are not as yet fully (or even approximately) masters. But God is under neither limitation. The divine ends and the divine media and instruments, when known as they truly are, are all alike expressions of the divine nature. There is a limitation indeed. But it is not in God. It is in the minds of us men who are seeking to apprehend God.

In the philosophy of nature, then, general problems of this sort are not hopeless. But beyond them lies that which is almost hopeless: the endless range of particular problems; the task of comprehending the place and meaning, in the divine plan, of each particular law of nature and each particular stage and event of natural being. In this (for a reason presently to be stated), little is possible to us except conjecture. Such conjectures have indeed been made-from Aristotle's day to Schelling's; and often they have been both brilliant and happy. But they are always to be ranked as probability or as prophecy, and not as assured insight gained in the court of the philosophic reason by methods appropriate to that court.

And so in the philosophy of history. We have already seen ${ }^{1}$ how upon the field of history the divine mind operates upon and in and through the human mind; how to the human mind the divine mind imparts ideas and energies which are in some genuine sense representatives of the $\tau \varepsilon$ ' $\lambda$ os eternally present to God; how these become operative powers in human history and lead forward upon its way, 


\section{THE STUDY OF NATURE}

in religion and morality, in art and science, in society and the state, the spiritual development of mankind. The human intellect may work with some success (in Hegel has worked with some success) in tracing broadly this growing impartation of divine ideas through the main stages of history-Oriental, Greek, Roman, Mediæval, Renaissance and Reformation, eighteenth century, French Revolution and its era. But when we pass on to ask the exact "divine interpretation" of each particular event, it must be said (again for a reason to be stated presently) that we are going beyond the limits of the knowledge that is possible upon the earth. In such matters > we must be content for the present to live by faith, and by that illumination, poetic or prophetic, which to men of faith is not denied.

(B) But when this statement has been made, it is necessary as a matter of fairness to remind ourselves of the fact which was stated near the beginning of the present section: namely, that the endeavour itself is a legitimate endearour of the scientific reason. And that not merely in the sense that its problem can be stated without absurdity or self-contradiction; but in the sense that science must advance to it or remain radically incomplete. It lies directly upon the road along which science advances to the knowledge of the world; it not only forms an integral stage of the journey of science, it is the last and culminating stage. It is absolutely necessary to the completeness of the scientific knowledge of the world, absolutely necessary to that penetrating and thoroughly articulated knowledge of the world which it is part of the business of reason to acquire. And this last and culminating stage the scientific intellect must somewhere and sometime enter upon, unless it is to turn aside from its work of knowing the world as the world truly is. Nay, more than this must be said. Not the scientific intellect merely, but the total soul of man must sometime and somewhere enter upon (or at any rate progress for ever toward) an experience of this type, unless it is to turn away from its true goal_that union with reality, that union with God, in which faith becomes one with reason, and perfect activity is guided by perfect science.

And however remote such a consideration as that may appear, any philosophical writer whose speech is English ought resolutely to 


\section{AND THE VISION OF GOD}

insist upon it. For, at the point now in question, the sober and practical genius of the Anglo-Saxon race turns instinctively away from $\checkmark$ the further investigations of philosophy to the practical life. "Enough," the men of that race instinctively say, "of this too proud and too daring journeying of the reason into eternity. Once we are assured that modern science of nature does not take away from us the vision of God and of the 'far-off divine event' which is His purpose, but on the contrary confirms by its very existence that vision, we will turn again to the field to which we properly belong, to the practical life." This is the native and characteristic attitude toward philosophy of the genius of England, as it speaks through those of her sons who, for the solution of the intellectual difficulties that beset their moral and religious devotion, have found themselves compelled to go to the schools of philosophy. In one sense, indeed, the men who embody that genius have no philosophy; their traditional "school," the school of Locke and the Mills, stands, as a philosophy, at no great remove from being the sorriest thing under heaven. But in a greater sense, they have philosophy: they have the philosophic mind-the feeling for eternity, the sense for the reasonableness of things and for ordering life in accordance with that reasonableness. But this philosophic mind they have expressed in their own way: not in technical writings, nor in system-making; but in something better, in customs and institutions, in the concrete deed rather than in the abstract word. The majestic, yet reserved and moderate, elevation of the prayers of their great church; the ancient peace of their churchyards; the mingled dignity and simplicity of their family life; their mighty works of war and of peace, of commerce and of justice, done throughout all the world:- these are the works of their philosophy.

Such a national character is not a thing to be lamented. On the contrary, no man can live his life with integrity - the inchoate integrity possible upon the earth-without to a very great degree turning in that fashion from those "further investigations of philosophy." Yet such a national character makes it all the more necessary to insist upon the statement just made, that whether with reference to the scientific intellect merely, or to the whole nature of man, that 


\section{THE STUDY OF NATURE}

further stage of philosophy must somewhere and sometime be entered upon. For while the English are right in feeling that reason embodied in institutions is a greater thing than rational insight expressed in words, yet-if for the moment a Canadian may lay aside the restraint due from him and speak with the freedom of an Englishman at home-they run a double danger. In the first place, they are in continual danger of sinning against the spirit of science. And no power upon the earth-whether it be the genius and characteristic temper of a great people, or the proud spirit of ecclesiastical theology-can, without self-destruction, permanently repudiate the scientific spirit, or permanently oppose it, or permanently draw a line and say that thus far it shall come and no further. ${ }^{1}$ But in the second place, they are exposed to a still greater danger in the very field of their strength-the field of the practical life. Alike in their institutions and in their conduct, obstinate unreason and authority without intelligence too easily secure a footing; even when they are saved by the stubborn and half-instinctive devotion to righteousness which is their better angel, they are almost lost again for lack of devotion to wisdom. They labour hard in all quarters of the earth, performing the tasks laid upon them by that wisdom of the world which compels all the peoples to its service. But they labour blindly, in obedience rather to practical instincts and to their tenacious and masterful hearts, than to clear visions of the enlightened intelligence; and so they achieve great things, but in their greatest works make themselves often the fools of fate rather than its intelligent servants. They load upon their shoulders burdens from all the ends of the earth, and so accomplish the works of the world-spirit; but seldom is any vision of its purpose in their eyes, seldom the joy of its free service in their hearts. Doggedly and masterfully and blindly they struggle forward, animated by a spirit that is mixing itself with time and leading the centuries to a goal beyond the horizon; but even in thus playing their part and fulfilling their great vocation, they too often forget to be the sons of the hidden wisdom and remain only its strong slaves. They serve God, but "know it not"; they work His

1 The intellectual spirit that England needs, if her genius is to do justice to itself, is the intellectual spirit of Origen-or of her own forgotten son, Cudworth. 


\section{AND THE VISION OF GOD}

works, but look not upon His face. God fulfils Himself through their labours; but they themselves stand in constant danger of being exiles from God.

(C) But, this being once for all understood, we can return with clear consciences to the fact with which we are at this point specially concerned: namely, that the achievement of this ultimate goal of science is beyond our present powers, and beyond the horizon of our present life. If achieved by us at all, it must be through some such development of our capacities of reason as only a life to come can afford. Why this is, and what the loss or gain of it for us men is, may be seen by considering two points.

(1) The inquiry whose course was outlined in the preceding section was an inquiry into the ultimate nature, the true character, of the world. The conclusion was that the "material order" is really a spiritual system, or rather a factor in a spiritual system; that the world has its source in a divine and eternal reason; that there is a divine plan of the world. That conclusion was gained by the reason moving easily and securely through an elementary and absolutely simple argument. So that it is a conclusion both easy and safe ; no man who has once really comprehended the facts and arguments which lead to it can well cease from holding it in some form. But what we have now come face to face with is something very different. It is no longer the question, What is the true nature of the world ? It is rather the question, The truth of the world consisting in a divine plan, how are we to interpret each of the facts and events of our present world as elements in that plan? And that is a problem as difficult to the human intellect in its present condition as the other is easy. For let it be considered what it involves to state the exact place and meaning of any one element of a great system in the total plan of that system. It involves knowing the system in all the completeness of its detail. Only so can you exactly estimate the place of any one detail among all the others. And to the extent that your knowledge falls short of that kind of completeness, to that extent is your interpretation of the place and meaning of particular facts and events conjecture rather then science, faith rather than knowledge. It may be most brilliant and most happy conjecture; 


\section{THE STUDY OF NATURE}

the soul of man may apprehend the meaning of the soul of the world, even as some most fragmentary mirror in the remotest of the stellar spaces may receive and reflect the ray of the central sun; and so the conjecture may even rise to the level of such a faith, of such a prophetic interpretation of history, as a wise and good man might very rightly be willing to build his life upon. But for all that, to the extent to which the total plan in the particularity of its detail is not known, such interpretation of particular facts remains, as was said, probability rather than certainty, conjecture rather than science, faith rather than knowledge. And the extent to which, upon the earth, we are thus ignorant of the "total plan in the particularity of its detail," may be seen by considering a single fact: in the present life we move among beginnings; that which is to come after, only in the light of which can these beginnings be seen in their full significance, is hidden from our direct acquaintance.

But if this is so, what ought we to do with regard to philosophy of nature and philosophy of history in this more extended sense? Shall we throw them summarily overboard as endeavours merely and simply hopeless? To a question of this sort many will give, instantly and decidedly, an affirmative reply. But the men whose opinion in such a matter is best worth having will be held back from that summary procedure by one consideration. It is well for the human race to be kept mindful how great a thing its endeavour to know the world really is. Hence it is well that in each great intellectual era there should be men leading the forlorn hope of science into the field now in question; men great enough to compel respect for themselves and their work. Indeed, each of the three great intellectual eras has had such men. In particular, the three men whose names have already been mentioned together-Aristotle, Aquinas, Hegel-were such men. Each worked his way to ultimate principles, and then in the light of those principles proceeded to survey all the provinces of experience; and thus attempted to form all the science of his day into its " encyclopædia." And in connection with this there is one specially notable point. One of the three-Aquinas-was no solitary prophet of the comprehensive spirit of philosophy to a gainsaying age. $\mathrm{He}$ was a philosopher because of his age, and in his philosophy reflected the 


\section{AND THE VISION OF GOD}

temper of it. And the instructive thing is that the same comprehensive and organising spirit which led the thinking of the age to its culmination in an encyclopædic philosophy, led to something equally great on the practical side. It led to a partial success-partial of necessity, but probably greater than at any time since has been achieved-in dealing with that practical problem with which the whole life of humanity upon the earth is a wrestle; the problem, namely, of working out a social order in which every man has a place -a definite station with definite duties. Just because from this questing of the intellect into eternity we are about to turn back to the "every-day practical life," we ought all the more keenly to remember that the age in which men walked most confidently in those fields of philosophy from which we are here turning away, was an age in several most important respects greater than our own in this very matter of practical achievement.

(2) But, in the second place, if reason enters here upon a field where for most of us the footing is precarious and where only an elect few can do work which compels respect; if the work of philosophy changes at this point from the gaining of assured insight by an argument of absolute simplicity, to the laborious and uncertain work of interpreting details whose total scheme is not open to our vision:-so also at this point does man's need of rational insight change. If we may believe that there is a divine plan of the world, a plan rational and righteous, then it is no long step and no illogical step to the belief that if we organise our lives according to the best reason and the best righteousness open to our vision upon the earth, we shall be putting ourselves upon a pathway whose end will be the organisation of our lives according to the reason and the righteousness of the city "whose pattern is laid up in heaven." For, as already we have seen, the divine idea does not dwell apart from human history. The supreme principle of the divine mind is, and must be, the supreme law of that whole activity of God which is the world and the history of the world. But that divine idea, as also we have seen, does not act upon human history like a mechanical power upon material bodies. It acts by imparting itself to men, and shaping their spirits, and winning them to itself; thus it becomes at once the source and the 


\section{THE STUDY OF NATURE}

nourishment of all development of reason among men and of all human effort after righteousness. And so the reason and the

$\checkmark$ righteousness that men have so far been able to grow into must be looked upon as at once the result of, and the representative of, and the pathway toward, the reason and the righteousness that are perfect and eternal. And if this be true, we need not mourn greatly that the exact "divine interpretation" of the particular events of history and the particular facts of nature is hidden from us. The life of faith is justified. "Assure us," so we may say, "assure us that there is a divine plan of the world; that over all things rules, and through all history operates supremely, an eternal spirit who is living reason and living righteousness. Assure us that the ultimate power of the world is the perfection of that goodness after which we struggle so imperfectly; and that, therefore, the goodness which is to us a goal far-off and dimly understood is in truth both the ultimate reality of the world and the immanent law and 'hidden wisdom' of the world's process - $a$ 'wisdom' which may indeed be veiled under forms hard in the extreme for such a creature as man to read, and may indeed, in its clashes with the 'creative will's of man, seem cruel to its own servants, but none the less is working effectually and lovingly toward its goal. Assure us that the world is not in its real constitution a non-moral order which cares nothing for moral and rational ends and awaits with nature's stern patience the day when we men shall have perished and 'all things shall be once more as if we and all the labours of our morality and of our religion never had been'; but that, on the contrary, the eternal power which constitutes the conditions of our life is more interested than even we ourselves can be in the causes of human goodness; so that when a man sets himself about that work to which the present state of the human race incessantly calls everyone who is willing to hear-the work of saving men from the evils without them and within them, and of rousing in their hearts devotion to the causes of goodness-he is not dashing himself against an eternal and hopeless barrier, either in God or in nature, but rather is in line with the supreme power, the supreme law, the supreme purpose, of the world.-Assure us of these things and we will fight the

1 T. H. Green, Works, Vol. III., p. 278. 


\section{AND THE VISION OF GOD}

battle of life, if not in the strength of complete knowledge, at any". rate in the strength of hope and of faith. We will not lament that after a certain point the journeying of the reason into eternity becomes perilous or even impossible. At whatever point the check comes, we have at any rate learned enough to enable us to labour in faith, devoting ourselves to the causes of present-day reason and present-day righteousness, and trusting that in so doing we are making ourselves organs and instruments-nay, sons and fellow-workers-of the eternal righteousness. It matters little-at any rate it will not drive us to rebellion or to despair-that concerning the exact and eternal meaning of each detail we are for the present in the dark. We are willing enough to fight for a time in the dark, or on a borderground between light and dark, if only we can assuredly believe that the order of the world which sets all these conditions of our life is in ultimate analysis a reasonable order, and that the supreme power of the world is really favourable to us in our struggle after the goodness of ourselves and of our fellows. If only we can know that nature and history have a 'divine interpretation,' we will turn back to the labours and the battles of the practical life, willing enough that the full details of that interpretation should for a time be hidden from our eyes."

\section{VII.}

Such, then, in a brief outline of its elements, are the stages and conclusions of the greatest and safest argument which man has been able to work out concerning the nature of the world and the meaning of his life in it; an argument which had for the first of its worldprophets Plato, but owes its specifically modern formulation and conduct to an insight won partially and laboriously in old age by Immanuel Kant. The ultimate explanation of the world and of our life (so it finds) is an eternal spirit and an idea or purpose-the Good-which that spirit is realising in the process of the world. Reality - the universe-is a society of spirits; that eternal spirit and the lesser spirits in whom the eternal spirit reproduces himself. The existence of "material" objects means their being present to that 


\section{THE STUDY OF NATURE}

eternal self-consciousness and their having a place in the system of that divine thought. Our sciences of nature, with the mathematical and physical sciences which logically precede the "natural sciences," are, when viewed from below, an entry of ours into the content of the eternal mind; when viewed from above, an impartation of that mind to us, by which our own minds are developed; are, in one word, a divine impartation meeting a human effort. Morality, in the true form of its idea, is the devotion of us men to the service of that divine idea or purpose which is being realised in the history of the world, but which, as we have seen, makes its way toward its own realisation not by acting mechanically upon men, but by winning them as free spirits to its service. And religion, when it becomes truly itself, is the greater whole of which such morality is a part; is the effort after unity, in affection, in character, in activity, with the eternal spirit who is the subject of the world. So that the history in time of the universe, when seen as it truly is, is a process in which an eternal spirit realises an eternal purpose by imparting himself :- reproducing himself in spirits that are finite, and free in so far as their finitude permits; and winning those spirits to himself; and communicating himself to them both intellectually and morally, not only through the visions of poets and prophets, but also through every effort of the man of science after knowledge and of the good man after goodness; and so making possible the attainment of that City of God which is the $\tau \varepsilon^{\prime} \lambda o s$ of all his action and therefore the supreme law and immanent principle of the whole process. ${ }^{1}$

These are conclusions of philosophy; and therefore, in stating them the language of philosophy has been used. But it, like all technical language, has a certain reticence; so that it may be advisable to re-state in one or two sentences of more familiar tone, the conclusion which has just been summed up. To say, then, that the universe is a society of spirits, an eternal spirit and the lesser spirits in whom he has under limitations reproduced himself, is to say that the

1 This might be summed up technically by saying that one and the same thing is the supreme principle alike of Being, and of Knowledge, and of Morality and Religion. It is his clear insight into this and his steady insistence upon it, that make Plato the greatest teacher in the schools of philosophy ; and the one most salutary to the divided and distracted modern mind. (Cf. Philosophical Lectures and Remains of Richard Lewis Nettleship, lst ed., Vol. II., p. 218 seq.) 


\section{AND THE VISION OF GOD}

universe is a family, and that the relation between its members and the eternal spirit who is at once their source and their home is the relation of sonship and fatherhood. And that Father is-not merely has, but is-all rational and moral perfection. That is to say, reason, righteousness, and love, are at the heart of things; are the immanent law both of the constitution of the world and of the process of the world. And the reason, the righteousniess, and the love, which are thus at the heart of the world, are one thing and not three things; for each in order to be itself has to be the other two. Reason without love and righteousness would be merely a hard logic. Righteousness devoid of reason and love would be but an arbitrary and iron-clad law, such as would intensify all evil and thus defeat its own aim? And love without righteousness and reason would be no love at all, but something quite contrary to love-a weak and foolish indulgence working continual injury to its own object. In God reason, righteousness, and love, are one thing $;^{1}$ and in their undivided unity they are at once the

1 When one has apprehended this, it is at first with anger, but presently-when the long upward struggle of humanity through many different levels of thinking toward the light, has made its appeal to one's heart-with a feeling very different from anger, that one remembers the way in which Western theology, after the Reformation as well as before, frequently dealt with the divine attributes. That theology was developed in a legal and political atmosphere. Naturally enough it took for granted the legal view of the relation of God to the world; it used many specific legal conceptions, taken from Roman or Teutonic law ; what is still more, in thinking about God it retained the babits of the lawyer's mind-its acuteness, its argumentativeness, its delight in convenient but unreal distinctions, its tendency to rely upon serviceable arbitrary conventions instead of seeking pure truth for its own sake. Hence it was easy for this theology to rend apart the unity of the divine nature; easy for it almost to view the divine nature as a battle-ground of conflicting attributes-separating sharply the righteousness from the love of God, then virtually hypostatising these abstractions, so as to set them over against each other and thus make an opening for a forensic theory of atonement. But theology, so far as it imprisons itself in this framework of abstractions, does not know God; though the men who made the theology may have loved Him. To come at the matter from another angle -one very relevant to the mind of the church at the present hour-such theology, though it beld the Bible in great reverence, did not know the Bible. It was, in the correct though not in the sectarian use of the term, un-Evangelical; it did not know, and was not based upon, the mind of Jesus as recorded in the Gospels. For in the Gospels what Jesus continually insists upon, throughout His work of revealing and establishing the Kingdom of God, whose King is a Father, is His own unity with the Father. In His whole mission to the world, He is one with the Father ; that mission and that work, therefore, express the mind and attitude of the Father; they are not a forensic expedient for changing that mind and attitude. Jesus, to use St. John's great expression, is the Word, in whom the character of God and His.mind toward man are spoken forth : and that puts out of court for ever the idea that the mission of Jesus to the world either represented or made possible a change in the mind of the Father toward men. Hence it is, that as Biblical Theology- 


\section{THE STUDY OF NATURE}

nature of God and the law of every divine act; and therefore the immanent principle of that order of the universe which the divine activity constitutes.

These conclusions and the argument which leads to them have in the preceding sections been stated as matters that belong simply to the courts of the reflective reason. As such, they represent what any scientific inquiry represents-the intellect of man at its legitimate work of trying to understand the world it lives in. And that attempt needs no special defense or apology. To the endeavour to understand his world man is called by the laws and powers of his own nature; so that the effort itself is not merely a legitimate one, but is an integral and essential part of that activity by which man develops his own being, and comes truly to be man, and so fulfils his divine vocation.

But the greatest of all the masters who have worked in those courts of the reflective reason would not have left the matter upon that footing. To Plato, as his whole life and the whole body of his writings at every point make manifest, philosophy meant a temper and a character as well as an activity of the scientific intelligence. And it meant these three, not as standing apart, but as joined together in that indissoluble unity in which each shares the nature of the others and each contributes to the perfection of the others. It meant a life in which philosophy, as an activity and a vision of the intellect, has passed over into the "philosophic mind," and that mind has become the guide of conduct. Whether with Greeks or with moderns, the sounder any man is in character, the more unwilling he is that truth and life should stand apart. The integrity of his character compels him to seek for unity in his life; compels him, if he has apprehended a profound view of life, to seek to transmute that view of life into life itself. ${ }^{1}$

the science which studies the types of Biblical teaching from their own point of view and upon their own scale of internal proportion-makes its way in the thought of the church, and compels the church more and more to return to the mind of its Founder, those forensic structures which it was the delight of the political and legal mind of the West to build in the courts of theology cease to be either the home or the prison-house of the souls that seek to enter upon their true relationship to God.

1 In this no name can rank with Plato's. Yet we men of the West ought with piety to recall the name of one who helped to found philosophy among ourselves-the brave Roman to whom philosophy meant not only knowledge, but uprightness in action and 


\section{AND THE VISION OF GOD}

And not only is this essential to integrity of personal character. It is demanded also by the nature of truth simply as truth. Here, indeed, we are brought to a point about which misapprehensions cluster ; misapprehensions so passionate that it is advisable to set down both sides of the question.-(1) Philosophy does not create life. For philosophy is primarily science. It is an effort to understand. It no more professes to create the world whose ultimate nature it seeks to apprehend, or the life whose meaning it inquires after, than (for instance) chemistry professes to create those elements and those relations of elements which are the object of its investigations. The soul of man is by its original nature scientific, artistic, practical; and in its practice capable of morality and religion. Hence the life of man is a life scientific, a life artistic, a life practical, a life moral, a life religious. This is the given object, and what philosophy does is to attempt to understand it; is to attempt to apprehend the meaning of that life, and the nature of the world in which it is lived and by which its conditions are set. The man who urges that philosophy cannot create religion, and then finds in that the ground for an habitual dislike of philosophy or a passionate warfare against it, simply misapprehends the whole situation. And such a misapprehension, it ought to be understood, is a revelation of the man himself. But (2) philosophy can be of use in guiding life where life already exists. For truth, simply by being itself, has power over the soul. To make truth merely cold and dead; to deny that the visions of reason can afford any awakening or inspiration to the moral and religious nature; to regard light as nothing and heat as everything; to set science and life, knowledge and goodness, truth and religion, radically apart:- this is to shiver man's nature into blind and crippled

fortitude in affliction, and who handed on his lesson to be a consolation to many a saddened heart in the troubled West. Philosophy, so Boethius learned and taught, is the love and pursuit of that wisdom which is the quickening mind and primeval principle of things; is in some sort a fellowship with it, so that the intelligent mind is at once illuminated by it and drawn back into it. So that philosophy, in being the pursuit of wisdom, is a pursuit of divinity. For that wisdom which is the eternal principle of the world imposes the worthiness of its own divinity upon all the souls that occupy themselves with it, and brings them to the force and purity of their own true nature; and thus arises not only a truth of speculations and thoughts, but also a holy chastity of acts. (See the finely sympathetic account, and specially the analysis of the De Consolatione, in Maurice. The foregoing sentences are from Maurice's statement of the conception of philosophy found in the first dialogue In Porphyrium.) 


\section{THE STUDY OF NATURE}

fragments, instead of recognising that the true power and perfection of that nature consist in a unity in which each part contributes to all the others. The man who habitually does it, and imagines that he is serving religion thereby, may mean well. But it ought to be pointed out to him that, to the extent to which this tendency dominates him and is not counteracted by other and sounder things in his work, to that extent he is making himself really a valuable servant to only one kind of religion-that which, having no truth in it, wishes to have nothing to do with truth. ${ }^{1}$

We can see then, to return to a statement of a moment ago, how from both sides-from philosophy as intellectual truth, from the integrity of character which forbids men to let truth and life stand apart-there is a compulsion to the attempt "to transmute one's view of life into life itself." Indeed it is only for the men who recognise that compulsion, or rather it is only in such men, that philosophy does its true and full work. And to attempt to gain some hint or glimpse of how in such men philosophy turns, through the " philosophic mind," back into life, is the last thing that we have here to do.

It can, indeed, be only a glimpse. But it is worth while to try to gain even a glimpse. For what the philosophic mind brings to our life, is the habit of regarding and valuing the goods of life from the point of view of that eternal purpose which man's life is intended to realise. And never was the need of that habit so great, whether on the part of the leaders of society or on the part of the general body of its members, as now. For the resources of society, both intellectually and still more in the subjection of natural powers to man's use, are greater than ever before. But owing to the assertion, throughout $>$ the whole of society, of the individual in his private and selfish interests, those resources are most wastefully used. A few specially

1 Of course, in thinking of truth as a guide of life and an inspiration for life, the fact noted in the introduction must be kept in mind. There is a tendency in us all to overlook the radically important distinction between abstract and concrete truth. A man of science, for instance, who deals with some one aspect of reality in strict isolation from the others, easily forgets the abstractness of his own special science; easily is tempted to think that its principles give the final account of the world and of our life. Thus we get those "premature and hasty" world-views of which Materialism and the mechanical view of the world are examples. (Cf. supra, pp. 4, 5.) 


\section{AND THE VISION OF GOD}

skilful or fortunate men possess them-frequently to their own inner evil-in large measures; while to many they are only very scantily available, or not at all. And the solutions so far wrought out are tainted by the evil itself which they seek to cure; for they are only those partial and bitter solutions which separately organised classes $v$ are able to win and to maintain at the point of the sword.

In the first place, then, the men in whom philosophy has become the philosophic mind have learned the first and most fundamental of all practical lessons. They have learned what the true business of life is. Stated on its positive side, it is the winning of men's hearts to those causes of goodness (goodness as including "all science, all art, every virtue and all perfection") which are the causes of God, and in the service of which men at one and the same time fulfil their divine vocation and come to be truly themselves. It is only as taking its appropriate place in that endeavour that any resource of nature which man has mastered, or any power of his own mind or heart or hand, is rightly used.

But secondly, in what they have learned concerning the world, such men have not only an illumination with regard to what the business of life is. They have also in it certain great sources of strength and of steadiness as they turn to the actual performance of that business of life. To begin with, they have what for want of some better name one must call the strength of hope-the strength of a faith which reason justifies. For they have learned that however Manichæan the present appearance of our life may be, there is no Manichæism at the eternal heart of things. They have learned that there is no eternal moral dualism in the universe, such as can set to the endeavour of good men after goodness (not their own individual goodness merely, but the goodness of all their race) a hopeless limit or a final defeat. For what they have seen is this: that the legitimate and inevitable onward course of the scientific reason, the legitimate and inevitable onward course of that attempt to know the world, of which physical and natural science is one stage, ethical and social science another stage, brings us at last to the vision of a God who is over all and in all, and by union with whom men may enter upon courses of ministration to their fellows, which shall be checked by no eternal limit 


\section{THE STUDY OF NATURE}

nor defeated by any eternal barrier. For to Him goodness is of absolute value; it is the end for which He constituted and keeps in existence all His worlds. And as His end can be defeated by no other god greater than $\mathrm{He}$, still less can it be defeated by any change in Himself or in His attitude toward men. At no point whether in this world or in any world, can He either forget the end for which He made the world, or lay aside the character which makes Him love and welcome the effort of His creature after goodness. He cannot at any point lay aside the character in which reason and righteousness and love are one; cannot at any point turn away for ever from good men in their struggle for the world's goodness, and thenceforward return to them for ever the answer: Hitherto shall you come, but no further; and here shall all power of self-sacrifice, and all passionate striving of love, and all devotion to the extension of the Kingdom of God and of good, eternally be stayed. On the contrary, it is His very nature, as the source and home and end and ultimate power of the world, at once to make possible and to respond to for ever, that prayer which not only ascends from the depths of man's sin and from his extremities of conflict and of defeat, but is also the normal and habitual "human cry":

Cast me not away from thy presence;

And take not thy holy spirit from me.

So that these men go forward into life-into life as life is, with its anguish of burdened and fragmentary and broken labours, its still profounder anguish of evil triumphant and good causes beaten backknowing that even if the worst come to the worst the ultimate truth of the world still forbids any paralysis of despair. They have that same source of unfathomable strength which the Stoics and the men of Geneva had: they know that they are devoted to the cause which in all history is supreme and final, that they are in line with the ultimate law, the eternal and present purpose, of the world; so that even though they seem to the view of this world to be defeated and to perish, yet really the universe is with them and the stars in their courses are fighting for them. ${ }^{1}$ And in addition to this, they have

1 As Wordsworth knew; and the knowledge was part of his poetical being. The sonnet to Toussaint L'Ouverture brings it to very pointed expression; but it is always in Wordsworth's mind. 


\section{AND THE VISION OF GOD}

what the Stoics had only in part and the men of Geneva scarcely allowed themselves at all-a vision of the essential rationality of the supreme power. And with essential rationality, essential kindliness; for while eternal reason may seem to us men an austere thing, teaching by the discipline of changeless laws, and bringing without fail to every human soul the consequences of its own deeds, yet in the ultimate truth of things such reason is with love, and love with such reason, interchangeable; and the form of their co-operant action is righteousness.

And so these men, in so far as they are able to make their way of life respond to what they know about the world, bring to the battle of life a certain grave and unyielding courage, a certain patient steadiness. They have looked upon eternal ideas, which are greater realities than all the "hard facts" and all the "actualities" of to-day, and which are at last to subdue to themselves these facts, and all facts, and to make them obedient servants in a realm where the eternal ideal is at once the real and the soul of all reality. Men who have seen such things, and are able to rejoice in them, are not likely to be cowards. And eyes that gaze habitually into eternity are wont to be steady eyes and to impart to the soul behind them the steadiness of the eternal objects upon which habitually they are fixed. "God is patient," so a great saying runs, "because He is eternal." The things that drive us to the edge of despair-the good that we see so clearly, but cannot bring to pass; the warfare of the brute facts of the world against that in us and in our fellows which is gentlest and touched most with heavenly light; the strange failures and defeats that here shatter a good cause or yonder blast into deformity an individual life; the unspeakable meannesses and cruelties that are practised by the strong and the fortunate against the weak and the defenseless-meannesses and cruelties of which the world is full, and in presence of which a man's indignation scarcely can keep itself from falling to wild anger; $\iota$ above all, the lives that are born in evil, and pass to the life to come never having known anything but evil:- these things do not mean that God and the good have a power over against them able to defeat them. Nor do they mean that God is absent from the world, and that we must give up the ancient teaching that "God worketh until 


\section{THE STUDY OF NATURE}

now." They mean the patience of a vast design. In presence of them the man who is devoted to goodness has to remember that in all such things there is ultimately but one question; it is not a question of death or of time; it is a question of God. And with God there is no failure; it would be easier for the heavens and the earth to pass away and all things to come to nothingness, than for any single act, done in any age for righteousness' sake or for love's, to fail of its due result.

Such a "philosophic mind" is not the first power of life. Love and devotion are the first powers of life-and the last. And love and devotion can work in the dark; with blind eyes they have done their most heroic deeds. But soon or late their very nature leads them to this calmness and patience of minds that see present things in the light of the eternal. For soon or late their nature leads them to look upon God; and, looking upon Him, they learn to see things under the form of eternity. And then their "last enemy" is overcome; for from the point of view of eternity our enemies and our tyrants are seen to be our friends. But the best way to understand this is to state it in the terms of a more ancient conception. Our life is a wrestle with a power not ourselves; a stern and unfailing power that with no shadow of weakness goes straight onward in its way, over the hearts of men, over the plans of men, orer the prayers of men. Men of science are content nowadays to call it Law, but in their older language they called it Necessity; ancient poets called it Fate. To human life it is present in many forms: sometimes as an iron limitation; sometimes as a foundation to be built upon; sometimes as a taskmaster bringing to men labours that they would not have chosen and responsibilities such as appall the soul; always as a law to be obeyed and fulfilling itself with absolute exactness upon the disobedient. It can never be eraded; nor can any man overcome it save by submitting to it and taking it as the law of his own being. But such unity of the individual soul with the necessity that operates in the world and in the history of the race, is doubly difficult to attain. The rery capacities that make us human set us beyond that easy and perfect obedience to necessity which is within the power of the leaf or the tide or the star; and furthermore, howerer willing our hearts might be, its 


\section{AND THE VISION OF GOD}

operation in history proceeds with so vast a movement that as it works upon the individual life it manifests rather its crushing power than its law or its goal. And so we dash ourselves against it with that pain, that blind and hopeless agony, that mad indignation as against a fundamental injustice in things, which has made its cry heard in human literature from the beginning until now. ${ }^{1}$

But in so far as a man is able to see the world and our life "under the aspect, as it were, of eternity," he looks upon necessity at its source; and looking upon it there, sees it in its true nature. It is eternal and rational and righteous; for it is the earthward aspect of the divine reason, the form which the divine action takes on to eyes that are not yet able to read it clearly. Unfailingly and unfalteringly it "reaches from end to end, sweetly and strongly ordering all things." Only when viewed from below does it appear mechanical and without a soul. Its vast plan we cannot, indeed, grasp in detail. But we can know its nature; we can know that Fate is the wisest of all things, and that in that "history of the world" which is " the world's court of judgment" the decisions which ultimately are given need no reversal.

And the man who knows this, knows that necessity is the disciplinarian of the soul, and is therefore his friend. He knows that necessity is the source at once of the greatness, the difficulty, and the security, of the good man's life. It is the source of the difficulty of that life; for it brings the soul to desperate passes-it makes its journey long and stern and its conversion a lifelong process in which each upward step leads to the unveiling of greater issues and the opening of wider struggles. It is the source of the greatness of that life; for it is by his long struggle with necessity-the struggle in which victory is won only by apprehending the wisdom behind that inexorable face, and submitting to it, or rather growing up into it-that man comes to be man, that the greater powers of his nature are developed, the greater achievements of his spirit wrought out. For it is upon a system of necessity which no individual will can break down or throw into confusion, that all orderly labour, mental or physical, is based; of -such necessity literature, in its higher forms, strives to picture the 


\section{THE STUDY OF NATURE}

incidence upon life; science is a study of its ways in nature, philosophy an attempt to penetrate to its real character; the theology which does not deal with it may indeed be happy, but is happy because it is still a child. The necessity which lies beyond the control of the individual will and is "the hidden wisdom of the world" is, in fact, the form which the love that works throughout the whole process of the universe assumes in order to become the schoolmaster of the human soul. ${ }^{1}$ And as necessity is thus the source of the difficulty and the greatness of the good man's life, so is it also the source of its security. For it is the last law - and the first-of necessity, that ultimately the fate of every soul shall be an absolutely righteous and rational fate-righteous and rational as righteousness and reason are in God. In the end no soul that lives will have anything of which it can rightly complain; without possibility of error every man will come at last to his own place.

And in addition to the necessity which thus is present in nature and history, and shapes for the individual the unchangeable conditions of his life, there acts upon the good man a necessity of a different order. It is that moral necessity which arises out of the very character of human life. We are citizens in a temporal and earthly order. But our vocation has its home in eternity, and in its demands knows nothing of the limitations of time. So that to the good man-to every man who is not a coward, evading the demands of the world upon him-life itself is a continual call to the bearing of a burden impossible to be borne, to the performance of duties that are beyond man's power. What ought to be done, again and again we cannot do, or more often can do only in part; and we come down to the grave weary men who have struggled hard and at the last are but unprofitable servants. But the insight into the nature of that other necessity sets this also in the true light; like the other, it is in its very sternness and oppression the ally of the man whose soul is turned toward goodness. Here, as there, when we enter into the heart of what seemed a power inexorable and indifferent, what we find is the deep heart of a friend - a friend too wise to make any mistake, too kind to admit even the slightest particle of weakness or indulgence into that system of things

1 One cannot pass on without referring to the noblest of the modern expressions of this-that contained in Tennyson's In Memoriam. 


\section{AND THE VISION OF GOD}

which is the framework of our life. If man's vocation goes beyond his opportunities, if his "ought" stretches on infinitely beyond his powers, so that after a long struggle he finds himself still an unprofitable servant, there is even in this no cause for lament or for complaint of injustice. That life should be an endeavour to overtake a vocation which runs beyond human powers and human opportunities is better for us, is infinitely more worthy both of God and of man, than that we should remain untroubled children for ever, with only such duties laid upon us as our powers are adequate to perform. Only through a life so constituted and through such struggle can children of time and of the earth rise out of their childhood, and enter upon their inheritance and their true being as citizens of eternity; and better the breaking of the heart than failure from that citizenship.

So that, in the presence of evil and of necessity, the men who have passed from philosophy to the philosophic mind are like soldiers who, in the midst of some long struggle, have looked through the struggle and have seen behind it eternal powers and eternal destiny. And with that, so far as their character responds to their knowledge, their courage takes on a new character; to the old stubborn tenacity which out of mere manliness could not yield, there comes a lofty intellectual soul of vision and of hope.

But this new order of courage in the presence of evil and of necessity is only a single aspect of what the soul comes to be, as truth and life become one. Along with it goes another quality of the soul; a quality less stern and therefore apparently less high. But really it is both higher and more difficult. For it is one of those virtues of comprehension which always are harder of attainment than the virtues of conflict. It is what may be called the virtue of catholicity; the strength and steadiness which catholicity of mind gives to a man in presence of the contending parties, contending interests, contending solicitations, of the world. For let us remember once more what the philosophy here in question has to teach us, both about the business of our lives, and about the world we are living in. The constitutive principle of reality-so it teaches-and therefore the condition of all knowledge and the regulative principle for all conduct, is the good. And the good is one; it consists in a perfect society, a civitas Dei, the 


\section{THE STUDY OF NATURE}

7 character of whose individual members is that character which is already and eternally real in God. Furthermore, it is (as the ultimate principle of the divine activity) at once the animating purpose and the inner unity and the "hidden wisdom" of the world. The troubled process which is life and history is a field wherein it wins men to itself, and, by imparting itself to them and so making them truly men, works out its own realisation. So that there is in all life and in all history one supreme object for the devotion of all men. It is only as being a stage in the realisation of that divine idea, it is $>$ only as being a step toward the bringing into being of that civitas Dei, that any duty is a duty at all, or any labour worthy of being done, or any cause deserving of support, or any institution worthy of loyalty. At all times and in all places and for all men that divine idea is the one determination of the path of duty. It therefore is the one object of endeavour that is truly catholic; the causes that make for it are the only truly catholic causes; devotion to it and to those its causes is the one true catholicity; and the man to whom such devotion is the supreme and organising principle of life is the one true catholic.

This does not mean any aloofness from life. Nor does it mean that life is to be reduced to a flat monotony of devotion to an indivisible One. On the contrary, as many as are the capabilities of human nature, so many are the pathways of the divine idea toward its realisation. But it does mean that there is eternally in God an end or good, as wide as life, which is at once the constitutive principle of the world's order, and the true guide and goal of human action: and, as such, is the standard of judgment for all human causes and purposes and enthusiasms; for all subjection of the immortal spirit to the body; for all use of the resources of life in vain display; for all sectarian divisions; for all that political and social selfishness which puts individual interest before general welfare; for all those ideals and passions and ambitions which set men apart from one another, and break the unity of society in church and state, and lead to the oppression of man by man or class by class.

Something, then, such as this, is what philosophy means when it becomes the philosophic mind. But what has been said is only a hint. 
Other qualities of that mind might have been spoken of ; its willingness, for instance, to recognise the presence of God-in nature, in the movement of history, in those great lay activities and virtues which sometimes the religious despise. But in particular one thing-and that the most important of all-which might have been dwelt upon, has not been dwelt upon. We saw that the universe is really a great family - a society composed of an eternal spirit and the lesser spirits in whom the eternal spirit reproduces himself, for whom he sets a vocation, and to whom, in science and in art, in morality and in religion, he more and more imparts himself, reconciling them to himself, winning their hearts back to himself, and by that reconcilement and that impartation enabling them to become truly themselves. But such a view of the universe is a call to personal affection and personal devotion, and to all the energies and powers, to all the passion and all the achievement, of such devotion and such affection. And if that view of the universe be philosophy, the philosophic mind must in the true form of its idea be the same as the religious mind-the mind which in the activities and energies of a supreme affection seeks to become more and more at one with God and with that purpose of God which is the ultimate law alike of the world and of man's being. But of that no mention has been made, in the attempt to give the reader some glimpse of what philosophy is when it passes over into the philosophic mind, and transmutes itself into life and temper and character, and so does its full work. And for that silence there was a reason. It is only in some world to come, when the philosophic mind, and the moral mind, and the religious mind, have all risen to the true form of their idea, that we shall be able to see them as one and the same. For our present world the fact stands that such affection as is here in question is commonly roused in men in a way which does not begin in intellectual vision. Speaking broadly and allowing for a few striking exceptions, the work of philosophy in this respect has been, not so much to rouse in men the love of God, as to do a certain work for those who already, and by other of the divine agencies of reconciliation, have been led to make that love the supreme principle of the practical life:-namely, to clear their eyes, and to give an intellectual soul to the vision of their 


\section{THE STUDY OF NATURE}

faith, and to cast upon their world and upon their path through it a broad illumination of rational light.

We must say, then, that philosophy, in its greater and clearer forms, leads us to see that the love of God should be the supreme principle of life. But we must also say that philosophy in those greater and clearer forms is the possession of a few. What is needed for the whole wide race is something that in human form and human affection can lie close at man's heart, that can illuminate with personal example all the events and relations of his life, that can be received by the simplest and the weakest, in a way not possible to that which is primarily an endeavour of the intellect and a construction of the scientific reason.

And in this connexion there is in the history of philosophy a most remarkable fact. There came an age in which, for many high and pure souls, philosophy had no choice but to undertake the guidance of life; in fact the need was so profound that philosophy, for the sake of the practical life, had even to set about the task of purifying religion. ${ }^{1}$ In the greatest of her masters philosophy rose to meet the call. The intellectual and moral splendour with which the task was discharged, they most admire who know the story best. Indeed the man must be very narrow in sympathies, or very ungrateful, who can look with merely fault-finding eyes upon what philosophy was, and upon what philosophy did, as she tried to meet that awful need of the spirit which already in Plato's day was descending over Greece. But precisely in that day, precisely when philosophy, called to bear a burden too great for her, summoned all her powers and rose to her most starry splendour, with the genius of prophecy, the genius of art, the genius of science, labouring together in her courts and at her commandprecisely then it was that her spokesmen wrote in her records a double cry: the cry for a revelation beyond his own; and the high resolve of the natural soul to make the best of the stern situation, so long as that higher revelation was denied by heaven to men. "I will tell you my difficulty,"-so Plato makes Simmias to speak in the Phaedo ${ }^{2}$ - and Cebes will tell you his. I feel myself (and I daresay that you have

1 Cf. Republic, $377 \mathrm{E}$ seq.

285 C. (tr. Jowett).-Socrates, it will be remembered, is about to die. 


\section{AND THE VISION OF GOD}

the same feeling) how hard or rather impossible is the attainment of any certainty about questions such as these in the present life. And yet I should deem him a coward who did not prove what is said about them to the uttermost, or whose heart failed him before he had examined them on every side. For he should persevere until he has achieved one of two things: either he should discover, or be taught the truth about them; or, if this be impossible I would have him take the best and most irrefragable of human theories, and let this be the raft upon which he sails through life-not without risk, as I admit, if he cannot find some word of God which will more surely and safely carry him."

Plato did not know that for the desire of which he had been a prophet, there was to come a fulfilment more genuine than he had dreamed: not in a great argument, sounding onward in a voyage that few could follow; but in a life that had dwelled where Plato desired the philosophic soul to dwell-in the bosom of eternity - and came to man with a kindliness, with a simplicity and directness of humanity, with a "loveliness of perfect deeds," which every burdened man, and every little child,

And those wild eyes that watch the wave In roarings round the coral reef,

can apprehend. And Plato did not know that, soon after that life passed from among men, He who had lived it was to be apprehended "under the form as it were of eternity" by two great masters of life and of thought. The one declared that in Him the universe consists; that $\mathrm{He}$ is the supreme law of the whole history of man and of the whole system and process of the world. The other, using the same word that Plato had used, declared that $\mathrm{He}$ was the Word, the divine Word, which reveals the eternal to men and gives them such vision as man needs of that divine idea which is at once the law of the world's order, and the condition of all knowledge, and the good for all human endeavour. $\mathrm{He}$ is the manifestation of the ultimate God; and in Him is summed up the law of the world; for these two things are one, each involving the other. But these great offices $\mathrm{He}$ discharged upon the earth, not in the form of some blinding 
majesty which could have taught us only our own nothingness, but as a man, who in purity of heart and in simplicity lived for others; lived for us all, and from the Galilæan fields and from His cross speaks still to the hearts of those for whom He lived. And as His appeal comes to us, some of us look upon Him early, and love Him, and walk in His way. But others of us go out proudly and in strength to our work, and suddenly, we know not how, are in the grasp of powers greater than ourselves, and come to the end of the day broken men; and beneath the gathering shadow, with the house of life in ruins about us, turn to Him, and receive from Him hope that rises above the scene of our defeat, and the gift of peace, and power at last to overcome the world. 
THE METAPHYSIC OF SPINOZA 



\section{THE METAPHYSIC OF SPINOZA.}

I.

IN our effort to apprehend that reality of things which is also the truth of our life, new insights come but slowly to full possession of themselves. A new method, a new category, a new point of view, seldom comes to its right in a single man or a single generation. Through many men a school labours toward a goal not clearly apprehended at the beginning; a goal from which the founders, could they have seen it, might have turned in dismay. But the method more and more does justice to itself; the tendency enters more and more fully into its own meaning; and at last the man arises in whom the school finds at once its culmination and its end. The system of thought which such a man leaves behind him has more than the purely scientific interest. It marks a finished stage in one great side of that human pilgrimage through time which is history; it takes on the dignity, the grave and moving interest, of a concluded chapter of human fate. A given tendency in man's long endeavour to know himself for the thing he is and to shape his life according to that knowledge, has been carried to its utmost limit; a given method employed to its utmost power. All that this tendency, all that this method, can do, it has done. It began as best it could. It worked its way forward through its stages, clarifying itself and learning to be true to itself as it advanced. And now it has assumed its final shape; has made manifest at last the meaning which was in it. Henceforward, in that "history of the world" which is "the world's court of judgment," it abides, an achieved fact, standing face to face with its opponents and awaiting verdict.

There have been three chief instances of this in modern thought. One stands strangely in the midst of its school. David Hume carried to their logical conclusion the point of view and the method of 


\section{THE METAPHYSIC OF SPINOZA}

English empiricism; and by doing so showed their hopeless inadequacy to the task of understanding how our experience can be what it actually is. But Hume, with all his acuteness of intelligence, did his work as a man whose first love was fame, not as a man who had devoted himself to the service of ultimate truth; and after his day the school, unable to learn the lesson that looks out from his pages, went on with the old watchwords, the old point of view, the old method. The second instance is a work vaster in design, nobler in spirit. In his encyclopædic view of the embodied reason which is the structure and the history of the world, Hegel carried forward to its due use as a world-principle that synthetic character and activity of intelligence which Kant in his own rigid and cramped way had brought forward in inquiring into the possibility of human knowledge. But the third-earliest of the three in time and moving in the atmosphere of a more primitive type of thought-was in many respects the most striking of all. Once in the history of the Western world, and once only, the leaders in thought and science broke deliberately through the continuity that links together the successive generations, and turned with disgust and anger from the results accumulated by the labour of the ages gone. In dealing with the highest problem of science, they would return to the very beginning and by the use of a new method would comprehend nature and penetrate to the truth concerning man. ${ }^{1}$ Such was the Cartesian attempt. But the full significance of the Cartesian method and the Cartesian categories was not worked out by Descartes himself. Geulincx, and the great name of Malebranche, mark further stages in the process by which the endeavour initiated by Descartes entered into possession of its own meaning. But the man to whom it was given to complete this process-the man who spoke the last word of this philosophical school, and made clear to the world for ever the final outcome and meaning of the Cartesian way of attacking the ultimate problems of science-was Benedict de Spinoza, a solitary man who was pure in heart and cared nothing for wealth, or social position, or fame, but loved truth, and for its sake was willing to be driven from his father's house and to earn a sternly simple fare by grinding lenses.

1 Cf. supra, p. 59. 


\section{THE METAPHYSIC OF SPINOZA}

It is true that the Cartesians were not aware of this relation of Spinoza to their school; true that Spinoza himself was scarcely aware of it. Malebranche is ready to anathematise Spinoza; and Spinoza occasionally protests in very sharp terms against this or that particular doctrine of Descartes. But that does not alter the case. All these men of thought were seized, as Kuno Fischer so aptly reminds us, "by the powers of whom it is said nolentem trahunt"; though they themselves did not know it, they were all labouring at a single task, and moving through the different stages of a single journey.

\section{II.}

"This lonely man it was, then, who spoke the last word of that type of thinking with which the modern world began when it revolted from the mediæval and proceeded to build anew the house of life and of thought. "That last word he spoke so resolutely that the world was enabled - or rather compelled - to pass on to those other thoughts in the midst of which we men of to-day live. So that Spinoza is one of the founders of the present-day world; and yet he stands far from our daily companionship. He helped to make us what we are; and yet to most of us he seems unspeakably remote, a solitary and monumental name, a vast but far-off power.

But there is another interest, if possible one still deeper, connected with the name of Spinoza. In thought-and in life-there is, as already we have seen, ${ }^{1}$ a division profounder than that into historical stages and schools; there is a distinction of fundamental tendencies, an antithesis, simple, radical, primitive, which at once underlies, and expresses itself through, the differences of the schools; the distinction, namely, between the thought (and the religion) which in finding God finds the light and truth of the world, and that which, to find God, leaves the world behind. And what gives to Spinoza this second and profounder interest is a twofold relation which he bears to that elemental and radical antithesis. On the one hand, he is the last of the very few supremely great voices through whom that side of the antithesis for which the modern world thinks it has no place

1 Supra, p. 7 seq. 


\section{THE METAPHYSIC OF SPINOZA}

has found express, and at the same time orginal,1. formulation for itself. But, on the other hand, while the tendency in question secures in him this express and unmistakable utterance for itself, he is forced to go beyond it, and so in his system it is seen standing face to face with its great and age-long opponents.

Such is the historical position of Spinoza. Of the two relations which make up that position-the relation to the Cartesian philosophy, the relation to Mysticism-the one mentioned last is logically the first, in the sense that that elemental antithesis is deeper than the division into historical periods and schools. So that, in seeking to view Spinoza in his historical position, it is to that fundamental distinction that we must turn first. And to understand it as it appears in Spinoza, we must first endeavour to understand it as it is in itself and for its own sake. To do that, we must consider two things: first how it arises; secondly, its chief appearances in history.

\section{III.}

In attempting to understand how that distinction arises we have to consider, first what the fundamental instinct and presupposition of all scientific work is, secondly the two ways in which that instinct may fulfil itself when science reaches its final or metaphysical stage. First, then, the endeavour of any particular "special science" is to find unity of principle in the phenomena with which it deals. And the endeavour of science as a whole-or, in the words just used, the endeavour of science in its metaphysical stage-is to see the world as one. It is true that in this, its last and highest task, science sometimes falls by the way; and falls with so decided a motion that it remains fixed where it has fallen. That is to say, certain metaphysicians and certain schools of metaphysic, regard their work as

1 Original, not as standing out of relation to earlier men of thought-that were to deny what has just been affirmed-but as being the outcome of the independent working of Spinoza's own mind upon the material furnished to it, whether by previous thinkers or by his own experience of life. The word is inserted to exclude teachers such as Schopenhauer, whose formulation of this same tendency can scarcely be called an original movement, but is rather a revival of an ancient system and a delivering over of the Kantian epistemology to it to be its handmaid. 


\section{THE METAPHYSIC OF SPINOZA}

completed before they have reached a One at all. They remain to the end with a multitude of eternal "distinct existences" on their hands. It is true, too, that systems formed in this way-monadologies, sensationalisms, atomisms-have taken a very great place in the history of philosophy. And still farther, they have been very useful there. But the true nature of that usefulness should be recognised. The man who understands that the search of science, from its lowest stage to its highest, is a search after unity, will also understand what the genuine significance is, of a pluralistic termination of the scientific endeavour; namely, that the science which so terminates has taken as a highest and ultimate category some principle which is not powerful enough to link together the stubbornly diverse factors of the world. That is to say, the pluralistic systems are reductiones ad absurdum of the methods which have produced them. And it is for this very reason that the usefulness of these systems in the history of philosophy has been so great. They have been stages on the way to insight. At certain times they have made clear-to those who could understand-the inadequacy and inner hollowness of some popular school or of some trusted method. At other times they have deepened the problem for some too hasty monism, setting over against its thesis a stubborn and resolute antithesis. In a word, they have been steps, worked out often with great keenness and acuteness, in that long dialectic process which is the history of philosophy.

But, as already has been noted, the very nature of the attempt of science-the very nature of such a thing as a search after law in the diversities of the world-involves that, unless that scientific attempt is to be false to itself, its last and highest view of the world must be a view in which the world is seen as one. So that, granting to the full the usefulness of the pluralistic systems in the dialectic development of philosophical insight, it remains that in them, as was said above, the scientific endeavour is seen "falling by the way and remaining fixed where it falls." But the radical and elemental distinction which we are now concerned to understand, is a distinction between the systems of philosophy which, with all their errors, have not erred in that fashion, but have pushed their way through to a 


\section{THE METAPHYSIC OF SPINOZA}

unitary view of the world. And the distinction consists precisely in the way in which they do thus push their way through to a One.

For both sides take their rise in a profound discontent-sometimes almost purely intellectual, sometimes moral or religious as well-with the manifoldness, the changeableness, the dividedness, the imperfection and disorder, of our everyday experience. But the one side proceeds from the unsatisfactory Many to a One whose distinctive character is simply this-that it is not the Many. While the other side proceeds from the unsatisfactory Many to a One which is the Many over again-but the Many as truly or adequately known, and in the light of that adequate interpretation seen to be no longer unsatisfactory. On the former view, manifoldness and dividedness are inconsistent with the One; on the latter, they are necessary to it. To the former, the infinite excludes finitude; to the latter, it mediates itself through finitude-is an infinity of determinations. To the former, again, the eternal is no home of change and of time; to the latter, it is at once the home and the law and the informing spirit of time and of the changing things of time. To the former, God is all in all; the world can be only a shadow, from which the wise man will set himself free in order that in God he may become at one with reality. But to the latter, the world is the process of the realisation of divine ends, and thus is in organic connexion with God and is a true field of labour to the sons of God.

Philosophy, in a word, is the apprehension of the unity and eternity of all true existence. But men differ in the way in which they pass from the diverse and changing elements of their daily experience to their vision of that unity. To some it is a One which is not the world, and in whose presence the world fades away. To others it is a One which fulfils itself through the whole system of the changes and diversities of the world; it is the light and the life of men, and of the whole universe of experience. In both cases the effort of man is to see truly; and to see truly by seeing under the form of eternity. But upon the one view, the things of to-day and to-morrow cannot endure the light of eternity; they vanish as dreams vanish, when the soul is aroused from troubled sleep and the delusions of the night fall from it and are gone. While to the other view the 


\section{THE METAPHYSIC OF SPINOZA}

things and interests of time lose indeed their fleeting and self-centred individuality; but only to be seen in their truth as elements of eternity. They die, but in dying find a life over which death has no power; for now they live not unto themselves, but in the eternal and unto the eternal. To this type of philosophy, the particular things and interests of our experience, so far from being mere appearances professing a reality to which they have no claim, are in truth more real even than they seem to be. So that this philosophy is a philosophy humane and kindly. It is hospitable to all forms of being -though it has its sternness in insisting that each shall recognise its place and devote itself to its own function. Every lineament in the face of nature is dear to it; but its special delight is with man and his history. The labour of man, the achievement of man, the glory and the tragedy which are never far from any man's heart-it is never weary of attempting to set these in the light of eternity and to show them transfigured by that light. But the philosophy which stands over against this can give no such welcome to all the halfearthly half-heavenly content of our life. Not that it does not love men. In its greater historical forms it has loved men with the profoundest and most passionate of all the forms of love-that overwhelmed with the sense of tragedy; its love being not that of delight, but that of a great pity for the hapless creature whom it saw losing himself in things which, not being God, are nothing and worse than nothing. But the very principle which gave such passion to its love for man made it stand aloof from man's ordinary life. It made its home neither with his daily affairs, nor with the humanities, nor with nature. To pass from its great opponent to it is as if one passed from Athens-from the thronged harbours of the Piræus, from the voices of statesmen and sophists and tragedians, from the gatherings of men who delighted in life and in one another and in the exercise of all the powers that their natures included-to some solemn temple of Lacedæmon, standing apart in grave strength and austere majesty, changeless from age to age, while in hollow Sparta the generations of mortal men hastened to death.

This, then, is the deepest of those divisions that have sundered 


\section{THE METAPHYSIC OF SPINOZA}

into diverse schools and tendencies the long attempt of man to understand himself and his world. It is a first and fundamental distinction which the student must understand if he is to understand the history of philosophy at all. That history seems crowded with a multitude of structures; and the difference of these from one another seems as great as their internal complexity. But when the investigator digs down into them, what he comes upon at last is one or other-more often both-of the two great tendencies now before us. These are elemental in character, primitive, simple; and they are of immeasurable antiquity; for they are as old as the dissatisfaction of the human soul with its imperfect being and with its momentary and transient experiences. Their opposition has moulded the whole dialectical evolution of man's endeavour to understand his life. From the beginnings alike of religion and of reflective thought they, like inner forces, have guided the main currents; and have determined the proportions of the greater systems. The history of their warfareand of their combinations with each other-is, on its practical side, the history of the religious life; and, on its theoretical side, the history of philosophy.

So long as we understand the essential movement of these two tendencies, it matters little what names we give them. Some designations, however, we must have, if only for convenience of reference. The broad contrast between the two, as tendencies or methods, may be indicated by the terms "abstract" and "concrete"; or by the terms "analytic" and "synthetic"; or we may borrow terms from the older theologians, and call the one the via negativa, the other the via affirmativa. To find names for the views of the world which arise from these tendencies is on the one side fairly easy, on the other somewhat difficult. The philosophy of the via negativa-that which in moving toward the One denies the Many-may, when it confines itself to pure theory, be called "abstract pantheism," or from another point of view "acosmism." But when it goes beyond pure theory, and is

1 A term accurate in the sense of giving a negative name to a negative movement of thought. Yet (leaving aside Hegel's appropriate use of it in replying to those who accused Spinoza of Atheism) it jars upon one who remembers how exceedingly positive is the impulse-the impulse after reality-out of which this negative movement of thought has so often arisen. 


\section{THE METAPHYSIC OF SPINOZA}

at once a view of reality and a way of life, it is Mysticism-the pantheistische Mystik of that saying of Rothe which Dr. Martineau put upon the title-page of his Spinoza,

\section{Der pantheistischen Mystik ist wirklich Gott alles, Dem gemeinen Pantheismus ist alles Gott.}

And having the general name of Mysticism, we need scarcely, for our present purpose, concern ourselves with names for its various types. For while it is true that the points of departure from which men have proceeded to an abstract One are very various, yet the conclusion itself, when reached, can scarcely be said to have diverse forms. To that "lion's den" many paths may lead-some purely theoretical, some religious-but to all of them it is a lion's den. There are different kinds of Mysticism only in the sense that men come to Mysticism along different ways, under different impulses, in different tempers. But on the other side the subdivisions are numerous and of the utmost importance. For here the Many are not lost in the One, but preserved in the One. The One is the source and constitutive principle of the world-the principle of connexion which links its many factors and elements together into one orderly system. Hence, what the nature of that connexion is (and consequently what the nature of the world, and what the nature of our life in it) depends on the nature of the One. And that nature may be apprehended upon many different intellectual levels-i.e., by many different categories. For reflective thought began with simple categories which could not do justice to the positive relation between the details of the world and their supreme and eternal principle; and from these, advanced to categories more concrete and therefore at once more comprehensive and more penetrating. We thus get an ascending series of views, less or more adequate according as the category employed is less or more adequate to that which is to be apprehended. It may be broadly stated that the lower forms of these are dominated by the idea of necessity a tergothere is somehow a beginning, or cause, or substance, and from it things "follow" or "flow down," the course of the flow being absolutely determined by the nature of the cause or source; while the higher are dominated by the conception of spirit, and the consequent 


\section{THE METAPHYSIC OF SPINOZA}

conceptions of teleology, and of a rational necessity union with which is true freedom. To those lower forms-since in the last analysis they must regard all particular things as the modes which in their totality make up the eternal One-we might apply Rothe's term, gemeiner Pantheismus; or we might use some such name as "naturalistic Pantheism." The higher forms are usually denoted by the name Idealism, in its greater sense as defined on a previous page ${ }^{1}$ though, as there noted, even in Idealism we have to remember the distinction between a more concrete form which believes that the eternal, rational spirit fulfils its purpose through the whole process of the world, and a more abstract form which can see God only in pure reason, and is obliged, therefore, to condemn the world of the senses. ${ }^{2}$ With these subdivisions, however, we are not directly concerned at this point. What we must do here is to fix firmly in our minds the original and fundamental distinction itself between the tendency which is abstract and negative, and that which is affirmative and concrete.

1 Supra, p. 11. Cf. infra, pp. 209, 210.

2 To the student of "Logik"--the science whose business it is (or was) to deal with the categories and hence to arrange the various types of philosophy in the order of their advance from abstractness toward concreteness-this matter of classification will of course offer no difficulties. All these tendencies and types can be arranged as stages in a single process of logical evolution. The first-the thorough carrying out of the via negativa-stands at the beginning where the categories employed are altogether abstract (the categories of pure Being). The third stands at the end, where a highest category has been gained which is altogether concrete (Absolute Idealism). While the remaining forms are the stages which constitute the long road between-one of the most striking of these being that which, as its highest category, uses the conception of causation (whether physical or logical) in such a way as to give us a view of the universe as a great process of necessity a tergo. Those intermediate types have the common characteristic that they have not felt the pressure of the problem of the self; they have not grasped the fact that "things" (extended things as much as any other) are objects existing for and through a self which holds together many "experiences" in the unity of one experience; to them, in other words, man is simply a part of nature; whatever principles are adopted as explaining the things which seem to exist in their own right in space and time, are ipso facto adopted as explaining man. And it is when the pressure of the problem of the self (usually in a special form-the problem of the possibility of knowledge) is felt, that philosophy passes upward from those intermediate types to the Idealistic. In the examination of human experience a synthetic principle, self-conscious, self-distinguishing, self-determining, is found; and such a principle furnishes the key for the solution of the problem how the many facts and beings of the world, without losing their particularity, can be linked together into one reality. Self-distinguishing and self-determining spiritso science finds at the end of its long ascent-is the principle of unity-in-diversity which enables us to view the universe as one, without abstracting from, or condemning as illusion, that manifoldness of existence which is found, not only in the multiplex life of nature, but also in the divisions of the intellectual and moral and religious life of man. 


\section{THE METAPHYSIC OF SPINOZA}

In the thought of Spinoza both these tendencies are present. The former-the tendency to the via negativa-is not only present in him, but is that first and fundamental thing in his thinking with which the student must begin if he is at all to understand Spinoza as Spinoza actually was. But in that large and sincere and open mind, the unquestioned domination of the negative tendency was impossible. To such forms of the other tendency as could enter his field of thought he gave fair hearing, and dealt as he was able with the problems which these forced upon him. Of this, the result was not so much the renunciation of the negative tendency, as the setting of the other beside it; or rather the setting of two forms of the other beside it. For, as we shall see, he set beside it, in fully articulated form, what on the classification noted a moment ago would be called a lower type of the positive or synthetic view. But then in certain connexions he was driven even beyond that, and worked out doctrines which cannot indeed be called a system, but are prophetic hints and glimpses calling for the highest type of the concrete view, i.e., for Idealism. In order, then, to understand him as he was and to follow his thinking along the line of its own journey, we shall study first how he was led toward the negative or mystic conception of reality, and then his advance from it to the other points of view just spoken of. But-as was noted a moment ago-to study intelligently the negative tendency as it is in Spinoza, it will be wise first to study it on its own merits and for its own sake. And that can best be done historically.

IV.

In the age-long effort of man to find out what he is, and what his experience means, and what the true way of life for him is, this abstract or negative way of thinking has shown itself times innumerable. In some cases it has played the part of a Nemesis of thought, appearing unbidden in the systems of those who face with inadequate categories the ultimate problem of science. ${ }^{1}$ But these cases need not be dwelt upon here. For, in the history of man, it has had a greater

1 A remarkable instance is the case of the development from Sir William Hamilton through Dean Mansel to Mr. Spencer. 


\section{THE METAPHYSIC OF SPINOZA}

part than that to play. Strange as the fact may seem, this austere and abstract tendency, which has for its goal a formless Absolute and an eternity devoid of time, has not only dominated the thought, but has governed the life, of whole races and nations. Stranger still, it has at times regenerated religion, and broken up spiritual stagnation. It has even helped to shatter political tyrannies. And as one might conjecture beforehand, a tendency that has taken so great a place in the life of man has not wanted for expression in the works of the great masters of systematic thought. Sometimes it has ruled half the divided heart of a supreme teacher. Sometimes, on the other hand, from a method or a point of departure in which it lay latent, it has worked its way, with a logic as inevitable as the decrees of fate, to its full meaning; and then has shown itself as the fundamental and controlling factor in the thought of some great man, or some great school, or some remarkable age.

The cases of the former kind are of the very deepest interest. They stand central in the historical development of philosophy; one might almost call them its great ganglia. Here, however, it is possible to refer only to two of these. The first is the greater. In the thought of Plato the negative tendency is present, confronting the affirmative; and there, in the presence of its opponent, it takes on, more than ever before in the history of man and more than ever after, the characters which are native to it - the solemnity, the unearthly splendour, the austere Lacedæmonian grace, appropriate to the vision of an eternal being in whose presence the weaker things of time pass away and are not. But while it is present, and knows itself, it cannot prevail. For in Plato, as in all the great cases of its occurrence, the negative tendency takes its rise in that which is the genuine beginning and the genuine inspiration of all science, and of all philosophy, and in one sense of all religion; namely, in the instinctive search of the spirit which is man for the abiding and the unchangeable; in the passion for the eternal. But of the men who are thus animated by the passion for the eternal-the men who, as we are wont to say, are "not of this world"-there are two classes. Some who are "not of this world" are so in the literal sense. So far as they can, they walk without transgression in the way of the negative theology. Their journey 


\section{THE METAPHYSIC OF SPINOZA}

toward their home in God, is a journey away from this world. But others, who are "not of this world," are for that very reason all the more truly citizens of this world. Their knowledge that their dwelling-place is in the eternal makes all the profounder and all the more genuine their citizenship in that temporal order which is "a moving image of eternity." 1 And as between these alternatives Plato's position was peculiar. A certain Dorian quality of soul struggled in him with an Ionian intellect and with Athenian training and tastes and interests. And the practical tragedy in his life ${ }^{2}$ partly withdrew him from the world, partly made him all the more passionately earnest about the reformation of the world within the forms of its present order. The negative tendency lay very close at his heart; yet, upon the whole, it is the other that prevails in his philosophy. The Ideas remain determinate forms-and determinate rational forms. The One (i.e., the Idea of Good) does not by its presence condemn to unreality the lower Ideas in their individual distinctness; nor for the apprehension of it is a type of consciousness above the rational required. And even more than that can be said. Of the two interpretations of Plato, that which sees the Ideas as in organic union with man's present world and present experience, is really more true to Plato than that which sees the Ideas as dwelling altogether apart from the world. What Mysticism does for Plato is, not to overcome him, but rather to give loftiness of soul, and a certain undernote of tragedy, to his Idealism. Indeed his thought as a whole is an example of the fact that a great and complex process often takes on a wider movement, a new and higher order of power, when a negative element enters among its constituents.

The other case lies close to ourselves. A negative movement of thought is present in the very system in which the metaphysic of the present day recognises its proximate fountain-head-in the critical philosophy of Immanuel Kant. But, although more than twenty centuries had intervened-some of them filled with hard thinking, others given to eager conquest of the world-yet the negative tendency is in Kant far less aware than in Plato of its own true nature. 


\section{THE METAPHYSIC OF SPINOZA}

Appearing first as a gulf between the categories and the materials given in sense-and then going on through other dualisms to that final one between the phenomena given to the understanding, and the real world which is the field of the rational will-it operates mainly as a potent source of difficulty and confusion; and the first labour of the followers of Kant was to overcome it, so that Kant's synthetic view might be developed to its full significance.

It is hard to turn away from a more detailed study of these two cases. But they do not give us exactly what we want here at the beginning. What we need here is to see the negative tendency, as far as possible, in the purity of its type; to see it as it is in itself. What we must do is to turn to the other great class of its appearances-those in which, from the method or the point of departure wherein it is latent, it advances with uninterrupted logic, moving with its own motion, working out its own dialectic, until, as one may say, it possesses the whole field.

Of such cases there are three in particular, which (specially when compared with one another) show what this tendency is; show what that meaning is, which it has in it at its beginning and develops in its course. One of these is found in Greek thought before the problem of the self had come clearly to view. Here the tendency shows itself in a strictly theoretical form. It gives, as one may say, a sketch of itself in its purely logical outline. But it did not-in that land and at that age, it could not-enter upon the full work of a philosophy. It neither became a guide of life, nor faced the full weight and power of its own theoretical shortcoming. The second is much earlier in date; but much fuller in articulation. Among the Hindus the negative tendency not only works itself out with a singular completeness of logical development, but also undertakes what has just been called "the full work of a philosophy." It puts its shoulder to the wheel. It acts as a guide of life, and builds up an ethic and a philosophy of religion. While in the third case-the Neo-Platonic-it is seen at last recognising its great theoretical difficulty, and erecting, in the effort to overcome that difficulty, a structure of almost monstrous vastness.-And, as we shall see, there is a fourth case, which scarcely adds any new logical factor, but which so well sums up in itself the main features of the 


\section{THE METAPHYSIC OF SPINOZA}

three cases just mentioned, that it will be worth our while to take note of it as we pass from these historical references to the direct study of Spinoza.

What we are to see in the Greek case is the pure science, the pure logic, of the matter, given in a very brief and elementary form, but with perfect clearness. This case we shall best understand by considering the logical position in which men inevitably found themselves when they first attempted to be scientific in their thinking about the world. First, the instinct after unity, the sense of the oneness of all existence, is present; present at the very beginning, for without it there could be no such beginning. It may be unrecognised and unreflected upon; but without its implicit operation there would be no such thing as the search after scientific explanation at all. The mind would simply rest each instant in the particulars of that instant. But, secondly, the category that can affect the unification of this most complex world, must be a very complex and difficult category. But such a category is not present at the beginning. Or rather, it is present only potentially and shows itself only in flashes of prophetic intuition. As a clear instrument of the reason, employed in building up systematic and assured science, it is gained only as the result of a long dialectic labour in which category after category is entered upon, used to the utmost of its power, and finally taken up into a higher:- - until at last a category is reached by which the Many are shown as a One, with no rebels remaining outside to prove, by the very fact of their rebellion, the inadequacy of the category for its work of unification.

So then, at the beginning the demand for unity is present. But the category by which the Many can be seen as One, is, in the sense just mentioned, not present. What almost inevitably results is a stage of thinking in which the One runs away with the Many-or to speak more decorously, in which the Many are lost in the One. This whelming of the Many in the One is likely, indeed, to take place near the beginning rather than at the beginning. Near the beginning; for there the categories are simple, abstract, inadequate. But not precisely at the beginning. For the denial of the manifold involves two things which 


\section{THE METAPHYSIC OF SPINOZA}

at the very beginning can scarcely be present; first, as we shall see presently, an unflinching, uninterrupted consistency in carrying a given category to its extreme and absolute application; and secondly, a high degree of speculative courage. But as soon as the scientific intellect has taken on some considerable impetus and has come to feel tolerably sure of itself, then we may look for such an affirmation of the unity of being as makes its manifoldness a mere illusion.

Among the Greeks-in whose early men of thought the pure intellect, serene and undistracted, enslaved neither by force from without nor by superstitious fears within, stood free to work its way without interruption through the dialectic of its categories-this tendency came to the forefront just in the place indicated. The name connected with its clear and full emergence is the great name of Parmenides.

If we consider the exact situation which Parmenides faced, we shall see both how clear his logic was, and how absolutely inevitable was the conclusion to which he came. He stood face to face with the particular things of the world, and these were not self-intelligible. Of this plant, this cloud, this cliff that the sea is wearing down, one has to say, "It is." But there was a time, and there will again be a time, when one, if present, would have to say, "It is not." But there is no rest for the intellect in such things. They do not stand upon their own feet. They are and they are not. What is wanted is something which will supply a footing to these things, and which at the same time will itself have at least two characters. First, it must be something of which you can in the fullest sense of the words say that it is:-at no time, in no place, under no circumstances, must you be able to say that it is not. Secondly, it must be something which is one with itself. That is, it must always remain itself throughout all its work of making possible these particular and transient "things" and this changing order of "nature." If, for instance, it be something which condenses itself into these stones and rarifies itself into that vapour, it must still remain itself throughout all those transformations. And this second character follows directly from the first; the "It remains itself," from the absolute "It is."

The first Greek men of science faced this problem as well as they 


\section{THE METAPHYSIC OF SPINOZA}

could. They used such intellectual instruments, such categories, as they had. And the category which they had was the first and simplest of all our categories-that of Being. This category they used in specific and very naive forms. But its essential character was always the same:-Being is that of which you can simply affirm that it is. Soon, however, these men of science found themselves in difficulties of a most serious character. Their category turned a very unkindly and very uncompromising face toward the actual existences of the world. They were-if the illustration be not too profane-somewhat in the position of a man who has discovered that space is two-dimensional. If you have found that space has but two dimensions-that all spatial reality exists in a plane-you must leave off tying sailors' knots and must have nothing more to do with the various gymnastic feats which involve motion in the third dimension. And if you find yourself still doing these things you must declare that really you do not do them; that in truth they are but illusions. For any motion is either in that plane, or out of it; and if it is out of it, it is unreal. Just so it turned out to be with the category of Being. These things of time and of sense are continually changing, continually swaying back and forth between "is" and "is not." But Being is. In it there is no " is not." In a word, there is no place in it for change and for things that are subject to change. And if you try to escape the difficulty by making the conception of Being into the conception of Substance; if you try to keep both the Being and the things, by viewing the Being as the substrate of the things: you help yourself not one whit. The old difficulty simply recurs. Here is this particular thing. It either has Being or else it has not Being. If it has Being, then it cannot have any sort of "is not" about it-for how can "is not" get into the pure and absolute "is"? That is to say, it cannot, among other things, have any change in it. But it changes even while we are speaking about it. Therefore it has not Being. It is nothing at all. If you appeal to your sense-experience, your sense-experience must be declared to be at once an absurdity and an illusion. Nor can you be permitted to attempt an escape by setting up a distinction in the thing between Substance and Accidents. For precisely the same test banishes the Accidents into nothingness. 


\section{THE METAPHYSIC OF SPINOZA}

So that when, these early men of science attempt to understand the world by means of the only categories they have securely grasped - those of Being or of Substance-the solution, as soon as its logic is worked out, swallows up the original problem. On the level of those categories, the assertion that Reality is, involves the assertion that it is One, and that the Many and the Finite and the Changeable are not.

The foregoing is simply the argument of Parmenides stated in general terms; $;$ and of course with this difference that Parmenides neither had, nor could be expected to have, any suspicion of the possible inadequacy of his categories. He used his categories in all good faith. He saw that from their point of view the disjunction of being and non-being, of "is" and "is not," is absolute. He saw that this again involved that reality is One, and its apparent manifoldness an illusion. And this he stated in a way which is not merely clear and convincing, but is absolutely final:

"One path only is left for us to speak of, namely, that $I t$ is. In it are very many tokens that what is, is uncreated and indestructible, alone, complete, immovable, and without end. Nor was it ever, nor will it be; for now it is, all at once, a continuous one. For what kind of origin for it will you look for? In what way and from what source could it have drawn its increase? I shall not let thee say nor think that it came from what is not; for it can neither be thought nor uttered that what is not is. And if it came from nothing. what need could have made it arise later rather than sooner? Therefore must it either be altogether or be not at all. Nor will the force of truth suffer aught to arise besides itself from that which in any way is. Wherefore, Justice does not loose her fetters and let anything come into being or pass away, but holds it fast. . . . How then can what is be going to be in the future? Or how could it come into being? If it came into being, it is not; nor is it if it is going to be in the future. Thus is becoming extinguished and passing away not to be heard of. . . . Nor is it divisible. . . . Moreover it is immovable. . . . without beginning and without end; since coming into being and passing away have been driven afar off, and true belief has cast them away. It is the same, and it rests in the

1 “In general terms"-for Parmenides envisaged reality spatially. Cf. p. 131, note. 


\section{THE METAPHYSIC OF SPINOZA}

self-same place, abiding in itself. . . . And there is not, and never shall be, any time other than that which is present, since fate has chained it so as to be whole and immovable. Wherefore all these things are but the names which mortals have given, believing them to be true-coming into being and passing away, being and not being, change of place and alteration of bright colour."1

"Being is One and is self-identical; the many are not." So stands the conclusion of Parmenides. But the important point for our purpose is to note how absolutely logical, how absolutely consistent and consequent, is the argument by which he reaches this conclusion. He stood within the science of his day and accepted its procedure. But he saw with thorough clearness what the ultimate meaning of that procedure was. And this he stated in a form impressive, complete, valid for ever. ${ }^{2}$ Little was left for his younger followers to do, save to round out the system on its polemic side by showing into what absurd positions men get themselves when they hold to the reality of the Many, and to the truthfulness of the senses.

Early in the course of Greek thought, then, the negative tendency stated itself with intellectual completeness and finality. And yet it did not do among the Greeks the full work of a philosophy. It did not enter upon the guidance of life. From the day of Parmenides onward one does not find the most earnest men among the Greeks being led by it to have done with the illusion of the Many, and to seek the true fulfilment of their being in a changeless and ineffable One. And the reason is plain. It consists partly in the fact that this philosophy, as a philosophy, was outgrown at last by the bringing forward of more adequate categories; and partly in the character of

1 Burnet, Early Greek Philosophy (1892), pp. 185-187.

2 The statement in the text deals with the abiding significance of Parmenides' argument, as a purely intellectual form of the logic of Mysticism. Of course, with Parmenides, as with most men who stand early in great histories, we must distinguish between the atmosphere in which an argument moves, and the essential significance of the argument which moves in that atmosphere. The atmosphere in which Parmenides' argument moved, was one of naive Realism; he envisaged his One as a corporeal sphere ; and in doing so, did not quite carry out his own principle (v. Burnet,pp. 342, 343, \& 141). But his argument itself, in its use of categories, in its movement from conception to conception, goes beyond all naive Realism; goes beyond all Realism of any sort, and leads straight toward Mysticism. 


\section{THE METAPHYSIC OF SPINOZA}

Greek life. In the life of the Hellenes, perfection of body and power of soul answered to fulness of opportunity. They lived under the clearest of skies. They were served generously by their land and by their sea. They had, among their inherited treasures, the "greatest births of time " in literature and in art, and they were engaged almost daily in placing beside these, companion-pieces that were worthy of thiem. Life they knew and the joy of life, and over its resources exercised a supreme and easy mastery. Nor did they esteem their life the less, that the Mede and the Canaanite had appeared among them, and Marathon and Salamis and Himera had become names for ever. Such a race, living such a life, was not likely, till its greater day was done, to furnish apt pupils for the lesson that the thronging interests of life are vanity and illusion, and that wisdom lies in withdrawing from them and seeking rest in a reality which knows neither change nor manifold.

But there was a race whose life had come to be burdened by the weight of an immeasurable and hopeless pain. And there the thinking that walks in the via negativa entered upon the full function of a philosophy. It gave to the generations of a great race their theoretical view of reality; it shaped-and it shapes-their morality and their religion. Hegel, thinking of the spirits of the nations as existent and particular individuals, tells us that they stand around the throne of the universal spirit, the spirit of the world, as perfecters of its actuality and witnesses and ornaments of its splendour. ${ }^{1}$ Each race, like an attendant spirit, fulfils by its intellectual and by its moral labours, its part in the one work of world-history. In this great division and delegation of the tasks of world-history, it would almost seem as if the one specially committed to the Hindu race was the full development through all its stages-was the full articulation both as an intellectual and as a moral system-of the philosophy of the negative way. The steps in that long labour of thought by which this was accomplished we have now to trace.

1 Philosophy of Right, $\S 352$; cf. $\$ 340$. 


\section{THE METAPHYSIC OF SPINOZA}

\section{$(\beta)$}

The first step takes us back to the very fountain-head of the science of the Aryan peoples. The Vedic poet stands where all orderly human science stood at its beginning. He stands face to face with the facts and forces of nature-with sky and sun, storm-wind and dawn; and he feels that these, as he finds them, are not self-intelligible; he feels that, as they stand, they do not exist in their own right. And the first step which he takes in healing this unsatisfactoriness of the facts present to him, is one in which the scientific instinct and the religious instinct go hand in hand. He personifies those facts and gives to them, as thus personified, the attributes of deity.

But in connexion with this, the Vedic poets did one of the most remarkable things in human history. What this was, can best be shown by contrasting the two great lines of thought that took their rise from the original homeland of the Aryans-the Greek and the Vedic. The Greeks very early separated their gods from the natural phenomena of which they were personifications, and humanised them - gave to them abiding individualities, clear, definite, characteristic, personal. ${ }^{1}$ While this remains the case, the gods, whatever they may be to the religious consciousness, are of little value to the scientific or philosophic consciousness-the consciousness which seeks to make the world intelligible and needs principles of explanation for doing so. If indeed an advance toward unity were to be made, by making some god supreme-whether Zeus or 'Ava' $\gamma$ w $\eta$ or Erinys-then there would be at least a possibility of the scientific consciousness finding the principle of unity that it needs. But such an advance the early Greeks can scarcely be said to have made. The consequence was that the scientific consciousness had to wait for long ages, and finally, with the Ionic physicists, to make an altogether new beginning on its own account.

But when we turn back to the Vedic line, we find something quite different. It has been pointed out times innumerable that in the Vedic hymns whatsoever deity the poet addresses is viewed for the time being as God, supreme, unlimited, absolute; and this even when other 


\section{THE METAPHYSIC OF SPINOZA}

deities are being at the same time mentioned by name. Varuna, for instance, is addressed as Lord of all, Lord of heaven and earth, upholding the whole order of nature, and guardian too of the moral order of the world. The breaking of his laws is sin. The penitent sinner is to pray for mercy to him. But presently Indra or Agni is addressed in the same way.

This fact is one of the commonplaces of present-day knowledge. But what has not always been made so clear is the mental condition out of which it arises. What it means is this: the Vedic poet, however religious he may be, has never ceased to have that in him which is nothing other than the genuine spirit of philosophy, nothing other than the genuine movement of the scientific consciousness. He feels, no matter how dimly, the oneness of nature. Some one principle, he feels, some one power, is expressing itself through all this variety of wonderful and appalling phenomena. But the only forms which he had at his command for purposes of scientific expression, were those forms which he had struck out for himself by personifying those very phenomena-Indra and Agni and Varuna, Ushas and the Maruts, and the rest of Yâgnavalkya's "three and three hundred, three and three thousand" gods. ${ }^{1}$ But then comes the trouble that no one of all these forms is adequate to the expression of the principle or power which the Vedic thinker, dimly enough at first, but with a demand that grows continually clearer, is groping after. No one of them-for it expresses itself in them all; of all of them it is the source. And so the first expedient is to use all those forms, now one, now another. A sage, Yâska by name, who lived many centuries later, puts the logic of the case into a sentence-It is owing to the greatness of the deity that the Divine Self is celebrated as if it were many. ${ }^{2}$

But such a procedure has an almost inevitable logical outcome. As time goes by and reflective thought comes forward, while poetic intuition and poetic nature-worship recede, two things come into ever

1 "How many gods are there?" asks Vidagdha Sakalya of Yâgnavalkya. The first answer is "three and three hundred, three and three thousand." But this number is steadily reduced-to thirty-three-to one and a half-finally to one. This one is Bráhman and his name is "That."-Brih. Upanishad, III. 9. 1-9. (Sacred:Books of the East, vol. XV., pp. 139-142.)

2 Max Müller, Three Lectures on the Vedanta Philosophy, (London, 1894), p. 27.Yâska lived circa 500 B.C. 


\section{THE METAPHYSIC OF SPINOZA}

clearer consciousness. First, that what is really being sought for is One. Secondly, that this One is not to be identified with any of the forms just referred to-not with Varuna the Heaven, nor with Indra the giver of rain, nor with Agni the fire, nor with the appalling Maruts, the storm-winds. The oneness will be ever more strongly and clearly insisted upon. But to any definite determination or qualification of it, the answer will come to be-and did come to be- "Nêti, nêti." In a word, the goal that lay straight ahead was an abstract One and an illusory manifold. And to this goal the thinkers of India advanced with a logic that neither flinched nor failed. "Sir, tell me Bráhman," said Vâshkalin. Thereupon Bâhva became quite still. When Vâshkalin had asked a second and a third time, Bâhva replied: "I am teaching you indeed, but you do not understand. Silent is that Self." 2

Such was the first great step taken by the thought of India. Its inner movement is not greatly different from that which we met with in the case of Parmenides. Its search after the One moves in the logical region of the category of Being. And it does what on the level of that category is inevitable. It absolutely disjoins "is" and "is not."3 And it is thereupon obliged to exclude from reality the determinations which involve an element of "is not." But the next great step which the thought of India took, goes far beyond this, and is of incalculable importance. It builds the bridge which the metaphysic of the via negativa needs, to enable it to advance to the work of constructing an ethic and a theory of religion. In dealing with Par-

1 "Neti"-it is not thus. See Brih. Up. II. 3. 6. (Sacred Books of the East, vol. XV., p. 108): III. 9. 26 (ib. pp. 148, 149): IV. 2. 4 (ib. p. 160): IV. 4. 22 (ib. p. 180) : IV. 5. 15 (ib. p. 185).

2 Sacred Books of the East, vol. XXXVIII., p. 157.-Cf. Max Müller, Three Lectures on the Vedanta Philosophy, p. 84.

3 " 'In the beginning, my dear, there was that only which is ( $\tau o ̀$ o $\nu$ ) one only, without

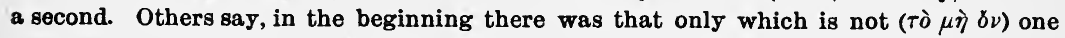
only, without a second; and from that which is not, that which is was born.

'But how could it be thus, my dear?' the father continued. 'How could that which is be born of that which is not? No, my dear, only that which is, was in the beginning, one only, without a second.

'It thought, may I be many . . ."

-Khand. Up. VI. 2. 1, 2, 3. (Sacred Books of the East, vol. I., p. 93.-Cf. Max Müller, Three Lectures on the Vedanta Philosophy, p. 35.) 


\section{THE METAPHYSIC OF SPINOZA}

menides two reasons were pointed out which prevented his philosophy from becoming to the Greek race a guide of life. Those were both, in a sense, external to his philosophy. They barred the way against it from without. But if these had both been absent, there was still a third reason, internal to the system of Parmenides, which would have tended to hold it back from becoming a guide of life. If I am convinced that the changing and the manifold are illusion; and if by actual experience I have found the life which involves these to be very evil-so evil that life and sorrow are one same thing; and if from that illusion and that evil I wish to be delivered by finding rest in the One; then, whether the logic of my philosophy allows it or not, I must believe in some sort of organic connexion between myself and the One by withdrawal into which or absorption into which I am to find rest. But such a connexion Parmenides could not assert. For, as we have seen, the problem of the self simply did not exist for him at all. To the teachers of India, however, the problem of the self became a keen and pressing one. And so they were able to make the great advance which rendered possible the application of the negative metaphysic to the burdened life of India:- - they asserted a connexion, nay they asserted an identity, between the self in man and the One which is the true and only reality.

The expedient by which this identification of the self of man with the One-with Bráhman-was effected, was very violent. But it was closely in line with the general procedure of the negative metaphysic. And not only that; but when once a race of thinkers to whom the problem of the self is present, have taken the first great step in the via negativa - have made the advance to an indeterminate Onethen this second step is demanded by an inexorable necessity. This necessity the clear-eyed dialecticians of India were neither unable to see, nor afraid to face. On the level of the categories which absolutely disjoin "is" and "is not," Being must be One; no sort of exception or division could in any way be admitted. Yet the self had taken such a place in their thinking that it could not be summarily dismissed as this fleeting cloud, or that fading plant, could be dismissed-namely, as illusion. So that the situation had come to be this.-Being is One, without division. Yet the self in man cannot 


\section{THE METAPHYSIC OF SPINOZA}

be dismissed. Then what can that self be? It cannot be considered either as a part, or as a modification, of the One. That would be to attribute finitude and division to Bráhman. Nor can the human self be anything different from Bráhman; for Bráhman is all in all, "one without a second." In a word, there is no alternative but to identify the two. And that, moreover, not in the sense of calling the human self a part of Bráhman; but in the sense of an absolute identification -the whole of Bráhman is the human self. ${ }^{1}$

But do not the manifest finitude and dividedness of our human experience recalcitrate against such an identification? Yet the identification must be made; and the thinkers who lead the way from Veda to Vedânta cut through the difficulty by a piece of that resolute surgery which the metaphysic of the via negativa knows so well how to practise. They conceive the soul as they conceive the ultimate and only reality with which it is to be identified-namely, in an abstract way. The manifold experiences of the soul, its manifold activities of thought and of sense, of memory and of imagination-these are but a veil, and behind this veil dwells the true self of which we can say nothing except that it is. The apparent dualism of the relation of subject and object, whether in sense-experience or in self-consciousness, is ruled out altogether from the true Self. " . . . When the Self only is all this, how should he see another, how should he smell another, how should he taste another, how should he salute another, how should he hear another, how should he touch another, how should he know another? How should he know Him by whom he knows all this? That Self is to be described by No, no! He is incomprehensible for he cannot be comprehended; he is imperishable for he cannot perish; he is unattached for he does not attach himself; unfettered, he does not suffer, he does not fail. How, O beloved, should he know the Knower?"?

This, too, was made all the easier by the very term which was used to denote the self or soul. The term âtman which was used to denote the soul of man, had been originally, as Max Müller tells us, " a mere pronoun free from any metaphorical taint, and asserting nothing

1 Max Müller, Three Lectures on the Vedânta Philosophy, pp. 90-92.

2 Brih. Up. IV. 6. 15. (Sacred Books of the East, vol. XV., p. 185.) 


\section{THE METAPHYSIC OF SPINOZA}

beyond existence or self-existence." It meant ipse, and as used to express the essence of man or of God, its idea was simply ipseitas. Man was Giv âtman, the living, and God was Parama-âtman, the highest ipse. And the absolute identity of these two abstract essences was not hard to affirm.

Thus, then, the great identification was made, and the "Tat tvam asi" - "Thou art it "_and the "Aham brahmâsmi"_- "I am Bráhman"-become the watchwords of this second main step in the logical evolution of the negative metaphysic in India. " . . . Therefore now also, he who thus knows that he is Bráhman, becomes all this, and even the Devas cannot prevent it, for he himself is their Self. Now if a man worships another deity [i.e., a Deity external to the Self in him] thinking the deity is one and he another, he does not know." . . He who perceives therein [in the "ancient, primeval Bráhman "] any diversity, goes from death to death."2

And with this the way was prepared for the advance to ethics and to religion. A self which could be called God, but which could also be called man, was left standing. But the finite, the manifold, the changeable, were expelled from reality and cast into the limbo of vanity and nothingness. "In one half verse," says the Vedântist, "I shall tell you what has been told in thousands of volumes:-Bráhman is true, the world is false, man's soul is Bráhman and nothing else. There is nothing worth gaining, there is nothing worth enjoying, there is nothing worth knowing but Bráhman alone; for he who knows Bráhman, is Bráhman."3

With this, then, the thought of the Vedântists went forward on its great way, to be the guide of life and of religion, not to India alone but to lands even more populous. Upon that, however, as we are chiefly concerned with the inner logical movement of the metaphysic of the negative tendency, we cannot here dwell at any length. But a hint at the vast width of that guidance and at its profound significance in human history, may be given by a brief reference to two

1 Brih. Up. I. 4. 10. (Sacred Books of the East, vol. XV., p. 88.)

2 Brih. Up. IV. 4.19 (cf. 18-Sacred Books of the East, vol. XV., p. 179).

3 Max Müller, Three Lectures on the Vedanta Philosophy, pp. 172, 173. Cf. the King's statement of the vanity of life, in the beginning of the Maitrayana-BrahmanaUpanishad. (Sacred Books of the East, vol. XV., p. 288 seq.) 


\section{THE METAPHYSIC OF SPINOZA}

things. The first of these is seen in the "Forest Schools" of Brahmanism. When a man's hair had become white and he saw his children's children, then he withdrew to the forest. The Vedic hymns which hitherto had been to him so absolutely sacred and so absolutely unquestioned, were replaced by the negative and abstract theology of the Upanishads. And instead of the careful ceremonial observances of his earlier life, and its performance of civic and domestic duties, he sought only to free himself from the personal and the individual, and thus to find his true self in the Eternal Self, in the One, in

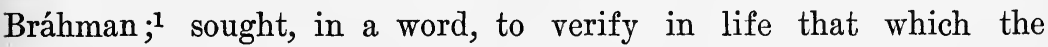
Upanishads taught him as theory-Tat tvam asi, thou art it. The second is seen in an ethical teaching which went far beyond the bounds of India. Gautama had been trained in the negative metaphysic of Hinduism. And though he spoke later like one who has repudiated all metaphysic, yet it is fair to say that his doctrine of Nirvana expresses the ultimate ethical implication of the metaphysic of the Vedânta. The very intensity of his compassion for a life which is essentially vain led him to make his moral teaching as absolutely negative as a moral teaching inspired by compassion well can be. Indeed the morality whose goal is Nirvana is so negative that there is no place in it even for asceticism; or if there is, it is only as a means in subduing Trishna. ${ }^{2}$ For the extirpation of Trishna is the cessation of the formation of Karma. And with that Nirvana is gained.

Thus in India the negative tendency worked through the process of its logical evolution and entered upon the full work of a philosophy. It seems indeed a far cry from Veda to Vedânta. The brightness of the early Aryan hymns which rejoice to watch Indra "cleaning the mountains" or " rousing his strength in a moment like the whirlwind rushing along with thundering clouds," and are glad at the presence of the Dawn, "the mother of the morning clouds, clad in her garments of light," "shining on us like a young wife, rous-

1 See Max Müller, Origin and Growth of Religion, (Hibbert Lectures), p. 364 seq. Cf. Three Lectures on the Vedanta Philosophy, pp. 19, 20.

Trishna-desire, yearning, thirst; whatever causes life to be a process of activity. 


\section{THE METAPHYSIC OF SPINOZA}

ing every living being to go to his work,"1-this seems far separated from the grey, worn thought of the Upanishads. Yet we have seen that the process which led from the one to the other was a process of thorough logical continuity. When, in a Hindu family, the young son was being trained in the strictest Vedic orthodoxy while the grandfather dwelt apart in the forest meditating upon a theology in which the Vedic deities could find no place, this was not mere inconsistency or contradiction. It was the symbol of the connexion between the early and the late stages of a single development. Indeed the Vedântists and the Eleatics are alike proofs that in all the history of thought there are few logicians so consequent, few dialecticians so strict, as those whose fate it is to conduct from its premisses to its conclusion the ratiocination of the negative philosophy.

And yet for Vedântist and Eleatic alike there remained a great problem. Each regarded reality from a given point of view-that of the categories of Being. Each developed the ultimate consequence of that point of view: the Eleatic by a curt intellectual argument of incisive and summary completeness; the Vedântist by a vaster and more commanding process which touched the whole of life. Each came to the inevitable conclusion: reality is an indivisible and changeless One; the Many, an illusion. But that at once raises the question: "If reality is a changeless and indivisible One, how can it give rise to even an illusory appearance of a manifold ?"

And that question received no satisfactory answer from either school. Zeno, to whom the matter was a purely intellectual one, replies cheerfully enough: "Your experience of a manifold and of change must be an illusion; for, as I can show you, such an experience involves the most absurd contradictions." But that does not meet the case. Granted that my experience is an illusion, still how does even an illusory experience of change and of manifoldness come to be at all, when reality is a One, unchanging and indivisible?

1 See the hymn to Indra, translated by Max Müller, Origin and Growth of Religion (Hibbert Lectures), pp. 287-289; and the hymn to the Dawn in the second edition (London, 1868) of his Chips from a German Workshop, vol. I., pp. 36, 37. These may also be found in "The Hymns of the Rigveda translated with a popular commentary" by Ralph T. H. Griffith; the hymn to Indra (R-V. IV. 17) in vol. II. (Benares, 1890), pp. 118, 119; the hymn to the Dawn (R-V. VII. 77) in vol. III. (Benares, 1891), p. 97. 


\section{THE METAPHYSIC OF SPINOZA}

Nor can the Vedântist find any satisfactory way of escape. "Aham brahmâsmi," he says, "I am Bráhman." But if so, whence come the limitations under which the self in man labours? The answer is, that they are due to the Upâdhis-the obstructions. ${ }^{1}$ But whence come these? The answer is, once more, from Avidyâ, nescience. And Avidyâ comes to be conceived, not merely as personal ignorance, but a great independent cosmical power, which is able for a time to overshadow Bráhman itself. ${ }^{2}$ But how can Avidyâ thus 'affect Bráhman, who is all in all, "one without a second," subject to nothing outside it, because there is nothing outside it?3 The Vedântist can only answer that it is so. ${ }^{4}$ And when pressed as to how such a thing can be so, he can only fall back on the plan of Zeno; he can only attempt to involve his adversary in a selfcontradiction. It is self-contradictory, he urges, to seek to know what Avidyâ is. It is as though a man should endeavour to see darkness by means of a far-shining torch. ${ }^{5}$

Here, then, is the great theoretical or scientific difficulty of the metaphysic of the via negativa. The world of manifoldness and change refuses to be driven out of court. Whether as real or as illusory, it demands to be accounted for.

And this indicates to us what we must next do. We are attempting to see how this metaphysic has behaved in the field of the history of philosophy, in order that thereby we may get at its inner movement and genuine significance. We must, then, turn next to some instance where it felt the full weight of the problem just noticed, and put forth its whole power in the endeavour to solve it.

1 These are, as Deussen says (On the Philosophy of the Vedanta, Bombay, 1893, p. 12), "our whole psychological apparatus." Cf. the same author's System des Vedanta (Leipzig, 1883), S. 326 seq.

2 Max Müller, Three Lectures on the Vedânta Philosophy, p. 9i. Avidyâ in this sense came later to be called Mâyâ (ibid. p. 128).

3 Ibid. p. 97.

4 Ibid. p. 97.

5 Ibid. p. 99.-Cf. Deussen's “ . . . bleibet nichts übrig, als an die Negativität de Begriffes der Avidyâ zu erinnern."-Das System des Vedânta (Leipzig, 1883), S. 326. 


\section{THE METAPHYSIC OF SPINOZA}

$(\gamma)$

Such an instance we shall find by turning to one of those sad periods in our history, where the student, for the pity and the anger which gather at his heart, scarcely can keep his way. The great age of Greece was past. The work of the Greek race, as a race, had long been accomplished in East and in West. Rome herself was coming to the worst hours of her evil day. Life was a burden; a burden met by the few with the last wantonness of luxury, by the many with the dumb and hopeless patience which is the only refuge of the oppressed when the methods of revolutionary madness are not possible. The religious instinct was coming forward in its most negative form; namely, as a profound and passionate craving for deliverance from the evils and vicissitudes of life, from the perils and changes and agonies of the world. And along with this, science had entered upon a decrepid and decadent old age. Its instruments for carrying the manifold and the changing back into unity and eternity were as weak as the religious yearning for the One and the Eternal was strong. Under such circumstances it is no wonder that the metaphysic of the via negativa once more bècame dominant among men.

But with all this there went another fact. The manifold world could scarcely be dismissed as Zeno and the Vedântists had dismissed it. For the period now in question was the old age of a great civilisation. Many generations of labour, of culture, of splendid achievement, of orderly polity and developing institutions, had fixed and confirmed the hold of the world upon the minds of men. And so it is just here, in this troubled battle-ground upon the edge of darkness, where the religion and the science of the ancient world were going down to death together, clad in monstrous garments of the East-just here in the spiritual confusions which centred in Alexandria and in Syria but whose echoes were heard even in Rome and in Athens-that we shall find the negative philosophy in full struggle with its own great theoretical crux. This indeed is seen within the Christian Church as well as without it-in the Gnostics as well as in the Neo-Platonists. But it is with the latter, whose thought is seen at its greatest in the system of Plotinus, that we shall find the logic of the situation most conveniently shown. 


\section{THE METAPHYSIC OF SPINOZA}

On the one hand, Plotinus holds firmly to the negative or abstract view of the One. The One is unity without multiplicity, pure Being without change or becoming; nay, indeed, it is "beyond" even the category of Being. "It neither is," he says, "nor is it something, nor is it anything, but it is over all. All the categories are negatived; it has no magnitude, is not infinite."1

And yet, in the very next sentences, he goes on to say that the One is "the eternal source of virtue and the source of divine love, around which all moves, by which everything directs its course, in which voĩs and self-consciousness ever have their beginning and their end." In a word he allows a place for the manifold world; and views it as in some way having its source in the One.

Here, then, is the very situation which we wished to find-an instance in which the negative metaphysic, while holding to its view of the One, nevertheless finds a place for the world of manifoldness and change. Let us ask, then, by what means Plotinus accomplished this. What were his fundamental logical expedients?

They were mainly two. One was the theory of emanation. This, however, in spite of the great place which it took in the thinking of that age, is little more than a metaphor; and indeed only by metaphors ${ }^{2}$ was it made to convey any intelligible meaning.

But the other was one of the most ingenious logical devices ever hit upon by the contriving intellect of man. Plotinus sets up the idea of a sort of one-ended relation-or rather of a relation, all of whose motion is in one direction. As between the two terms of the relation, it is a relation when you go from the lower to the upper. But when you go from the upper to the lower, it is no relation at all.

1 Enn. VI. Bk. IX.-To deal systematically with Plotinus, one would have to ask first how he came to his view of the One as indeterminate. The answer would show us something new in the history of the negative tendency; new, however, not in character, but only in swiftness of movement. For Plotinus reached his view of the One, not by an unsparing dialectic argument working out the implications of a realistic beginning, but by concentrating such argument into the immediate affirmation of an intellectual intuition which apprehends the unity of experience and sets that unity, as the true reality over against the particular and finite. (See Erdmann, Hist. Philos. Eng. tr., vol. I., p. 239, and compare the excellent discussion in Caird's Evolution of Theology in the Greek Philosophers.) For our present purpose, however, it is not necessary to go into this.

${ }^{2} E . g .$, the snow emits cold ; and yet the snow remains itself, identical, undiminished. So, too, a luminous body with its light, or a flower with its fragrance. 


\section{THE METAPHYSIC OF SPINOZA}

To the lower term or member it is a relation, the lower being dependent upon the higher for its whole existence and meaning. But to the higher it is not a relation at all, in any sense which imposes metaphysical obligation or responsibility. "It is that," says Plotinus, of the One conceived as the Good, "on which all depends, and which all things desire and have as principle, and which they are all in want of, while it itself has lack of nothing, is sufficient for itself, and is the measure and limit of all; which out of itself gives the vor s, and essence, and soul, and life, and the activity of reason. . . . But it is itself by no means that of which it is the principle." 1

Thus, in Plotinus, the negative tendency wrestles with its own great theoretical shortcoming. A sort of reality is given to the manifold world. And at the same time the One remains nearly, though not quite, in accord with the negative conception of it. It has ceased, indeed, to be "all in all." But at any rate it remains a One which excludes all multiplicity, and is changeless and selfsufficient.

It is easy enough to point out the inadequacy of this solution. Metaphors, as such, are not metaphysic. And the idea of something which is a relation of $B$ to $A$, but not of $A$ to $B$, can only be called self-contradictory. With such criticism, however, we are not at this point concerned. Our business here is to learn what the negative tendency really is and really means; and to learn this by observing how it has behaved in the field of history.

The three great cases so far examined have shown us what the inner movement, and the genuine meaning, of this tendency are. With this we can pass on intelligently to Spinoza. But first we should turn for a moment to the period between Plotinus and the beginnings of specifically modern philosophy. For among the various appearances of the negative tendency in that period, there is one, the outline of which will give us a convenient summary of the chief points so far brought to light.

1 Enn. I. Bk. 8. 


\section{THE METAPHYSIC OF SPINOZA}

$(\delta)$

The whole mediæval period, indeed, is one vast illustration of this last and deepest of the distinctions that have arisen in thought and life as men seek to make themselves at one with ultimate and eternal reality. And that whether we regard the men of thought, or their methods of thinking, or the practical life which in part they shaped and which in part shaped them-a life half control of the world, half renunciation of the world. In the intense and passionate reasonings of Augustine which set the problems and laid the basis for mediæval thought; in the penetrating and radical insights of Erigena; in the massive thought of St. Thomas, where the doctrine of the simplicitas ${ }^{1}$ of the Divine nature crosses and thwarts the insight that all things, and all the determinations of things, have their being and their home in God ; $;^{2}$ in Nicolas of Cusa, whose view of the world may be taken as the last great expression of the mediæval spirit:-in all these the negative tendency is seen, one hardly knows whether to say in conflict or in combination with its opponents. These men all knew that the universal is the principle of reality; and that therefore the universal of universals is the ultimate object of all science and the true end of all conduct. Nor were they blind to the fact that that highest universal, that final unity of all things, must be a concrete and synthetic principle, the source and home and law of all the particulars of the world. But in attempting to reach that highest universal they were exposed_for reasons which we shall see later, ${ }^{3}$

1 This simplicitas is a oneness which excludes diversity. Diversity must be excluded from the Divine nature; for else the Divine nature would be a "compositum," and "omne compositum posterius est suis componentibus et dependens ex eis." Moreover "omne compositum causam habet." (See Summa Theol. I. 3. 7 ; and cf. I. 11. 1.-“unum non addit supra ens rem aliquam, sed tantum negationem divisionis"; cf. also Contra Gentiles, Bk. I. cap. 18.)

2 This may fairly be called the deepest insight in the philosophy of St. Thomas. It may be seen, for instance, by taking together the following doctrines and considering the consequences of their synthesis.-(1) God has "propriam cognitionem de omnibus rebus." (Contra Gentiles, I. 50.-cf. 67-71-and cf. also the parallel passages in the Summa Theol. e.g., I. 14. 9-13.) (2) Scientia Dei est causa rerum. (Summa Theol. I. 14. 8.) (3) But "intelligere" is "the activity or energising (actus) of an intelligence which exists in itself and does not pass over into anything extrinsic to it, as, for instance, heating passes over into that which is heated." (Contra Gentiles, I. 45. 1.)-I have attempted at a later page to work this out more fully (infra, pp. 336-341).

3 Infra, pp. 218, 219. 


\section{THE METAPHYSIC OF SPINOZA}

were specially exposed-to the temptation which always waits upon that endeavour: the temptation to have recourse to the simple and easy expedient of stripping away from the given particulars their differentiating peculiarities and retaining only the common element. Such a process, as it ascends through the stages of widening universality, strips away all determinations, and leaves us at the end with an altogether abstract and empty Absolute. In the presence of such an Absolute, if you are possessed by the instinct and passion of religion, there is but one type of religion still open to you-the mystical. And if you have felt keenly the imperfection and the sorrows of the world, you may refuse to grieve that your logic calls you and your fellows to such a goal; indeed, in bringing you to that goal, your sense of the eril of the world has probably been more influential than your logic.

But over those great names we must pass. To two of them we shall return later, but here we must confine ourselves to a single mediæval instance; one, howerer, which in interest and attraction yields not eren to those. In the thinking of those "dear friends of God," the medirval Mystics, the philosophy of the via negativa assumes the most winning form which it has erer had in the history of man. In its logical morement it remains true to type. It shows that keen dialectical development from realistic grounds and methods, which has characterised so many of its great historical appearances. But to this it added a grace that has won the reluctant hearts of later and more earthly generations. And the height of its moral passion made it a power effective for the regeneration of the religious life of the day-a religious life externalised, hardened, tending, by that tragedy which waits upon priestly churches, to lose itself in the rast forms of the very structure which it had been building up through long centuries to be its home.

So complete, indeed, is the evolution of the negative philosophy in the hands of the Mystics within the mediæral church, that we shall find united in their thinking nearly all those main features and characters which so far we have discovered by studying widely diverse cases. A rapid enumeration of the main points in their teaching 


\section{THE METAPHYSIC OF SPINOZA}

will thus afford us that brief summing up of the whole position which we wish to make before passing on to Spinoza.

(1) As they make their way from the particulars given in experience to a vision of the highest universal, they do not take the particulars along with them so that when the universal is gained the particulars are seen transformed in its light and displayed as genuine elements of the eternal. Rather they gain their One as did Parmenides and the Vedântists, by being fully in earnest with the category, or point of view, of Pure Being, and by rigorously carrying that point of view to its last conclusions. Eckhart was a master of the Scholastic learning; what he did, as a man of thought, was to give complete right of way to tendencies and methods already present in Scholastic Realism, ${ }^{1}$ until at last he passes beyond the distinction between the God who knows and the begotten or created world which $\mathrm{He}$ knows to that ultimate and purely unitary Godhead in which there is neither knowledge nor action (" never did it look upon deed"), neither Father nor Son nor Holy Ghost. Windelband has pointed out that what held the great Schoolmen back from working out this development themselves, was the high value which Augustine had taught them to set upon personality. ${ }^{2}$ But with teachers who were led, by just their keen feeling for personality and for the sorrows and evils which it brings, to wish for its suppression rather than for its encouragement, this check was taken away, and the realistic logic, hastening forward to its conclusion, came to the goal where all logic is hushed. The ultimate reality has no determination or quality; is, in Philo's word, $\ddot{\alpha} \pi 0 z 05$. Not merely is it above reason; but even Being, the emptiest of all categories, is regarded as too particularised a conception for it, and it is declared to be beyond Being. It is not "Icht" but "Nicht." " . . . Therefore," says the author of the Theologia Germanica, "we do not give a name to the Perfect, for it is none of these. The creature as creature cannot know nor apprehend it, name or conceive it. . . . In what measure we put off the creature, in the same measure are we able to put on the Creator; neither more nor less."3

1 Cf. 145, 146, supra; and 218, 219, infra.

2 Hist. Philos. tr. Tufts (1893), p. 340.

3 Theologia Germanica, tr. Miss Winkworth, chap. I. 
And again " . . . He who findeth satisfaction in aught which is this and that, findeth it not in God; and he who findeth it in God, findeth it in nothing else, but in that which is neither this nor that, but is All. For God is One, and must be One, and God is All and must be All. And now what is, and is not One, is not God; and what is and is not All and above All, is also not God, for God is One and above One, and All and above All. Now he who findeth full satisfaction in God, receiveth all his satisfaction from One source, and from One only, as One. And a man cannot find all satisfaction in God, unless all things are One to him, and One is All, and something [some particular thing] and nothing (icht und nicht) are alike."1

(2) But no sooner has this point been reached than they are face to face with their great problem-the problem set by the manifold and determinate world, whose divine and angelic orders are declared by theology, and whose earthly facts are given in experience. This they see clearly, and set themselves to the task of deriving the universe of particular existences from that ultimate which cannot even be described as Being, which can as well be called non-Being as Being. In that still and formless quiet, a morement of selfapprehension and self-utterance is declared to take place. Thus arises a double outflowing. First, there is an outflowing of that which is God, and in this the Godhead of the Christian religion comes to be. Secondly, there is an outflowing of that which is not God (and therefore is mere nothing); by this all the world of creatures arises. ${ }^{2}$ Into the details of this account we are, however, not obliged to go. ${ }^{3}$ What concerns us is the fact that the situation itself was understood, and was deliberately faced. It should be noted, however, that the very first step in the solution-the postulated self-apprehension and self-

1 Theologia Germanica, tr. Miss Wink worth, chap. XLVI.-Of course, in the Theologia Germanica, an intensely practical book written in the Western Church, one must not look for the negative view in an uncontradicted form. The same is to be said of the $D e$ Imitatione Christi.

2 If we overlap three centuries, and the sundering gulf of the Reformation, we find the same attempt on a still more Titanic scale in the vast imaginations of Böhme's cosmogony and cosmology. But one must note how, in Böhme's hostility to the doctrine of a creation out of nothing, there comes forward the desire for a positive or concrete doctrine of creation-i.e., a doctrine that will show an organic relation between the creature and the very nature of God.

3 References to Pfeiffer are given by Erdmann, Hist. Philos. Eng. tr. vol. I., p. 549. 


\section{THE METAPHYSIC OF SPINOZA}

utterance-contradicts the original account of the ultimate reality. It is a salto mortale; the gulf is impassable, but it is to be taken as crossed.

(3) And this account of the origin of the world of creatures involves a view of the self in man similar to that worked out by the Vedântists. For the account given of that outflowing from God by which the creature comes to be, implies that what makes the creature a creature-what distinguishes him, or it, from God-is really nothing at all. If we could strip away these nothingnesses and get at the genuine reality of the creature-what Eckhart called the "Spark," the point or apex of the soul which is divine and makes salvation possible - that reality would be nothing other than the one eternal reality of God. " "Thou sayest,", the author of the Theologia Germanica imagines the objector to say, " "beside the Perfect there is no substance, yet sayest again, that somewhat floweth out from it: now is not that which hath flowed out from it something beside it?' Answer: This is why we say, beside it, or without it [outside of it] there is no true Substance. That which hath flowed forth from it, is no true Substance and hath no Substance except in the Perfect, but is an accident, or a brightness or a visible appearance, which is no Substance, and hath no Substance except in the fire whence the brightness flowed forth, such as the sun or a candle."1

(4) Finally, all this is carried forward to its ethical and religious application. These nothingnesses which separate us, as creatures, from God-these qualities and determinations, this being "here" and "now," which make us to be creatures, and hide from us our home in God-let us strip them away. "Thou shalt sink thy thine-ness and thy thine shall become a mine in his mine," says Eckhart to the soul ${ }^{2}$ in describing the process of its salvation; a process summed up in that virtue of Abgeschiedenheit, in which by heroic struggle the moveless inner divine man subdues to himself the

1 Miss Winkworth's translation, chap. I.-Note the Neo-Platonic idea of emanation in the last sentence, contained, characteristically, in a metaphor. - Note too that what to the Vedantist was an express view of the self, is here only the implication regarding the self, of the general doctrine as to the creature. (Cf. Erdmann, Hist. Philos. Eng. tr. vol. I., pp. 549, 550.)

2 See Erdmann, Hist. Philos. Eng. tr. vol. I., p. 552. Cf. the reference (p. 219 infra) to Professor Royce's paper on Eckhart. 


\section{THE METAPHYSIC OF SPINOZA}

outer man who is a creature of desire and change; though the intense and practical character of Eckhart's religious endeavours made it difficult enough for him to remain consistently at this point of view. The same teaching, though again with the same qualification, is found in the Theologia Germanica. "Now mark: when the creature claimeth for its own anything good, such as Substance, Life, Knowledge, Power, and in short whatever we should call good, as if it were that, or possessed that, or that were itself, or that proceeded from it-as often as this cometh to pass, the creature goeth astray. What did the devil do else, or what was his going astray and his fall else, but that he claimed for himself to be also somewhat, and would have it that somewhat was his, and somewhat was due to him? This setting up of a claim, and his I and Me and Mine, these were his going astray, and his fall. And thus it is to this day." "Behold on this sort must we cast all things from us, and strip ourselves of them; we must refrain from claiming anything for our own." "For if the left eye be fulfilling its office toward outward things; that is, holding converse with time and the creatures; then must the right eye be hindered in the working" [i.e., "seeing into eternity"].. "Let no one suppose, that we may attain to this true light and perfect knowledge, or life of Christ, by much questioning, or by hearsay, or by reading and study, nor yet by high skill and great learning. Yea, so long as a man taketh account of anything which is this or that, whether it be himself, or any other creature; or doeth anything, or frameth a purpose, for the sake of his own likings, or desires, or opinions, or ends, he cometh not unto the life of Christ."4 "Be assured, he who helpeth a man to his own will, helpeth him to the worst that he can." And with this may be compared the great lesson De contemptu omnium vantitatum mundi which à Kempis is never weary of inculcating, and the lesson that we must withhold our minds from all the creatures in order that we may find the Creator; for that which is not God is nothing, and is to be accounted as nothing.

\footnotetext{
1 Miss Winkworth's translation, chap. II.

3 Ibid. chap. VII.

4 Ibid. chap. XIX.
}

2 Ibid. chap. V.

5 Ibid. chap. XXXIV. 


\section{THE METAPHYSIC OF SPINOZA}

V.

Such was the attempt, in the thought and in the life of the older world, to rise by the negative way from appearances to reality. The four cases which we have examined show the inner logic of that endeavour; show the essential contradiction which vexes it; and show something more-to what practical efficiency in evil days, and to what clear shining of heavenly light in the soul, it was possible for men to rise by that bleak and apparently hopeless road of denial.

When we leave those ages behind us and come to our own, it seems as if the last possibility of mystic thought or life had departed. The air is different. For good and for evil, the world has made us its own. And yet Mysticism, alike in its logic and in its life, has had its place among us; and in both aspects has been surprisingly true to its ancient type. As a practical spirit it has passed, as of old, "like night from land to land," in unexpected places finding out its own, leaving, to mark its course, here and there a starry name but usually only the atmosphere of its peace. In the Church of England, in Germany-though not now as once-and specially among the Friends, it has laid its finger upon its chosen, and in them has given to the modern world well-nigh its most admirable type of character. And once at least it moved with terrific energies; many an Englishman, in the civil war, struck hard with the sword, and showed no mercy in victory, nor lost hope in defeat, because he had in him as an inner fire the same instinct that in earlier days led men to the silent life-the instinct for the immediate ascent of the soul to God.

On the speculative side, the history is easier to trace; for there the mystic conception of ultimate reality came forward in the place determined by that secular logic which leads philosophy through its epochs. Hence the mystic view of reality, as it appeared in modern thought, was at once new and old: old, in that it unconsciously repeated an ancient situation and an ancient movement of thoughtfor Mysticism is really the one theology of which men ought to say "semper eadem"; new, in that it is original and independent, arising from its own modern sources and moving by its own impulses. It was a stage - a stage integral, essential, necessary-in the working 


\section{THE METAPHYSIC OF SPINOZA}

out of a scientific process which began with the beginning of the modern world. In Greece the first men of science had, as we have already seen, to begin at the very beginning. And in the long-drawn carrying out of the attempt which they initiated, the thought of Parmenides not merely occupies a place; it occupies a place logically inevitable, performs a function logically necessary. In modern thought there has been something very similar. Those who stood at the beginning of the modern period held it necessary that science and philosophy should do their work all over again; should go back to the very beginning and make their start once more from that point; should, from the very bottom, build themselves up altogether anew. And the long working out of the endeavour thus initiated proceeded, as among ancient Greeks, so among modern Europeans, with strict logical continuity. In the latter case, as in the former, there came a point where the negative view showed itself as a necessary and inevitable stage in the logical evolution. And at that point stood Spinoza.

But the life of the first era of modern Europe was a much more complex thing than that of the age in which Greek science began to be. This is reflected in the way in which the negative metaphysic takes its rise in Spinoza's thought; and is reflected in another thing which we shall have to study a little later-the way, namely, in which, in Spinoza's thinking, it has to share its throne with its great opponents, as with Eleatics and Vedântists it had not to do.

For, as we study its genesis in Spinoza, the first factor that we find is a moral and religious one. Experience, as he tells us in the remarkable opening pages of his treatise on Method, ${ }_{1}^{1}$ had taught him that "all the usual surroundings of social life are vain and futile." Further reflection convinced him that if he "could really get to the root of the matter" he "would be leaving certain evils for a certain good." He "thus perceived that he was in a state of great peril" and he "compelled himself to seek with all" his "strength for a remedy however uncertain it might be; as a sick man struggling with

1 Tractatus de Intellectus Emendatione. I have followed Elwes' translation (2nd ed. revised) of Spinoza's "Chief Works," save where references to some other edition or translation are given. 


\section{THE METAPHYSIC OF SPINOZA}

a deadly disease, when he sees that death will surely be upon him unless a remedy be found, is compelled to seek such a remedy with all his strength, inasmuch as his whole hope lies therein." He was able to see, however, what the source of all these evils is, and so in what direction the way of escape from them must lie, if any such way of escape there be. "All these evils," he says, "seem to have arisen from the fact that happiness or unhappiness is made wholly to depend on the quality of the object which we love. When a thing is not loved, no quarrels will arise concerning it-no sadness will be felt if it perishes -no envy if it is possessed by another-no fear, no hatred, no disturbances of the mind. All these arise from the love of what is perishable, such as the objects already mentioned [riches, fame, pleasures of sense]. But love toward a thing eternal and infinite feeds the mind wholly with joy, and is itself unmingled with any sadness, wherefore it is greatly to be desired and sought for with all our strength."

With Spinoza then, as with Vedântist and Neo-Platonist and mediæval Mystic, it is primarily a moral or religious passion which sets him at work. It is a passion after that Eternal, by making our home in which we shall be delivered from the vanities and the evils of this life. But if we are to understand that fact aright, we must give careful heed to three other facts. First, when a man undertakes a scientific task, he has to work with scientific instruments no matter whether the interest that set him at the work was primarily a moral and religious, or primarily an intellectual, one; and therefore the work itself must in the first instance be studied and be judged as science. Secondly, Spinoza's was a mind of such an order, that his religious interest made him work all the more truly in the scientific spirit. Just because the stake was so great, therefore the science must be as accurate as possible. Just because it was a matter of life and death in the deepest sense of those words, therefore logic must have its uttermost right and do its uttermost work. But, thirdly, even more than that is true. Spinoza's nature was as truly scientific as it was truly religious. He was animated by the scientific passion as truly as by the religious. He had the instinct for rationalising the world, as truly as the longing after an eternal object for his love. 


\section{THE METAPHYSIC OF SPINOZA}

All these three counts require us to consider his system as a piece of rational science-as a logical structure. And in doing that, our first endeavour must be, with him as with Parmenides or Eckhart, to understand the logical situation in which he found himself and which gave him his point of departure. What that situation was we may see by considering carefully just what Descartes had done in his attempt to begin at the very beginning and to build up thence a science which should be trustworthy because from beginning to end no untested material had been admitted.

Descartes, then, after stripping away all traditions, all doctrines, all principles, which lie in any way open to doubt, still finds one thing which emphatically is. It so truly is, that even in attempting to doubt its existence, one asserts its existence. Cogito, ergo sum. I, the thinker, am. Or, as we should probably say nowadays: "Thought is."

So far, good. But the really important question is: What did Descartes do with the cogito when he had got it? This may best be seen by comparing what Descartes did with what a later philosophy did. This later philosophy perceived that in the cogito-in all thought, though it be the kind of thought called doubt, or even though it be the kind involved in sense-perception-there is involved, on the one hand, a subjective consciousness, and on the other, an objective consciousness in which certain principles are operative. But this consciousness of objects and that consciousness of self are seen to be correlative, neither being possible apart from the other; so that they constitute together a consciousness which is truly one and not two. This consciousness, then, this cogito, in which many facts and operations are thus present in one self-conscious grasp, is a true and veritable Many-in-One; in it is found a genuine principle of unity-in-diversity. And with this, the problem of the Many and the One at which science and philosophy have been labouring from the beginning, comes at last to its solution -in the conception of a supreme self-consciousness, or spirit, who is the subject of the world.

Now there is, it is true, something in Descartes' treatment of the cogito which looks straight in this direction. And that something a modern student, trained in the school of Platonic or Hegelian Ideal- 


\section{THE METAPHYSIC OF SPINOZA}

ism, would at once seize upon as the deepest and most valuable insight of the Cartesian philosophy. It lies in the fact that to Descartes our highest category is the conception of God. In all our judging-when we doubt or criticise, when we find things to be imperfect or finitethere is involved an explicit or implicit conception of a being perfect and infinite; only through the conception of the perfect and infinite can we judge anything to be finite or imperfect. In other words, our consciousness of God is the impelling element in all our knowledge. It is, so to speak, the vital soul of the cogito. Without it there could be no such thing as knowledge or thinking at all. $r$

But to this insight that an explicit or implicit consciousness of God constitutes the very essence of the cogito, and is the basis of all knowledge, neither Descartes nor his age could do justice. Nor was it to be expected that they should. There is no royal road to metaphysic as reasoned science. If men are to use a higher category as an assured instrument of orderly and abiding scientific insight, they must first work their way through the stubborn dialectic of the lower categories. So it was in Greek philosophy; and the case was not otherwise with the philosophy of modern Europe. So that what we must deal with here is not that idealistic Descartes whom a Platonist or a Kantian may very rightly dig up out of the Meditations; it is the Descartes whom that age received; and in particular it is the Descartes who furnished to Spinoza his point of departure. We must inquire very carefully what that Descartes did with the indubitable reality which he had found even in the midst of doubt-with that vital union of subject and object which he summed up in the word cogito.

And first we must notice that in his attempt to found science and philosophy anew, he began at the beginning in a far more rudimentary sense than he himself imagined. In dealing with the cogito, the Descartes that we are here concerned with drew his point of view and his principles of explanation from the first and lowest of the families of the categories. He went to the categories of Being and employed in particular the category of Substance; adopted, that is to say, the method of explanation in which the pure, eternal, unchangeable, uncompounded Being is, in some way, put under or 


\section{THE METAPHYSIC OF SPINOZA}

behind the visible and changing qualities with which in our experience we have directly to deal, and is viewed as the substrate of those qualities. The result of this was that he ended by splitting the cogito into two. That is, he sharply sundered the subjective consciousness and the consciousness of objects. Each he treated by itself; but of course, since they were viewed as co-ordinate realities, used the same category and followed the same schema in each case. In dealing with the subjective consciousness, he conceived the ego, which is the subject of the cogito, as a substance-a "thinking thing"-and "thought" was its attribute. Of this attribute. the various states of mind (ideas, feelings, volitions, and so on) are modifications. What leads him to this, is just the perception that these latter, these "states of consciousness" which he comes in the end to call modifications, cannot stand alone. They are not selfintelligible. Per aliud, non per se, concipiuntur. And so we are referred back, and back, and back, until we come to something which fulfils the great requirement; something quod per se concipitur. This is thought. But even yet Descartes is not quite satisfied. Thought can be conceived through itself, it is true. But yet, there is an ego which is the subject of the cogito; an ego whose essence and nature it is to be a thinking thing. And so we get the complete scheme:- - the substance or thinking thing; its attribute, thought; and the descending orders of the modifications of this attributemodes, and modes of modes, and modes of these again as far as you choose to go. Thus, then, Descartes dealt with the subjective consciousness. But, next, he finds a great order of facts or qualities which he does not feel able to assign to the subjective consciousness, and these he simply casts out of the cogito altogether. ${ }^{1}$ Here also the same line of reflexion is followed out; the same search made after something which can stand alone and be conceived through itself. And this gives us the same general form on this side as on the other:-a substance (body), its attribute (extension), and the various modifications of this attribute.

Furthermore, these two spheres are quite independent of each other. Each of these two substances can exist, and be conceived, 


\section{THE METAPHYSIC OF SPINOZA}

without the help of the other. Indeed it is of the nature of substances to be mutually exclusive. ${ }^{1}$ And the attributes are as radically opposed to each other, are as mutually exclusive, as the substances. Extension is not conscious; thought is not extended. In a word, whatever thought is, that extension is not; and whatever extension is, that thought is not. If anything falls within one, it falls without the other.

But this absolute disjunction plunges us at once into difficulties. For in our actual experience these two orders of being most certainly come into connexion with each other. I, the thinking thing, have an experience of extended things. We have, then, a double problem on our hands. First, an empirical problem: By what expedient is that connexion as a matter of fact brought about? And secondly, a metaphysical problem: How, ultimately, is the possibility itself of that connexion to be accounted for? Descartes' answer to the former, seen in his theory of the passions and in his view of the function of the pineal gland, need not concern us here. But his answer to the latter is of radical importance.

What he did not do, in this answer, was to remove the difficulty itself by recognising the organic connexion of thought and the extended world. Gassendi in his Objections forced Descartes to the point where to a student of to-day this recognition seems unavoidable. But it was beyond the power of the philosophy of that age to make the recognition in any vital way. A few sentences from the argument between Gassendi and Descartes will show how the matter stood. " . . . parceque d'un côté," Descartes had said in the sixth Meditation, " "j'ai une claire et distincte idée de moi-même, en tant que je suis seulement une chose qui pense, et non étendue, et

1 One finds such statements as, for instance, the following-"Sed jam dicendum est quo pacto ex hoc solo quod unam substantiam absque altera clarè \& distincte intelligam, certus sim unam ab alia excludi. Nempe haec ipsa est notio substantiae, quod per se, hoc est absque ope ullius alterius substantiae possit existere, nec ullus unquam qui duas substantias per duos diversos conceptus percepit, non judicavit illas esse realiter dis tinctas." (Responsiones quartae, p. 124-Second Elzevir edition.)-Indeed from the point of view of "Being" substances must be mutually exclusive. This Parmenides saw clearly ; and then, with his principle that in the real there is no "is not," leapt at once to the conclusion that the real is one indivisible substance.

2 Cousin's edition (Paris : Levrault, 1824-26), tome I., p. 332 . In the Elzevir edition, the fifth and seventh "Objections and Replies" (the fifth being the discussion with Gassendi) are given as an Appendix. 


\section{THE METAPHYSIC OF SPINOZA}

que d'un autre j'ai une idée distincte du corps, en tant qu'il est seulement une chose étendue et qui ne pense point, il est certain que moi, c'est-à-dire mon âme par laquelle je suis ce que je suis, est entièrement et véritablement distincte de mon corps, et qu'elle peut être ou exister sans lui." Gassendi, in the course of his argument, raises this point. " “. . . mais supposé, comme vous dites, que vous soyez une chose qui n'est point étendue, je nie absolument que vous en puissiez avoir l'idée. Car, je vous prie, dites-nous comment vous pensez que l'espèce ou l'idée du corps qui est étendu puisse être reçue en vous, c'est-à-dire en une substance qui n'est point étendue ?'”2 Descartes' answer is rather a clever parrying of the difficulty than a solution of it.-“ “Je réponds à cela qu'aucune espèce corporelle n'est reçue dans l'esprit, mais que la conception ou l'intellection pure des choses, soit corporelles, soit spirituelles, se fait sans aucune image ou espèce corporelle."3 So that to the end Descartes held to the mutual independence, the mutual exclusiveness, of thought and extension.

And what he did do, in endeavouring to meet the difficulty, was this. He made the two substances, of which extension and thought are the respective attributes, subordinate, and premised, to effect their connexion with each other, a third substance which is God. "By substance," he says, "we can conceive nothing else than a thing which exists in such a way as to stand in need of nothing beyond itself in order to its existence. And, in truth, there ean be conceived but one substance which is absolutely independent, and that is God. . . Created substances, however, whether corporeal or thinking, may be conceived under this common concept [of substance] for these are things which in order to their existence, stand in need of nothing but the concourse of God."4 Thinking substance and extended substance, then, are not independent of God. But their independence of each other Descartes maintains stoutly and to the end.

It was this thinking, then, and the logical situation which arose 1 With regard, as he points out, not to "corps on general," but to "corps massif et grossier.

2 Ed. cited, tome II., p. 224.

3 Ed. cited, tome II., p. 297.

4 Principles, I. 51, 52, tr. Veitch (Blackwood). 


\section{THE METAPHYSIC OF SPINOZA}

out of this thinking, that furnished to Spinoza his scientific point of departure. True, Spinoza brought with him elements which orthodox Cartesians would have repudiated with becoming severityelements from ben Maimon; from Chasdai Creskas; especially from Ibn, Ezra, and through him from that heretical Jew pantheist, Avicebron; possibly even from Bruno. True also, he brought to the Cartesian philosophy, deep spiritual passions of a kind to which it was a stranger. And true, moreover, he often states in strangely sharp and pointed language his opposition to this or that tenet of Descartes. ${ }^{1}$ But the fact remains that the logical situation created by Cartesianism was Spinoza's scientific point of departure; and that by Spinoza's work the fundamental lines in the movement of Cartesian thought were carried forward to their logical conclusion. That he himself had no special intention to do this; that he did not regard his own system as standing in any very intimate connexion with the Cartesian system:- these things do not settle the question. And to urge either his occasional sharp criticisms of Descartes, or the bitter repudiation of him by the orthodox Cartesian schools, as a reason for refusing to regard him as the man of thought who revealed the ultimate meaning of the Cartesian categories and the Cartesian method, is to miss the genuine core of the situation because of some of its external incidents:-is to miss the main set of the tide because of one or two of its prominent and rather noisy eddies. Spinoza lived, whether he would or no, in the Cartesian current. In his long and quiet meditations, the Cartesia thought ripened and worked itself out. And the outcome was that he became to the first stage of modern philosophy what Parmenides had been to the first stage of Greek philosophy-the man who made clear the goal toward which its method led, and the view of the world which lay implicit in its working principle.

The position into which Spinoza was thus brought is what we have now to consider. The advance which he made upon the Cartesian position may be briefly outlined as follows :

In the first place he saw that there was really no need at all for Descartes to set up his hopeless problem of the connexion of two

1 E.g., Eth. beginning of Pt. III. and especially beginning of Pt. V. 


\section{THE METAPHYSIC OF SPINOZA}

substances which are independent of each other. For what Descartes had on the one side was really nothing more than an attribute and its modifications. And what he had on the other side was likewise really nothing more than an attribute and its modifications. There was no need at all to put a distinct substance behind each of these attributes. Indeed to do so was to misuse the category of substance itself. For a substance is precisely that which is needed as the support or the home of a variety of attributes; it is the single substrate required to bring the many attributes back into unity of existence. What Descartes should have said, then, was very simple: there is one substance, and in that one substance both these attributes inhere.

So that Spinoza's assertion that substance is One, simply completes the evolution of Descartes' thought. To Descartes substance is that "which so exists as to stand in need of nothing beyond itself in order to its existence." But upon that definition-unless we assert the existence of a plurality of absolutely independent universes or monads - there can be but one substance. And this, as was noted above, Descartes himself saw. There can be conceived, he admitted, but one substance which is absolutely independent [i.e., which really does fulfil the definition], and that is God. We perceive that all other things can exist only through the concourse of God [i.e., according to the definition are not substances at all]. But he avoided the force of this, and avoided the transformation of his system which it required, by adding that the term substance does not apply to God and the creatures univoce; "that is, no signification of this word can be distinctly understood which is common to God and them."1 Descartes, that is to say, at once retains and does not retain the scheme of the world which he had worked out by the use of the category of substance. But the excommunicated Jew with his piercing intelligence could not remain, as the loyal (and, let me insist, sincere) son of the church remained, in such a position. That which Descartes admitted, Spinoza insisted upon, and put in its proper place in the system. For him, from the beginning, reality is One Substance. And this is the first great step, the first main position, in Spinoza's metaphysic. 


\section{THE METAPHYSIC OF SPINOZA}

This first step consisted, it will be seen, in a strịcter use of the fundamental Cartesian category, not in an advance from it to a higher category. In other words, Spinoza did not correct Descartes by insisting upon a more accurate treatment of the cogito. He did not point out that the objective consciousness-that of which the consciousness of extended objects is one aspect-is correlative to the subjective consciousness. He did not point out, to put the same thing in another way, that extension is relative to thought, exists for thought, and so comes within the sphere of thought. Such a correction as that, it was left for Kant to make. What Spinoza did was to take his stand upon the Cartesian category and insist upon a more thoroughgoing application of it. And this fact is of the very highest importance for Spinoza's whole system. For it not only gave the first step in it; but it also, as we have now to see, determined the second step. And this second step was, if possible, more important than the first; leads directly, indeed, to the negative conclusion; or rather, is the negative conclusion.

What that second step was, an illustration will help to make plain. I assert, let us say, that self-consciousness is the highest principle of science-that reality consists in a single self-conscious and selfdetermining spirit, and in its activities which are the world and the history of the world. Thereupon an objector challenges me. "Selfconsciousness the highest principle of science? But exactly what does that tell me? What do I know of the nature of self-consciousness?" But to this I can at once make an answer: Tat tvam asi-thou art it. Now it is just this question which Spinoza had to face as soon as he had taken that first step which we have just seen. Reality is One Substance. Be it so; but what does that tell us? What can we know about the nature of the One Substance?

And the key to this situation lay in the fact already indicated; the fact, namely, that the category of substance itself, by which Spinoza had shown himself so determined to abide, involves an answer to this question. This Parmenides had seen, and had worked out with clear and unflinching logic. This also Spinoza saw and worked out; and, by doing so, gained the great regulative principle of his philosophy. 


\section{THE METAPHYSIC OF SPINOZA}

This point we must consider very carefully. We shall best comprehend Spinoza's procedure here by comparing it with that of the earlier historical instances which we have studied. We have seen that the thinking which moves on the level of the categories of Being has to make an absolute disjunction of " is" and " is not." The "is" is a pure "is," and there is no place for any "is not" in it. But from this two things at once follow. First, the true and veritable Being is apart from all change; for no "is not" can ever creep in to bring about any alteration. Secondly, that true and veritable Being must be apart from all limitations or determinations; for these also involve an element of "is not." This Parmenides saw and his whole system was simply the formulation of this single insight. This, too, the mediæval Mystics saw; as is specially evident in their doctrine of the creature. That procession from God by which the creature comes to be, is, they said, a procession of that which is not God, i.e., is a procession of non-Being. Which is just to say that Being belongs to God alone, and that the determinations which make the creature seem to be an individual distinct from God, are really nothing at all. ${ }^{1}$

It is this very same line of thought which Spinoza at this point follows out. First of all he sees that determination involves an element of "is not." But this insight has at least two possible meanings. To a man who stands at a certain logical level, it has one significance. To a man who stands at a certain other logical level, it has an altogether different significance. It will be advisable, in order to understand exactly what it meant for Spinoza, to set these two meanings side by side.

The first is expressed more exactly by saying that affirmation involves negation. Affirmation and negation are correlative. Each, for its own existence, requires the other. If you characterize anything as "this" you distinguish it from "that." But-and this is the key to the whole matter-it is just because a thing can be such a "this" that it can have a place and a function in the system of the universe at all. So that there is a sense in which determination is negation. But this insight receives all its meaning from the still

1 A conclusion to which, as we have seen, the Vedântists also come; and by an argument that differs more in mode of expression than in logical content. 


\section{THE METAPHYSIC OF SPINOZA}

deeper insight which goes along with it. For the universe is seen to be a determinate system-a system articulated in inner determinations; and the kind of negation involved in determination is seen to be necessary to the existence of a universe at all.

But that is not what the principle meant to Spinoza. His thought moves in the region of the Being-categories. And there the "is not," so far from being considered necessary to reality, has to be cast out of reality altogether. A spatial illustration may make this somewhat more clear. Imagine a cubic foot of space in some definite position-say, at your right hand. Now, what is it that prevents you, considered as the possessor of that defined portion of space, from having the whole of space? It is the determinations-the limitations which give to that piece or fragment of space its size and shape. If these particular limitations, and all limitations of this kind, were annihilated, you would have the whole of space. If we carry through . an argument of this sort, not with regard to space merely, but with regard to reality as a whole, we get Spinoza's own conception of the meaning of his great principle. This or that particular thing-so he felt-is a piece or fragment of reality. But if all the limitations, all the determinations, which make it "this" or "that," were swept away, then you would have not a piece or fragment of reality, but reality itself. A particular thing is the One Substance with the greater part-in most cases, indeed, with nearly all—of its reality negated by determinations. ${ }^{1}$ Such, then, was to Spinoza the principle, Omnis determinatio est negatio. And such a principle, so construed, leads him at once to the principle that the One Substance is indeterminate. ${ }^{2}$ Every determination is viewed as a negation of reality. Therefore the One Reality is beyond all determinations.

1 See, for instance, his explanation in a letter to Jarig Jellis (Ep.L.), of the doctrine that figure is negation. "This determination [figure] therefore does not appertain to the thing according to its being, but on the contrary is its non-being." (Elwes, vol. II., pp. 369, 370.) So that the application of the term modus to particular things is literally consistent. A particular thing is a mode or manner in which the One Substance exists. And it is precisely the determinations which bring it about that, in the particular thing, the One Reality exists, not in its wholeness, but only in this very partial mode or manner. The full carrying out of this would have given the Mystics' doctrine of the creature, or the Vedântists' doctrine of the human self.

2 See, for example, the second letter to Huyghens (Ep. XXXVI.)-"Now since the nature of God is not confined to a certain sphere of being, but exists in being, which is absolutely indeterminate, so His nature also demands everything which perfectly expresses being ; otherwise His nature would be determinate and deficient."-(Elwes, vol. II., p. 357-italics mine.) 


\section{THE METAPHYSIC OF SPINOZA}

So far, then, Spinoza has done exactly what Vedântist and Eleatic and Mystic did. He has worked, as they did, with a category which belongs to the general family of the Being-Categories. He has taken, as they did, three great steps which represent the strictest and most faithful working out of the logic of that category. First, he has conceived reality as a One-a One whose unity excludes all dividedness or multiplicity. Secondly, he has affirmed that all determinations are negations of reality. Thirdly, he has declared the One to be therefore indeterminate.

These principles can serve, and, as we already know, several times have served, as the ground-lines of a system of philosophy. They are not merely consistent with one another, but are a rigidly consistent development of the inner meaning of that category which furnishes the original point of departure. They need only to be more minutely explicated, and to be applied to the problems of practice, in order to give such a full-orbed and thoroughgoing system as is found in the Vedânta or in the school of Eckhart. In dealing with Spinoza, then, let us set these three great positions together, as representing a single factor or movement in his thought. And this movement in, or aspect of, his thinking, let us call his "first metaphysic."

But now, will Spinoza give to these principles just that development and application which would round them out into such a system as we have seen in Vedântist and Mystic? Our study of those earlier systems has shown us what direction such development and application would have to take. There remain yet a fourth and a fifth step. The fourth step would proceed as follows.-All determinations are negations of reality. Therefore the separateness from the One which the particular things and beings of the world appear to have by reason of their determinations, is, after all, an illusory separateness. The One alone $i$, and what distinguishes us from it is really nothing at all. ${ }^{1}$ This, when fully articulated, would give us a doctrine like the Vedântist doctrine of the self, or the Mystic doctrine of the creature. Then the fifth step would advance to the ethical and religious application of all this-similar, for instance, to what we

1 Indeed, with regard to one order of determinations, Spinoza did virtually affirm this. In the letter to Jarig Jellis referred to above (p. 163, note) he called the determination of figure " the non-being of the thing." 


\section{THE METAPHYSIC OF SPINOZA}

have already seen in the teaching of Eckhart or in the more consistent teaching of the "Forest Schools." With this, the system as a system would be fully rounded out. The only thing that would still remain to be constructed would be its Apologetic-its defence of itself against that great theoretical objection which, as we have seen, always troubles systems of this kind.

\section{VI.}

"Will Spinoza round out those three principles into a complete system of negative philosophy?" The answer is, that he did not. And that sets us two problems. First, why did he not? Secondly, what did he do instead?

Why he did not is easy to see. In the first place, as we have already so fully seen, in a philosophical development of this kind, no sooner do you reach an abstract Absolute, than you have a great theoretical problem on your hands. The finite and manifold world comes battering at your gate. And with this problem, in one form or the other, you must deal. For if you say that the finitude and manifoldness which separate us from the One are really nothing at all, and that therefore we really are not separated at all, are not really finite, are not really manifold; then the answer comes: "But we seem to be finite; and our world seems to be manifold and subject to change." And if you reply: "Yes, but that seeming is an illusion," then you are still in difficulty. For at once the question arises: "In a One which is absolutely without division, without change, without negation, in a One which is eternal and perfect, how has such an illusion come to be?"

Zeno, indeed, and even the Vedântists, could cut through this by an easy method-by involving the objector himself in self-contradictions. But such a way of escape was not in accordance with Spinoza's temper. And moreover, in the Europe of his day, there was an influence at work which gave to the problem now in question an almost overpowering weight. Since the Renaissance the manifold world had been taking hold on men as never before. With regard to a vast variety of interests, the soul of man had been kept " asleep" 


\section{THE METAPHYSIC OF SPINOZA}

for no small number of centuries, and now in its awakening was intolerably "hungry." For one thing, men were turning with almost passionate eagerness to the study of the physical order of nature. And their devotion to such inquiries made the finite world seem to them an ordered and veracious thing, whose reality was not lightly to be disputed. It should be noted, too, that they were devoting themselves particularly to those mathematical studies upon which any scientific conquest of nature that is to be secure, must be based. And in these mathematical and physical studies certain great ways of viewing things were brought very decidedly forward. First, there was the feeling that what explained the world was present in the world. Its laws and causes were immanent laws and causes. In your search for explanations you were not to go away from the world to something outside of it or beyond it. Secondly, there was a growing sense of the necessity of the laws operative in the world-a necessity conceived at first mathematically rather than mechanically or physically, in so far as there is a distinction between these points of view. ${ }^{1}$

It was not merely that Spinoza lived in an age which was resounding with the work of such men. It was not merely that he numbered such men among his friends and correspondents. ${ }^{2}$ It was not merely that his mind was so large and open that it could not turn a dead surface toward any great intellectual influence, and so sincere that it could not lightly dismiss any great difficulty. But it was that he himself, in a very true sense, was one of these men. This scientific tendency, with its devotion to the manifold world, with its view of that world as genuinely real and the home of eternal laws and inviolable necessities-this tendency possessed Spinoza's soul to its very core. Not that it made him a physicist. But it exercised a great influence on his metaphysical thinking. In a word, the tendency which once had been great in the world, and the tendency which was now coming to be great in the world-the tendency which moves away from the manifold world to an abstract Absolute, and the tendency which sees the manifold world actuated by an immanent and inviolable

\footnotetext{
1 Cf. Pfleiderer, Philosophy of Religion on the Basis of its History (Eng. tr. from 2nd German ed.), pp. 40, 41.
}

2 E.g., Christian Huyghens-or even Oldenburg. 


\section{THE METAPHYSIC OF SPINOZA}

necessity-had come face to face; and their battleground was the soul of this Jew. But in that calm and self-disciplined mind there was no outcry or tumult. The result simply was that by the side of that "first metaphysic" which we have been studying, there arose another. This we may call Spinoza's "second metaphysic."

The leading principles and the inner structure of this second system, it must now be our task very briefly to study. This we can most conveniently do by considering two chief topics: first, the method upon which Spinoza, in this part of his thinking, worked; secondly, the "world-scheme" built up by the use of that method. And in dealing with the latter we shall have to discuss the relation of this "second metaphysic" to the "first metaphysic"; for Spinoza himself regarded his thinking as a single system, and did not believe that its leading factors and principles fall apart into two or three distinct systems.

The significance of the method which Spinoza followed in this second metaphysic of his may be brought to clearer light by a comparison. When men of science fling themselves upon the manifold world of our experience, in the endeavour to make it intelligible as a manifold, the process which they carry through is one of discovering unity and eternity in that manifold. That the facts of the world change on our hands, that they are one thing at one time and another thing at another time, is precisely what makes men of science dissatisfied and sets them at work; they cannot leave facts, and the successive changes of facts, standing isolated. They link them together by searching for-and actually discovering-those permanent and unchanging relations, the formulations of which we call "laws of nature." And in this labour there can never be rest, until the whole manifold world is seen as a single system:-is seen as a unity which is also an eternity; for the principles which mediate the unity, and govern all the manifoldness and change, are eternal principles.

But to say this is to say that the method of scientific men is a ó $\delta$ 's $\not$ " $v \omega-\mathrm{a}$ "way up." They begin with particulars, opaque, fragmentary, evanescent, altogether unsatisfactory to the intellect. But from these they climb up to continually wider views of the laws which are operating in them. And as they thus go up, they carry the 


\section{THE METAPHYSIC OF SPINOZA}

particulars along with them; and these become transformed-become, at each upward step, more stable, more law-full, more satisfactory. in every way to the intellect. Then, if in this process we reach a point where the whole system of existence is seen as transparently intelligible-is seen as rational through and through-we can, if we

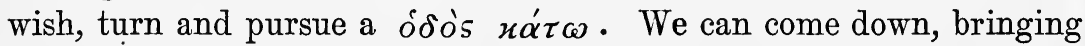
our highest light with us, and illuminating particular spheres of existence with it. But-a point particularly to be noted-we can thus "come down," only because we had first laboured through the "way up." For precisely the value of that "highest idea" to which the upward way led us, precisely the feature of it which makes it possible for us so to apply it as we "come down," lies in this, that as we worked through the "way up" we found it in the particulars, and gradually disentangled it, gradually brought it out into a light that grew clearer as we went higher. Precisely the reason that we can apply the highest idea as we "come down," is that it is not some new thing, brought down from above and alien to the facts. On the contrary, it was always in the facts. The only difference is that in "coming down" one is applying with clear and easy intelligence something which in "going up" one was gaining with pain and trouble.

The "way up" is what nowadays we usually call the "synthetic method." Really it is a method of combined analysis and synthesis. ${ }^{1}$ The "way down" on the other hand is a method of pure analysis, made possible by preceding synthesis. Historically, however, the analytic method has frequently attempted to stand alone, and in so doing has played in human thought a great but not altogether a happy part. Standing thus alone, it is cut off from its true source and support; its conjunction with the "way up" is broken; and then it becomes a method peculiarly dangerous-all the more dangerous, that it is exceedingly attractive to just such minds as Spinoza's. In this form, it starts with some idea as a premiss, and confines itself strictly to the task of getting out of that premiss what is in it. All matter not contained in that original premiss must with the utmost severity be kept out of the conclusion. And if any such matter does

1 There are people who take a perverse pleasure in calling it " the inductive method." But thc historical English use of the term "induction" unfits it for such an application. 


\section{THE METAPHYSIC OF SPINOZA}

creep in, the method considers itself to that extent to have failed. But of the "synthetic method" almost the opposite is true. It is precisely the mark of this method to get more into the conclusion than was apparent in the original point of departure. For it recognises that its proper business is to get "ideas" (or categories) and "facts" properly joined together; and this process of bringing to facts the ideas that illuminate them and that draw to light the reason hidden in them, grows continually both in breadth and in depth as it goes on. The material dealt with in any given investigation comes to mean more and more as the investigation goes on. The original premisses are being continually "reconstituted." The "ideas" get both' deeper and wider-increase both in connotation and in denotation. And the "facts" continually take on wider relations and greater significance. With the "analytic method" the object of investigation remains fixed, fast, unchangeable from the beginning. With the "synthetic method," the more you deal with the object of investigation the larger it becomes under your hands.

The analytic method in that strict form Spinoza deliberately adopted. About the question of method he had thought seriously, and in the treatise De Intellectus Emendatione gives us his conclusion on the subject-his Organon. The treatise may be described as, among other things, a plea for the use of the "way down" without any "way up"; at least, without any "way up" in the sense described above. There is an "origin and source of the whole of nature," from which, as one may put it, the whole process of nature flows down. And if we are to have a "faithful image of nature," our mind must have a highest idea which represents that origin and source, and then, from that highest idea, must deduce the whole descending series of ideas which will accurately represent to us the process of nature. ${ }^{2}$ Furthermore Spinoza thinks-or rather, he seems to take for granted-that if we are to have a " faithful image of nature," the logical movement of our ideas must proceed in the

1 See Martineau, Study of Spinoza (1882), p. 46 seq. The fact (ibid. pp. 48, 49) that the De Intellectus Emendatione; which originally had taken the lead of the Ethics, was gradually dropped, and at last left unfinished, is very significant. As it is, the treatise ends with a problem which, upon the basis there laid down, is impossible of solution.

2 Elwes, vol. II., pp. 15, 16. 


\section{THE METAPHYSIC OF SPINOZA}

same direction as the logical ${ }^{1}$ movement of nature. Just as the whole process of nature flows down from its "origin and source," so must our ideas flow down from the highest idea which represents that "source." It does not seem to him permissible that our mind should reverse the order; should, in attempting to form a "faithful image of nature," begin with the lowest particulars and run backward along the course of their outward flow from their "origin," and so form at last a " highest idea" corresponding to that "origin."

This, it is true, at once raises the question: "But how, without such a $\delta \delta \delta s \not ̈ v \omega$ as has been described, are you to get that highest idea at all ?" And Spinoza actually does consider this difficulty under one of its specific forms. He imagines an objector to say: "In order to be certain that your highest idea is really a true idea, you will need a proof. But that will call for a still higher idea; in fact, will lead to an infinite regress and so reduce the whole situation to absurdity." Spinoza's answer to the mere demand for "proof" is very admirable. But he does not see the deeper question which is involved. His answer comes to this: "Supposing a man to have gained that idea, and to be actually using it in the victorious rationalisation of nature-such a man would not be troubled at all about your miserable question of proof." "Truth would make itself manifest and all things would flow, as it were, spontaneously toward him."'2 But the very finality of his answer to the mere brute demand for proof apparently blinds Spinoza to the fact that he has nowhere clearly and consciously told us how we are to get that so indispensable " highest idea."

But then, how, on his own method, is he to construct a worldscheme? If he is to do so, a highest idea he must have. And since he actually has done so, a highest idea presumably he $d i d$ have. The answer is that he did have a highest idea, and did proceed from it to the elaboration of a world-scheme. But the way in which he got at that highest idea was peculiar. In part it was the outcome of a long course of reflection, the process of which had, so to speak, died away, leaving the conclusion standing out like a self-evident and eternal

1 For with Spinoza the movement of nature is a logical movement.

2 Elwes, vol. II., p. 16. 


\section{THE METAPHYSIC OF SPINOZA}

truth. This conclusion he formulates into a certain number of definitions-two or three of which contain the gist of the whole matter-and puts these at the head of his world-scheme just as Euclid put his axioms at the beginning of his book on geometry. In part, again, the highest idea was got by taking over a certain conception from that aspect of his thinking which we have called his "first metaphysic." That first metaphysic had culminated in the view that reality is One Substance. And with One Substance the "second metaphysic" sets out. As we shall see more fully a little later, these two substances appeared to Spinoza to be one and the same thing, and so he never doubts the genuine unity of his own thinking. But really the two are radically different things. The transition from the first to the second metaphysic is not the logically continuous transition from one part of a unitary system to the next. It is, on the contrary, a transition in which the central conception undergoes a most subtle, but also a thoroughly fundamental, change. The one indeterminate substance becomes the One Substance with infinite attributes. What blinded Spinoza to the greatness of this change was probably the fact that he held in both cases to his great regulative principle, Omnis determinatio est negatio-every determination (i.e., ascription of determinate limits, of definite characters and qualities) is a negation of reality. He did not see that the use which he made of this principle in the second case was really a denial of the principle itself.

With this, then, we may proceed to consider the ground-lines of the world-scheme itself, which in its elaboration constitutes the body of his " second metaphysic."

The first point which we have to consider is how he expresses that highest idea which, in the way already indicated, he puts at the head of his philosophical scheme of the manifold world. First, under the names causa sui and substantia, he brings forward the idea of a being, unconditioned and self-existent-a being which contains within itself the ground of its own existence and the ground of its own intelligibility. ${ }^{1}$ Then, under the name God, he enriches this uncondi-

1 Eth. Pt. I. defs. I. and III. Erdmann points out (Hist. Philos. Eng. tr. vol. II., p. 59) that the expression causa sui has no reference to a process of self-creation, but means "the unconditioned." 


\section{THE METAPHYSIC OF SPINOZA}

tioned and self-existent being with infinite attributes ${ }^{1}$-an attribute having been previously defined as that which the intellect perceives as constituting the essence of substance. ${ }^{2}$

Then from this starting-point, he goes on to the things which are not self-referring but are other-referring. These-the various individual (i.e., particular) things and beings of the world-are viewed as modi; that is, as limited "manners of existence" of the attributes of God. ${ }^{3}$

Furthermore, the particular way in which God expresses himself in modes depends absolutely on the necessity of the divine nature. That is to say, the system of particular things, the order of the manifold world, is an order of the strictest necessity and most inviolable law. The manifold universe, so to speak, flows down from the one source along channels absolutely determined by the nature of that source. $^{4}$ In a teleological system, it is true, there is also necessity; for the end is the supreme law of that whole process in which it is being realised. But in such a system as that now before us there is absolutely no place for teleology or for the teleological kind of necessity. ${ }^{5}$ The strict and inviolable necessity of this system is a necessity altogether a tergo.

And so the great category of this metaphysic is the category of cause. But we shall altogether fail to understand Spinoza if we take his continually recurring term "cause" in the sense in which we ordinarily use the term "efficient cause." As Erdmann points out, 6 Spinoza's term "cause" means mathematical or logical cause. His relation of "cause and effect" is our relation of "ground and consequent." In a word, the universe is to the Spinoza of the "second metaphysic," a great process of analytic logic in which the nature of God is the original premiss, from which processes of endless "causation" flow forth.

1 Eth. Pt. I., def. VI.

2 Ibid. def. IV.-Mr. Hale White translates: "that which the intellect perceives of substance, as if constituting its essence."

3 Eth. I. 25. Cor. with the ref erence to prop. 15 and def. V.

4 This is everywhere in Spinoza; but see especially his statement of the necessity of the world's procession from God, in a letter to Hugo Boxel (Ep. LIV).

5 See the Appendix to Pt. I. of the Ethics.

6 Hist. Philos. Eng. tr. vol. II., p. 58. 


\section{THE METAPHYSIC OF SPINOZA}

Such is the skeleton of this part or aspect of the thought of Spinoza. His amplification of it into a detailed system is exceedingly elaborate; and to one who simply takes his stand within it, and judges it by its own standards, offers material for almost endless question and criticism. To take a single instance: what is the relation of the One Substance to the Attributes? The definition of "attribute," so far from giving us a clear view, may itself fairly be called a nest of almost hopeless problems; problems which centre in the question of the place ascribed to the intellect in Spinoza's scheme of reality. ${ }^{2}$ But from all these questions of the internal criticism of the "second metaphysic" we must here turn away. It is not merely that the discussion of them would exceed, a score of times over, all possible limits of space. But it would scarcely be in line with the task here in hand-that, namely, of getting at the main lines, the fundamental movements and tendencies, in Spinoza's thought, and of viewing these in the light of the general history of philosophy.

Before passing on, however, one thing may be noted. Graphic illustrations of rational doctrines are usually very treacherous helps. But the attempt to envisage spatially this world-scheme of Spinoza's second metaphysic is somewhat useful. Sir Frederick Pollock's illustration, ${ }^{3}$ supplemented by that of Professor Erdmann, ${ }^{4}$ may be used. Let us imagine an infinite number of infinite plane surfaces parallel to one another (the attributes). Each of these is ruled with an intricate and continually varying pattern made up of geometrical figures of definite shapes (the modes-particular things and individuals); and the number of figures in the pattern is infinite (infinite modes). The planes are different from one another-let us say, are of different colours. But the pattern, and the changes that keep taking place in it, are identically the same for every plane. Let it be understood, too, that if you ask for the proximate "cause" of any

1 Eth. I. def. IV.

2 The two chief interpretations of the definition-which involve interpretations of Spinoza's whole world-scheme-are Erdmann's and Kuno Fischer's. More, I think, can be said for Erdmann's than is nowadays usually taken for granted. See, however, the exposition of Spinoza's position in Joachim's excellent Study of the Ethics of Spinoza (Clarendon Press, 1901), pp. 17-27.

3 Spinoza, his Life and Philosophy, 2nd ed. (1899), pp. 156, 157.

4 Hist. Philos. Eng. tr. vol. II., p. 62. 


\section{THE METAPHYSIC OF SPINOZA}

one of those geometrical figures, or of any change in it, the answer is to be given by referring to the figures around it and to their changes. That is to say, God is the source or "cause" of the whole system of the manifold world-in other words, that whole system, viewed in its unity, is God; but the proximate "cause" of any particular thing or event is to be looked for in the other particular things and events. And both these orders of causation proceed with absolute necessity.

It remains to say a word about the relation to each other of these two parts or aspects of Spinoza's thinking which have in the preceding pages been so sharply distinguished. First, let it be distinctly understood how the distinction is arrived at. As a critical reader goes through Spinoza's writings, he becomes conscious that in them there are distinct tendencies, distinct points of view. These are not set apart from each other; nor does one appear later than another. On the contrary, they are intertwined. On a single page, even in a single paragraph or sentence, they appear together. Spinoza himself does not even feel that there is such a distinction; he believes that his system is one and continuous. Yet there is such a distinction. Indeed it is more than distinction. It is contradiction. The appearance together of the contradictory views and tendencies is really only juxtaposition, only external union, never a genuine reconciliation. And what has here been attempted is to bring the distinction and contradiction out into clear consciousness, by disentangling the tendencies in question, formulating them, and thus setting them, in their systematic forms, in sharp contrast with each other.

But an objector may urge: when all this is done, are the "first metaphysic" and the "second metaphysic" really so different from each other? Have you not in each the same starting-point-unica substantia-and the same great regulative principle-Omnis determinatio est negatio? So that Spinoza's thought is one continuous system after all. The answer is, that the regulative principle is used so differently as to become really a different principle. In the one case it requires you to say that Substance has no attributes whatever. In the other it leads to the declaration that Substance cannot 


\section{THE METAPHYSIC OF SPINOZA}

have a limited number of attributes, nor attributes of a non-infinite kind. And with this the Substance itself becomes different. The Substance with which the "second metaphysic" begins is not truly the Substance with which the "first metaphysic" ends.

In connexion with this, however, there is a peculiar Spinozistic doctrine which it is worth our while to notice. Plotinus had to face much the same situation. He had an abstract One. And he also had a rational cosmogony and cosmology. But, as we saw, he had a most ingenious logical principle by which these two were enabled to live together in peace. "It," he said of the One, "is by no means that of which it is the principle." The powers and beings of the manifold universe are altogether dependent upon it. But it goes its way in the most absolute independence of them, and so retains all its characters-its negative characters-as an abstract One. ${ }^{1}$ Now there is something very much like this in Spinoza. "An effect," he says. "differs from its cause precisely in that which it has from its cause." 2 And he uses this principle to show that intellect and will, in any sense in which men use these attributes, cannot pertain to God who is the sole cause of all things. That is to say, he uses it for the very same purpose which Plotinus had served by the principle noted above; he uses it to enable the abstract One to be the source of a manifold order and yet remain an abstract One. It is an expedient closely akin to that of Plotinus; so closely akin, indeed, that it falls under the same condemnation. It is subtle; it is ingenious; but it forgets the implications of the conception itself of relation. You cannot have a relation which works only one way; which binds $\mathrm{B}$ to $\mathrm{A}$, but not $\mathrm{A}$ to $\mathrm{B}$.

$1 \mathrm{St}$. Thomas has the same problem, though a very different method of solving it. The Divine nature is characterised by simplicitas. Yet in God is a multitudo intellectorum. How can this be? St. Thomas answers by an elaborate doctrine based upon the principle that the Divine nature itself is God's forma intelligibilis; the Divine intelligence has but one intelligible form-its own nature ( $v$. infra, pp. 344, 345).

2 Eth. I. 17. echol. 


\section{THE METAPHYSIC OF SPINOZA}

\section{VII.}

So far, then, for this aspect of Spinoza's philosophy. But no sooner have we seen what it was, than we are once more face to face with a difficulty. Just as in the metaphysical views expressed by that Spinoza whose spiritual affinity is with Eleatic and Vedântist and Mystic, there was a great theoretical crux, so here, in the metaphysical views expressed by the Spinoza whose spiritual affinity is with the Renaissance and post-Renaissance men of science, there is a great theoretical difficulty. And just as in the first case that large and open and sincere mind faces the difficulty and attempts to solve it, so here does he face it and attempt to solve it.

First, let us see what the present difficulty is. It may be stated as follows.-On the one hand, in that way of viewing the world with which we have just been dealing, particular things and individual beings all stand upon a level and all are actuated from behind. Spiritual activities-the energies of thought and will-stand on precisely the same level as any natural activity. Spinoza, for instance, expressly affirms that will does not appertain to the nature of God more than any other natural thing does, but is related to it just as motion and rest and all other things are related to it; all alike follow from the necessity of the divine nature and are determined by it to exist and to act as they actually do exist and act. ${ }^{1}$ And even if Spinoza did not expressly declare this, it would still follow from the general point of view which he here holds. From natura naturansi.e., from God, the substance whose essence the intellect perceives as consisting in infinite attributes ${ }^{2}$ - follows necessarily natura naturata, the system of modes. ${ }^{3}$ And in natura naturata man stands on a level with all other things, and man's actions on a level with all other particular events. For thought is one attribute; extension is another; and, to recur to the illustration mentioned on a previous page, ${ }^{4}$ that total pattern which appears on each of these planes, and on the

1 Eth. I. 32. Cor. 2.

3 Eth. I. 29. schol.
2 Eth. I. defs. VI. and IV.

4 P. 173, supra. 


\section{THE METAPHYSIC OF SPINOZA}

infinite number of other planes, flows from and is absolutely determined by the necessity of the divine nature. To give a precedence to any one of the attributes, or to break down their absolute independence of one another, their absolute separateness, would be to forget the essential principles of this "second metaphysic."

But on the other hand there is something which compels us to do just those things-to give a precedence to one of the "attributes," and to break down their separation. What this is, we must now consider.

First, as we have already seen, ${ }^{1}$ in our experience subject and object are correlative. The consciousness of objects and the consciousness of self are necessary each to the other; if either be taken away, the other vanishes; and the development of the one is the development of the other. But such correlation and such organic union imply community of nature; imply that a single principle is manifesting itself in each of the members of the relation. There is, that is to say, community of nature and of principle between the world given to us in experience and the self that knows the world and acts in it and upon it. But what is that common nature of the self and of the world? This question we could answer if we "knew from within" either of the members of the relation. And one of them we do know from within; as self-conscious, we know by inner awareness the nature of the self. So that precisely in the self lies the key to the nature of the world. That principle or energy of which the human soul is an inchoate form-the principle frequently in philosophy called "thought,"2 but for which "spirit" is an apter name-is the principle of the whole objective order, including the order of extended things and any other order of being with which man's intelligence can enter into relation. In other words, the unity of the world-the world in the greater sense of the term, as that system of things in which the human soul is an element-is the unity of a single self-conscious experience in which, through manifoldness

1 Supra, pp. 2, 3 ; and 65. Cf. infra, pp. 208, 209.

2 In the sense of that total activity in which psychologists sometimes distinguish "feeling," "intellect," and "will":- a usage of the term "thought" which is convenient, and dignified by long custom, but open to misunderstanding. 


\section{THE ME'TAPHYSIC OF SPINOZA}

and diversity, through the shock of conflict and the discipline of unfathomable sorrows, there is being realised an ideal end, a "far-off divine event,"

-the love:

Toward which all being solemnly doth move. ${ }^{1}$

But from this certain consequences follow for the view of the world expressed in Spinoza's " second metaphysic." First, the nature of the manifold world is emphatically not the nature set forth by Spinoza in this aspect of his thinking. The process which is the life of spirit is not a process guided by a necessity that acts absolutely a tergo. On the contrary, it leads itself on from before. It presents ideal ends to itself, and to these it seeks to give being in the world of achieved realities. True, the world, as a spiritual process, has necessity in it. But it is the necessity which arises out of the fact that the ideal end is itself the supreme law of that process of development of which it is the culmination and fulness. And since the source alike of that end and of that necessity communicates its own nature to men, men are able to adopt that necessity as the law in which their own being finds its fulfilment. So that, on the view ultimately given by this tendency, necessity itself is enlisted as a good soldier "under the banner of the free spirit." 2

But secondly, this same process-the life of spirit, or, as Spinoza

1 Arthur Henry Hallam, Sonnet On the Picture of the Three Fates in the Palazzo Pitti at Florence.

2 Coleridge, in his marginal annotations in Crabb Robinson's copy of Spinoza, has an interesting reference to Spinoza's doctrine of necessity, in which he does justice to Spinoza's distinetions of immanent necessity from external compulsion. Commenting upon Eth. I. 28. he says: “ . . . It is true he contends for Necessity ; but then he makes two disparate classes of Necessity, the one identical with Liberty, . . . the other, Compulsion=Slavery. If Necessity and Freedom are not different points of view of the same thing; the one the Form, the other the Substance, farewell to all Philosophy and to all Ethics. It is easy to see that Freedom without Necessity would preclude all Science, and as easy to see that Necessity without Freedom would subvert all morals; but though not so obvious it is yet equally true that the latter would deprive science of its main Spring, its last ground and impulse ; and that the Former would bewilder and atheize all morality. But never has a great man been so hardly and inequitably treated by Posterity as Spinoza. . . ."

My attention was called to Crabb Robinson's copy of Spinoza (and to Mr. Hale White's publication of Coleridge's annotations, in the Athenceum, No. 3630, May 22, 1897) through a charming act of kindness on the part of Miss Lucy Toulmin Smith to a stranger who one day entered as a visitor the Library of Manchester College. 


\section{THE METAPHYSIC OF SPINOZA}

calls it, the "attribute" thought-cannot be placed as Spinoza places it, simply on a level with the other aspects of reality like extension. Men cannot be viewed as standing on a level with " all other natural things"-as having merely the same relation to the ultimate unity that "motion and rest" have. On the contrary, the unity of existence lies in the fact that the world is constituted by an eternal spirit; and we men have, as the essence of our being, a nature and an activity which are our own and yet are His nature and activity communicated to us. We are, so to speak, lesser centres in that system of which $\mathrm{He}$ is the supreme centre. He is in us, and we live in His life. Through us, or rather in us and our experience, $\mathrm{He}$ is realising an eternal purpose; and we, in that loyalty to domestic and social and civic duties which is the indispensable basis and content of all goodness, but which has not become fully itself until it has risen to the form of the conscious love of God, can adopt that purpose of His as our purpose, and thus enter more and more upon the fulfilment of our vocation as sharers in the divine nature and the divine life.

So that thought itself bears witness against the place which Spinoza has assigned to it in the world-scheme of his "second metaphysic." And this witness is borne by all the phases and aspects of that thought which is our experience. It is involved in the possibility of knowledge. It is involved in ordinary or "individual" morality. It is involved in those great structures and far-reaching activities which we denote by such terms as "the state" and "religion."

Such, then, is the situation which the Spinoza of the "second metaphysic" has to face. What will he do? One thing, it is evident, we must not expect. We must not expect him to enter upon the reflective mastery of the whole situation by grasping, the insight just noted, and explicating it into a system of metaphysic. That was left for the men of a later day; Spinoza must bring Cartesianism to its goal before the new era could begin. Descartes had broken the cogito into two, and it was but natural that Spinoza should harden the division. ${ }^{1}$ To see the

1 This is one of the chief points upon which Coleridge fastened, in the annotations referred to above (p. 178, note). "Spinoza begins," says Coleridge, "with the Phantom of a Thing in itself, i.e., an Object. But an Object implies a Subject as much as a S. an O.; therefore that only can have a chance of grounding knowledge, which assumes the actual fact, namely $\mathrm{X}=$ Subject-Object=Object-Subject, Ideal-real, real-ideal ! the Absolute: 


\section{THE METAPHYSIC OF SPINOZA.}

cogito restored fully to its rights and credited with the whole of its own possessions, we must wait for Kant and Kant's successors. But still a certain degree of advance in this direction was possible to Spinoza. For in certain of the aspects or manifestations of thought, the witness which it bears to itself is specially emphatic. Three such aspects may be noted here; in actual experience inseparably interconnected, and distinguished here only for convenience of statement. First, there is morality as in the individual man. Secondly, there is the morality seen in the ideals and regulative principles that operate in the life of the state. Thirdly, there is religion. These-all of them works of thought, ${ }^{1}$ and all of them expressing the innermost nature of thought-stand at the gate of any philosophical scheme of reality, demanding admission and requiring that a place be made for them which they can occupy without laying aside their essential characters. This demand in its fulness Spinoza could not apprehend or grant; to do so would have been to effect that total transformation of the philosophical scheme of things, which became possible only after Kant and the Kantians had restored the cogito to its rights. Something, however, Spinoza could do; and that he did. It was never his habit to close his great intellect against any demand of scientific sincerity. He listened to the demand now in question, and did the best he could to meet it. The result was that he advanced to flashes and glimpses of insight, and occasionally even to rather fully articulated doctrines, which represent, or imply, a view of reality different from either of the two which we have so far seen in him. Keeping to the expression already employed, we may call this part or aspect of his thinking his "third metaphysic."

The relation of this third metaphysic to the other two, it will be understood, is much the same as that of those to each other. In Spinoza's thinking they are intertwined. They appear together often

eternally foliating the Dual [so Coleridge goes on in his attempt at a speculative doctrine of the Trinity] as this the Triad. Being + the Word = the Spirit, and then the mystery or Love $=$ God all in all when he hath finally submitted himself to whom all things had been submitted" (from the annotation of Kp. II.-Spinoza to Oldenburg). Compare with this, a sentence from the comment upon the reference to Nero's crime in Spinoza's third letter to Blyenbergh: "The truth is, Spinoza, in common with all the metaphysicians before him (Böhmen perhaps excepted), began at the wrong end-commencing with God as an Object."

1 In that greater sense of the word already noted (= rational spirit). 


\section{THE METAPHYSIC OF SPINOZA}

on the same page, sometimes even in the same sentence; and are never observed to speak hostile words to one another. Yet this apparently so close union is only external. In reality they are citizens not merely of different, but of deeply severed, kingdoms; to genuine reconciliation and unity they never come. If it had been Spinoza's fate to occupy a position similar to that of Socrates-to stand at the head of a great philosophical succession which included in itself virtually all the serious and disinterested thinkers of the age-we should probably have found in that succession three great schools, as distinct from one another as were those which alike claimed Socrates as their head.

Let us consider, then, the chief discussions and doctrines which constitute this "third metaphysic." It would be very interesting to study those occasional phrases scattered through his writings, which have a bearing on this. For instance, in the very first sentence of the De Intellectus Emendatione we find him resolving " to inquire whether there might be some real good having power to communicate itself." A few pages farther over we find him mentioning " the union existing between the mind and the whole of nature." In the mouth of a Kantian-or of a Platonist-such conceptions would have an immeasurable, a world-penetrating, significance. But we should go astray if we supposed that they had so great a meaning for Spinoza. We shall be on safer ground if we turn at once to his discussion of those three great works or expressions of thought, in which the inner nature of thought simply forces itself on the attention of the observer; to his discussion, namely, of individual morality, of the state, of religion.

His elaborate discussion of the first of these cannot be reproduced within the limits of these pages. Nor is it necessary that it should. For it is only with the ground-lines of the discussion, only with its controlling conceptions, that we are specially concerned.

These amount to a virtual bringing back of that ideal point of view, and of those teleological categories, which in the "second metaphysic" had been driven into extremest exile. This we may see by considering the three main topics of the discussion: $:^{1}$ first, the con-

1 Topics which are, of course, most closely interconnected. 


\section{THE METAPHYSIC OF SPINOZA}

ception of the moral good; secondly, the doctrine of man's freedom; thirdly, the discussion of the way of attaining to that freedom and that good.

Under the first of these three topics we have to consider in especial two great conceptions: that of the "summum bonum"; and that of the "conatus in suo esse perseverandi." You, as a man, have a given esse or nature, and it is your summum bonum to maintain-or rather, as we shall see presently, to realise and fulfil-that esse. It is true that the mere use of these two phrases does not necessarily introduce a new point of view. For the summum bonum might be defined to consist simply in your position as a necessitated mode of one of the attributes; and the esse, likewise, as consisting simply in the nature given you by that position. But precisely the key to the situation is that that is just how Spinoza does not conceive them. The esse is conceived, not as the nature given you by your mere position as a necessitated mode in the great "causal" series, but as something against which that position wages war and which you have to maintain in the face of that position. And that maintenance, that fulfilment of your nature in the face of an implacably hostile situation, is your summum bonum.

This, however, we must consider in slightly greater detail. First of all, in man a great dualism of reason and passion is affirmed. ${ }^{1}$ But, secondly, while the one side of this represents our position as necessitated modes in the great causal nexus of modes, it is precisely in the other side that our summum bonum is to be sought. "Inasmuch as the intellect is the best part of our being," says Spinoza in the remarkable fourth chapter of the Tractatus Theologico-Politicus, "it is evident that we should make every effort to perfect it as far as possible if we desire to search for what is really profitable to us. For in intellectual perfection the highest good should consist." "Since," he argues in the Ethics, " this effort of the mind wherewith the mind endeavours, in so far as it reasons, to preserve its own being, is nothing else but understanding; this effort at understanding is the first and single basis of virtue, nor should we endeavour to understand things for the sake of any ulterior object . . ." "We know nothing,"

1 Throughout Pts. IV. and V. of the Ethics.

2 IV. 26. dem. 


\section{THE METAPHYSIC OF SPINOZA}

runs the next proposition, " to be certainly good or evil, save such things as really conduce to understanding or such as are able to hinder us from understanding." Again, "In life it is before all things useful to perfect the understanding, or reason, as far as we can, and in this alone man's highest happiness or blessedness consists . . . " And since the good lies in understanding, it follows that "the mind's highest good is the knowledge of God, and the mind's highest virtue is to know God."2 So, then, in this dualism of reason and passion, the good lies altogether within one of the two sides. And the other side-the side which wars against our attaining of this good, and, in so far as it prevails, constitutes our "bondage"-is, as was said a moment ago, just what represents our place as modes in the great nexus of modes. For the passions are the ways in which external causes act upon us. ${ }^{3}$ That is to say, they represent man as the "second metaphysic" must represent him altogether; namely, as one mode altogether determined by the "causal" activities of the other modes. Spinoza states both sides of this dualism very strongly. The " bondage of man" he states so strongly-i.e., in stating it he clings so closely to the point of view of his "second metaphysic"-that he makes it quite hopeless. ${ }^{4}$ But he states the other side just as strongly. And that he does not consider the bondage hopeless he still further shows by describing the way in which man is to deliver himself from it, and so to attain his good.

This brings us to the second of these topics, Spinoza's view of freedom, which is really nothing other than his conception of the Good stated from a special point of view. To study it for its own sake would be to undertake one of the most interesting and most instructive tasks in the history of philosophy. But here, once more, for the purpose of our present discussion we may sum up the matter in a sentence or two. Spinoza conceives the freedom of man to lie precisely in man's fulfilling the law of his own being and living out his own true nature, unshackled and undisturbed by those "external causes" to which reference was made above. But we have just seen how

1 Eth. IV. Appendix (IV.).

2 Eth. IV. 28.

3 See Eth. IV. 5. Cf. the Corollary of the preceding proposition.

4 In Eth. IV., take the Axiom along with propositions 3, 4, 5, 6, 7. 


\section{THE METAPHYSIC OF SPINOZA}

Spinoza conceives that true nature of man and that true law of man's being. He conceives them, namely, in a way which goes far beyond the point of view of the "second metaphysic," and makes no slight advance in the direction of restoring to the cogito its true meaning and its true place and function in the universe. ${ }^{1}$

And, as we might expect, we find the same tendency in Spinoza's discussion of the third of these topics-the way of attaining to freedom and the Good. We need not, however, dwell long upon it. It is enough to say that Spinoza shows at length how the realm of the understanding is to be extended over the realm of the passions $;^{2}$ in other words, how we men are to break away from, and to rise above, the position to which we would be absolutely confined if we were really the "modes" which the "second metaphysic" holds us to be. Reason, when it has risen through the ascending stages of knowledge, ${ }^{3}$ comes to that union with God-that union with "the whole of nature"-in which it sees all things under the aspect of eternity and necessity; and learns to accept them, because when thus seen they are seen as parts of perfection. But it accepts them, not as a mere mode accepts them-i.e., as an external fate; in accepting them, it acts from within and of its own accord; for it has risen to the point of view of the eternal, and so accepts them not only as good, but as being its Good-that in which it fulfils its nature. And this state of the soul-in which it is no longer swayed hither and thither by those forces from without which act on us through the passions, but is guided solely by that highest form of reason-is freedom.

So much, then, for the question how far Spinoza, in dealing with individual morality, introduces a new and higher point of view into his system. Next we have to consider the same question with regard to his treatment of the state and of religion.

1 Spinoza's conception of freedom, in its elaborate form, is of course to be looked for in the latter part of Eth. IV. and in Eth. V. But it comes forward in many passages in his writings-passages often remarkable for a keenness and brilliancy that contrast strikingly with the general calm of his pages. See, for instance, Tract. Theol.-Pol. cap. IV. (Elwes, vol. I., pp. 58 and 66); letter to Isaac Orobio (Ep. XLIX.) with which cf. the keen outburst in Eth. V.41, schol. ; and especially Tract. Pol., II. \& 7, and the letter addressed to Schaller dealing with Tschirnhausen's objections. (Ep. LVIII.)

2 See the earlier part of Eth. V.-specially the scholium to proposition 20.

3 See pp. 191, 192 infra. 


\section{THE METAPHYSIC OF SPINOZA}

In Spinoza's discussion of individual morality, we were specially concerned to note how the view there taken by him lifted men above the position of mere modes of one of the attributes. So far as this went, it constituted a recognition alike of the true nature of the cogito and of its true place and function in the system of reality. Now, if Spinoza holds to the new point of view, as he advances from the individual to the state, this recognition will be made both deeper and wider. The whole insight, so to speak, will move in a wider field, and thus the process of restoring the cogito to its rights will be carried onward toward its conclusion.

For the state is one of the great works of the cogito; or, to employ more modern language, it is a great structure of objective reason. The long process of the formation of the state is one in which the rational spirit has struggled and still is struggling, to work out a form of organised society in the life of which that rational spirit will find its own true home, will fulfil the law of its own being, will realise its own essential and eternal nature. Hence, the state is not something external to man. Nor do its laws ultimately represent a mere compulsion from without. On the contrary, it is only by living the life of a member of the state that man truly becomes man at all. And his political freedom consists precisely in belonging to a state whose laws are such that he can adopt them as his own laws and find in them his guide toward the fulfilment of his own nature.

Under certain limitations this view of the state was taken for granted by Greek citizens; still more by Greek men of thought. Freed from the Greek limitations, it received an elaborate and systematic formulation from Hegel. And by at least one statesman of modern days it was thrown into the language of practical politics-in Burke's great saying that the state is not a contract limited to man's lower interests, but on the contrary is " a partnership in all science, a partnership in all art, a partnership in every virtue, and in all perfection."

But Spinoza, when he passes from the consideration of individual morality to the consideration of the state, does not make this advance. And the reason why is plain. In that very consideration of individual morality, he conceives the good, as we have just seen, in a thoroughly 


\section{THE METAPHYSIC OF SPINOZA}

intellectualistic way. Now, an intellectualistic good is not a selfish good. Nor is it an individualistic good in the sense that the obtaining of it by one man prevents the obtaining of it by others. But it is individualistic in the sense that it can be realised by men who stand almost alone; who live, as Spinoza himself did, in comparative solitude. It is not necessarily a good the very striving after which leads to, and is fulfilled in, the building up of great social structures and the establishing of great social institutions.

Moreover, the view which Spinoza takes of the whole cogito is in accordance with that intellectualistic view of the good. When the will is reduced to intellect; ${ }^{1}$ and when, in the peculiar way described by him, the intellect extends its domain over the emotions and passions :then the cogito which is left is not one which is driven forth by its own nature to social activities, nor one which can find its true home only in the life of an organised society.

Hence in Spinoza's views concerning the state we must not look for any great advance in the direction indicated above. First, indeed, we shall see that certain of his political positions do look in that direction. But we shall have also to notice that in his latest writing, the Tractatus Politicus, a theory comes forward which almost supersedes those and swings far backward toward the point of view of the "second metaphysic."

First, then, for the positions which imply the view that the state stands in organic relation to the individual, and that therefore he who would be truly a man and would truly realise man's nature, must live in the state and perform the functions of a citizen.-These are found particularly in the Tractatus Theologico-Politicus. For instance, in the fourth chapter, ${ }^{2}$ he refuses to regard legislation as in its genuine nature a force acting on the citizen from without. He rises to one of his rare invectives when he speaks of those whose object in obeying law is merely the avoidance of punishment. But the man who follows the precept suum cuique, not because he fears the gallows, but "from a knowledge of the true reason for laws and their necessity"-

1 See Eth. II. 49. Cor. Spinoza here says that the will and the intellect are one and the same thing. But, with him, that virtually means the reduction of the will to intellect.

2 Elwes, vol. I., p. 58. 


\section{THE METAPHYSIC OF SPINOZA}

he it is who "acts from a firm purpose and of his own accord, and is therefore properly called just." Again, in the sixteenth chapter, in dealing with the duty of subjects to obey the commands of the sovereign power, he remarks: "That state is the freest whose laws are founded on sound reason, so that every member of it may, if he will, be free; that is, live with full consent under the entire guidance of reason."

And the attitude revealed in such hints as those is carried still farther in what we may call his theory of the relation of church and state. "God," he says, " has no special kingdom among men, except in so far as He reigns through temporal rulers." "It is only through" those who possess the right of ruling and legislating "that God rules among men, and directs human affairs with equity." 3 Thus "secular rulers are the proper interpreters of divine right."4 But from this it follows that the sovereign rulers "are the proper interpreters of religion and piety." "If we would obey God rightly," "the outward observances of religion and all the external practices of piety should be brought into accordance with the public peace and well-being." "We cannot, therefore, doubt that the daily sacred rites . . . are under the sole control of the sovereign power; no one, save by the authority or concession of such sovereign, has the right or power of administering them, of choosing others to administer them, of defining or strengthening the foundations of the church and her doctrines; of judging on questions of morality or/acts of piety; of receiving any one into the church or excommunicating him therefrom, or, lastly, of providing for the poor." 7 With these passages may be taken one of wider scope from the last chapter of the treatise."It follows plainly from the explanation given above of the foundations of a state, that the ultimate aim of government is not to rule or restrain by fear, nor to exact obedience, but contrariwise to free every

1 Elwes, vol. I., p. 206.

2 Tract. Theol.-Pol. cap. XIX. Elwes, vol. I., p. 245.

3 Loc. cit. Elwes, vol. I., p. 248.

4 Loc. cit. Elwes, vol. I., p. 249.

5 Loc. cit. Elwes, vol. I., p. 249.

6 Loc. cit. Elwes, vol. I., p. 249.

7 Loc. cit. Elwes, vol. I., p. 252. 


\section{THE METAPHYSIC OF SPINOZA}

man from fear, that he may live in all possible security; in other words, to strengthen his natural right to exist and work without injury to himself or others. No, the object of government is not to change men from rational beings into beasts or puppets, but to enable them to develop their minds and bodies in security and to employ their reason unshackled; neither showing hatred, anger or deceit, nor watched with the eyes of jealousy and injustice. In fact, the true aim of government is liberty." 1

The view of the organic relation of the individual and the state implies not only a doctrine as to what the function of the law is and as to why we should obey the law. It implies also a doctrine concerning the width of state action: whatever the state can do to enable its individual members to live truly human lives and to fulfil the nature of man, that the state ought to do. The Spinozistic views just noted lean toward a doctrine of this kind. But Spinoza never works his way to a clear possession of it. Alongside such passages as those referred to in the immediately preceding paragraphs, stand others wherein Spinoza regards the function of the state as limited to the securing of peace, and the guarding of the individual against the hindrances of violence and disorder. "By human law," he says in the fourth chapter of the Tractatus Theologico-Politicus," "I mean a plan of living which serves only to render life and the state secure." And in the Tractatus Politicus he says: "The quality of the state of any dominion is easily perceived from the end of the civil state, which end is nothing else but peace and security of life. And therefore, that dominion is the best where men pass their lives in unity and the laws are kept unbroken."3 Though even here it is fair to note the qualification which he presently adds:" "When, then, we call that dominion best, where men pass their lives in unity, I understand a human life, defined not by mere circulation of the blood, and other qualities common to all animals, but above all by reason, the true excellence and life of the mind."

1 Tract. Theol.-Pol. cap. XX. Elwes, vol. I., pp. 258, 259.

2 Elwes, vol. I., p. 59.

3 Tract. Pol. V. \& $2 . \quad$ Elwes, vol. I., p. 313.

4 Ibid. cap. V. \$5. Elwes. vol. I., p. 314. 


\section{THE METAPHYSIC OF SPINOZA}

But finally, as was said above, we come, at the opening of the Tractatus Politicus, upon a doctrine which swings decidedly back toward the point of view of the second metaphysic. This is the great doctrine that natural right is "potentia"; and this doctrine roots itself directly in the view that man is "pars naturae," i.e., in the language of the Ethics, a mode of one of the attributes. “ . . . Every natural thing has by nature as much right as it has power to exist and to operate; since the natural power of every natural thing whereby it exists and operates, is nothing else but the power of God which is absolutely free. And so by natural right I understand the very laws or rules of nature, in accordance with which everything takes place; in other words, the power of nature itself. And so the natural right of universal nature, and consequently of every individual thing, extends as far as its power: and accordingly, whatever any man does after the laws of his nature, he does by the highest natural right, and he has as much right over nature as he has power."1 On this ground is rested man's right over nature. "If two come together and unite their strength, they jointly have more power, and consequently more right over nature, than both of them separately, and the more there are that have so joined in alliance, the more right they all collectively will possess." ${ }^{2}$ And on no different ground is rested the right of the state over its individual members. " . . . As each individual in the state of nature, so the body and mind of a dominion have as much right as they have power. And thus each single citizen or subject has the less right, the more the commonwealth exceeds him in power, and each citizen consequently does and has nothing but what he may by the general decree of the commonwealth defend." " *. . Whatever he [each individual] is ordered by the general consent, he is bound to execute, or may rightfully be compelled thereto." 4 So that it is quite inconceivable that " every citizen should be allowed to interpret the commonwealth's decrees or laws" and thus "be his own judge."5_It will be noted

1 Tract. Pol. II. \$\$ 3 and 4. Elwes, vol. I., p. 292.

2 Ibid. II. \& 13. Elwes, vol. I., p. 296.

3 Ibid. III. \& 2. Elwes, vol. I., p. 301.

4 Ibid. II. \& 16. Elwes, vol. I., p. 297.

5 Ibid. III. (esp. \& 4-Elwes, vol. I., p. 302). 


\section{THE METAPHYSIC OF SPINOZA}

exactly why this doctrine is referred to here. It is not for the purpose of criticising Spinoza's strong assertion of the right of the state over the individual. A sovereignty of the state over the individual there must be, if civil society is to exist at all. But what we have to mark is that the particular way in which Spinoza here gains a theory of sovereignty, constitutes not an advance in the process of restoring the cogito to its rights, but rather a relapse toward the point of view of the "second metaphysic."

Let us pass, then, from Spinoza's political views to the last of the three subjects upon which we have here to touch-namely, to his conception of religion. ${ }^{1}$ If it was true that in the state we find the cngito going forth from itself and building up a great objective structure in whose life it realises its own being, even more is this same thing true in religion. For in religion the rational spirit not only builds up great objective structures. It not only organises men, and establishes customs, and founds institutions. But it does all these things, not from a point of view limited to this present life, but from the point of view of that total or eternal life which is the real life of man. That is, it tries to take the highest and ultimate point of view, and from that point of view to organise man's life and to fashion man's society. In doing this, it even seeks to make the state its minister, and to make man's political life a phase or aspect of his total, or religious, life. Nor, ultimately, can this be aroided. It is true, compromises, and divisions of the field between religion and politics, may be useful or even necessary in this present life. But ultimately religion cannot leave outside of itself anything whatsoever which is human. It must either seek to shape the whole life of man; or else acknowledge that the point of view from which it is endeavouring to organise man's life is not the highest and is not ultimate.

But it follows from this that an adequate theory of religion would complete that process which an adequate theory of the state would have carried part way:- the process of restoring the cogito to that supreme place in philosophy, from which Descartes, with the best of intentions toward it, had been the means of pulling it down. But

1 With this and the immediately following paragraphs, compare what is said on pp. 195-198 infra, concerning a contribution ultimately made to religion by the "second metaphysic." 


\section{THE METAPHYSIC OF SPINOZA}

what we have already seen will guard us from expecting any such adequate theory from Spinoza. He really has two views of the religious life, as Pfleiderer points out. ${ }^{1}$ And these both lead us back to the discussions just examined, rather than forward to a still fuller possession of the new point of view. The one refers us to the theory of the state. The other takes us back to the theory of the individual's summum bonum.

In the Tractatus Theologico-Politicus Spinoza views religion as obedience to the divine commands, as a life of practical piety. This life of piety he sunders quite sharply, indeed sunders absolutely, from philosophical insight. If it be guided by revelation, that revelation itself is received under the form of imagination, not under that of reason. And, as we have already seen, its rites and outward observances, are to be in accordance with the public peace and well-being, and are therefore to be determined by the sovereign power alone; i.e., as the rational organisation of man's life the state is both wider and deeper than the church and includes the church. Indeed, religion in this sense is doubly sundered from reason. Not only is it insisted that philosophical insight is not its basis or source (so that Philosophy and Theology stand altogether apart). But the separation is made so absolute that reason is regarded as incapable of showing us this way of salvation at all. ${ }^{2}$ So that, in what is the especial work of Spinoza's "third metaphysic" - the work, namely, of putting thought in its true place in the system of reality-this part of his theory of religion can scarcely be said to take us any farther than did his theory of the state.

But, besides this, Spinoza has another view of religion. This is brought forward in those closing pages of the Ethics where the theory of the summum bonum receives that final development which transforms it into a theory of religion. In the third of those three kinds of knowledge which he has distinguished in the De Intellectus Emendatione, ${ }^{3}$ we know things under the form of eternity; that is to say, we

1 Philosophy of Religion on the Basis of its History, (Eng. tr. from 2nd German ed., vol. I., p. 62).

2 Tract. Theol.-Pol. cap. XV. (see especially Elwes, vol. I., p. 194 and p. 198, along with Spinoza's annotation in loc.-Elwes, vol. I., p. 276 [25], Van Vloten et Land, vol. I., p. $625[\mathrm{xxxi}])$.

3 See Elwes, vol. II., p. 8 seq. Four kinds of "perception or knowledge" are mentioned in this passage ; but Spinoza usually groups these as three (see Eth. II. 40, schol. 2 ; v. 25-28, 31-33). 


\section{THE METAPHYSIC OF SPINOZA}

know them in God. But thus to know things is truly to know God. This, furthermore, is our perfection, and we joy in it. This joy is attended by the idea of God as its cause. And this, according to Spinoza's definition, ${ }^{1}$ is love. Thus arises that unselfish and disinterested intellectual love of God ${ }^{2}$ which does not expect or endeavour to be loved by God in return. ${ }^{3}$

In this intellectual love of God consists the essence of religion according to Spinoza's second conception of it. How high and pure and disinterested this conception is; how this lofty disinterestedness is seen also in his theory of immortality $;^{4}$ how in later days great poets and teachers were touched by it:- these are topics upon which any lover of Spinoza would gladly linger. To turn away from them to the work of criticism seems almost like ingratitude. Yet if we are to learn from Spinoza that which Spinoza has to teach, we must repeat even here the question which especially concerns us as we discuss his "third metaphysic." How far, then, does this conception take us in restoring the cogito to its place as a principle of philosophical explanation, and thus in giving to reason its due place in the system of reality?

The answer is, that it really takes us no farther in this direction than did the theory of individual morality. This intellectualistic religion is the bloom upon that intellectualistic summum bonum. No more here than there can reason be pourtrayed going forth from itself and building those great structures of church and state in which it realises its nature and fulfils the law of its being. This, as Pfleiderer points out, ${ }^{5}$ is the reason why Spinoza is never able to bring into organic relation the two kinds of religion which he has described: this intellectualistic religion to which men of disciplined mind may attain, and which requires no institutions; and that religion of the many, described in the Tractatus Theologico-Politicus, which has a revelation, and institutions, and a social organisation. ${ }^{6}$

1 The sixth of the definitions of the emotions appended to Eth. III. Cf. III. 13. schol.

2 Eth. V. 15.

3 Eth. V. 19.

4 Eth. V. 21-23, 29-31, 38-40, and specially 41.

5 Op. cit., (Eng. tr., vol. I., pp. 65, 66).

6 Now that the three tendencies in Spinoza's thinking are before us, the position of the second relatively to the other two may be indicated in this way:-It stands midway 


\section{THE METAPHYSIC OF SPINOZA}

\section{VIII.}

Such, then, was the place occupied by Spinoza in that process of development which is the history of philosophy. Descartes, standing in the forefront of a new age and seized to his heart's core by its spirit, had attempted to take his stand as if at the very beginnings of science; had attempted to free himself from all assumptions, and to show forth the bare fact as he found it. He could not, it is true, annihilate the past. He could not put himself back where Vedic poet

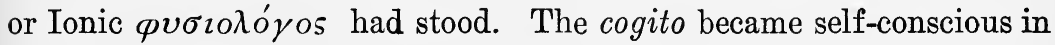
him as it could not in them. But though his material was so different from theirs, yet in dealing with it he put himself nearly upon the same logical level as they; he used the same order of categories, and so followed essentially the same method of conceiving reality. But while it was thus given to him to initiate the first stage of modern philosophy, it was not given to him to carry it through to its conclusion. To develop the full significance of the categories which dominated it; to carry its method through to a final result; to formulate this result fearlessly and uncompromisingly, turning aside for no influence either of church or of state; and thus, with the emphasis of a final word, to make clear what the ultimate outcome is of this way of attempting to get at the truth of our experience:- this was reserved for Spinoza.

between the first and the third in the sense that, in working out its view of the world as one, it keeps its hold upon certain parts and aspects of the manifold, but makes abstraction of other parts and aspects. And those of which it makes abstraction are precisely those which, as human development goes on, come more and more to be the supreme interests of men. Yet even in this (so long as the scientific interest in the details of the world remains dominant) its face must be regarded as turned toward the third rather than toward the first. For though it abstracts from the aspects of reality just referred to, and leaves no home for them in the One (and therefore cannot in their nature find a key to the nature of the One), jet it does this, not in the sense of making a conscious and intentional abstraction, such as he makes who believes abstraction to be the sole way to truth; but only in the sense that it has never seen them, has never felt the pressure of the problem which they raise. And such abstraction is likely to be overcome in the end. For if any aspect at all of the manifold be admitted into the One, the other aspects, coming forward each in its own time, may be depended upon to enforce their claims with an emphasis that increases with the deepening of human experience, and at last becomes irresistible. But the conscious and thoroughgoing abstraction which the first tendency makes is a different matter. By its very nature it lies almost beyond correction through any art of persuasion. For of what avail is logical refutation against a man who has found that human thought and speech cannot express that which alone is real, and in union with which is the only true life of the soul? 
And this alone would make him, in the history of thought, one of that small number of abiding figures with which it is the primary task of the student of the history of philosophy to deal. But there is more than that. In carrying the logic of Cartesianism forward to its conclusion, he was no Wolff rounding out the teaching of a great master and destroying its vitality in the process. On the contrary, his was an original and searching intellect, having life in itself, and driven by its own inner forces to penetrate to the elements of things. Hence it was impossible for him to stop short with that acosmic or mystic view which is the ultimate outcome of the Cartesian way of dealing with experience and the experienced world. Other types of thought found a place in his mind and won from him an adherence which was perfectly sincere: the naturalistic spirit of modern science made its appeal to him, and, in defiance of the logic which required an abstract Absolute, he made the One Substance the home of innumerable modes, and gave to each mode its conatus in suo esse perseverandi; and he even has glimpses of the Idealistic insight that spirit or reason is the reality of all things, and the active agent in all cosmic processes.

Of such an historical position the result is that he who makes Spinoza his companion makes the greatest things in philosophy his companions. On one side, he finds himself brought into touch with the austere and immemorial thought of Vedântist and Eleatic and Mystic. On another, he is linked, by affinity rather than by similarity, with that long succession of men of thought whose greatest name is still that of Democritus - the men who seek to interpret the world, or various aspects of it, by the conception of a natural necessity acting a tergo. ${ }^{1}$ And on still another side-or rather in his final attitude when he seeks to take into himself Spinoza's thought as a whole-he finds himself with his face set toward Kant, and toward that still greater man of thought who articulated Kant's deepest insight into a systematic view of the world and of the world's history.

And the way in which Spinoza's system-indeed, the way in which

1 Affinity but not similarity.-The Spinoza of the "second metaphysic" agrees with these men of science in attempting to explain the actual system of things by a necessity which (1) is immanent, (2) acts a tergo. But he differs from them in that he takes the divine nature itself as the home and seat of this necessity. He, if one may so speak, lifts his Democriteanism into the very nature of God, and values it as the true interpretation of that nature. 


\section{THE METAPHYSIC OF SPINOZA}

the whole movement from Descartes to Spinoza-thus cries out for Kant, is in one sense the most important point of all for the student of Spinoza. For if we would understand a system in which diverse aspects stand unreconciled side by side, we must gain a point of view above the diversities. We must gain a point of view from which we can see how they came to be what they are; and what the failure and yet the relative justification of each is; and how they may all be taken up into a greater and more comprehensive system which will give to each its due without sanctioning the error which each has when it attempts to stand alone and to make itself a finality. And precisely the way to gain such a point of view for the study of Spinoza is, first to make one's journey from him to Kant and Hegel ; and then from these back again to Spinoza, in order to interpret him in the light gained from those who finally satisfied the need which he intensified.

But that brings us to our last question. Let us suppose that the journey just mentioned has been made. Let us suppose that Kant and the Kantians have done their work, and that we are viewing things from the new point of view thus made possible to us. Is there not still-so our question would run-a great lesson for us to learn from Spinoza; a lesson which we can learn all the better now; which, indeed, we could not have learned properly at all had not Kant come to teach us? Leaving the purely historical interest aside, and thinking only of our own outlook upon our world, is there not still a great reason why we should continue our pilgrimages to Spinoza? A brief consideration of certain facts will show us that to this question we must give an affirmative answer.

First, since Kant and Hegel, we can no longer separate God and the world in the way which was once thought agreeable to truth and necessary to religion. We may say that God is the subject of the world; or that the world is God's thought, or God's activity, or God's objective consciousness. Or we may prefer to retain a theological term and say that the world is a continuous creation. But however we phrase it, we cannot escape from the position that God and the world stand in organic relation.

But, secondly, it follows from this that we can no longer think highly of God by thinking meanly of the world. On the contrary, to 
think meanly of the world is to think meanly of God. If, then, we would retain those high thoughts concerning God which the men of the heroic ages of religion had, we must gain high thoughts of the world such as those men had not. And there is one aspect of Spinoza's thought which helps us to gain just such thoughts ${ }^{1}$ - the aspect which comes especially forward in what we have been calling his "second metaphysic." The way upward from the mediæval view of this present world and of nature, to juster views of these, was a long and arduous way. It called for brave soldiers in the "war of the liberation of humanity." Of these Spinoza was one; and this seemingly so anti-religious "second metaphysic" was precisely one of his instruments in that war. The peculiar form of the category of cause employed in this metaphysic is indeed inadequate to the matter to be comprehended. But even with this inadequate category Spinoza makes plain the greatness of the world, and the majesty of those laws which are changeless and inviolable just because they are expressions of the necessity of the Divine nature.

"But," it may be urged, "the metaphysic in question has been the choice weapon, not of the merely irreligious, but of the positively and avowedly anti-religious, in all the great ages of human culture. Is there not something paradoxical in the statement that precisely by this metaphysic Spinoza made a great and lasting contribution to the deepest spiritual needs of man? You say that in Spinoza we have, on the one side, a man of religion-a man who expresses religion ' in its most concentrated and exclusive form . . . that attitude of the mind in which all other relations are swallowed up in the relation of the soul to God '; while, on the other side, we have a man of naturalistic temper whose business it was to explain nature as a system of necessitated modes. And then you say that it is the latter, rather than the former, who has contributed to modern religion. Surely this is paradox. Or is your meaning simply this: that modern man can gain from a naturalistic metaphysic what Spinoza himself frequently seems

1 Cf. p. vii. of the Preface to the second edition (1894) of Mr. Hale White's translation of the Ethics.

2 From the Master of Balliol's apt definition of Mysticism (Evolution of Theology in the Greek Philosophers, vol. II., p. 210). Cf. the following reference to Spinoza's "Atheism "-" In him the tendency to unity, to the infinite, to religion, overbalanced itself, till, by mere excess it seemed to be changed into its own opposite." (Philosophy of Kant, Glasgow, 1877, p. 43.) 


\section{THE METAPHYSIC OF SPINOZA}

to gain from it-the Stoic peace which arises from the very thought of the necessity that is in the world, and from the insight that no freedom is desirable except the freedom obtained by adopting this necessity as one's own law?"

No, the answer must run, that is not what is meant. The Stoic faith that the necessity of nature is the wisest and kindliest and most reasonable of all things; and the resolute peace which such faith brings:these, it is true, one can learn from Spinoza. But what is here in view is something different: this, namely,-present-day religion and theology can learn, and have learned, a lesson from Spinoza, but the lesson itself has been determined not so much by what Spinoza has to give as by what the modern world is able to receive. For the characteristic devotion of modern men is to their intellectual and practical citizenship in this present world. They cannot neglect the creature in order to find the Creator. They cannot turn away from the world; what they seek, alike in thought; in labour, in religion, is the mastery of it. It is true, indeed, as already we have had occasion to notice, ${ }^{1}$ that Mysticism is not without its place among modern men. That ancient spirit still passes to and fro, finding in solitary hearts and in quiet societies its chosen, and bidding them, if they would truly live, to lose themselves, not in the great energies of the world, but in God. And if we had among us Mystics in the greatness of the ancient pattern-a Bernard or an Eckhart-they might be powerful by the mere weight of their practical example. Their devotion to ends intangible to us, their absolute rejection of goods that we take for granted as the true goods of life, might shock and surprise us into a re-examination of our lives and into a questioning of our habitual "scale of values." But the fact remains, that from Mysticism, in the full and historical sense of the name, the modern world is virtually incapable of learning. And from this it follows at once that when modern men make a. pilgrimage to Spinoza, it is not to the Spinoza of the "first metaphysic."

But the need of which the modern world is conscious, in the realm where thought and religion meet, is this.-What is wrought into the very texture of the modern mind is the idea of natural law. Hence, 


\section{THE METAPHYSIC OF SPINOZA}

if religion is to be, not a mere partisan fighting for its existence, but the rightful and undoubted master of life, we must be enabled to see natural law as a way of God, and the uniformity of natural law as an appropriate expression of the rationality of God-an appropriate expression of a divine reason which, being absolutely perfect, cannot be capricious or arbitrary, and which is immanent in the whole of nature. I do not mean to say that this is the precise point of view taken by Spinoza in his "second metaphysic"; at any rate, it is not the form of expression there used. But it is the lesson which the wisest and most sensitive of modern leaders of religious thought have been able to learn from this aspect of Spinoza's teaching-leaders of whom Herder, who was half theologian and half poet, and, therefore, eminently fitted to learn valuable lessons in Spinoza's school, is a representative. ${ }^{1}$

Such, on this side of its history, has been the strange outcome of the thought of Spinoza. It had in it a metaphysic which, to use words already quoted, is the theoretical expression of religion "in its most concentrated and exclusive form "; and it had in it a metaphysic which for centuries has been denounced as atheistic and anti-religious. And of these two it was the latter, and not the former, which (through men such as those just referred to-men of Herder's type) entered beneficently into modern religious thinking, and helped in making possible that insight which the world needed for composing the strife between science and religion. For men who are in earnest about religion-specially for men who are concerned with its intellectual defense, or with interpreting it to new generations and changed minds - few facts are more full of instruction and of warning than this. It shows, for one thing, what mere sincerity in thinking can do. From

1 It is a lesson which can be learned also from Wordsworth ; in fact, in Wordsworth it has its highest and soundest form. And it can be learned from Goethe; but those whose good opinion is most worth having will not censure me if I prefer-though it would be a happiness to be able to use gentler words in speaking of the great German to whom all thoughtful modern men, whether they like it or no, are profoundly indebted-a single touch of the pure heart and upright spirit of Wordsworth, to all that vast intelligence, all that comprehension of the world from the point of view of art, for which the name of Goethe stands. Wordsworth's spirit not only is morally higher, but it also brings a sounder and truer understanding of the real nature of the world. For the real nature of the world is, if I may be allowed such an expression, passionately moral. And this Wordsworth knew; and so did Plato; but Goethe did not. 


\section{THE METAPHYSIC OF SPINOZA}

anything that seemed to be truth, or to be an aspect of truth, Spinoza would not turn away. No matter how austere its countenance, he not merely received it, but made it a welcome guest. And the result was that, from a seemingly "anti-religious" view, later generations learned a lesson which was in the most fundamental way serviceable to religion. And it shows another thing: apologists who imagine that religion can go forward only over the dead body of some scientific truth have comprehended neither the depth nor the breadth of that which they have taken it as their life-work to defend. Religion has few more injurious friends than those who are strong in attacking opponents, but weak in comprehending and interpreting their own position. 

PLATO AND THE FOUNDING OF IDEALISM 


\section{PLATO AND THE FOUNDING OF IDEALISM. ${ }^{1}$}

IN the pathetic and winning history of Mysticism one of the most marked features is a certain impersonality. Not that Mysticism has been without its special champions; in its history there are outstanding figures-the great and daring men of thought who clung to the hope of union with reality, even while they were formulating the worldshattering logic which puts reality beyond the reach of all the normal forms and energies of our experience. But these are not so much individual men of thought who by their own labour make their way to a new insight, and win a generation to it, and so become the founders of a school and a tradition. Rather they are voices for something wider than themselves; something that works dimly in the mind of an age, like a hidden ferment, and slowly gathers shape, and comes at last to the spoken word. When some great race finds life an unsatisfied hunger or a burden of pain; when some great civilisation, with all its skill and wealth and luxury, weighs itself in the balances and finds itself wanting; when some generation, possessed by the vision and the passion of religion, finds its established religion a thing external, ceremonial, priestly:- -then, as by an original tendency of human nature, and with no need of historical support or derivation, the temper of Mysticism arises like a spirit moving upon the face of the deep; and, having arisen, finds its prophets. It is the business of the Idealist to persuade and convince men, as best he can, under all circumstances and in every spiritual climate; but the Mystic speaks usually to hearts made ready for his word; and, to them, speaks with overwhelming power. Indeed, the passage of mystic doctrine from land to land and age to age has seldom been more aptly described

1 I am indebted to the Delegates of the Clarendon Press for the generous permission which has enabled me to quote from Jowett's translation. 
4.

\section{PLATO AND THE FOUNDING OF IDEALISM}

than by Professor Royce, ${ }^{1}$ when he calls to our minds the words of Coleridge's Ancient Mariner:

I pass, like night, from land to land;

I have strange power of speech;

That moment that his face I see,

I know the man that must hear me :

To him my tale I teach.

The history of Idealism has been very different. He who first formulated it, formulated it by the energies of the constructive reason in him; and formulated it well-nigh for ever. To its fundamental positions he worked his way slowly, sounding onward as through an unknown sea; availing himself of the diverse results of the earlier science of his race, but going far beyond anything of which it even had dreamed; and showing himself so pre-eminent in the power and insight of the labouring reason that since his day Idealism has never departed without profound loss from what is essential in his method and teaching, nor returned without receiving the touch and the inspiration of a new life.

In the first place, he fixed for ever the scientific point of departure of Idealism - the question how our knowledge is possible. Then, proceeding from that point of departure, he not only moved in the true direction in his attempt to comprehend the nature of reality and the meaning of our life, but moved so far in that true direction that the way was made easy to all who in later days could enter into his teaching as it really was. And another thing he did, in which his greatness as the founder of Idealism culminates. He stated his view of the world with a grace of temper, an elevation of soul, a prophetic and compelling passion, such as gave to his truth a double power and made it to the men of later ages an illumination and an austere allurement, a persuasion and a rebuke.

This Plato did; being one of those rare and most mighty spirits in whom the gifts and the insights that are given singly to other men, appear in combination, and in that combination take on a new and greater power, each contributing to the other, each enlightening the

1 The World and the Individual, First Series, p. 85. 
other, each deepening the other. First, there came to union in him the two great scientific currents in which the constructive thinking of the Greeks had hitherto run: the older metaphysic, Ionian or Italian, which sought to comprehend the universe as a universe; and the newer Socratic "way of ideas." In this combination each side found its true fulfilment in the other, so that, in the place of two brilliant but limited endeavours, there arose a single complete and solidly based and thoroughly luminous view of the world. Then, secondly, this synthesis itself was part of a still wider synthesis. On the one side, as the achievement just referred to indicates, he had in him the scientific mind. He had its intellectual disinterestedness, its passion after knowledge for its own sake, its instinct for looking straight upon facts and seeing them with clear eyes just as they are; he inherited, in a word, not simply the results of the previous scientific history of the Greeks, but also their scientific temper in the very perfection of those qualities which have made the Hellenic mind to all ages the pattern of the scientific mind. But he was possessed also, and to the very centre of his being, by the great practical passions: by the passion, moral and political, which seeks to shape life and the social organisation of life according to the good; and by the religious passion which apprehends, as the good, the ultimate principle of the universe, and thus sets the whole of man's life in the light of a heavenly vision, and directs all his energies to the works whose significance is eternal. And in him those things-that disinterested scientific temper, that passionate devotion to the realisation of the good, and that profound religiousness-were not warring tendencies; they were co-operating powers, each widening the scope and deepening the character of the others. And even this is not the limit of the union and co-operation in him of characters that ordinarily stand apart. Along with that scientific intellect, that moral and political and religious temper, there went the mind of the poet, and the capacities, both receptive and active, of the artist. And this side of his nature, once more,-in spite of the hostility that necessarily existed between him and those artists of his race who either were artists and nothing more, or else represented a reason earlier and unpurified by criticism-really worked together with the others. He was half poet; but in him poetic intuition was a form 


\section{PLATO AND THE FOUNDING OF IDEALISM}

of intelligence, rather than a rival of intelligence; and so the poet in him made him a greater, not a less, philosopher. He had the Ionian delight in beauty, and the Ionian command over the powers by which beauty is expressed; but he had also the earnestness of Lacedæmonno Dorian saw more clearly than he the need in human life of simplicity, of austere discipline, of that gravity of mind which lifts a man above luxury, above levity, above the habit of imitation. He had the unashamed Greek joy in the whole of existence; yet he was haunted by a vision of eternity which condemned alike the world that now is, and the mythology of his race, and the political order of his state. He had the Greek delight in life, the Greek instinct for the exercise and development of all the faculties of the soul, the catholic Greek sense for completeness and integrity of life; yet he knew that life can reach its true wholeness and integrity, not by leaving all its elements and interests upon a level, but only by recognising the good, and putting it in its place of supremacy, and arranging the whole of life as the manifold system of its realisation.

Such was the many-sided reason that dwelt in Plato and helped to make him the greatest figure in the long history of philosophy. But there is still something else. A metaphysician is a man who seeks to ascertain the true meaning of our experience. And the man who would do that, must have more than scientific temper and scientific ability, more than a wide mind and large capacities of reason; personally and vitally he must himself possess, on all its greater and constitutive sides, the experience into whose meaning he would inquire. For himself, and with directness and integrity of devotion, he must have walked in the ways of life and have taken his part in the world's work. And this requisite, too, was fulfilled in Plato. It was not only that he was man of science, artist, poet; not only that he sustained the part of friend and of teacher; but his heart was linked to the greater causes in the life of his people; he was a citizen drawn to the welfare of the Greek states with an intensity of earnestness that had in it the possibility, and at last the actuality, of tragic pain. He not only had a vision of perfection, but felt the call to realise it; to realise it not abstractly nor in dream, but concretely in the life of his dayin the education which lasts from birth till death, and in the order of 


\section{PLATO AND THE FOUNDING OF IDEALISM}

the state. He did not rest, as Windelband so finely points out, ${ }^{1}$ in his gaze upon the supersensuous world; he was not one of those saints of contemplation who "receive into themselves the great picture of existence and contemplate it in desireless peace." On the contrary, having brought from the eternal realm ideals for this, he took up "with passionate courage the struggle against the powers of the earth," and strove "with all the energies of his soul 'to improve and to convert' the world"; he was-and is-" the chief of all the spirits who exercise the energies of will." Such he was; and being such, there was no escape for him from the wrestle with the world, no standing apart from life, no remaining untouched by the storm of the times.

Thus, then, it was, that, while Spartan armies were going to and fro upon the soil of Attica, there was given to the world in Plato its most perfect example, not of philosophy only, but of the philosophic mind. He was a great man of science; but he was more; he was a mighty spirit, taking part in the struggle of man upon the earth, and bringing to that struggle its illumination with eternal light. And so, too, it was with his view of the world and of life; it shows the intellect working at its very highest power; but it is more than a work of the intellect. It is the passionate vision and creation of the entire human soul; a vision and creation in which the working of the greater passions - the passion for the state, the passion for righteousness, the passion for eternity - goes hand in hand with the highest energy of the disinterested intellect.

In attempting to understand this philosophy of Plato's as a body of doctrine-which involves not merely apprehending Plato's conclusions, but apprehending also the forces and tendencies that operated in him to shape them-we have three things to remember at the outset. First, Plato was an Idealist from the beginning; from the beginning the root of the matter was in him-there were no Kantian wanderings. But secondly, his Idealism was not complete from the beginning. The Idealism of his early and middle years had in it an incompleteness which it was one of the great labours of his later years to remedy;

1 At the close of his monograph on Plato (Frommanns Klassiker der Philosophie)-a brief but most admirable account, which ought to be translated into English. 


\section{PLATO AND THE FOUNDING OF IDEALISM}

and this later work gave to the whole structure of his philosophy at once greater depth, greater concreteness, and greater power. While thirdly, throughout Plato's whole life the forces that make, not for Idealism at all, but for Mysticism, acted upon him and found in his soul a great response.

These facts give us our plan of treatment. We are to consider an Idealist; but one whose Idealism (1) stands face to face with the great opponent of Idealism, (2) undergoes development from within. It will be wise to take the discussion in three steps: (1) To put down in summary form the conclusions which constitute the Idealism of his early and central years; and in doing this, to note what the internal incompleteness, just referred to, is. (2) Then to turn to the other side, and consider the operation upon Plato, and in Plato, of the influences that lead toward Mysticism. (3) Finally, to consider the later stage of his philosophy, in order to see $(\alpha)$ how far he has made good the incompleteness of his earlier Idealism, $(\beta)$ how far he has overcome, and how far yielded to, the influences leading him toward Mysticism. The two latter questions, it will be noted, do not stand apart; they are so closely interconnected as really to form one question; for the more clearly and fully Plato works out his Idealism, the more completely does he overcome the tendency toward Mysticism.

First, then, from the dialogues up to and including the Republic, we have to gather the ground-lines of the earlier Platonic Idealism, and to set these down in the form of a brief summary.

I.

What Plato saw to begin with was that our experience, our actual present life, in order to be what it is, must be a part in a system of reality greater than anything that now appears to us. He saw-saw with a clearness which simply startles an English student turning back to him from Locke or Bentham or the Mills-that there is in our present experience something which this present world cannot give; that there operates in our experience something which that experience itself as it now stands cannot account for. For our experience involves -one might almost say, is-the operation of conceptions which, both 
in perfection and in universality, go beyond the particular things and facts and events to which we apply them, and which we comprehend by means of them. They, it must be repeated, are not merely present in our experience; they are active and formative in it. They are in our minds not merely as something possessed, but as something operative; operative in the whole process of our thinking and knowing and doing. The straight line, for instance, the perfect circle, the perfect square, the perfectly equiangular triangle-these conceptions and the many similar ones which might be named, are, in the first place, actual possessions of our minds; but not that only; they are absolutely essential to even the most elementary process of knowing the world, and in that process are continuously operative and continuously regulative. Yet this present world does not give them; there are no straight lines or perfect circles in nature. And again, as we know nature, so also we regulate our conduct, by conceptions which the present world cannot give because it has them not to give. We seek perfect truth, and justice absolute, and the courage that is complete in wisdom; but where are these to be found existing upon the earth?

Here, then, in the elementary facts and the elementary form of our scientific and moral experience, is a great problem; and this problem is the point of departure for that great voyage of the intellect, to which Plato, by many interests, practical even more than speculative, was driven. As he advances from it, he works his way to a view of what a Greek would call the form-a modern, the constitution or eternal order-of the world; and to a corresponding view of the place, the development, the true function, of the soul as a part of that eternal world. This view we have now to consider; though, as we go on to set it down in orderly outline, we must remember that Plato himself nowhere presents it in one systematically articulated account; for it was his habit to develop now one, now another, of the many insights which enter into it; and to develop these single insights, moreover, by the method which best corresponds to the process and struggle and gathering light of actual experience-the dialectic method.

(1) First, then, Plato finds the form or constitution of the world to be essentially rational; this is the keynote of his Idealism, and of all Idealism. And unless Platonic Idealism, and all Idealism, is to be 
radically misapprehended, it must be clearly understood what it means to say that the world is rational in its constitution. It means something more than that each of the various things of the world has independently in itself a rational nature. It means that all the things of the world form one rational structure; form a system or process in which reason is realised. A number of forms, each rational in the sense of being apprehensible by reason, but simply existing side by side, would not constitute a rational order. A rational order implies some common purpose, some supreme principle, which is realised in and through the total system or structure. That principle gives to each part or element in the system its place and function, and by giving to it its place and function gives it its meaning and reality. So that the principle itself is at once the immanent law and constitutive energy -is even, in a sense, the essential reality - of the whole system. This is true of any system, of any whole made up of parts, which is to be called rational. Most of all is it true of that greatest of all "ordered and organised" wholes which is the real world. If the real world is an "ordered and organised whole," it is the realisation of some one supreme principle, which is at once the source and the immanent law of the structure of the world, and as such gives to each of those individual forms that make up the system of the world, its place, its function, its character, its reality. This principle realised and fulfilled in the structure of the world, Plato, in accordance with Greek usage, calls the Good. To him, that is to say, the order or constitution of the world consists in an hierarchy of rational forms-as he called them, Ideas-with the Idea of Good at the head of the hierarchy. Or, to put it in one word, the Good, as the source and law of all individual determinations, of all individual capacities and functions, and thus of all individual being, is the principle of reality. ${ }^{1}$

The steps in Plato's dialectic advance to this insight were of course many. One of them we shall have to deal with later, in considering the forces that broke in upon Plato's Idealism, and made it all the greater by making its battle harder. Here, however, a brief hint at the general course of this part of the Platonic argument will be

1 See Philosophical Lectures and Remains of Richard Lewis Nettleship, 1st ed., vol. II., pp. 217-237. 
sufficient. First, Plato saw that particular objects cannot stand alone. Their lack of an abiding form, their incessant change, their arising and their decay, show that they do not maintain their own being or exist in their own right. How, then, are they to be accounted for? At the very lowest-making your first concession to reason as small as you possibly can-you must go at least this far: that for each of the kinds, for each group of similar things, there must be some one abiding reality which fulfils itself through them and their changes. This abiding reality - to which Plato gave the name Idea-he, at the beginning of his work, tended to some extent to view as the common element that remained when the differences of the particulars were stripped away. But more and more he came to view it as an energetic principle, a creative power, which manifests itself in and through the things; so that instead of our being compelled to abstract from the differences to get it, it itself explains those differences. An Idea might perhaps be best defined for the modern mind by saying that each Idea, together with the things of which it is the principle, would form the object of a special science or special department of science. ${ }^{1}$ But with this “lowest possible concession" we cannot stop. For these constitutive principles of the various classes of existence cannot themselves stand apart or maintain their own being. They are not independent existences, standing side by side for ever; they must be conceived as forming one order, one universe. And what that means we have already seen; they are the media or organs through which one highest principle, one supreme creative energy, the Good, fulfils itself.

(2) The nature and operative principles of our minds correspond to the nature and operative principles of the world; thus it is that knowledge and intelligent conduct are possible to us. The soul which is man, is in organic union with those constitutive principles of the world (the Ideas) - or, if you will, is in organic possession of them. It brings them, or the potentiality of them, with it as its equipment for the business of life, as its principles of knowledge and its standards of conduct. This insight Plato delighted to set forth in myths of unexampled splendour. But the meaning of the myths is plain: the

1 E. Caird, Evolution of Theology in the Greek Philosophers, vol. I., p. 119 seq. 


\section{PLATO AND THE FOUNDING OF IDEALISM}

real world is rational; the soul is reason; therefore, science and intelligent conduct are alike possible.

(3) But that nature of the soul, and those its operative principles, are developed only gradually, in and by that process in which we at once apprehend reality and come to be ourselves. In knowing the world, the reason which is man, recognising the presence and operation of those eternal principles in the world, comes more and more into possession of them, and so comes more and more truly to be itself. This apprehension of the world, in its gradual development, passes from stage to stage of clearness; passes, as Plato at one point says, ${ }^{1}$ through three lower stages to find rest in a fourth. The first two of these ("conjecture" and "belief"), which represent the working of the intellect below the "scientific" level, we need not dwell upon here. But we must notice carefully the third, and the transition from it to the fourth. The third is what nowadays we should call the stage of the special sciences. Its defect is that each of its special divisions has its own point of view and its own point of departure; so that instead of seeing one universe in the light of one supreme principle, it almost has several universes. Or, as one may put it, it begins too far down the stream, and so, instead of seeing one stream, flowing from one fountainhead, it sees only several different currents. At this stage, then, knowledge is inaccurate in the sense of being abstract, " unfinished," incomplete. But in the fourth stage, knowledge becomes adequate in form to its object. For here knowledge directs itself to that supreme principle, only in the light of which can any particular thing whatever be truly understood; namely, to the Good, which the whole system and structure of the universe is intended to realise, and which, therefore, determines the place and function - that is to say, determines the reality-of each individual thing in the total system. So that the Good, just as it is the principle of being, is also the principle of knowledge. With regard both to the world and to our minds it is the principle of intelligence; for it is its activity, as giving to the things of the world definite determinations, definite places in the system, definite functions, that makes the things of the world intelligible; and it is 


\section{PLATO AND THE FOUNDING OF IDEALISM}

only through an apprehension of it that our minds can enter fully and finally into a true apprehension of things, and so become.truly and fully intelligent. Hence, too, knowledge of it (and conformity of character to it) is the ultimate object of education; and it is in the science which seeks to apprehend it, that education-for those who are able to go so far-culminates.

(4) To live in accordance with that true nature of the world is the true way of life for men. The world, as a system in which a supreme principle, the Good, realises itself (in measure and beauty and truth, as Plato said later), ${ }^{1}$ furnishes the pattern according to which man should organise his life. Indeed that statement is too weak; for the world is the whole in which man lives; so that the Good which is the organising principle of its structure and order, should be the organising principle for his life. That is to say, the Good (that which the world exists to realise) is more than a pattern for man; it is that to which men should directly devote themselves and seek to realise. So that the Good, as it is the principle of being, and the principle of intelligence, is also the moral end for man. Morality means to know the Good which is the eternal law of the world, and to make it the supreme principle of one's own life. But further: men cannot realise the Good as solitary individuals. They must become

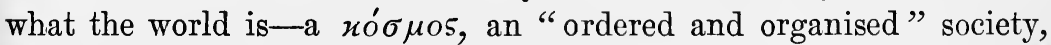
a state. The state, then, is a human institute for the realisation of the Good. In accordance with that purpose and no other, the state is to frame its constitution, to train its citizens, to educate its legislators and statesmen;-is even to limit its own size, so that the individual citizen shall not be prevented from participating in the whole of its life. And if a man is compelled to live in a state whose constitution is evil or imperfect, let him organise his life so far as he can in accordance with the order of the city whose "pattern is laid up in heaven " $; 2$ it is the model for all cities, and the only model for the man whose earthly city has an evil constitution; and, after death, it will receive those who have been faithful to its laws. ${ }^{3}$

1 Philebus, especially 64-67.

2 Republic, 592.

3 It is interesting to note how men's thoughts answer one another across the ages. Plato saw that our experience, in order to be what it now is, must be part of a reality 


\section{PLATO AND THE FOUNDING OF IDEALISM}

The foregoing statement is un-Platonic in form, but represents fairly, in terms of modern thought, the essential principles that had shaped themselves in Plato's mind by the time he reached middle life. If it were permissible to select any one Platonic statement as the most pointed expression of those principles, and of the view of the world which they constitute, it would be the comparison, in the Republic, of the Idea of Good to the sun. The sun is to visible things the source both of their being and of their visibility. Of their being, for he makes them what they are; he is "the author of generation and nourishment and growth, though he himself is not generation." And of their visibility, for he gives to them their capacity of being seen and to the eye its capacity of seeing them. In the same way the Idea of Good gives to all things their real and essential existence; and, by precisely the same creative or constitutive activity, it gives to them that rational character-that place in a rational system fulfilling a rational end-which is their knowableness. ${ }^{1}$ The Idea of Good, in one word, is the principle of being, the principle of knowledge, and, as is added a little later, ${ }^{2}$ the principle of conduct.

\section{II.}

Such a view concerning the form or constitution of the world, and concerning the place and development and function of the soul in the world, is Idealism. And yet, in anything that can be called a study of Plato, this view must stand as the beginning rather than as the end. In philosophy, battles easily won are usually either not worth the winning, or are won so easily because of the hard labour of earlier men. And Plato's battle was far from easily won. He fought over nearly the whole ground of philosophy; that it is, in fact, which makes him at once so deeply instructive and so infinitely suggestive.

greater than anything that now appears to us; and so he marked out a course of lifelong education to lead us to the knowledge of that eternal reality, and called us to "philosophy," i.e., to a life of political and speculative activities in which we more and more make our society and ourselves at one with that reality. It is preeisely the same insight-or one aspect of it-that Professor Royee (The World and the Individual, First Series, p. 56) puts into the terse statement: "We live looking for the whole of our meaning. And this looking constitutes the process called thinking." 


\section{PLATO AND THE FOUNDING OF IDEALISM}

First, as was pointed out above, in the Idealism whose main positions have just been set down, there is a certain incompleteness. It is incomplete in the conception of its highest principle. For it viewed the Idea of Good as a constitutive and organising principle. The' Good exercises a creative energy; it is the source and home, the ordering power, the principle of unity, of the world. But that at once raises the question: In order to be such a principle, must not the Good be conceived as something more than simply the Good? If it is truly to be regarded as performing the supreme function of constituting and ordering the world, must it not be taken up into some still higher principle? Must it not, that is to say, be regarded as living and active spirit; so that the world would be viewed as constituted by an eternal spirit who is the subject of the world, whose Ideas are the regulative forms of the world, and the supreme law of whose activity is the Good?

To this problem Plato came in his later work. In that work he made, indeed, what looks like a fresh start; for he came at the problem from a somewhat different angle of approach, and used a different terminology. But really it is the same problem; and really, therefore, the advance is continuous. ${ }^{1}$ But before we go on to consider that advance, there is another matter to be dealt with. For, as also was noted above, throughout the whole of Plato's life, the forces that lead men, not to Idealism at all, but to Mysticism, worked upon him; and upon that many-sided mind, sensitive as it was to all spiritual influences, they could not be without effect. To these we must now turn; and in dealing with them we have to consider (A) in what form they acted upon Plato; (B) what influence they had, whether in breaking the unity and preventing the completeness of his Idealism, or in setting another view alongside of it. Then, finally, we can come to that thinking of his later years in which, so far as was possible to him, he dealt with both the great problems that beset him; and, by a certain development of his thought, at once put the keystone into the arch of his Idealism, and overeame-though to the end only in partthe mystic tendency.

1 One of the reasons for believing-what here is taken forgranted-that the Parmenides (with the allied dialogues), is a genuine Platonic writing. 


\section{PLATO AND THE FOUNDING OF IDEALISM}

(A) First, then, the influences that make for Mysticism fall into two great classes. For Mysticism has a twofold aspect. It is a type of speculative thought; but it is also a movement of the practical spirit. It is an intellectual conclusion; but usually it is also a conception of religion and a way of life.

(1) So that we have to distinguish, first, the more purely intellectual ways along which men are led to Mysticism. The general tendency manifest in these may be seen by considering the situation in which the philosophic intellect stands at the beginning of its work. For what sets it upon its work is the insight that experience can be what it now is only upon the supposition that reality goes far beyond the appearances which from moment to moment make up the fleeting content of experience. And the work to which this insight calls philosophy is, of course, the attempt to reach a form of consciousness more adequate than the everyday consciousness to the apprehension of that reality. But precisely in this beginning and in this point of departure there lies for the intellect a great danger. It should remember that the reality to which it is attempting to make its way, is sought as the explanation and the illumination of the experience from which it first set out. Or, in technical terms, it should remember that the desired universal and the present particulars are in organic connexion; that the noumenal order does not stand separate from time and from phenomena, but rather is the phenomenal order truly understood; else the one is no explanation of the other. But this very thing the intellect is tempted, not to say driven, to forget; and that by the nature of the situation itself. For what the-mind is seeking to do is to pass from an experience of appearances to a consciousness of reality; and what stands out in the foreground, and is acutely felt, is, of course, not the likeness of the two, but their difference. The reality-in its character surely it is that which the appearances are not. They come and go, arise and decay; it abides for ever, and is always itself. They are chained to eye and ear; it, for its existence and perfection, depends upon no perishing organs of flesh. Thus the tendency arises to separate the two: what they are, it is not; what it is, they are not. And the two being separated, the way of the soul is 


\section{PLATO AND THE FOUNDING OF IDEALISM}

plain; in the vision of the perfect and eternal reality, it must forget, or resist, or despise, the present world.

This tendency takes many forms and operates in many degrees of power. A number of the purer cases of it we have already considered in dealing with Spinoza. ${ }^{1}$ It did its work almost completely, for instance, when, through generations of forgotten men, the Hindu mind, moving under a burden of sad experience, sought to reach the one fundamental reality by saying Nêti, Nêti-It is not so, it is not so - to every particular form of god or goddess and to every particular natural determination; and thus accomplished the vast march of thought from Veda to Vedânta. Or again, it swept in perfect intellectual clearness, and with one arrow-like flight, to its goal, when Parmenides sharply and abruptly set over against the world of the senses, a reality which purely and absolutely is, and is not flawed or limited or contaminated by any "is not." These thoroughgoing cases, as a rule, occur either at the beginning of a great civilisation, or in its decline: at the beginning, when the pioneers of thought, by sheer force of speculative daring, carry one-sided methods through to their conclusion; in the decline, when men turn away from the evil world, and the religious influences which we are to consider in a moment work victoriously upon them. But the logic of Mysticism is also able to secure a footing in the middle periods, when the great constructive and comprehensive minds are at work. In a different way, however; usually as a tendency concealed in some method which is accepted without question, but whose final significance is not perceived. In such a method Mysticism often lies implicit, until at last some intellect, fearless in its logic, but working in the service of the religious instinct, carries the method relentlessly to its conclusion, and shows reality to men as that with which they can enter into union only by renouncing the world and all the normal forms of experience.

For our present purpose, one such method is specially important. It is, indeed, simply a particular case of the general situation described a moment ago. The facts and events of the world, as they are given to us in our everyday consciousness, cannot stand alone. If we would really understand them, we must go to something wider than them-

1 Supra, pp. 126-150. 


\section{PLATO AND THE FOUNDING OF IDEALISM}

selves; to the laws or principles which govern them, which hold them together and make them and their changes one connected and systematic world. In the language of philosophy, we must go to their universals. But how are we to conceive those universals? If we remembered that we seek the universal as an explanation of the particular, we should see that the universals must be active principles of synthesis-active and concrete principles which hold things together into one world, and by giving to each particular its place in the world give it its reality. The universals, that is to say, would be conceived as at once explaining and containing both the particulars and their differences and their relations; would be conceived as at once the source and the home alike of the particulars, and of the relations which link them together into one system, and of the differences which mark their individuality. And the highest universal would be the most concrete of all, being the source and home of the whole order of the world, of all the individuals in it, and of all the relations and differences which make them individuals and yet link them together by eternal laws in the one system of the world. But at the very beginning of the search for universals there is something which frequently leads us to forget all this. For the universal is something which is common to all the members of a class; they all share in it, and their sharing in it is the source of their reality. But how are we to get at something which is common to all the diverse members of a class? Surely nothing can be easier-simply strip away the differences and retain what is left. It is very natural thus to take for granted that since the universal is a form common to all the members of a class, the way to reach it must be by abstracting from the differences of those members. But natural as it is to drift into such a method, it puts you, as soon as you adopt it, into the grip of the logic of denial. For as you ascend from stage to stage, stripping away the differences from particular things and specific conceptions, your universals become more and more abstract, until at last you reach the end with an ineffable One which is beyond all natural determinations and all forms of reason; and union with which, whether speculative or practical, ${ }^{1}$ is therefore to be attained

1 Whether speculative or practical:-To the thoroughgoing Mystic, it should be remembered, these are really one. 


\section{PLATO AND THE FOUNDING OF IDEALISM}

only in some experience which transcends all forms of reason and all ordinary activities of the rational spirit which is man. Thus it was, for instance, that mediæval Realism with its strong tendency to ascend to the universal by the method of abstraction, led the way to Mysticism. When its method was taken up by men of deep inward religion and of an unflinching logic which not even canons and decretals could bind, that which was left to them at the end, after they had abstracted from the last differences-from the distinction between God the omniscient knower, and the world, ideal or temporal, which He constitutes and knows; and from the distinction between the persons of the Trinity-was that ultimate Godhead, that "still wilderness" which "never did look upon deed" and "where never was seen difference, neither Father, nor Son, nor Holy Ghost."' The same tendency, again, was manifest when Spinoza, on one side of his thinking, carried to the last conclusion a method and a principle which, coming from Descartes, seemed new, but in truth were as old as mediæval Realism, and in the hands of a rigorous logician had in them the same potentiality of Mysticism. Or, to take an instance which lies at our very doors, the abstract tendency is present in the later thinking of Kant, and is in constant strife with that concrete or synthetic method which is Kant's proper contribution to modern philosophy; a strife so continuous that without reference to it, as the Master of Balliol in almost every chapter of his great exposition has to remind us, scarcely any leading point in Kant's critical philosophy can be understood.'

1 See the paper on Meister Eckhart in Professor Royce's Studies of Good and Evil; especially pp. 276-282, and the words of Schwester Katrei as given on p. 297.

2 Indeed, it might almost be said that in man's effort to come to reality, Mysticism may arise from $a n y$ important error, from any important misuse of categories, provided (1) that the method employed be that of the purely analytic logic which carries a beginning rigorously to the conclusion, allowing no opportunity for turning back upon it to criticise or reconstitute it; (2) that the men be too completely possessed by intellectual gravity or by religious passion to rest in the philosophic scepticism which would be the outcome of the mere logic of the situation. To take a most unpromising instance-a case where the beginning augurs anything but a mystic close-if a man, deeply religious but at the same time keenly logical, were with implicit confidence to accept as his point of departure almost any book of the traditional English or Scottish school of philosophy, he would almost certainly become a Mystic; would almost certainly come to deny the world given to his present intelligence in the name of a reality not apprehensible by intelligence, and to seek desperately for some way of union with that reality. Indeed, if $\mathrm{Mr}$. Herbert Spencer, retaining his philosophy, had been predominantly a man of religion rather than predominantly a man of science, he would have been a Mystic.-But the most remarkable of recent 


\section{PLATO AND THE FOUNDING OF IDEALISM}

In Plato both that general and this special form of the intellectual movement toward Mysticism are found. The explanation of our present world and of our experience in it, lies for him in a world of perfect and eternal realities, the Ideas, which are at once rational forms and rational energies. And, of course, he knew that the explanation and the thing explained must be in organic union: that world, he knew, must be the truth of this world; this world, truly known, must be a factor or element in the life of that, and a manifestation of its nature. But, like all high and clear spirits who are acutely sensitive to the evil and the imperfection of this world, Plato is tempted to let his soul dwell in that world, forgetting this, or despising it, or renouncing it, as a thing only of some secondary reality which in the presence of true reality stands condemned for ever. And to this temptation to set the two worlds apart, the one as shadow, the other as reality, he continually yields. Perhaps his keenest feeling is the feeling of the difference between the real world and this present world of the senses-this, inconstant, fleeting, full of change and decay; that, with its unchanging perfections of reason. And this feeling, as we are to see in a moment, was intensified by the form which the religious passion often took in him; and by the way in which he suffered from the resistance of his Greek world to that ideal which represents the demand of the real world upon present society. So that, in his central period, Plato, like Erigena, like Aquinas, like Spinoza, like Kant-like his own pupil, Aristotle-is torn between the synthetic and the abstract movements of thought, between theologia affirmativa and theologia negativa. It is true that the conflict of these tendencies assumed a very different form in him from that which it assumed in Erigena or Aquinas, in Spinoza or Kant. It is true also that the yielding to the negative tendency is less in him than in any of the others just named $;^{1}$ true that the promise and the power of that thoroughgoing Idealism to which he was later to come is already in

intellectual approaches to Mysticism comes from a very different direction. It is (if I may venture so daring a statement) that found in the keenest of modern English dialecticians, a man of thought to whom we are all deeply indebted, Mr. F. H. Bradley. The cause of it, which lies in his treatment of some of the higher categories, is most interesting but cannot be discussed here.

1 Even than in Aristotle, See the discussion in Caird, Evolution of Theology in the Greek Philosophers, vol. I., especially pp. $285,286$. 
the dialogues of the central period. But none the less the strife is there. And in the special form mentioned an instant ago-i.e., in advancing from particulars to class-conceptions-the strife is also there. In the earlier thinking of Plato there is a wavering between two views of the relation of a universal to the particulars grouped under it; the two views, as one may say, are present in solution. The one, regarding the universal as the common element in different individuals, tends to seek it by abstraction, by leaving aside the differences of those individuals, and to give it an existence independent and separate; making it, to use an expression of the later Plato, like a sail drawn over the individual members of the class. ${ }^{1}$ The other regards it as a synthetic principle, manifesting itself through differences, and therefore both explaining and containing those differences. And as far as the former prevails, it makes possible, in the way already indicated, the logic of Mysticism.

(2) But, as we have seen, there is another order of influences making for Mysticism - the practical or religious; and it is only when these co-operate with the first that Mysticism in the completeness of its type arises. The nature of these may be indicated in this way.-To the religious instinct and passion, in its higher development, two directions of movement are possible; and thus in man's effort after God two tendencies have arisen. These are seldom found in purity of type, ordinary religious life usually containing both, though approximating sometimes to the one, sometimes to the other. Of these tendencies the one which commonly is the earlier to prevail, whether in the individual or in any deeply religious age, is dominated by the sense of the sharp contrast between the world and God; the world as evil, God as altogether good; or the world as nothingness and vanity, God as all in all. But the later and more thoughtful tendency sees that Manichæism in any form shatters religion itself; that the religious life in its every step implies an organic connexion between God and the world; God being led by the goodness of His nature to - impart Himself; the world being a process wherein, by that increasing impartation of Himself, He realises an eternal purpose which itself arises from His nature and is the expression of it. The religion

1 Parmenides, 131 BC. 


\section{PLATO AND THE FOUNDING OF IDEALISM}

of this latter type is the wider and the profounder; in a certain very important sense, it is really the more religious. But the religion of the former kind is usually the more intense and overmastering. It makes ascetics and warriors; and it has in it at least the beginning of Mysticism. For on the one hand it presupposes an eternal reality and the possibility that man can become at one with it; and it makes the quest after such union the supreme business of life. But on the other hand it is convinced that upon no such ways as those of the present world, through no such energies as those of man's natural soul, is that union to be attained.

Now, Plato was a man profoundly religious. And both his native character and the circumstances of his life made it inevitable that at least occasionally, under special stress of the world's evil or the world's tragedy, the religious temper in him should assume the first rather than the second of the two forms just distinguished. For in him was the grave Dorian austerity which can lift men with indignant scorn above the allurements of the world; and the hunger after eternity and after perfection, which in this world, or in any world made after the fashion of this, can find no rest; and that inborn purity of mind, observable in fine and high spirits, which turns instinctively away from evil and seeks its home with a reality in which evil and the trouble of evil have no place. And his outer life was fitted to develop the world-denying instincts within. Only too well he knew the saddening of the soul which comes to men who enter upon life with high devotion to the welfare of their society and to the great causes in which that welfare consists, and find the world to be a body of death, immovable by that passion, unresponsive to those purposes. It was not merely that the men of Athens, the best of them as well as the worst, had slain his master. But in him a high ethical and political passion, the passion of the reformer who has gazed upon heavenly perfection and seeks to bring it to the ways of earthly society, broke in vain against the life of his day; broke in vain against the pride of the elder Dionysius; in vain against the life of Athens, where the citizens were no longer men of Marathon, but loved comfort and cleverness and unstable change more than righteousness; in vain against the general political condition of the Greek world in the period 


\section{PLATO AND THE FOUNDING OF IDEALISM}

that runs from the day of the Thirty to the coming of the Macedonian. And so it came to pass that through the whole course of Plato's life there ran that same tragedy of passion and of hope which filled the early years of Wordsworth. The passion of the prophet and of the reformer shattered itself into despair against the circumstances of the age, and against the brute power with which political inefficiency and political corruption can maintain themselves against high ideals and high character. ${ }^{1}$

(B) Thus, then, the influences that lead toward the doctrine and life of the Mystics, acted upon the founder himself of Idealism. What response, we must next ask, did they call forth ? what result had they in Plato's view of reality and of the way of life?

One thing is clear to begin with. They have influenced very deeply the tone and expression of the Platonic philosophy. It presents itself to its students as a many-coloured web shot through and through with mystic motives. Not only toward what we commonly call the things of the world, but also toward many even of the virtues in their ordinary exercise, and toward the opinion which is at least a potentiality of knowledge, and toward many of the greater literary and artistic forms, Plato takes up frequently the true Mystic's attitude of pity and renunciation and rebuke. And he has the Mystic's strange and compelling glory of speech, the power mingled of prophecy and poetry, which, logically or illogically, has fallen so often to the lot of those who use speech only for winning men to the silent life. In calling men to the renunciation of the world, to the practice of death, his words take on the tint of Mysticism, just as sometimes, on evenings late in autumn, the sky that bent over the work of the day ceases to be a thing of this world, and with stern magnificence and yet with beauty unutterable testifies against the weariness and the ambitions of the earth, and against the men who in these things lose themselves.

Nevertheless, the outcome in Plato was not Mysticism. It was not to be that among men of Greek speech the great argument which Parmenides had left a thing purely intellectual should advance to "do the full work of a philosophy" as an ethic and a religion. Though Plato

1 See the excellent statement in Windelband, Platon, especially in the first chapter and in the concluding pages. 


\section{PLATO AND THE FOUNDING OF IDEALISM}

revered Parmenides, and though of all the Hellenes he was the most fitted in character and experience to respond to the appeal of Mysticism, yet the very fact that he was a Hellene made it impossible that it should be his vocation to lift the Parmenidean view of reality into a wisdom for the guidance of life, and to give to that wisdom its language of irresistible persuasion. The Greek loyalty to reason and the energies of reason; the Greek love of definite and specific form; the Greek belief that such form is truly and essentially characteristic of reality:- these held the field. He was not won away from his view that the forms and energies which constitute reality are forms and energies of reason; and that this rationality of the real means that it has one supreme and organising principle, the Good, without devotion to which reason is not reason. And holding to this, he is not a Mystic. For though he may sometimes speak of the present world with the voice of a Mystic, yet there remains a difference which is essential. The relation between Plato when he goes farthest toward Mysticism, and the thoroughgoing Mystic, might be stated in this way.-Both believe that there is a reality untroubled by change or evil or decay. Both believe that in union with that reality lies the welfare and blessedness of the soul. Both believe that it is beyond all reach of sense-perception. But the Mystic goes on to add that it lies just as much beyond all forms of reason as it does beyond sense-perception, so that if you woùld apprehend it, and make it your own, and become at one with it, it must be in an immediacy of experience which transcends reason, transcends all ordinary forms of cognitive and moral experience. While Plato urges, on the contrary, that the truly real is the very perfection of reason, the very perfection of all rational form and rational energy, and that it is by perfecting the reason within youreason in the greater sense of the word, not the mere logical intellectthat you draw near to it. With the Mystic, to put it in a word, the negatives directed against the present world, and against the life that men live if they walk in its ways, are uttered in the name of a reality above reason; with Plato those same negatives are uttered in the name of a reality which is the completeness of reason.

So that Plato, even though you can learn a great deal of practical Mysticism from him if you have the right kind of soul, remains an 


\section{PLATO AND THE FOUNDING OF IDEALISM}

Idealist. Yet the influences which we have been considering were by no means without their effect. They were not able to make the earlier Plato a Mystic. But they were able to do something: they were able to determine the type of his Idealism. They caused it to be of that modified type which was sketched on an earlier page, ${ }^{1}$ under the name of Abstract Idealism: that which regards the genuine reality and the true home of the soul as a world of pure reason (in that larger sense of the word already indicated), from which this present world of the senses is separated as a realm of merely secondary reality; so that the union of the soul with the genuine reality is to be won, its citizenship in that world accomplished, only by a life in which sense-experience is not an integral element subserving the interests of the spirit, but is regarded rather as an alien atmosphere to be escaped from.

In setting down the broad outlines of the earlier Platonic Idealism we noted as a matter of fact, and without considering the explanation, that there was an incompleteness in its conception of its highest principle. What we have now seen might almost be put in this way: that corresponding to that incompleteness at the top, there is an incompleteness at the bottom; the world given to the senses is not clearly and unwaveringly viewed as a manifestation of the highest principle, and as a factor in its realisation of its purpose.

This, however, we must understand somewhat more fully. And that can best be done by returning to that summary outline, and considering in what way the negative tendency, when it comes to the front, is able to modify each of the four positions there indicated.

(1) First, then, Plato often speaks as if the system of Ideas were not so much the form, or order, or constitution, of the one universe which we know and of which our present experience is an integral part; but were rather a universe existing by itself and complete in itself-the real universe; and this sensible and temporal process in which we now live, a system having only a secondary reality. So that, in this aspect of Plato's thought, we approach to a theory of two worlds: one of absolutely pure reason and complete righteousness, where without hindrance the Good perfectly realises itself; the other an imperfect realm of sense and time. And of this lower world Plato

1 Supra, p. 12. 


\section{PLATO AND THE FOUNDING OF IDEALISM}

speaks in varying tones. Sometimes he makes it a shadow, or a hindrance, or a prison. From it the good man seeks to escape, philosophy as a "practice of death" being his way of deliverance. At other times he views it as in some sense organically connected with the world of Ideas. The things of this world have some share, by participation or imitation or however it be, in the nature of the Ideas; so that in this world, even in the forms and activities of the "unexamined life," some fulfilment is possible of that Idea which is the life-giving sun of the real world-the Good.

(2) But when Plato has to deal explicitly with the question of the possibility of knowledge, what will he do with his tendency toward a two-world theory? For in knowledge the two worlds are together; particular and universal are in organic connexion. Knowledge is really an interpreting of particulars in the light of their universals. Or, if you have failed to see that, and regard knowledge as having to do only with universals - so that the process of gaining knowledge is a passing out of particulars to universals-still the very fact that you can pass from the one to the other shows that the two are in connexion. What Plato does is very remarkable. He maintains-to explain the possibility of knowledge he must maintain-his belief in the correspondence of the nature and principles of our minds to the nature and principles of reality, and in the consequent capacity of our minds to form class-conceptions which represent to us the Ideas. But when his sense of the gulf between the two worlds is strong upon him, he expresses that belief not scientifically, but prophetically, in myths and parables that for blended charm and majesty stand unequalled in literature. (The souls of men-so in these he teaches-pre-existed, and in their pre-existence gained some glimpse, fuller or narrower, of the Ideas. That vision, when they fell to the earth, they retained in a sort of latent memory; and so bring with them to their present life the potentiality of true knowledge. Under the stimulus of the things of this world, which imitate the Ideas or share somehow in their nature, that potentiality is realised, or may be realised; the ancient vision, called from its latency into clear consciousness, becomes what we call knowledge or science, but what truly is Reminiscence. It will 


\section{PLATO AND THE FOUNDING OF IDEALISM}

be observed what this really means. It means that, even when Plato is using the speech of Abstract Idealism, the root of Concrete Idealism is in him. For while the form of language used in such a myth as that of the Phaedrus sets the two worlds apart, its essential meaning joins them together.

(3) Under the influence of the separation of universal and particular, of Idea and phenomenon, the "stages of knowledge" come to be represented, not so much as stages in a development in which we pass from the vague and inadequate to the clearer and more adequate, from the abstract to the concrete, in one word, from the particulars in isolation to the particulars seen in the light of the Idea of Good as elements or factors in its realisation; but rather as different kinds of insight relating to different orders of objects. Knowledge and opinion are different faculties and have to do with different kinds of subject-matter. The sphere of knowledge is being; but the sphere of opinion is that mixture of being with nonbeing (i.e., of the Idea with empty space) which is the present world. The one is absolute and infallible, as having grasped the supreme principle of the real world and seeing everything in its light. But the other is relative and erring, tossing about in a region which is halfway between pure being and pure non-being. ${ }^{1}$ He who has failed to grasp the Idea of Good which is the supreme principle of all reality and therefore the master-light of all vision of reality-can we allow his "opinion" to be a genuine stage on the way to knowledge? Rather we must say of him "that he knows neither the essence of good, nor any other good thing; and that any phantom of it, which he may chance to apprehend, is the fruit of opinion and not of science; and that he dreams and sleeps away his present life, and never wakes on this side of that future world, in which he is doomed to sleep for ever."

(4) So far as the two-world theory prevails, the rule of conduct,

1 Republic, 476-480. Cf. Symposium, 202A, and even Timaeus, 51D, 52.

2 Republic, 534C, tr. Davies and Vaughan. Compare the treatment of "right opinion" in the Meno (97-100), where the tone is gentler (though possibly with a touch of irony-e.g., in the reference to that right opinion of statesmen which is in politics what divination is in religion-" for diviners and also prophets say many things truly, but they know not what they say") but the radical opposition itself is by no means obscured or given up. 


\section{PLATO AND THE FOUNDING OF IDEALISM}

"live in accordance with the true nature of the world," comes to mean: Rise to citizenship in the real world, and in order to do so separate yourself from the life and the ways of this present world. Positively, that is to say, the good man is called to a life not of this world. While, negatively, it is held that the Good cannot be realised under the ordinary forms of our present experience, so far as that experience is one of time and sense; so that "demotic virtue," instead of being viewed as a genuine though inadequate stage in the realisation of the Good, is regarded as a phantom of virtue calling for downright condemnation. Both these sides of the abstract tendency come frequently to expression in Plato; but the place where they secure their most continuous and impressive statement is-with singular appropriateness-in the Phaedo. The man of philosophic mind "is always pursuing death and dying," and "has had the desire of death all his life long." But what is "the nature of that death"? It is that " release of the soul from the body" which enables the soul "to exist in herself." 1 For the body is a hinderer in the acquirement of knowledge. The senses which it brings to the soul are "inaccurate witnesses."' So that the soul, if she attempt "to consider anything in company with the body" is "obviously deceived"; and if she is to gain a revelation of true existence, must gain it in that thought in which "the mind is gathered into herself, and none of these things trouble her,--neither sights nor sounds nor pain nor any pleasure," in which "she takes leave of the body and has as little as possible to do with it," in which "she has no bodily sense or desire, but is aspiring after true being," in which she is free from all the troubles and evils of the bodily life, hunger and disease, "loves, and lusts, and fears, and fancies of all kinds, and endless foolery," "wars and fightings and factions." 3 So long as the soul uses the body as an instrument of perception (i.e., uses the senses), she is " dragged by the body into the region of the changeable, and wanders and is confused; the world spins round her, and she is like a drunkard, when she touches change. . . But when returning into herself she reflects, then

$164 \triangle \mathrm{ABC}$.

$265 \mathrm{~A}$.

365,66 . 


\section{PLATO AND THE FOUNDING OF IDEALISM}

she passes into the other world, the region of purity, and eternity, and immortality, and unchangeableness, which are her kindred, and with them she ever lives, when she is by herself and is not let or hindered; then she ceases from her erring ways, and being in communion with the unchanging, is unchanging." 1 It is at this existence of the soul in herself alone, in which "the soul in herself" beholds " the realities of things," that philosophy (in Plato's sense of the word) aims while the soul is still cumbered with the body. "The lovers of knowledge," says Socrates, "are conscious that the soul was simply fastened and glued to the body-until philosophy received her, she could only view real existence through the bars of a prison, not in and through herself; she was wallowing in the mire of every sort of ignorance, and by reason of lust had become the principal accomplice in her own captivity. This was her original state; and then, as I was saying, and as the lovers of knowledge are well aware, philosophy, seeing how terrible was her confinement, of which she was to herself the cause, received and gently comforted her and sought to release her, pointing out that the eye and the ear and the other senses are full of deception, and persuading her to retire from them, and abstain from all but the necessary use of them, and be gathered up and collected into herself, bidding her trust in herself and her own pure apprehension of pure existence, and to mistrust whatever comes to her through other channels and is subject to variation; for such things are visible and tangible, but what she sees in her own nature is intelligible and invisible. And the soul of the true philosopher thinks that she ought not to resist this deliverance, and therefore abstains from pleasures and desires and pains and fears, as far as she is able;"-delivering herself thus from the dominion of pleasure and pain, because "each pleasure and pain is a sort of nail which nails and rivets the soul to the body, until she becomes like the body, and believes that to be true which the body affirms to be true; and from agreeing with the body and having the same delights she is obliged to have the same habits and haunts, and is not likely ever to be pure at her departure to the world below, but is always infected by the body; and so she sinks into another body, and there germinates and grows, and has, therefore, no 


\section{PLATO AND THE FOUNDING OF IDEALISM}

part in the communion of the divine and pure and simple."1 So that philosophy, while we remain upon the earth, is a study and practice of death. But that the long purification and deliverance may be consummated, the body must be more than subdued; it must die, so that the soul may take up her dwelling altogether " in her own place alone." And hence, when the day of death comes, the true lover of wisdom will depart with joy, having " a firm conviction that there, and there only, he can find wisdom in her purity.", The soul "which is pure at departing, and draws after her no bodily taint, having never voluntarily during life had connexion with the body, which she is ever avoiding, herself gathered into herself ;"-such a soul cannot "at her departure from the body be scattered and blown away by the winds and be nowhere and nothing," but "herself invisible, departs to the invisible world-to the divine and immortal and rational: thither arriving, she is secure of bliss and is released from the error and folly of men, their fears and wild passions and all other human ills, and for ever dwells, as they say of the initiated, in company with the gods."3 While, on the other hand, the virtues which do not measure up to this level-the "demotic" virtues, the virtues of men who live in the sphere of sense and time, and are busy with the matters of this phantom world, and are unguided by the vision of that Good which is the source and form of all virtue:- these cannot properly be called virtues at all. The courage of such men is but another form of fear. They face one evil because they fear a greater; they are courageous because they are cowards. Similarly their utilitarian temperance is intemperance; they abstain from one pleasure because they desire another, overcoming pleasure in one form because they themselves are overcome by it in some other form." They do not know that "the exchange of one fear or pleasure or pain for another fear or pleasure or pain, and of the greater for the less, as if they were coins, is not the exchange of virtue." Wisdom-i.e., the apprehension of the Idea of Good and the viewing of things in its light-is the "one true coin for which all things ought to be exchanged"; and the virtue which is

$182 \mathrm{E}, 83$.

$268 \mathrm{~B}$.

$380 \mathrm{E}, 84 \mathrm{~B}, 81 \mathrm{~A}$.

$468 \mathrm{DE}$.

569 A. 


\section{PLATO AND THE FOUNDING OF IDEALISM}

made up of the goods of the earth, severed from wisdom and exchanged with one another, "is a shadow of virtue only, nor is there any freedom or health or truth in her."1

To sum up, then, what we have so far seen, we must say that the two tendencies which have been the main currents in the greater history of philosophy and of religion, are both present in Plato: the synthetic, which in philosophy gives rise to what we have called Concrete Idealism; and the abstract or negative, whose partial triumph gives rise to Abstract Idealism, but whose complete domination in a profoundly religious mind is the source of Mysticism. But we must also note the relation in Plato of these two tendencies. The tragedy of the world lay close at his heart; and the most impressive thing in all his writing is his prophesying against the world. But in spite of that, we must make no mistake about the fact that even in his earlier and middle years his deepest loyalty is with the synthetic tendency. True, its victory is in this period never complete. Again and again Plato draws the line sharp and hard between science and opinion, between demotic morality and true virtue, between the soul in the body and the soul freed from the body, between the real world and the cavern of our sense-experience; again and again with sad earnestness he exhorts men to practise death that they may truly live, and to fly from the world to God. But with all this, the deepest impulse of his philosophy is toward an organic connexion of our present life, and of the system of things in which it is lived, with the ultimate principle of reality. This, of course, is a question of the final impression which the whole body of his writings in the periods in question makes upon the reader. But special reference may be made to two subjects which already have taken pre-eminent place in his thought: the state as the greatest of human institutions for the concrete realisation of the Good, by the bringing of men's lives out of confusion, out of self-willed individualism, into an order which reflects the order of eternal reality; and still more, ${ }^{2}$ education as that

$169 \mathrm{~B}$.

2 Still more:-because with regard to the state, the facts of the world have driven him partly to despair (Republic, 592); so that even in its culmination as a theory of the state, his Idealism is touched by the breath of the theologia negativa-touched by its breath, not 


\section{PLATO AND THE FOUNDING OF IDEALISM}

in which men, not by suppression of the normal energies and capacities of their nature, but by the development and discipline of these, are led throughout the whole of life in knowledge and in character toward the Good.

But Plato, lover of truth for its own sake, and master of that dialectic method which criticises its own conclusion, and brings to light the further problems implicit in it, and corrects or enlarges it until those problems are adequately solved, would have been something less than himself if he had left his philosophy in this strife of tendencies. Plato was a man to look his own problems in the face; and therefore the passage of years brought to his Idealism a steady growth in thoroughness, in self-consistency, in mastery of its materials. $\mathrm{He}$ felt that in some genuine sense everything which you cannot decisively reject as mere unreality, mere void nothingness, must be organically connected with the supreme principle of reality; indeed, that is the cardinal instinct of all philosophy, and its presence in Plato compelled him to face the problems that arose from his tendency to separate the world of pure reason and perfect goodness from the world of sensible and temporal experience. With these problems he dealt in his later period, which might almost be described by saying that in it the conflict between the two types of Idealism comes explicitly forward, and is settled, so far as was possible to him, in favour of the Concrete.

\section{III.}

But this brings us to the third step of our work. We have to consider that later thought of Plato in which he apparently makes a new start, but really carries directly forward the development of his Idealism. In approaching this it is necessary to have in mind the exact situation in which at the beginning of that later thought he finds himself. Hence it is advisable to note again, first, the problems which remain for him from his earlier thinking; secondly, the positive

possessed by it, for the cause of his despair about the state lies in the folly of men, not in any incommunicability of the Good. (Compare as a striking, though somewhat poetical, instance of a feeling for the organic connexion of civil society with the "pattern laid up in heaven," the assertion placed in the mouth of Socrates in the Crito of the kinship of the Athenian laws with those of the world below.) 


\section{PLATO AND THE FOUNDING OF IDEALISM}

insight which he carries forward with him and upon which any advance in solving those problems must be based. The problems, as already we have seen, are two. (1) There is a problem connected with the conception of the highest principle. If the Good is to be regarded as the creative energy and organising principle of the universe, must it not be conceived as something more than simply the Good; namely, as self-conscious and self-determining spirit, which constitutes the world in view of an end-the Good-and shapes its structure and process according to definite types and fixed laws-the Ideas? (2) There is the problem raised for him by that negative aspect of his system which we have just been considering-his tendency to exclude from genuine reality the sense-world and the human experiences and activities connected positively with it. Or, putting these two problems together, we may say, as was noted above, that what Plato has to face is a double incompleteness in his Idealism: an incompleteness at the top-i.e., in its conception of the highest principle; and a corresponding incompleteness at the bottom-the inability to comprehend the sense-world as an organ and manifestation of the highest reality. Secondly, with regard to the positive insight which Plato carries forward from his earlier Idealism to his later, what we have to remember is this.-If you have been led to draw a line through the universe, and to say that what is above this line is truly real, while what is below it is unreal, or only partly real, that mistake is not necessarily a fatal one. For if, with regard to what you do consider as real, your method is the true one, the synthetic one, it is likely sooner or later to break the barrier which you have erected around the field of its operation, and to go forth to reclaim the banished parts of the universe. ${ }^{1}$ And this is very nearly Plato's case. For, however prone he occasionally may be to look upon the things of the sense-world with the eyes of a Mystic, yet, as we have already seen, when he comes to describe what to him is the genuine, the undoubtedly real, world, his method is the thoroughly synthetic method of Concrete Idealism.

1 In which case your original distinction into real and unreal, substance and shadow, is almost certain to pass over into the perfectly sound and necessary distinction (insisted upon in our own day by Mr. Bradley) between the degrees of reality which things have accordingly as they are lower or higher manifestations, less or more adequate media. of the supreme principle. Cf. Caird, Evolution of Theology in the Greek Philosophers, vol. I., pp. 193-197 and 221-259. 


\section{PLATO AND THE FOUNDING OF IDEALISM}

The real world, precisely in the name of which he sometimes denies and denounces this present world, is to him no ineffable One. It is a world rational and rationally organised. Rational, for it is made up of rational forms or energies (the Ideas) and rational distinctions are of its very essence. And rationally organised; for it has one supreme principle, the Good, which is a true universal of universals-no mere abstracted common element, but an eternally creative energy, a truly active and organising principle, the source and home and explanation of all the other Ideas, of all their differences, of all their determinations, and therefore of their whole reality and their whole knowableness. Thus we may say fairly that the central battle of Idealism is already won in the thinking of Plato's middle period. In fact, we have seen reason for saying more than that. As a special evidence of how that central victory extends itself along the whole line, we have had to mark the way in which Plato causes the interests of the ideal world to come over and prevail concretely in this, in two great realms, education and the state: education as advancing through orderly stages toward the apprehension of the Idea of Good; the state as the human institute for its concrete realisation.

We have to turn, then, to the last stage of Plato's thought. In it, as was noted above, we seem to come upon something new. The Ideal Theory seems to have fallen into the background, and a new inquiry to have been made into the constitution of the world, which leads directly to the conclusion that the world is a work of active intelligence. Really, however, the advance is continuous, as we shall see if we follow its own line of movement. Let us consider, then, somewhat more fully just what the problem is, which arises for Plato out of the dualism, the two-world theory, toward which the facts of life had in earlier years driven him. The problem raised by the separation of the two worlds-whether the antithesis be left sharp and hard, or modified into something not far from organic connexion-is twofold. ${ }^{1}$ First, how came this present world into existence at all? Reality is with the other world. Then this world, if it has any reality at all, must have its source in that world. But why does that world, complete in its

1 A twofold problem which, it may be observed in passing, has haunted theology even more than philosophy. 


\section{PLATO AND THE FOUNDING OF IDEALISM}

eternal perfection, go beyond itself, to constitute another world, its counterpart or its shadow? What is there in its nature which impels it thus beyond itself, and leads it to communicate itself, and drives it to the energies of creation? Secondly, if that world is the source of this, how is it that this world departs so far from the nature of that? how is it that that world has given rise to something so much unlike itself-nay, so contradictory to itself? How from that world of reason and purity, of blessedness and perfection, has this scene of imperfection and pain, of sorrow and an imprisoning body, of folly and madness, arisen? It is with problems of which the foregoing is a statement in modern dress, that Plato deals in the great group of dialogues-Parmenides, Sophist, Statesman, and especially Philebus and Timaeus-in which his philosophy, laying aside at times its charm of expression and showing itself grey with the labour of thought, reaches its height of metaphysical comprehension.

First, then, how came this present world into being at all? How came the world of Ideas to go outside of itself, to go beyond its own completeness and perfection and become the source of another world? Here it may be advisable to pass at once to Plato's final answer, then to come back and follow the argument by which he leads up to it. That final answer is given by an interpretation (seen in preparation in earlier writings) of the character of that supreme principle of the real world, which formerly Plato had called the Idea of Good. It_or following Plato's example in the Timaeus let us say, he- "was good, and the good can never have any jealousy of anything. And being free from jealousy, he desired that all things should be as like himself as they could be."1 That is to say, it is of the very nature of the supreme principle to communicate itself, to impart to others its own being and character and blessedness; so that the nature itself of the supreme principle is the ground of the existence of beings, other than the supreme principle, and yet sharing in its nature and, therefore, in its reality.

So far as this conclusion prevails-we shall see presently that Plato was not able to carry it out into all its consequences-it is Concrete Idealism. The advance to it which we have now to consider,

1 Timaeus, $29 \mathrm{E}$. 


\section{PLATO AND THE FOUNDING OF IDEALISM}

was a long one. Its central conception, that the supreme reality does not stand apart, but is the fundamental energy of the whole process of the world, and that it is so because by its very nature as goodness it is essentially self-communicative-a conception with which Plato, myths or no myths, is thoroughly in earnest-is already present in the comparison of the Idea of Good to the sun ${ }^{1}$ in the latest-written section of the Republic; and also in the criticism of Anaxagoras in the Phaedo. ${ }^{2}$ But the dialectical conquest of it was no quick or easy process. It is worked out in that group of dialogues which, logically and perhaps chronologically, opens with the Parmenides and closes with the Philebus. This great piece of dialectic has two sides; a side polemic, a side constructive.

The polemic side-with an occasional pause to crush the head of materialism or sensationalism, when these happen to cross the pathis directed in the main against that great argument of Parmenides which shuts reality up into motionlessness for ever. The spirit of Parmenides was very congenial to Plato, and wrote itself deeply upon certain aspects of his earlier Idealism; "my father Parmenides," Plato might have said as appropriately as the Eleatic stranger of the Sophist. ${ }^{3}$ Yet the two systems are at bottom completely irreconcilable. If the argument of Parmenides could have secured full right of way in Plato's mind, it must have shattered any form whatever of Idealism; must (considering the religiousness of Plato) have led him at last to a complete Mysticism. So that even the earlier form of Plato's Idealism was built up in the face of Parmenides. And if there was to be any development of that earlier Idealism, it must make its way, so to speak, over the dead body of the Parmenidean argument. The argument of Parmenides, then, Plato shatters in the one way possible; namely, by attacking it at its source and taking away that radical disjunction of being and non-being, of is and is not, upon which it is based. This is done by showing that non-being exists and is a kind of being; the meaning of which, in modern speech, is, that reality is not an indivisible one, but that there are differences and distinctions

1 Republic, $506 \mathrm{E}-509$.
3241 E. 


\section{PLATO AND THE FOUNDING OF IDEALISM}

within it; that reality, so far from being an undifferentiated and ineffable unity, is a rational system. ${ }^{1}$

This having been done, the way is open for the constructive advance. By a very keen argument (which, it is worthy of note, proceeds explicitly from the question of the possibility of knowledge) it is shown that in true being there is motion- "motion and life and soul and mind." True being is not " devoid of life and mind." It does not " exist in awful meaninglessness, an everlasting fixture." And having mind and life, it must "have a soul which contains them." And, furthermore, having life and mind and soul, it cannot " remain absolutely unmoved." In the Philebus, the view thus prepared for comes to pointed expression. Mind is "king of heaven and earth." It " orders all things"; for " all this which they call the universe" is not "left to the guidance of unreason and chance medley," but is "as our fathers have declared, ordered and governed by a marvellous intelligence and wisdom."'3

Thus, then, the real world comes explicitly to be conceived as a world of rational activity, and its highest principle as at once the supreme intelligence and supreme energy of the universe, acting in "creation" and in "providence" 4 according to its nature as reason and goodness. And with this the view of the Timaeus, stated abovethe view that the perfect God, being good, is led by His nature to communicate Himself and so becomes the author and father of the universe-is made possible, not merely as a prophetic insight, but as the culmination of a reasoned Idealism.

So far, we have been following Plato's own line of advance. But at this point let us stop to consider how far the problems left over from the earlier Idealism have been met in the argument just outlined. Those problems, it will be remembered, were two: one, so to speak, at the top, the other at the bottom, of the Platonic Idealism; one connected with the conception of the highest principle, the other with the interpretation of the sense-world. And the latter breaks again into two: (1) Upon the two-world theory, how do you account for this

1 Sophist, $241 \mathrm{E}-260$. It is interesting to compare Hegel's Logic.

2 Sophist, 246-249.

3 Philebus, 28.

4 Timaeus, 30. 
present world at all-why, when the real world is eternally perfect and complete, did it go out of itself to give rise to another world? (2) When the real world became the source of this, why did it apparently contradict its own nature, giving rise to a world so different from iself, so imperfect and so evil? It will be seen that the argument which we have just been following, brings forward-though it does not with any fulness articulate- the conceptions necessary for solving the first of these problems and the first part of the second. And it furnishes a basis for dealing with the remaining part of the second. For such a view makes it possible to regard this present world as in organic connexion with the highest principle of reality. When that principle is viewed as active and self-determining reason, and as a goodness which cannot remain in itself, but is led by its very nature to go out of itself and communicate itself, it is scarcely possible to regard this present world, and all worlds, - "all time and all existence"-as anything other than as the field of its activity, the process in which it fulfils its own nature by communicating itself and so realising the Good. And such a view, if he could clearly have entered into it, would have enabled Plato to look with eyes of faith upon those aspects of the present world which so grieved him. Its imperfection, its struggle and unrest, its tragedies of unrewarded toil, of baffled devotion, of defeated righteousness, would have been accepted by him as elements in a process in which a wisdom, too vast for us to understand its separate steps, is fulfilling itself.

Does Plato, then, take this last step, which would have made his Idealism as thoroughly concrete as is possible to human insight? The anwer falls into two parts.

First, he took up positions which look toward it, which, one might almost say, contain it implicitly. In the Philebus, for instance, he puts the capstone upon the argument which was outlined a moment ago by applying it directly to man's life. The characters of the divinely organised universe-Beauty, Symmetry, Truth ${ }^{1}$-are to be adopted by man as the characters to be realised in his own nature and life. But the most striking instance of all is furnished by a work of Plato's which is described sometimes as a falling from faith, as a 


\section{PLATO AND THE FOUNDING OF IDEALISM}

forsaking of the height for the lowland, or even as an example of the hollowness of philosophy which fails its disciples at the last; but which in truth is one of the most nobly pathetic chapters in the spiritual history of man. For that is what we must say of the Laws when we consider the position it holds in Plato's life. Much earlier, as was pointed out above, the essential concreteness in the temper of his Idealism manifested itself in his devotion to the state. It had been the greatest work of his middle life to set before his disciples a picture of the state as it should be. Then, in later years, endeavouring to make his presentation of the true polity more concrete, he entered upon that magnificently conceived design which would have given an almost epic completeness to the Republic, but of which the Timaeus is the only finished part. The ideal state he had described. Now he would show it taking its place and discharging its function in the world, holding its own in struggle, and showing " by the greatness of its actions and the magnanimity of its words in dealing with other cities a result worthy of its training and education."' To this end, Timaeus was to begin with the generation of the world and carry its story down to the creation of man; and then Critias was to receive the men thus created, and show the place and life and work of the ideal state by describing how an Athens, which once was, maintained the freedom of the whole of Europe and Asia, when a mighty power from the Atlantic made an expedition against them. ${ }^{2}$ But even this was not enough. The desire to bring the ideal into some more feasible connexion with the life and ordinary nature of man, led to another step; and that step was the Laws. At the end of his life, when we should have expected his connexion with the world to be growing fainter, his aloofness from it to be increasing-precisely then it was that Plato, seeking at least some measure of the effective operation of the heavenly ideal in the affairs of the earth, bent his sublime head, and turned to the daily life and unaspiring minds of men, and outlined-in a collection of sketches and fragments edited by some later hand-a " second-best" constitution, more applicable, as he thought, to the life of this present world than that polity which in earlier days he had sketched in strict

1 Timaeus, $19 \mathrm{C}$.

2 Timaeus, 27A, 24 E. 
following of the pattern laid up in heaven. The endeavour of the Laws is no apostasy from Idealism; it represents no loss of belief in the heavenly pattern. But it is a recognition that there is a difference between heaven and earth, between the eternal ideal and the present state of human affairs; that, therefore, it is vain to expect in one step and by one single stroke to realise the order of heaven in the life of the earth; for the ideal realises itself through many intermediate stages, and the only way to the heavenly glory is by making the best of this present twilight. Indeed, Plato almost reverses what we commonly take to be the normal relation of the abstract and the concrete theology in a man's life. We usually expect that a man will begin life with delight in this world, with thoughtless participation in its interests and enjoyments; and then, when he grows old and the graver and longer interests of the soul enforce their claim, that he will look away from this world toward heaven. But Plato belongs to another order of men. These, by native purity and loftiness of mind, aided, it may be, by some hopeless sorrow, are brought early in life to feel that "whatsoever is not God, is nothing, and ought to be accounted as nothing." 1 And from this they draw the great practical lessons, de neglectu omnis creaturae, ut Creator possit inveniri, and de se tenendo tamquam exule et peregrino super terram. ${ }^{2}$ But as life goes on, and reflexion deepens, and religion joins hands with reason, and the world's great need forces itself upon the mature soul, more and more they turn, with a certain grave and wistful devotion, to take their places in the world and to give their hearts to its labours, its interests, its causes. And Plato, though there was no statesman's post for him at Syracuse or Athens, found at last his place. It has already been noted how his defeated passion for the state answers to the defeated political hope of Wordsworth. The parallelism holds to the end. Each found, for the problem of his practical life and personal activity, the same solution; of each, one can say in Windelband's fine expression, ${ }^{3}$ seine That ist seine Lehre. For each, the defeated passion in him, and the mighty thoughts that had grown in the soil of that

1 De Imitatione Christi, III. 31. 2.

2 Ibid. III. 31, and I. 17. 1.

3 Platon, S. 29. 
defeat, found expression by voice and pen; and, finding expression, entered upon a field of influence greater than ever was given to statesman entrusted with the framing of constitutions, or the administering of affairs, in Sicily or Athens or Paris; going forth to be a guide and an inspiration, while the world of men continues, to the highest hearts in every land.

There are, then, in Plato's later thought-especially in his practical interest, his interest in education and the state-positions which imply the organic connexion of this present world, marred though it is by evil and unrest, with the final principle of reality. But, as was indicated above, this is only part of the answer to the question now before us. The other part is, that with regard to the world of sensible experience, this implicit view is never brought to clear articulation; on the contrary, in Plato's express doctrine the opposite view prevails to the end.

In the last analysis, the cause of this failure clearly and unwaveringly to view the world of sensible experience as a manifestation of the supreme principle of reality lies in the fact that Plato's latest conception of that supreme principle never quite comes to its rights. If he had been able clearly to articulate his conception of that principle as active intelligence and self-imparting goodness -in one word, as self-determining and self-communicating spirit-he would have been compelled to view the sense-world, and our experience in it, as a stage of the process in which that principle is fulfilling its nature and realising its purpose. But only in many ages, only in many leaders of the thought of the ages, could so great a work be done. To no one man was so great an intellectual achievement possible. Plato, we may say, hit the core of the solution; but it was scarcely given to him to go back over all his system, and in the light of that central truth to work it into a thoroughly articulated view of the world.

For one thing, ancient thought had not clearly apprehended the nature of self-consciousness or spirit as it is in man himself. When you have seen that the self-consciousness, which is man, in a sense constitutes its own objects and so "makes nature"; and that in doing this it exercises a synthetic power-is an active principle of unity in 


\section{PLATO AND THE FOUNDING OF IDEALISM}

diversity, linking many facts into one experience and thus constituting both the facts which make up the experience and the experience which is made up of the facts:-then you can advance with secure footing to the view that the principle of union implied in the existence of the universe is a self-conscious and self-determining spirit which constitutes and links into one system the apparently conflicting facts of the world, and through many stages wherein men suffer, and are blessed, and at last become truly themselves, realises its purpose. But an insight into the synthetic or creative energy of self-consciousness as it is in man never became the explicit point of departure for Hellenic thought. ${ }^{1}$ Hence, while it was possible for Plato to come to the belief that mind is "king of heaven and earth" and "orders all things," it was scarcely possible for him to articulate that belief into a thoroughly organic view of the world.

We shall best see this, however, by turning to Plato's own treatment of the problem now before us. Granted-so that problem stands -that the supreme principle of the real world, being good, must go beyond itself to communicate its nature and impart its blessedness, why must the created world be one of imperfection? Why is it not like its source in perfection and blessedness? Has not the supreme principle, in going out into such a world, contradicted rather than obeyed its own nature?

The part of Plato's theory which corresponds to this question may be put in this way.-When the supreme principle goes out of itself upon that creative activity, into what region does it go forth? Manifestly into the region of non-being. So that the created world is a mixture of being and non-being. That is to say, it is a world of becoming, and therefore of imperfection, and of all the evils of imperfection.

But such an answer has two possible meanings. Upon the first meaning, the total explanation of this going out into the region of non-being and creating there a world which is a mixture of being and non-being and is, therefore, subject to imperfection and evil, lies in the divine nature itself which thus goes forth. In other words, it is affirmed that the supreme principle must begin its creative work with 


\section{PLATO AND THE FOUNDING OF IDEALISM}

something less than perfection-something less than completely realised "Being" - in order to achieve its purpose at all. If it is to fulfil its purpose, that communication of itself to other beings to which it is impelled by its nature, must not be a creation of perfection by perfection. For in that case the perfection of the created beings would be, after all, a sort of sham battle; would be a sort of gaining the goal without running. To lay aside metaphor, it would be only an apparent perfection, being radically flawed by the fact that those who have it, were absolutely passive in the acquiring of it. If it is really to be their perfection, and not just a divine perfection laid upon them from the outside, they must themselves conquer it; they must themselves be active, must themselves labour and suffer, in the process of its attainment. They must, therefore, begin not at the top of the scale, but somewhere lower. In Plato's language they must begin out in the region of non-being. Beginning there, they must work their way toward true and pure being, by a process in which their own labour and struggle is answered by ever increasing impartations to them of the divine nature.

This, then, is one possible meaning of the view that creation is a process in which being goes out into the region of non-being; and that the world which arises is consequently a mixture of being and non-being, an order, that is to say, of becoming and imperfection. And such a view is Concrete Idealism. For it sees this world of time in organic connexion with the realities of eternity. It sees this present order of things, and our human struggle upward through its imperfection and evil, as a process in which, by no sham battle, but by most real achievement, the divine nature fulfils itself by imparting itself to other beings.

But upon the other meaning, the explanation of the fact that the created world is blended of being and non-being is made to lie, not in the essential nature and conditions of the divine activity in creation, but in the nature of the region of non-being into which that activity goes forth. Non-being, that is to say, really is viewed as a second eternal principle of things. It is regarded as having a nature of its own, power of its own; as being able, by its stubbornness, its recalcitrancy, its unsuitability to the divine forms which are to be impressed 


\section{.PLATO AND THE FOUNDING OF IDEALISM}

upon it, to thwart or impede the creative energies of the divine nature, and so to diminish the perfection of the created world. And upon the whole it is to this view that Plato is driven. His general description of non-being - that it is a mere potentiality of taking on form, an incomprehensible something which receives all things $;^{1}$ his particular description of it is empty space ${ }^{2}$ - - these pass over into statements which imply that non-being is, somehow, more than a mere empty field in which being can work, more, that is to say, than the mere possibility of creation. It has a power of positive resistance in it; this is explicitly called Necessity, ${ }^{3}$ and is viewed as a co-eternal principle able to limit and hinder the purely rational creative energy, so that the resultant world is not purely rational, but is a mixture of sense and reason. ${ }^{4}$

So that to the end there is a measure of dualism in Plato. Indeed, for him there is no escape from it. For, on the one hand, he was acutely conscious of the imperfection of the world. And, on the other hand, in his day it was not possible for human thought to conceive the intelligent and self-communicating goodness, which is the supreme principle of reality, as fulfilling its purpose of self-communication by a process which begins with something lower than its own eternal perfection; by a process, that is to say, which, to the created beings standing in it, is one of evolution and of the struggle and suffering that evolution involves.

IV.

Plato's philosophy, then, was one that laboured toward concreteness; laboured toward a conception of the highest reality as a mind perfect in reason and goodness, self-communicating, and therefore the author and father of a universe. But to the end that effort is in part defeated. Plato's acute sense of the evil in the present world makes him feel that it is deeply sundered from genuine reality; while, on the other hand, he has not entered sufficiently into possession of his

1 Timaeus, 51 A.

2 Timaeus, 52 .

3 Timaeus, 48 A, 56 C.

4 Timaeus, 44 (cf. Phaedo, 66). 
highest conception to be enabled-or rather, to be compelled-to view the supreme mind as a synthetic principle realising itself through the total process of the world.

So that a measure of the negative theology is in him to the end. And it makes him grave and austere. We have already seen how in the very years when his hold upon life and his delight in its greater energies must have been at the height, a certain stern and sad and uncompromising aloofness marked even his devotion to the state. Scarcely can the true statesman bear rule in the city of his birth. The " city which is his own" has its pattern laid up in heaven. It he will seek to behold, and in accordance with it will organise his life. But "with any other city he will have nothing to do." And something of this temper remained in him throughout life. Hardly can he reconcile himself to the world. To the last it stands at the bar of his thought as a product of perfect reason, but perfect reason working in an alien realm and upon alien material and prevented thereby from fulfilling itself; while the religious spirit in him feels instinctively that the reality with which it longs to be at one is something far other than this world, something far removed from the whole order of things, the whole system of life, which has its being in space and time. And so to the end he continues to speak in that characteristic note and tone which in all ages has drawn to him high and pure hearts to whom the penetrating insights of his science were a closed book-the note and tone of the man who, having lifted up his mind to the things that are eternal, prophesies against the world, and exhorts men to fly from the world to God.

Thus the Greek spirit was transformed in Plato. Its mastery over the resources of the present life, its habitual delight in the activities of the day that now is, its quick susceptibility to every interesting thing and every beautiful form that the world affords, its proneness to lose itself in these and make the most of them before the evil days come in which the pale shade has no more delight in life:-all this was in Plato, but in him as something that stands rebuked. Always he had disliked the volatility and fickleness of the Athenians of his day; always his sympathy had been with the grave strength of the men of 


\section{PLATO AND THE FOUNDING OF IDEALISM}

Marathon or the austere discipline of Sparta. And upon all this there had supervened an infinitely, profounder spiritual power, against which his science made gradual headway, but which it could never wholly overcome - the tendency of a pure and high mind, and of a heart religious with the religion of eternity, toward the absolute condemnation of the things of the world in the light of a vision of the heavenly perfection.

When the genius of Greece still was young, and interpreted the life of nature in accordance with the life of its own soul, it shaped out in legend an unintentional prophecy of this transformation which it was itself to undergo when its doom was descending upon it, and in the soul of its greatest son it turned itself toward the things of eternity. The daughter of the earth-goddess led the life of a happy child, playing among the flowers in the meadows of Enna, lost in momentary pleasures, absorbed in momentary griefs. Very direct and simple was the unity of her mind with the beauty that surrounded her, and with her home the kindly earth; and her heart was very close to her mother's heart-for there was no barrier of knowledge or of vision or of experience that could come between. But when Hades suddenly had taken her to him, and set her at his side on the inexorable throne from which the issues of all things mortal are seen; and when Demeter, making desolate the earth, had compelled the restitution of her child for the happier seasons of the year:--she who returned to Demeter's arms was not she who had gone. Persephone it was; but no longer the happy child of the Sicilian meadows. A stately queen she came, in her eyes the unfathomable wisdom of the kingdom of the dead, in her bearing the majesty of the dark king her mate, at her heart a grave astonishment as she looked upon the hapless creatures, her mother's friends, the men who till the earth, and struggle for things that pass away, and mourn as the objects of their foolish quests perish in their hands. Never while the system of the universe endured could Demeter have her child again. Henceforward she must walk through all her genial summers, companioning, not with a happy child, but with the majestic woman whose eyes, "imperial, disimpassioned," had gazed upon uttermost mysteries and ultimate doom. And yet it may be that Demeter, having thus undergone her fate, came 


\section{PLATO AND THE FOUNDING OF IDEALISM}

at last to find it good; for it may be that the nature of the Immortal Gods, unchangeable at her heart, caused her at last to rejoice with a joy that had never been in her life before, when she found at her side no longer the child that played in Enna and by night lay close to her mother's heart, but a companion god, thinking godlike thoughts, achieving godlike things, queen of the world of the dead.

The genius of Greece might in this almost have been speaking of itself. The philosophy of Plato is the Persephone's journey of the Greek spirit. In him it looked upon ultimate things, and so was led to regard with other eyes the life of the earth. And undoubtedly the " hidden wisdom of the world" was in this. For while it is true that the beginnings of human life, and its divinely appointed end, are in organic connexion, it is also true that the end is far from the beginning; a great journey, a mighty discipline, lie between. Earth and heaven are parts of one universe; but earth is very different from heaven, and the ascent is steep and long. The nature of the world, and the meaning of life, can be known only in the light of the divinely intended synthesis toward which the whole creation moves; but the very vision of that synthesis is false vision unless it makes clear how far apart the antithetic members of the system now stand, and how vast must be the process that reconciles them in the life of the ultimate city of God. Hence the men of the negative theology, though they have overstated their truth and made the difference between eternal reality and our present life absolute and hopeless, yet by their very insistence upon the difference itself, have done profound service to humanity. We all need their lesson; and need it the more that our age is altogether disinclined to learn it. A few can learn it in the school of the Mystics. But most of us, touched, if not controlled, by the scientific mind of our day, and devoted practically to mastering the things of the world, can learn it only as it takes on humane forms and goes hand in hand with the synthetic spirit of science. And precisely thus it is that it appears in the urbane but solemn teaching of the great son of Ariston. 


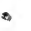


THE COMPLETING OF IDEALISM 



\title{
THE COMPLETING OF IDEAIISM.
}

\author{
I.
}

In considering the Idealism of Plato, we found that the positive tendency was not able in him fully to reach its goal. Something of the negative view remains with him to the end. In the world, he continues to the last to feel, there is a necessity which is no manifestation of the divine nature, no aspect of the divine activity, but an alien force able to prevent the divine nature, in its creation, from manifesting and realising itself as it does when it works in its own realm where time and space are not. So that even in his latest and ripest thought he still tends to condemn the present world, not only ethically, as an order of imperfection, but metaphysically, as not being truly real.

The ultimate cause of this incompleteness of the Platonic Idealism we must call again to mind. We saw ${ }^{1}$ that the highest conception of Idealism is the conception of self-determining and self-communicating spirit as the principle of union, the constitutive and governing power, of the universe. It is only through this conception that human thought can comprehend the possibility of the organic connexion and unity of all existences under one supreme principle in one completely rational world; only through it, that is to say, that Idealism becomes truly concrete. And we also saw that the place where man gains that conception of spirit is his own soul. When you have apprehended the self-consciousness which is man, as an active principle of synthesis; and have advanced to the thought of a self-conscious spirit, not discursive and defective as in man, but eternal and perfect, as the universal principle of synthesis; and have come thus to regard the order of the universe as an order constituted by that eternally active spirit, and the process of the universe as a teleological process in which that spirit fulfils its nature and realises its purpose by continually

1 Supra, pp. 61-79. 


\section{THE COMPLETING OF IDEALISM}

increasing impartations of itself:- then at last your Idealism is in its ground-lines self-consistent and concrete. For then, without contradicting your own view of the nature of ultimate reality, you can regard this world, and the conditions of our life in it, as in organic connexion with that ultimate reality. That eternal spirit, in going forth into a world of space and time, is not going out into an alien realm, nor working upon alien material, but is fulfilling its own nature; is acting altogether from itself, has the sources of its action altogether within itself. While from our side, this imperfect knowledge of ours is a stage on the way to perfect knowledge, this half-intelligent demotic morality a stage on the way to a morality that clearly apprehends the divine idea which it is fulfilling. The whole process of the world, in one word-with that imperfect knowledge of ours, and that demotic morality, as factors in it-is a process in which, stage after stage, through the struggle necessary to genuine achievement, the divine purpose is fulfilling itself, the Good being realised.

Plato's whole interpretation of the world as rational is a call for such a conception. In his treatment of the Idea of Good as the organising principle of reality, as the principle of knowledge, as the true end for man's endeavour, he is really struggling toward it. And at last, in the dialogues of the final period, he brings it to explicit utterance. But yet he does not enter into full possession of it as the instrument for the rational comprehension of the world; one great. province or aspect of the world he to the end leaves outside. $\mathrm{He}$ is unable to come to a view of the whole process of the universe as an evolution, in and through which the supreme reason, by communicating itself, realises its purpose; rather, he tends to the end to break the continuity between the real world, as a realm of fixed and complete perfections, and this present world, where nothing is, but everything with imperfection and sorrow is becoming. There must be, he knows, some connexion between the two. But he feels that the connexion is not continuous, not fully organic. Something which is a radical opponent of reality has intervened to break the continuity; and how that can be, he explains by the supposition that when the divine nature went forth upon its creative activity it worked in a region or upon a medium which was alien and intractable, so that the divine nature 


\section{THE COMPLETING OF IDEALISM}

could not do itself justice in its own creation; or rather its creation is not altogether its own, Necessity or non-being having also a part in it.

In Plato, then, if one may so speak, Idealism. reached its goal, but did not quite enter into possession of it. In this sense, Plato's was a philosophy that called upon the later world to complete it. And, whether with or without conscious reference to Plato, the later world took up the task. Indeed, one might almost say that the history of Idealism falls into two great chapters : the first, the story of its foundation by Plato; the second, the longer and more perplexed story of how the philosophy thus founded entered into clearer possession of its own highest conception, and so became better able to do justice to its view of the world as an order of reason and of righteousness.

As soon as we pass the limits of the purely Greek age, that second chapter in the history of Idealism becomes infinitely complicated. First, indeed, there comes a complete triumph of the opposite tendency-in the mystic theology and religion which had their most congenial home in Alexandria. And from that time on, the whole breadth and complexity of the history of the world enters into the history of Idealism. The rest of this book is to be given to a consideration of two single points in that history, which, however small a part they form of the total history, are yet sufficient to show the breadth, the depth, the vitality, the complexity, of the forces that worked there. But before we go on to that, a moment should be given to the question which meets us upon the threshold of what has just been called the "second chapter" in the history of idealistic philosophy. What advance in the direction of making Idealism more concrete by further articulating its highest conception, was made within the age of Hellenic thought? Without considering this question, on the one hand the attempt to understand Plato is left half-finished, while, on the other hand, factors that worked in the later history are neglected. So that at least a brief reference must be made here, first to Aristotle, secondly to the Stoics.

Aristotle, after insisting -in fact, over-insisting-upon the dualism in Plato, strikes directly into the pathway which leads toward the overcoming of it; or rather, which excludes it from the beginning. 


\section{THE COMPLETING OF IDEALISM}

For he comes to his constructive work with the insight that the real world consists of formed matter; that is to say, of concrete individuals. And concerning the individual things and beings which thus make up the world, two facts are clear. First, the universals which realise themselves in these individuals, do so only gradually. Individual things are not eternally or changelessly themselves. They come to be themselves; they pass from potentiality to actuality. Secondly, the individual things of the world do not stand upon a level. They form a scale of being, which is the system of the universe; a scale in which each individual is actuality to those below it, but matter or potentiality to those above. So that the universe is one great life or process, in the survey of which we are led upward from mere matter or potentiality to the realisation of ever higher universals. But secondly, in this movement from potentiality to actuality-whether we think merely of the formation of some individual thing, or of the total movement which is the process of the universe-there is always a priority of the actual to the potential. And that in knowledge, in time, and in substance. In knowledge; for it is only by seeing the actuality which a given thing may become that I am in position to view that given thing as potentiality at all. In time; just as the finished house in the architect's thought must precede the shaping of the separate timbers and stones, or as the fully completed growth of corn must precede the corn which is used as seed. In substance; because the end which a process is to realise is the true governing principle of the process; because, in other words, the $\tau \dot{\varepsilon} \lambda \circ s$ of a process is its true $\dot{\alpha} \rho \chi \eta^{\prime}$, its final cause its true efficient cause.

So far, then, we have seen (1) that the process of the universe is a process of movement upward from potentiality to actuality; (2) that to the existence and continuance of such a process, there is necessary a priority of the actual to the potential. But these two insights at once set a further problem: What is that actuality which is the prius of this whole system-this whole continuous and eternal world-processof potentialities and actualities? That prius must be eternal; must be self-active energy; must be actuality fully-realised and perfectactuality without any mixture of unactualised potentiality; must, in a word, be an eternal and self-dependent principle, which, by its very 


\section{THE COMPLETING OF IDEALISM}

nature, energises perfectly and to the full height of being. But how is such an energy to be conceived? This Aristotle answers by his great conception of self-consciousness. That fully-realised actuality which is implied in the process of the world, is an eternal and completely actualised reason which has itself for its object.

Here we seem on the very verge of the completion of Idealism, with regard at least to the system of its conceptions. But there is still a question to ask. That eternal self-consciousness, completely actualised and perfect, having in its own activity its adequate object:will Aristotle describe it as the creative and informing energy of the whole process of the world, so that the world is its thought, its activity, its objective consciousness, and it, as at once transcendent and immanent, is the source and the explanation, the home and the end, of the world?

If Aristotle could have done this, he would have brought his great argument to its consistent conclusion; would have done justice at once to his principle that universal and particular must not be separated, and to the call which his criticism of Plato makes upon himself; would have brought Greek thinking to its culmination in an Idealism of thoroughly concrete type. And at times-for instance, in his comparison of the order of the universe to the order of an armyhe does seem to put into express words precisely such a conclusion. But though his whole argument calls for such a conclusion and prepares the way for it, yet he cannot be said clearly and unwaveringly to hold it. For his own view of what reason is in its perfect exercise, lies in the way. Reason, he sees, to be perfect, must supply to itself its own object. If it receives its object from without, the result must be, in the case of the supreme reason of the universe, the intrusion of something non-rational. Of that supreme reason we must, therefore, believe that it is absolutely self-contained, supplying its own object, depending on nothing from without. While reason as it is in man must be regarded as a sort of combination in which an active element, corresponding to the divine reason, somehow goes along with a passive element which is connected with the body and its avenues of sense.

The view that the self-consciousness which is the supreme reason 


\section{THE COMPLETING OF IDEALISM}

of the universe, must be complete within itself, supplying its own object, is perfectly sound; might, in fact, be called an axiom. But it does not forbid the view of Concrete or Positive Idealism that the universe is the objective consciousness of God. Aristotle, however, takes it precisely so as to forbid that conclusion. Like Plato, he is acutely conscious of the imperfection of the world of our senseexperience. It certainly must be excluded, he feels, from that system of absolutely perfect reason which alone can form the objective consciousness of God. So that in his conception of God, and of the relation of the sense-world to Him, Aristotle is really more Platonic than that very side of Plato against which his severest criticisms had been directed. God's existence is perfect peace, exalted above all change and becoming. $\mathrm{He}$ is active intelligence, but $\mathrm{His}$ activity cannot be viewed as the carrying on of any such process of development as the world, nor can His intelligence have a world of change as its object. Rather His activity is one absolutely free from potentiality or becoming, and His knowledge one which can have no other object than Himself as perfect being and absolute truth. $\mathrm{He}$ is altogether self-contained; His blessedness consists precisely in that knowledge in which, as absolute subject, He has Himself as His own perfect and adequate object:- a blessedness which would lose its perfection, its peace, its exaltation above all change, if the divine activity went forth into any such world as that of our daily struggle, or the divine nature manifested itself in any process of becoming. God in His blessedness is a universe by Himself, complete, eternal, perfect. But the world of our experience, which the whole inquiry was undertaken to explain, and which up to this point it did explain, is here at one stroke severed from its own ultimate principle. Steadily the great argument had been carried forward. It had been shown that the process of development from potentiality to actuality which is the world, involves as its necessary prius an actuality, eternal, selfactive, having in it no unrealised potentiality; and that this can be conceived only as self-consciousness, only as a completely actualised reason. But when it remains only to put the capstone upon the whole argument by saying that God is the creative and constitutive energy of the world, and that it is through His communication of Himself 


\section{THE COMPLETING OF IDEALISM}

that individual things have natures and capacities of their own, and so are able to exist and energise and fill their places in the system of the world:-precisely then it is that Aristotle, in the way which we have just seen, is led to turn round upon his own argument, and to give it a conclusion opposite to that which its whole previous course had called for.

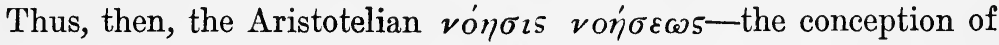
the supreme principle of reality as self-consciousness-does not lead to a view of the organic connexion of God, as the concrete and allinclusive universal, with the world, and with that process of development which is the history of the world. Not, indeed, that Aristotle evades the problem of the relation between God and the world. But he tends to make it a relation altogether from the world's side. As a lover moves toward a beautiful and beloved object, and is governed by the impulse to organise his life according to its form and nature, so the world moves toward God. In this sense, indeed, God, as the end toward which the world moves and which it seeks to realise, is the governing principle of the whole process of the world. But not through any activity on the part of God Himself. His activity can be no other than that of absolutely pure thought; and the object of such thought can be nothing other than the perfect reason which is Himself. In that contemplation He remains, perfect and unchangeable in blessedness for ever. ${ }^{1}$

Aristotle's view of what constitutes reason in its perfect exercise, coupled with his sense of the imperfection of the world of our sensible experience, was decisive, then, of the character of his Idealism. In fact, his conception of reason was determinative, as the Master of Balliol reminds us, ${ }^{2}$ in all the great departments of his thought. In

1 See, however, Caird, The Evolution of Theology in the Greek Philosophers, vol. II., pp. 11-30. Between the two interpretations, there is no difference with regard to the broad fact that Aristotle makes a virtually complete disjunction between God and the present world of change and contingency. The point in dispute is whether the line is drawn above or below the universals which are secking to realise themselves in the things of the world-above or below what Plato would have called the Ideas. In other words, is the object of the divine thought, the universals as a system of absolutely pure reason, lifted above all change and contingency, or is it God Himself in a sense which excludes these? On the former view, the step to an organic theory would be much easier. But, whether easy or hard, Aristotle does not take it. In the present world he continues to recognise a contingency with which neither God nor pure reason can have any connexion.

2 The Evolution of Theology in the Greek Philosophers, vol. I., p. 287 seq. 


\section{THE COMPLETING OF IDEALISM}

his ethic it leads him to rank the Intellectual Virtues in which reason deals purely with itself, above the Practical Virtues in which reason is in relation with a world of sense and change. In his psychology it leads to a disjunction of the two aspects of man's intelligence. There is a reason, eternal and existing separately, which makes all things. And there is a passive or receptive reason in man, which becomes all things. This, indeed, might seem a convenient form for working out an organic connexion between the universal principles of the world and the particulars of our ordinary experience. But the connexion of the two reasons in man seems after all to be only an external one; at the death of the body it is dissolved, passive reason perishing with the body in relation to which it existed, active reason continuing in that independent and unmixed existence which either is, or is like, the divine existence. And of the disjunction which thus runs through every part of his system, the separation of God and the world which we have just been considering is simply the highest and final instance.

It will be noticed that the logical motives of the dualism which thus remains in Aristotle, are the same as those we saw operative in Plato's thought; only Aristotle draws the lines more rigidly. Like Plato, Aristotle was keenly alive to the imperfection of the world. In it he found something essentially non-rational-an irreducible and intractable contingency, corresponding to that necessity of which Plato had spoken in the Timaeus. And in each case, this works in at once with the very natural conception that since the highest principle of reality is absolutely perfect, it cannot be conceived as working through, or in, any media except those that have an absolute perfection like its own; which means for Aristotle that in spite of his own conception of evolution as a way of nature, he cannot conceive it as a way of God. That for created beings the only genuine perfection is one in whose achieving they themselves have co-operated, and that therefore the divine creative activity must begin with something less than perfection:- - this is an argument which Aristotle cannot admit. He sees the imperfection of the world; sees the imperfection of our experience in it; but cannot conceive of God as working through such imperfection toward that true perfection which is wrought out only in struggle. God as perfect must be self-contained in the sense of 


\section{THE COMPLETING OF IDEALISM}

excluding the world of change; as complete actuality, having in Himself no unrealised potentiality at all, He cannot have an object lower than Himself, nor any activity lower than the contemplation of absolute perfection; the world of becoming, while it may be impelled by the inner principle of its life to move for ever toward Him, cannot be His workmanship nor the temple of His indwelling. Indeed, in view of this similarity in the inner logic of their systems, one may almost say that the difference between Plato and Aristotle is one rather of temper and manner than of fundamental logical motives or of ultimate conclusions. Aristotle works his way outward from his Idealistic centre to a great cyclopædia of natural and social science illuminated by Idealistic conceptions. But while Aristotle thus delights to work upon the circumference even at the expense of occasionally forgetting the centre, Plato prefers to remain habitually at the centre, and only from its lofty height to view the circumference. Hence Plato frequently tends-under the influence of the Parmenidean cast and tendency which remained in his many-sided intellect even after he had overcome the specifically Parmenidean argument, and under the influence still more of the lofty religiousness native to his character and deepened by grief and by high hope disappointed-to put the whole of the emphasis upon the centre and despise or even deny the circumference; thus really breaking the unity of his system through the very intensity of his instinct for that unity. While Aristotle, with his cooler scientific mind, gives attention to both centre and circumference, and yet wrongs both by setting them apart.

So far, then, for the first step in the history of Idealism after Plato. Aristotle, seeing the defect in the Platonic Idealism, and pointing out the way to overcome it, ends by retaining it; ends with the conception, not of a God who is the life of the world, and of a world which is the activity and manifestation of God, but of a world which has life in itself, and a God who dwells apart from it in the solitude of absolute perfection, in the blessedness of a contemplation in which a perfect subject gazes for ever upon a perfect object.

With Aristotle we are really at the end of strictly Hellenic thought. Already the wide world was breaking in upon Greece and 


\section{THE COMPLETING OF IDEALISM}

another age was preparing. But before we pass on to it, we must give a moment to the men who did so much in that preparation for it- the Stoics. These, though their first interest was practical-the search for a wise way of living-were genuinely great in metaphysic; indeed, without being so, they could not have been great in ethics. In metaphysic, however, the "root of the matter" is in a sense twofold. There is first the instinct for the unity of all existence; but, secondly, the instinct for doing justice to the individual existences within that unity and to the particular facts which make up the life of these. Without the first there is nothing worthy of being called philosophy; but the second must work with it to do justice to the wealth which the unity really contains. Now, the Stoics were weak in the lesser matters-and therefore in many of the greater matters-of the second. But they were victoriously strong in the first. Platonic and Aristotelian dualism they sweep out at one stroke. They have no doubt at all that reality is one-and that it is rational; no doubt at all that the supreme principle of reality is immanent in the world, and that it is kindred in nature to the reason which is in man; no doubt at all that man is capable of communion with it and of obedience to its ways, and that in that communion and obedience lie his freedom and his true way of life.

This seems a great advance. And in one sense it is a great advance. Yet we must make clear to ourselves what it does, and what it does not, contain. It is not enough to assert the true conclusion, unless you make it intelligible; not enough to assert that reality is one, unless you show how it is one. And this the Stoics were not in position to do; were far less in position to do than Plato or Aristotle. Still less than Plato or Aristotle had they proceeded from an apprehension of the reason in man as a synthetic principle-from that apprehension which led Kant to the emphatic statement about man's understanding that it "makes nature." And without this they might assert the rationality of the whole system and structure of the universe; but they could not articulate that insight. And such articulation is the business of systematic philosophy.

So that in the metaphysic of the Stoics we have to mark a double defect, each side of which intensifies the other. They despised and 


\section{'THE COMPLE'TING OF IDEALISM}

rejected certain aspects of experience, certain provinces of reality. And, holding the view that the world is rational, they could not give to that view its systematic articulation. But of course it is to be remembered that the true Stoic was first of all a soldier of righteousness, and only secondarily a philosopher of the school. He fought in the most cruel of all moral conflicts-that which arises from the decay of a great civilisation. Simplicity and uprightness seemed to be gone from the earth, luxury and wickedness everywhere to prevail. By nothing less than a general treason of society, the causes of right reason stood defeated. Upon the field of that lost battle, the Stoic lived his life; and as the shadows of night grew deeper, and the hideous forms that thrive in its darkness gathered more thickly around, he recognised it as his vocation to form no other ties than those of his soldier's duty, and to stand immovable at the post to which the wisdom of the universe had assigned him.

Aristotle, then, holds that the highest reality is a self-conscious and self-dependent spirit, existing separately from our world of change; while the Stoic holds precisely the complementary view, that God is immanent in the world as its reason and its life. But Greek thought was not able to work out, as a clearly articulated possession of the scientific mind, the conception which, by taking up both those sides into the unity of a more comprehensive view, would have enabled each of them to enter into its own proper significance and to unite with the other. That conception is not merely the conception of God as selfconscious and self-dependent spirit, but the further conception of Him as the self-conscious and self-determining spirit who is the subject of the world; so that the world is regarded as an activity or manifestation of God, the history of the world as a process in which a divine purpose is being realised; that purpose, again, not being arbitrarily or externally chosen, but arising out of and expressing the divine nature itself, and being capable of fulfilment, therefore, only by the gradual impartation of the divine mind and nature to man. For such an Idealism Greek thought assembled the materials; but scarcely was able to bring them to the unity of an organic structure. This was to some extent a matter simply of the order of time. In the history of 


\section{THE COMPLETING OF IDEALISM}

thought it is a conspicuous and much honoured part to set in place the keystone which makes visible to all the world the unity of the manifold building and of the varied labours that have entered into it. But first must come the more heroic workmen who, with only the prophetic instinct of science to guide them, lay deep foundations at what seem hopeless distances apart. And then, too, a fully developed Idealism requires an historical outlook such as was not possible to the Greeks; an outlook over successive ages and races, each doing its work upon the earth and passing away, and thus setting the mind of the spectator upon the search for some plan of the world or wisdom of history. And there was still another reason; one connected, not simply with the historical position of the Greeks, but with the intrinsic quality of their mind. As we have seen, Idealism arises when, seeking to know the world, you also know the soul and find in it a principle for interpreting the world. For the place where we apprehend the character of spirit as an active principle of synthesis, is in ourselves. Unless we have apprehended the nature and activity of spirit there, we cannot be in position to articulate clearly and consistently the insight that spirit is the principle of synthesis, the constitutive and organising energy, implied in the existence of the universe. But the Hellenic mind, while devoted to the objective interests of the spirit, was disinclined to set the individual soul before it in order to analyse its inner processes for their own sake. The strength, the intellectual tact, the unfailing clearness, of the Greek genius, were based in a certain large and calm objectivity, a tendency to fix contemplation upon that universal structure of things which was felt to be at once more real and more worthy than the single soul in its individuality. And this objective tendency of the Hellenic mind was the source at once of the greatness and the incompleteness of Greek Idealism.

But this indicates to us in what direction we must look, if we would see the Idealistic or spiritual view of the world completing itself from within. We must look for an age, or a type of experience, in which the individual soul becomes a thing of supreme value, and, in a profound and worthy sense (i.e., without sinking into mere subjectivism, without losing objectivity of view and of interest) is turned in upon itself. And precisely such a type of experience was now to 
become the chief factor of human history, in a religion which, so far as it could be faithful to the whole of itself, did not turn its eyes away from the world, and yet was a religion of the inner spirit; a religion in which the struggles and attainments of the inner spirit are viewed as the most real thing in life, and therefore as that in the world which most truly expresses the nature and meaning of the world.

II.

Such a religion-a religion that from the inner spirit goes forth to the world and to the whole breadth of the interests of the worldwas Christianity; Christianity, at least, as it existed in the mind of its Founder, or as it struggles in human society to be faithful to that mind. Jesus, in His daily life and habitual consciousness, looked upon those eternal relations of man's life which are the order and structure of the universe, with an objectivity as large, as calm, as unfailing, as that of the Greek mind itself; and looking thus upon them, $\mathrm{He}$ expressed them in terms of the spirit. He searched the inner spirit; but he did not shut men up to it. Freely He looked upon the world; freely, turning His eyes away from nothing, He regarded the whole order and structure of it, the whole constitution of things in which man lives, the whole array of the conditions of our life. ${ }^{1}$ And as $\mathrm{He}$ looked with this clear and open gaze upon the world, not all its imperfection, not all its evil, could make Him waver for a single instant in His consciousness that the relations which constitute its order and the order of man's life, are ultimately spiritual, ultimately moral-nay, immediately spiritual, immediately moral. His consciousness of God He habitually expressed in the words, My Father; His consciousness of the relation of God to the human world and of the human world to God, in the words, Our Father. Man's life, that is to say, is a communication of Himself on the part of God; the universe, a society of spirits which God constitutes and administers as His family. With

1 Even with "nature" in the more restricted sense of the word-the external world, the birds and fields and lilies-He lived as a man might live with the things of His home (see Caird, The Evolution of Religion, vol. II., p. 122 seq.). It would indicate a truth, were one to say that the view which Wordsworth took of nature poetically, Jesus took religiously. 


\section{THE COMPLETING OF IDEALISM}

Him and with the ultimate realities of eternity we all stand in intimate organic relationship: whatsoever we do to "the least of these," we do to Jesus and therefore to the Father; or again, to choose an instance of a different character, Jesus habitually speaks of eternal life as a present possession.

And of such a view of the world as a system over the whole of which the love, the righteousness, the wisdom, of the Father extend, " reaching from end to end, sweetly and strongly ordering all things," - of such a view the practical attitude of Jesus was, if possible, even more expressive than His words. He lived a life of absolute confidence in the Father: absolute confidence in the Father's administration of the world; absolute confidence in the reach of that administration over every side of man's life, over every aspect of the world and of its history; absolute confidence in the supremacy of the Father and in the inability of any power to defeat His purpose; absolute confidence, therefore, in the good, and in the impossibility that any labour for the good can ultimately be without its due effect. This confidence in the Father who "sends us," and in the good which is His purpose, was the habitual mind of Jesus. He saw human life as human life actually is; He faced all the sufferings of men, all the sins of men, all the sinfulness of men, and never lost hope, or fell into bitterness, or held back in misgiving; but remained absolutely certain that through all this stricken and troubled process of the world's history omnipotent goodness is at work realising its purpose. Hence He taught that the man who really saves his life is the man who loses it by devoting himself to that divine purpose and making himself its organ $;^{1}$ and $\mathrm{He}$ gave to His belief in the organic relation of the human world to God the most decisive of all possible expressions, by seeking to win men's hearts and to lead them toward a consciousness of God similar to His own and toward the way of life which arises from such a consciousness.

Such a confidence in God, such a belief in the possible unity of the affairs of the world with the divine plan, it was that Christianity carried with it, as it went out to be the religion of the world. Implicitly-not as a possession of the intellect, but as an inner spirit of faith and of life-it held the view that the world and the history of

1 See Caird, The Evolution of Religion, vol. II., pp. 88, 104-5, 137. 


\section{THE COMPLETING OF IDEALISM}

the world stand in organic connexion with the ultimate God. But Christianity was certain to come more and more to intellectual possession of its implicit faith. For the world out into which it went was that Gentile world which had inherited the intellectual spirit of the Greeks, and their impulse to bring implicit beliefs to the light of day in the form of ordered science. ${ }^{1}$

But the history of this entrance of Christendom upon the intellectual possession of its own implicit view of God and the world, is perhaps the most complicated of all human histories. In the first place, there is a complexity from within. Christianity could scarcely advance immediately to the apprehension of the organic connexion of God and the world. It was inevitable that the advance should be, in a sense, dialectic; should be an advance through antithesis to synthesis. For Christianity has in it the possibility of both the forms of the religious temper distinguished on a previous page. ${ }^{2}$ With the acute sensitiveness to all evil, the imperious consciousness of sin, which it introduces into life, it tends, both with individuals and the church, to assume at the beginning the more negative of the two forms. Under this form, it leads men to condemn not only their sins and their sinful tendencies, but the whole of their nature and the whole of the world. Thus it becomes a principle of separation from the world; and to the negative implied in its positive gives so great a place as to obscure or even defeat that positive itself. Such religion, too, is commonly the religion of intense natures. Hence, when it gains hold upon the church, it is as a rule only slowly and with struggle that the advance beyond it is made. Soon or late, however, the advance must come. For, in that form, Christianity, though an intense and heroic religion, is involved in a deep contradiction with itself, with the mind of its founder, and with reason. It cannot see the world as a work of God; and instead of saving it, leaves it to those of its powers which are most unlike God. Its inner principle, that is to say, is working under

1 Hence it is strikingly appropriate that the man who formally completed Idealism in its Platonic type, was a Father of the church-Augustine, who on one of the many sides of his intense and eager thought, made the Ideas (the norms upon which human thinking proceeds, but which manifestly go beyond the individual mind, and have a universal validity) to be forms or standards in the divine mind.

2 Supra, pp. 221, 222. 


\section{THE COMPLETING OF IDEALISM}

limitations which contradict that inner principle itself. Hence the forces which make for human development, continually impel that principle to fulfil itself by going beyond those limitations. Reason, which is irreconcilably an enemy to Manichæism; experience, which shows how genuinely great are the world and the natural mind of man; the love which carries the individual beyond himself and beyond the limits of his church or order to the service of the imperfect world; the mind of the Founder, exerting itself in the church:- these produce gradually their effect, and the mind of Christendom comes more and more to apprehend that the world stands in organic connexion with God, the things of time with those of eternity, the conditions of man's present life with the divine plan.

But secondly, this internal complexity and struggle is deepened by struggles and complexities from without. For Christianity became the central stream of human history. To it, every current of human thinking, of human passion, of human achievement, every scientific tradition, every type of religion and of religious aspiration, became tributary, bringing clear or troubled waters, which partly were received and assimilated, partly were hurried forward in rival and contending currents. Virtually all the types, and all the divisions, of man's science, of his philosophy, of his greater religion, entered and exerted their influence; so that he who would trace the development within Christendom of the conception of God and the conception of God's relation to nature and man, would have to make himself acquainted in the end with nothing less than the whole scientific and religious history of the human race.

In the pages that remain, not even a beginning can be made at the telling of that great history. ${ }^{1}$ But the impression which it is the business of this book to convey-an impression of the two fundamental tendencies in the endeavour of the soul to move intellectually and practically toward reality-calls for at least some indication of the complexity of the development now in question; calls for at least some glimpse of the variety of interests and insights operative in it, of the crossing, the conflicting, the involution, of its intellectual and emotional and moral factors.

1 A condensed outline, firmly and clearly drawn, of the more positive side of it, is given by Principal Fairbairn in Book I. of his Place of Christ in Modern Theology. 


\section{THE COMPLETING OF IDEALISM}

In attempting to give such an indication, it is scarcely possible to touch the modern world. On the practical side, the story is too hopelessly vast; and the issues are not yet clear. On the side of thought the history is easier to follow; and there are two specially striking examples of the direct entanglement and conflict of the two tendencies - Spinoza and Kant. But with Spinoza we have already attempted to deal. While that veiled conflict of the abstract and the concrete movement of thought, which ran through the whole structure of Kant's critical philosophy, has been laid bare for us by the Master of Balliol in an exposition which is one of the masterworks of English philosophical literature. But for the present purpose the mediæval world is almost more instructive than our own; because in it life and thought went more closely hand in hand. Turning to it, we are to attempt to deal with two single points which illustrate the wealth and complexity of the forces at work. The one is Erigena's view of the Division of Nature; it goes beyond the story of the inner development of Idealism, and takes us back to that ultimate antithesis with which we were concerned on earlier pages; for it shows the Idealism implicit in Christianity almost overborne by Neo-Platonic Mysticism. The other is an aspect of Aquinas' conception of the relation of the world to God. It shows us that implicit Idealism struggling toward a thorough expression of itself, but crossed just at the culmination by a dualism very similar in motive to that of Plato and Aristotle. 
ERIGENA : THE DIVISION OF NATURE 


\section{ERIGENA: THE DIVISION OF NATURE.}

Men more different than Erigena and Spinoza it would be hard to imagine; or philosophies more different in atmosphere and outward appearance than Spinoza's with its severity of science, and Erigena's with its radiance of mystic passion. Yet in the inner logic of the two philosophies there is a similarity: each in its own way shows us the affirmative method and the negative dwelling together in a single mind. This was due in part to the very nature of their endeavour. As men of philosophy and of religion, they strove to see the world as One; strove to pass from present appearances to eternal reality. But, as we so often have seen, ${ }^{1}$ there are in such a movement of thought two possibilities. We may see that the present appearances must somehow be in organic connexion with eternal reality; for else the world is hopelessly rent in twain, and the very unity that we set out to find is lost. But, on the other hand, we may be so overwhelmed by the differencesetween reality in its oneness and perfection, and the appearances in their dividedness and evil, that we refuse to regard these appearances as real at all; they are deceptions-shadows of the cave-coloured veils breaking up the pure light of the One. And between the two possibilities, thus inherent in the very nature of their task, both Erigena and Spinoza divided their hearts. But the form which this division of mind assumed was determined for each by his own special circumstances; in each case there was a preceding history leading to the presence and combination of the two tendencies in one outlook upon the world. For Spinoza there stood on the one side the modern attempt to apprehend reality by the use of the category of Substance- the Cartesian tradition, whose last prophet is shut up to the belief that reality is One Substance, and all manifoldness an illusion. On the other stood the newly-developed physical science, whose temper and point of view formed part of Spinoza's very soul.

1 Cf. supra, pp. $7-11$; p. 83 note; p. 117 seq.; p. 216 seq. 


\section{ERIGENA: THE DIVISION OF NATURE}

With Erigena, the diverse traditions that made up his intellectual inheritance lay closer to historical religion. First, there was the early history of Christian theology: the Apologists had wrought out a largehearted theory of divine revelation, of God's manifestation of Himself in general and special forms to all the world; and then Fathers and Councils had formulated the doctrine of the Trinity. But along with this Christian theology and strangely interwoven with it, there came another type of thought: the philosophy which called itself by Plato's name, but really was the summing up and the testament of the ancient civilisation that had gone down to death, and in dying had turned its eyes away from the world to an absolutely transcendent God.

Such a combination of Christianity and Neo-Platonism might have seemed beyond possibility. For whether viewed as theologies, seeking to pass from the manifoldness of the world to an apprehension of its eternal unity, or as religions seeking the way of life by which man becomes at one with that supreme principle, the two represent the greatest possible opposition of method and tendency. Extreme opposites they were, too, by historical position. Neo-Platonism was at once the ultimate vision and the dying voice of the ancient world; Christianity was the vital life of the new. And this opposition of nature had manifested itself in open hostility of actions. Neo-Platonism, in the stress of its conflict, had made alliance with the cult of the ancient gods. Nothing could better have marked the Neo-Platonist's sense of the irreconcilableness of his theology with the Christian; nor, in the eyes of the Catholic theologian, could more thoroughly have displayed Neo-Platonism as damned beyond all hope.

But though the old world was gone, and relapse into any of its faiths or worships was regarded as the sin of sins, yet its mind could not die. The Mysticism, with which in its old age it had sought to rise above itself, neither did nor could pass out of the minds of men. In part Christianity overcame it; but in part it infused itself into Christianity. And so strong is the impulse of the human mind to bring to unity all the insights and beliefs that have place in it, that the combination even of these opposites was soon attempted. No sooner had the great world-conflict been fought and settled, no sooner had history, in a Justinian, given its decisive answer to the endeavour of Julian, 


\section{ERIGENA: THE DIVISION OF NATURE}

than the Areopagite sought to give to a modified Neo-Platonism a standing within the church. And the Areopagite did not stand alone; he had many teachers and compeers-Monophysite monks, for instance, such as the real Stephen bar Sudaili and the phantom Heirotheus. But the passion of the conflict was still deep enough to sharpen the critical sense against books " unknown to Cyril and Athanasius." This ghost of Neo-Platonism, in its Christian dress, could but wander forward through the years, here and there (as in the case of Maximus the Confessor) speaking home to an elect heart, but by the great body of the orthodox misunderstood, suspected, or even condemned.

None the less, the combination was to take place. When Julian and Justinian and the Areopagite all were gone, and the northern races were seated beyond possibility of overthrow in the West-while Mercia still was disputing with her rivals the supremacy of England, and there were yet nearly forty years to the birth of Alfred the West-Saxon - there was growing up, probably in some corner of Ireland with a cloister school, the man who was to stand at the beginning of the greater labours of mediæval theology. But he was not to stand there merely as a churchman systematising canonic doctrine. He received into himself both the traditions now in question-the Christian theology of the Trinity and the Incarnation, and the Neo-Platonism contained in the mystical theology of Dionysius. These he welded into a system which sounds the note and contains the motives of each of the two great sides of mediæval thought-the mystic side and the scholastic; but which does much more. For Erigena was, in the strict sense of the word, a secular figure, a man who belongs to the ages; in him the great histories that had gone before him found a voice again; while with his endeavour to see the whole process of the world as a spiritual process, he from his ninth century may speak, as Noack points out, ${ }^{1}$ to the men of the nineteenth with their Hegel. Nature and history seem to have worked together in setting him in his fateful place. He was a Christian; by training, a theologian in the succession of Christian theologians. But by special kinship of nature he was fitted to receive, and, so far as was possible to a man who in his subtle and unusual genius must have stood almost alone, to introduce as a

1 In the Vorwort to his German translation of the De Divisione Naturae. 


\section{ERIGENA: THE DIVISION OF NATURE}

factor in the life of the West, that older theology to which God is all in all and the world an emanation from which the wise man will seek to return into God Himself.

For the mind of Erigena was dominated by that which was central to the logic of Neo-Platonism, and which in some form is central to all philosophy - the instinct for unity. And by that instinct in both its forms. As a philosophic or scientific instinct, it constrained him to view the world, and all the history and process of the world, as one-as one reality, issuing from one source, and in all its steps and stages remaining one. While as a religious passion, the passion for unity with God, it joined itself with the philosophic instinct to strengthen the demand that, as all things proceed from God, all things must in the end return to God.

But the instinct for unity has two ways of fulfilling itself. First; it may conceive the unity of all existence as a unity which mediates itself through diversity:- the unity which a system, for instance, has by reason of its highest principle, or which a process has by reason of the purpose that is realised in it. Or, secondly, it may conceive the unity of the real as the solid, undifferentiated unity which rejects from itself all manifoldness, all diversities, all distinctions. Of the two conceptions, the latter is the easier to form; particularly in early thought. Hence the man who is dominated by precisely the central impulse of all science and of all philosophy, often conceives the unity that he seeks as of the latter type. And from this, for the man of intellectual clearness and speculative courage, the consequences follow at once. The One is, and nothing else is. Then what is the manifold world of our experience? It is illusion. And if the inquirer is a religious man, he has to go a step farther. The welfare of the soul lies with reality. The duty of a true man, therefore, is to lift himself out of the illusion in which ordinary human life is spent. He must seek a new type of experience, a new form of consciousness, in which he enters into union with reality; in which he lays aside the finitude and manifoldness of human individuality, and without distinction or division of essence becomes one with God.

The key to Erigena's position is that he cannot enter clearly into the former of these two ways of philosophy, nor yet commit himself 


\section{ERIGENA: THE DIVISION OF NATURE}

unreservedly to the latter. Cannot enter clearly into the former: for he does not possess, in clear mastery, those "categories of organic unity" which enable human thought to retain all the manifoldness of the given world, and yet view that world as having the genuine unity of a system or process in which a single principle is manifesting itself, a single purpose being realised. Nor can he commit himself unreservedly to the latter. For his mind was not only subtle and acute. It was comprehensive also, delighting to traverse all the ranges of existence. And his spirit seems to have been affectionate; seems to have cast out many tendrils that clung about the things and persons of the manifold world; as frequently his parabolae with their keen eye for the face of nature, show, or the tender dedication subinde dilectissimo tibi, frater in Christo Wulfade, et in studiis sapientiae cooperatori, at the close of the De Divisione Naturae. But behind all such personal reasons stands the greater historical one-his inheritance of Christianity and of Christian theology. His vision of the Lord Christ taking upon Him the form of our mortal life, forbade him to dismiss the world of our present struggle as unreality and illusion.

So that Erigena's work was done under almost the greatest strain that can come upon a man in the courts of philosophy. By imperious necessities of thought within, by great histories without, he was compelled to be faithful both to the Many and to the One; and at the same time he was not clearly master of those categories which would have enabled him not merely to keep both the Many and the One, but to see each as necessary to the other. Hence he was in a continual struggle to keep faithful to his belief in the unity of existence, and at the same time to do justice to the diverse facts of that manifold world which was given to his singularly open-eyed and sensitive spirit. And what he built up under the pressure of that struggle was a system that has virtually all the great conceptions and tendencies and traditions of Alexandrian and mediæval thought woven into it. But Erigena did this as no mere eclectic, piecing together into an unstable structure materials afforded by the histories that he inherited. He was in himself a great speculative genius. And his spirit is in the system that he constructed. In all that age of great philosophies and theologies which reaches from Augustine to Cusanus, it has no equal 


\section{ERIGENA: THE DIVISION OF NATURE}

for its swift and free ascent of the secular consciousness to its home in God, or for the unfailing speculative passion with which it carries through the idea of the whole world as a procession from God. And it is the more remarkable as having taken form in the ninth century - as if, through grey and cloudy twilight of earliest morning there should break, for one fugitive moment and with the many-coloured radiance that speaks of evening rather than of morning, the flame of day.

The dialogue in which Erigena presents this system is long, complicated, self-involved. Continually the argument returns upon itself; yet not with the mere vexatious iteration of some of the later Schoolmen, but with an emphasis that always is new and with a "subtle flame" of speculation that maintains itself to the end. To this dialogue - the five books De Divisione Naturae-we must now turn, and attempt to follow in some systematic way the essential movement of its thought. ${ }^{1}$

First, in general terms, how did Erigena meet the situation just described? He keeps both sides, we must answer; and does this by means of an expedient that came to him from an earlier history.

First, he keeps the unity. To say this, indeed, is only to say that he is Erigena and a philosopher. Always he is asserting it, or taking it for granted, or labouring to reduce to it the stubborn opposites of the world. The very title of his book, which seems to indicate multiplicity, really points toward unity. The object of his thinking, the object of philosophy and theology, he calls Nature. But by Nature he means $\tau \dot{0} \pi \tilde{\alpha} v$, the totality of being viewed as one; and by the Forms into which Nature is divided he means the aspects which that one reality has somehow come to present. But secondly, as we shall

1 The references are to the edition of Floss (Migne, vol. 122 of the Latin Patrology).It is a question whether Erigena, with his passion for the point of view of eternity, did not (in speaking of the Word) frequently write ingenitus where Floss reads unigenitus.

Except at one or two points (where Erigena, in his scorn for the human body as contrasted with the angelic, is driven beyond his usual fine sensitiveness and allows the language with which he condemns the brute in man, itse'f to take on a touch'of brutality), I have made the translations very literal. This has been done in the hope of conveying a more accurate impression of the man himself in his ninth century thought. But in one way it is scarcely fair to him; the depth and acuteness of his mind would be better shown if his thoughts were turned into the present-day language of philosophy. 


\section{ERIGENA: THE DIVISION OF NATURE}

see more fully in dealing with the second and third Forms of Nature, he also keeps the manifold; though no man need imagine that the manifold which a mediæval theologian, and a disciple of the Areopagite at that, leaves standing, is quite the same as the manifold of ordinary experience.

But, retaining thus a manifoldness within reality, has he not shattered his own fundamental doctrine of the unity of Nature? The answer is, as indicated a moment ago, that he escapes the difficulty altogether, by bringing up a great distinction from that inheritance of theological tradition which was his intellectual field and home. This is the distinction between that which is and that which is not; and the consequent distinction between the methods of apprehending these two kinds of reality. The opening sentences of the De Divisione Naturae, in which Erigena chooses for the totality of things the great word Nature, show Nature as divided into the things that are and the things that are not:

Master.-Often-as I ponder, with such diligence of inquiry as my powers admit, upon the fact that the first and highest division of all things which can either be perceived by mind or transcend its reach, is into those that are and those that are not-there presents itself to me, as the general name

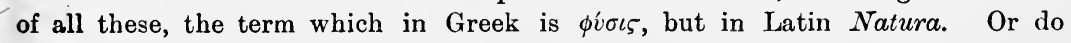
you view the matter otherwise?

Scholar.-Nay, I agree; for I, too, find it thus, when I enter upon the path of rational investigation.

Master.-Nature, then, as we have said, is the general name for all things which are and which are not.

That which is is the reality able to present itself in ordinary human experience; the reality apprehensible by human reason, and declared, therefore, by that reason to have existence. But there is a reality which stands high above all the categories of reason, and of which, therefore, reason can only say that it is not. This reality which is beyond the grasp of mind and can, therefore, in all thinking and speaking, be referred to only in negative terms of which the is not is the summing up, is the true and genuine reality. And with it, though human thought and speech can find no name for it except Nothing 


\section{ERIGENA: THE DIVISION OF NATURE}

and no description of it except that it is not, yet a union of the soul is possible; a union with which Erigena deals at length, but which we cannot consider at this point. Corresponding to this distinction within Nature is a distinction in theological method. There is, first, affirmative theology, which of the divine essence predicates what is; not meaning, indeed, that the divine essence is anything of that which is, but that all qualities and existences which have their source in it can be predicated of it. While negative theology denies that the divine essence falls in the province of that which is; i.e., of that which can be thought or spoken. ${ }^{1}$ You can say, for instance, that God is truth, inasmuch as $\mathrm{He}$ is the creator and original cause of that truth in which all things that are true participate. But, on the negative method, you deny that God is truth, because $\mathrm{He}$ is more than truth and is exalted above everything that can be thought or said, above everything of which it can at all be said that it $i .^{2}$ And of these two methods or procedures of theology, the preference must be given to the negative. For what the affirmative procedure does, is, as a working compromise, to effect a sort of transfer: it carries the methods of human thinking into a realm where properly they have no place. Categories like Essence, Wisdom, Truth, it applies where categories are not applicable. In strict propriety, it is only the via negativa that can be adopted in investigating the exalted and incomprehensible nature of God. If men must have a name for that nature, let them use the word that expresses the inability of thought to conceive it and of speech to utter it - the word Nihil. For God, being exalted above all that can be thought or uttered, can properly be affirmed only by the denial of

1 I. 13, 14. The argument of chapter 14 is one that has taken a great place in the history of theologia negativa. God is viewed as coincidentia oppositomum. Hence you must not attribute one side of an opposition or antithesis to God without the other. But human thought-so Erigena takes for granted, whatever deeper view may be implicit in him-has no conceptions which take up into unity both sides of these oppositions. Hence human thought is precluded from attributing qualities to God at all, and has to regard Him as altogether beyond the categories. It will be noted, that with these oppositions, e.g., Essence and Nothingness, Eternity and Time, Light and Darkness, Erigena does not regard the latter as merely a denial of the former, but views both as positive. Then since God is the source of both, affirmative theology must predicate both of Him; which can only mean that $\mathrm{He}$ is above both, and that therefore (as is noted in the text) the true procedure for theology is the negative procedure.

2 IV. 5. 


\section{ERIGENA: THE DIVISION OF NATURE}

all that is; and is better known by non-knowledge. ${ }^{1}$ Thus, then, the negative method avails us more than the affirmative, in our inevitable attempt to characterise the ineffable essence of God. For affirmative theology is a carrying over of qualities or predicates from the creatures to the Creator; but the denials of negative theology, moving far above every creature, are valid of the Creator in and for Himself. ${ }^{2}$ Hence it is that Erigena adopts the exhortation of the Areopagite to Timotheus his friend: "If thou art strong for journeying in the realm of mystic contemplation, forsake the senses and the operations of the intellect, and both the things of sense and the things that are invisible, and all that is and is not, and so far as in thee lieth be restored in non-knowledge to the unity of that which is above all essence and all science. For thus, in the immeasurable and unconditional passing of the soul beyond thyself and all things, forsaking all things, and from all things being set free, shalt thou ascend to the superessential ray of the divine darkness."

This division of Nature into that which is and that which is not, with the corresponding distinction between the methods of theology, is the expedient which sets Erigena free from his initial and fundamental difficulty. First, it leaves him free to assert the very highest doctrine of unity; a doctrine of unity which sets him at the side of Vedântist and Neo-Platonist. But secondly, it also leaves him free to give a place within reality to the manifold-the manifold of our experience, together with that higher system of forms and principles, of persons and energies, requisite for the explanation of our experience. And this simultaneous honouring of the two great and apparently antithetic necessities-the necessity for unity, asserted imperiously by the philosophic and theological intellect; and the necessity of recognising the actual manifold of our experience-can take place without fear of rational attack. For Nature as one (i.e., God as original source) is above all grasp of reason. If it be objected: Does

1 III. 20 and 22. Erigena feels so keenly that knowledge conditions and limits its object, that he is not content with denying that human reason can know God. He even constructs, under certain modifications, a doctrine that God cannot know Hiinself (II. 28). But in estimating the real significance of such a view, we must remember that for Erigena knowledge is defined by the ten Aristotelian categories.

2 IV. 5 . 


\section{ERIGENA: THE DIVISION OF NATURE}

not your retention of the manifold contradict your doctrine of unity? the answer is: You cannot say that, for reason cannot enter here; the nature of the One is not to be limited by the application to it of the categories. $^{1}$

Thus a "Division "-really not so much "of Nature," as of the aspects which Nature presents to minds like ours²--is effected. There is, first, Nature as One. It is above the categories; we cannot rationally comprehend it, though we must affirm its unity. There is, secondly, Nature as Manifold. This is the field wherein reason can profitably employ itself; and Erigena-as if rejoicing that his fundamental Mysticism is not after all to call him away from the courts of science to mystic quietude-flings himself upon it with all the powers of his subtle and eager mind and all the resources of his intellectual inheritance. As he considers it, he finds within it a great distinction. There are, first, the universals_eternal and energetic types; what Plato called Ideas, but Erigena calls primordial causes. Secondly, there are the effects of these causes, effects of which some at least are temporal and visible.

But even this is not the end. The instinct for unity still has a work to do, and here it is especially supported by the religious instinct. If it is a demand of reason that there should be a unitary source of all things, it is a demand both of reason and of religion that there should be a unitary end of all things. So that the final Form of Nature is that in which there is no more procession-no more forth-going-of creatures in classes and kinds, but all things, in quiet, rest in God as an undivided and unchangeable One. ${ }^{3}$

Thus the "Division of Nature" comes at last to be fourfold. First, there is Nature as One-Nature as creating, but not created,

1 It is interesting to compare the somewhat similar situation in Kant. Moral reason asserts a categorical imperative. And that assertion, so Kant thinks, the scientific reason cannot challenge, because scientific reason cannot enter into the realm of noumena.

2 Cf. infra, pp. 304-397 and 314-316 (especially 315).-At the beginning of the third Book, the second Form of Nature is referred to as "the second way of viewing universal Nature, and, so to speak, its form or appearance."-In Spinoza, on the interpretation of those who in dealing with the definition of "Attribute" (Eth. I. def. IV.) emphasise the tanquam, there is a similar situation, arising out of similar logical motives.

3 II. 2. 


\section{ERIGENA: THE DIVISION OF NATURE}

God as the original source of all things; secondly, the aboriginal causes-Nature as created and creating; thirdly, the effects of theseNature as created, but not creating; fourthly, Nature as One again, when all process or emanation from the original One has returned to its source, and God is all in all.

To the consideration of these four Forms of Nature, the De Divisione Naturae is given. Of the first, as it is in itself, there is, of course, nothing to be said, except in the way of amplifying the negative position already indicated. This Erigena specially does in the first Book, a great part of which is occupied by an extended proof of the inapplicability of the ten Aristotelian categories to God. The Book concludes by insisting once more upon the greater truth of the negative theology. "And this is the Confession, prudent and catholic and for our salvation, which we are to make concerning God:- that we may first, in the affirmative way, using names or words, predicate all things of Him, not properly, but by a certain transfer; but that all these may again with full propriety be denied of Him according to the negative way. For it is more correct to deny, than to affirm, that God is anything of that which is predicated of Him." " . . . Of God nothing can properly be predicated, because $\mathrm{He}$ is above every thought, above every characterisation in form of sense or intelligence; better is He known through non-knowledge; His absence of knowledge is the true wisdom; more truly and more credibly is He denied in all than affirmed. For whatsoever thou deniest of Him thou deniest truly; but in no wise does that which our reason establishes about Him stand fast in reality. If thou provest (approbaveris, imaginest thyself to have proven) that $\mathrm{He}$ is this or that, thou shalt stand in the end convicted of falsehood, because He is nothing of all those things which are, or which can be said or thought. If, however, thou declarest that $\mathrm{He}$ is neither this, nor that, nor any definite thing (nec hoc, nec illud, nec ullum), then thy truthfulness shall be made manifest because $\mathrm{He}$ is nothing of all those things which are and which are not. To him no man can draw near, unless first, making strong the path of the soul, he

1 I. 76.-Erigena likes to call affirmative theology cataphatic, negative theology apophatic. 


\section{ERIGENA: THE DIVISION OF NATURE}

leaves behind him all the senses, and the activities of the understanding, and all the things of sense, together with the whole of that which is and which is not, and so far as in him lies is restored in non-knowledge to unity with Him who is far above every essence and all thought; for whom neither reason nor thinking is suitable, nor can $\mathrm{He}$ be uttered or understood, nor is there for Him name or word."1

And yet something positive must be said about the first Form of Nature. For Erigena is simply not capable of affirming a One above the categories, and a Many subject to the categories, and then merely leaving these side by side, with the statement that nothing can be said affirmatively of the One, and that therefore the only thing for us to do is to describe the Manifold as we find it. So that, although the first Form of Nature is above the categories, yet Erigena does after all make it an object of positive philosophical investigation; he considers, namely, its outgoing or procession into the lower Forms, and so gives us a view of the universe of particular beings, as unfolded from an original unity.

That is to say, Erigena turns to affirmative theology. The very next sentence after the passage just quoted, goes on: "But, on the other hand, as we have often said, without precisely contradicting reason, all the things which are, from the highest to the lowest, can be predicated of God, in the way of a certain similarity, or dissimilarity, or contrariety, or opposition, since all the things which may be predicated of Him have their source in Him." Then the second Book makes a formal transition to the theology of affirmation, in which, in our reflective consideration of the universe, we may by a sort of transfer apply the terms and methods of our human science to God, " since everything which has its being in Him and from Him, may with piety and reason be predicated of him." ${ }^{2}$ Later in the second Book, the same transition is again indicated; for while in the $D e$ Divisione Naturae there is an orderly plan and advance, yet the book is like a gleaming web, in which all the strands are present at the beginning and continually are reappearing. So that after dealing in the earlier part of the second Book with the procession of the primordial causes from God, and with the nature of man,--drawing 


\section{ERIGENA: THE DIVISION OF NATURE}

his doctrines with inimitable exegesis from " divinissimus propheta, Moisen"1-he turns back to the inapplicability of the categories to God; and to God's non-knowledge which is "ineffable understanding," the "true and highest wisdom" ; then returns to the doctrine of the Trinity thus: "Let us now turn again to theology, which is the first and chiefest part of wisdom. Rightly is it called so, because it is concerned either solely or principally with the contemplation of the divine nature. It falls into two parts, an affirmative and a negative,

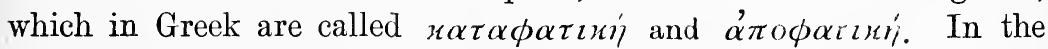
first Book we dealt with negative theology, denying upon assured grounds that the ten categories-together with all genera, forms, numbers, and accidents-can properly be predicated of God. In this present Book we have also proceeded according to the negative way, as the order of our problem demanded; and have taken up the position, that God in His essence understands nothing of all that, which is and is not, because He transcends every essence; that He absolutely does not know what $\mathrm{He}$ is (since $\mathrm{He}$ is in no wise determined or conditioned), or of what quantity or quality $\mathrm{He}$ is (since no such determination attaches to Him and $\mathrm{He}$ is in nothing to be understood); and that $\mathrm{He}$ in Himself absolutely cannot be comprehended in that which is and that which is not:- - a sort of non-knowledge which stands high above all knowledge and understanding. But now let us attempt to gain an insight into the other part, into affirmative theology, under the leadership of Him, who is sought and seeks to be sought, who comes to meet the souls that seek Him, and desires to be found. This part of theology it is which, with regard to the divine nature, considers what may with a certain propriety be brought forward, and be understood by reason if it go prudently."3

We have already noted the forms or stages under which Erigena considers the procession by which the one eternal Nature gives rise to a manifold reality. The first stage in the forth-going process-what Erigena calls the second Form of Nature-contains a multitude of existences, the causae primordiales. These are perfect; are purely

1 II. 15 .

2 II. 28.-Ipsius enim ignorantia incffabilis est intelligentia. . . . Ipsa itaque ignorantia summa ac vera est sapientia.

3 II. 30 . 


\section{ERIGENA: THE DIVISION OF NATURE}

intelligible, unmixed with space or time; are at once creative energies and the archetypes after which the things of this world are found;-in a word, are Platonic Ideas. Yet Erigena is never weary of insisting that this second Form of Nature is a unity. That is to say, he really views it as a system-a system of intelligible forms, a

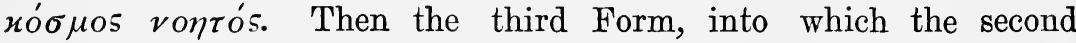
proceeds, contains the actual things and beings of this present world.

We shall best understand Erigena's position in this-shall best set before our minds both the difficulties that he faced, and the solutions that he found for them-if we turn back for a moment to Neo-Platonism, and alongside the solutions that Plotinus worked out for the difficulties which beset him, place the solutions that Erigena worked out for precisely the same difficulties. The One of Plotinus, like Erigena's first Form of Nature, is absolutely a unity; it rejects from itself all diversity and manifoldness. And it is absolutely transcendent; so that reason can attain to no comprehension of it. Yet the manifold world of our experience is left standing; and, since dualism is intolerable, that absolutely transcendent principle is necessarily regarded as the source of it. But then arises at once the problem: How can the One remain in its absolute transcendence and absolute self-containedness, and yet give rise to this present world? The steps in Plotinus' attempt to solve this problem we have already had to consider. ${ }^{1}$ First, he has two devices for enabling him to regard the One as giving rise to something beyond itself, and yet as remaining in its absolute unity. One of these devices consists in metaphor; the procession of some further reality from the One is emanation, which leaves the source precisely what it was before-as fragrance does the flower from which it comes, or light the flame, or cold the snow. The other is that most ingenious of logical devices, the conception of oneended relationship: "It (the One) is by no means that of which it is the principle." Thus the passage is made from the One to that which, in Plotinus' system, corresponds to the second Form of Nature in Erigena's; to the voṽs. 'This is viewed as at once one and many. It is a иó Ideas or archetypes after which the things of the visible world are

1 Supra, pp. 142-144. 


\section{ERIGENA: THE DIVISION OF NATURE}

made; i.e., at this point Plotinus weaves into his system the Platonic theory of Ideas. And as the vois is an emanation from the One, so it is itself the source of a farther emanation, and thus we are led at last to our present world.

But such a view involves difficulties, of which we must here notice three. (1) There is the difficulty in deriving the vov s from the One at all. (2) There is a difficulty in what may be called the internal constitution of the vors. As an emanation from the One it also is One; but toward the world-as containing the Ideas or archetypes of the world-it is many. But the two sides of the conception are not adequately held together. The voiss is a one; and it is a many; but what the principle or energy of synthesis is, which thus enables a one to be at the same time a many, Plotinus does not and cannot explain. (3) The difficulty in the relation of the One to the vovs recurs in the relation of the voiss to the world below it. How does the voñs go beyond itself to give rise to the manifold world of our sense-experience? This difficulty is almost the same as that in Plato's earlier Idealism with regard to the relation of the Ideas to the manifold things of sense.

These difficulties are all in a sense contained in the first. Any adequate solution of it would almost certainly involve the solution of the others. But precisely that first difficulty it is which is absolutely hopeless. When God or reality is defined in the Neo-Platonic way as absolutely one, absolutely self-contained, absolutely transcendent, there is no possibility whatever of advancing to a manifold world. You are shut up to the position of the Vedântist and of Parmenides. There simply is no such thing as a manifold world. Belief in it is an illusion; and a wise man's business is to free himself from the illusion.

But, as we have seen, ${ }^{1}$ Plotinus could not take up that position. He cannot deny the existence of the manifold world, and therefore is compelled to attempt in the way just noticed a derivation of it from the One. But the derivation is altogether unsatisfactory. The metaphors do not help us; metaphors may illustrate arguments, but are not themselves arguments. And the conception of a one-ended relationship must be rejected as contradicting the very idea of 
relationship. What really lies behind these devices is the fact that in Plotinus there are two types of thinking: the mystic thinking to which reality is an absolutely self-contained One admitting no multiplicity; and the thinking which views the One as the source of the manifold world. The same two types of thinking are in Spinoza; we have already had to study the way in which he makes the transition from the one to the other-the way in which Spinoza the Mystic, with his One Substance that can have no determinations, passes over into Spinoza the Pantheist to whom that indeterminate One has become the self-determining energy of an orderly and systematic world. ${ }^{1}$ One might almost say that the chief difference between the two is that in Plotinus the Mystic predominates, in Spinoza the Pantheist. And the sarne two types of thinking are in Erigena; only with him it is hard to say which predominates. In fact, he is completely in earnest with both. On almost every page can be found the ideas which represent the two sides: the idea of God-the first Form of Natureas absolutely transcending our knowledge, and as that absolute unity which repels all diversity; and the idea of God "pouring Himself forth," and so giving rise to the various orders of existence which make up the universe. And he does not seem to have seen how incompatible these types of thinking are. There are, indeed, indications of the gulf and attempts to bridge it. ${ }^{2}$ But upon the whole the battle never is fought out. On the contrary, Erigena may be said to give himself completely to each of the two sides. And for this he ought not to be condemned as a man involved in mere self-contradiction. For, in doing it, what he really does is to prophesy the Idealism which

\section{Supra, pp. 165-175.}

2 Here and there are statements, for instance, which remind one of the device of Plotinus: It is by no means that of which it is the principle. The divine wisdom, says Erigena, "without measure is the measure of all, without number is the number of all, without weight is the weight or order of all" (III. 16). To the "grounds" of things-the primordial causes-he applies the distinction of Dionysins: "first they are, and then they are grounds" (II. 36). Again he frequently avails himself of a distinction that reminds one of Mr. Spencer-the possibility of knowing that something is, while it remains quite impossible to know what it is (e.g., III. 28). Sometimes, again, he declares that it is a "mystery"; or appeals to the darkening of our minds since the fall. But upon the whole, as is said in the text, he simply leaves the two types of thinking side by side. Indeed, he does this in set phrase: "the ineffable manifoldness of the divine unity-for God is in Himself manifold unity." (. . . de ineffabili divinae unitatis multiplicitate-Deus est enim unum multiplex in seipso-III. 17). 
stands above both Mysticism and Pantheism, being able by its organic categories, to do justice alike to the unity of the divine nature and the manifoldness of the world, alike to the transcendence and the immanence of God. In accepting each side as true he really recognised that truth was greater than either. ${ }^{1}$

The conception of the procession or forthpouring of God, as the source of the universe of creatures, is everywhere in Erigena. We must be content, however, with two passages; two great passages one would call them, were it not that the De Divisione Naturae is crowded from beginning to end with such passages. One occurs about midway in the third Book. God, he says (following Dionysius), cannot be called this or that, because He is all and in all. Then he goes on to trace the process in which God goes beyond Himself and yet remains Himself. "Descending first from the superessentiality of His nature, in which He can but be called Non-Being, $\mathrm{He}$ is created of Himself [undergoes a creation at His own hands] in the primordial causes, and becomes the beginning of every essence and of all life, of every understanding, and of all things that enlightened contemplation perceives (gnostica considerat theoria) in the primordial causes. Then, descending out of the primordial causes, which occupy, as it were, a middle station between God and the creature, that is, between that ineffable superessentiality which stands high above every thought, and the revealed Nature which is essentially cognisable for pure spirits,

1 It may be advisable-especially in view of the loose and irresponsible way in which the term "Pantheism" is frequently used-to point out once more the exact relation of the three types of thought referred to in the above paragraph. Pantheism $i=$ the extreme opposite of Mysticism; while Idealism, when it is really dominant and not simply a servant of some other view, does justice to the truth of both. Mysticism sees reality as an incommunicable One before which all the apparent things of our experience fade into nothingness. Pantheism (of which Spinoza's "second metaphysic" is a type), on the contrary, views God as unfolding Himself into a world of particular things and facts, all of which therefore are real with the reality of God, but none of which can be called "individuals," since each is simply a mode of the one divine Substance. Mysticism, in a word, is the theology of absolute transcendence, Pantheirm the theology of absolute immanence. While Idealism doe justice to both the two sides by viewing God as a selfdetermining and self-communicating spirit-Himself a perfect individual, imparting Him-elf and so giving rise to imperfect or "created" individuals. Again, Mysticism is negative theo'ogy; while Pantheism and Idealism, though in very different ways, are affirmative theologies. In dealing with the first Form of Nature, Erigena is a Mystic; in dealing with the second and third Forms, he might almost be called a combination of Idealist and Pantheist; and we shall have later to ask whether in dealing with the fourth Form, he returns to the Mysticism of the first. 


\section{ERIGENA: THE DIVISION OF NATGRE}

he 'becomes' in the effects of those causes, and is made manifest in His theophanies. Thence, through the manifold forms of those effects, He proceeds, even to that last order of collective nature, in which bodies are contained. And as in this order he goes forth into all things, He makes all and becomes all in all, and returns into Himself by calling all things back into Himself, and while $\mathrm{He}$ comes to be [enters upon conditioned existence, as one might say in the terminology of a modern school] in all things, He does not cease to be above all. All things $\mathrm{He}$ makes out of nothing, ${ }^{1}$ inasmuch as out of His superessentiality $\mathrm{He}$ brings forth essences; living beings out of His exaltation above life; intellects out of His transcendence of the intellect; out of the negation of everything which is and is not, the affirmation of all that is and is not. By this also we are most clearly taught the return of all things into the cause, out of which they proceeded, when all things turn back again into God, as air into light, when God will be all in all; not, indeed, as if God were not even now all in all, but because, since the transgression of human nature and its banishment from its seat in Eden-that is to say, from the height of the spiritual life, and from the apprehension of clearest wisdom-into the profoundest deep of ignorance, no one save by divine grace is enlightened, or is able-rapt with Paul to the height of the hidden things of God-to discern with the intent gaze of true understanding how God is all in all; for the cloud of fleshly thoughts and the gloomy twilight of vain imaginations lie between, and the penetrating genius of the soul, weakened by unreasoning passions and baffled by the splendours of transparent truth, expends itself upon the accustomed shadows of the corporeal world. For it is not open to us to believe that the heavenly essences, who never have left their state of eternal blessedness, can recognise in the whole of creation anything else but only God Himself, since they, lifted high above all sense and thought, see all things in God and in the primordial causes, without needing any

1 For this "nothing," it will of course be understood, Erigena has a meaning. The "nothing" out of which the world is made, he proves (III. 20-23) to be the superessential God Himself. For" all things have their becoming from God and through God and in God"; and if God is to be viewed as cause and the world as effect, then "there does not pass over from the cause into its effects anything which is alien to the true and proper nature of the cause." 


\section{ERIGENA: THE DIVISION OF NATURE}

work of nature for the knowledge of truth,-for they alone enjoy the ineffable grace of the eternal light." 1

The other, and more extended, of the two passages occurs earlier in the third Book. Erigena is dealing with the "participation" which exists among the orders of natural being. But before taking this passage we should note the express definition of "participation" given in another chapter. All things that are, says Erigena-following "that supreme theologian, Dionysius the Areopagite, illustrious bishop of Athens"-all things that are and all things that are not, are to be understood as nothing other than participation in the divine essence. This participation is itself nothing other than the reception or assumption of the essence which is participated in; and such reception implies, or rather is, the "pouring out of the divine wisdom which is to all things their substance and their essence and whatever under the form of nature is to be perceived in them." ${ }^{2}$ But in the passage which we are now to consider Erigena is thinking of that participation as the principle of the ordering of the whole universe. Each order of natural being participates in that which is above it and is participated in by that below it; except that God, who is highest, is participated in, but does not participate; while "bodies," which are lowest, participate, but are not participated in. From their original ground in the divine Wisdom, the orders of being descend in a series of natural gradations ; among their "participations" the all-creative wisdom "has established wonderful and ineffable harmonies by which all things are brought to the accord and friendship, or to the peace and love, or to whatever else be the true name for this unifying of all things." But what can this "participation" be? It is nothing other, is the answer, than the derivation of a next-following essence from that which precedes it, and the bestowal of being from a first to that which stands next to it. And then Erigena goes on to show how, through such bestowal, the orders of the universe have their being. As a river

1 III. 20.

2 III. 9. - The Master goes on to call the Scholar's attention to the opinion of Dionysius de processione Dei per omnia, et mansione in seipso, in a letter to Titus the priest who had asked what the house of Wisdom is, and what its mixing-bowl and its meat and drink. 
streams from its source, and its waters for ever and, without loss of continuity make their way downward through the longest channel, so " the divine goodness, and essence, and life, and wisdom, and all that in the source of all exists, pour forth, first in the primordial causes, and make these to be; and then hasten down, in some ineffable way, through the primordial causes into the effects of these, through the self-harmonious orders of the universe, always flowing down through the higher to the lower; and return by the most secret pores of nature, and by the most hidden path, to their source again. From that source is every good thing, every essence, all life, all sense, all reason, all wisdom, every genus, every species, all beauty, all order, all unity, all equality, all difference, all place, all time, both everything which is and everything which is not, both everything which is thought and everything which is perceived by sense and everything which is above sense and thought. The immutable motion in itself of the highest and triune and sole true goodness, and its simple multiplicity, and its inexhaustible pouring forth from itself, in itself, to itself, are the cause of all things, nay rather, are all things. For if the being thought of all things (intellectus omnium) is all things, and if the divine goodness alone thinks all things, then that divine goodness itself is alone all things, because it is the sole gnostic power which knew all things before they were all things, and knew all things not outside of itself-for outside of itself there is nothing-but has all things within itself. For it encompasses all things, and nothing is within it, in so far as it is true, but itself, because it alone is true. The other things which are said to be, are its theophanies, which truly subsist in it. And so God is everything which truly is, because He Himself makes all things and becomes in all things, as saith St. Dionysius the Areopagite. For everything"-here Erigena exhausts the power of metaphor in insisting that the world which is known is the manifestation of the God who cannot be known-" everything which is thought or perceived by sense is nothing other than the appearance of Him who does not appear, the manifestation of the hidden, the affirmation of the denied, the comprehension of the incomprehensible, the utterance of the ineffable, the approach of the inaccessible, the apprehension of the unintelligible, 


\section{ERIGENA: THE DIVISION OF NATURE}

the body of the incorporeal, the essence of that which is above essence, the form of that which has no form, the measure of the immeasurable, the number of the innumerable, the weight of that which is devoid of weight, the coming into gross matter of the spiritual, the visibility of the invisible, the possession of place by that which is beyond place, the taking on of time-form by that which is above time, the defining of the infinite, the circumscribing of that which cannot be compassed, and whatever else is thought or comprehended by pure intellect, or cannot be held within the bounds of memory, or escapes the penetrating insight of the soul."1 Then Erigena goes on to show, in the most interesting way, that we men have in our own nature as intelligences, an example of precisely such an activity of self-manifestation. Alone, invisible, absolute in itself, our thought is yet able to go forth from itself, and to incorporate itself in sounds and signs, and to enter into the depth of others' hearts, and mingle itself with other minds, and become one with that to which it is joined-and yet it remains always itself, and in uniting itself with others does not relinquish its own simplicity. But this brings us to an aspect of Erigena's thought (his Idealism) which we are not yet in position to discuss. What we have at this point to consider is something very different: namely, that when Erigena proceeds to work out his view of the universe in its descending scale of existences as arising from an outflowing, a pouring forth, of itself on the part of the divina bonitas, he is in much better position than Plotinus. His view of the absolute unity and transcendence of God places him, at the beginning, in the same logical situation as Plotinus, and with the same difficulties to face. But he inherited that which Plotinus did not; the tradition of Christian theology. And this in a form peculiarly favourable to his endeavour; for the theology to which he turned by affinity of soul, was that last great world-labour of the Greek spirit, the theology of the East. True, he quotes continually from the Areopagite and from Maximus the Confessor; but he constructs no fantastic hierarchy; a singularly clear and piercing reason guides him, even when he is denying that reason can know ultimate reality. True, again, he could not live in the West and escape Augustine's influence; yet he is able to deal critically even with

1 III. 4. 


\section{ERIGENA: THE DIVISION OF NATURE}

Augustine. But the man to whom really he reaches his hands across the ages is Origen. And the theology which really had power over his mind was that theology whose central and determinative conception is the idea of the divine nature manifesting itself in the Word. This theology of the Logos and the Trinity it is that guides Erigena in this greater half of his thought which sees the incommunicable One as the God who goes forth from Himself, communicates Himself, and gives rise to a universe which in the ordered scale of its existences is full of harmony and beauty, and in its natural arrangements testifies of spiritual truths. So that Erigena is able to bring to the difficulties that beset him and Plotinus alike, a solution which tends as truly to be concrete as that of Plotinus to be abstract. Where Plotinus is compelled to deal in abstract Ideas, Erigena deals in living cnergies, living powers, living affections. The system of Erigena comes, in fact, to be a Neo-Platonic framework filled with Idealistic content.

The second Book is formally given to the consideration of "the procession of the creatures from the first and unitary cause of all things through the primordial essences (which, before all things, are established by it and in it and through it) into the diverse classes, and forms, and numbers, of things, to infinity."' At the same time-so the Master warns the Disciple-we shall find in the course of that discussion many a thing introduced about the return of the creatures to their beginning and goal; for the procession and the return of the creatures are so intimately connected as to appear inseparable; about the procession nothing worthy or reliable can be advanced without at the same time considering the return of the creatures and the final unifying of all things. Then the Master begins the discussion of the first stage of the outgoing of the divine nature in this way: "As the second Form of universal Nature, there appears (enitet, shines forth), as was said above, that which is created and creates, and which according to my belief is to be understood as consisting only in the primordial causes of things. These primordial causes of things are called by the Greeks $\pi \rho \omega \tau$ ó $\tau v \pi \alpha$, that is, primordial patterns, or $\pi \rho o o \rho i \sigma \mu \alpha \tau \alpha$, that is, predestinations or determinings (definitiones); or again, $\theta \varepsilon \tilde{\varepsilon} \alpha \quad \theta \varepsilon \lambda \dot{\eta}^{\prime} \mu \alpha \tau \alpha$, that is, divine volitions; and also $i \delta \varepsilon^{\prime} \alpha \tau$,

1 II. 2. 


\section{ERIGENA: 'THE DIVISION OF NATURE}

that is, kinds or forms in which the unchangeable grounds of all things to be created, were already present. Concerning these we shall speak more in detail in the course of our work, and bring forward testimonies from the holy Fathers. Not wrongly, however, are they called by those names; for the Father, that is, the beginning and origin of all things, constituted already in His Word (namely, in the onlybegotten Son) the grounds of all things which were to be created, before he constituted them into genera, and species, and numbers, and differences, and all those other things which in created Nature either ean be seen and are seen, or on account of their loftiness cannot be seen, and are not seen, but none the less are."1

The original forms, then-the beginnings, the causes, the Ideasof all things, the Father constituted in the Son. And constituted them eternally. "What is to be gathered," Erigena asks, "from that word of the theologian: In the beginning God created? Art thou to understand from these words, that the Father first begot His Word, and then made the heavens and the earth in Him? Or has He begotten His Word eternally, and in Him eternally made all things, so that the procession of the Word from the Father, through begetting, in no wise goes before that procession of all things out of nothing which is accomplished in the Word through ereation? Or, to put it more plainly: have the primordial causes not always been in the Word of God in which they have been made? and was the Word when as yet the causes were not? Or are they co-eternal with Him, so that the Word never existed without the eauses which have their ground in Him? and is then that which is said of a precedence of the Word to the eauses grounded in Him, spoken altogether in the sense, that the Word creates the eauses, and they by the Word and in the Word are created?" The decision is in favour of the latter view; "for," as the Disciple" says, "I do not see how a begetting of the Word from the Father can precede in time the ereation of all things from the Father in the Word and through the Word. Rather I must believe that the begetting of the Word and the ereation of all things in the Word, are co-eternal, since no one can be right in believing that in God there is anything accidental or any temporal motions or processions. . . . Since to

1 II. 2 


\section{ERIGENA: THE DIVISION OF NATURE}

God it is not accidental to be the Beginning, therefore He was never without that of which He is the beginning."1 And the primordial causes which are thus eternal in the Word are likewise, in that Word, both one and many, both a unity and a manifold. A passage in the third Book in which this unity-in-diversity of the primordial causes is set forth, is specially interesting both for itself and for the argument which it concludes. ${ }^{2}$ The Disciple is in a perplexity: in the unbegotten Word, or Wisdom, of the Father the primordial causes are eternal; in that Word or Wisdom, too, all things that proceed are eternal; then how can the world have been created, as the church teaches us, out of nothing? For how can anything be eternal, which was not before it originated? And how can that be in eternity which begins to be in and with time? The Disciple, following a line of thought which is present in Plato and Aristotle, is inclined to take refuge in a theory of "formless matter." The primordial causes are eternal in the Wisdom of the Father; but the formless matter in and through which those causes pass over into their effects-i.e., into the genera and species of which the world is made up-is not thus eternal in God, and is not to be numbered among the active "causes." But Erigena sees clearly that if such formless matter plays a part in the constituting of the world, it must also be numbered among the causes which are eternal in God; and points out the contradiction in the position of the "secular philosophers" who make formless matter a principle outside of God and co-eternal with Him. He gives them credit for taking up such a position out of their high conception of God, as a being who can have no connexion with formless matter. But his own vision is more comprehensive and more daring: both the formlessness of things, and their forms, with everything, whether essential or accidental, which those forms contain, are created of the one All-cause. From the one universal ground or source everything which is, and which is not, flows forth: whether in the primordial causes which, at once and all together (semel et simul), eternally are made in the only-begotten Word of God; or in the formless matter irom which the primordial causes have taken occasion to appear in visible creation; or in the effects of those primordial causes--effects

1 II. 2 ?. 2 III. 5-9. 


\section{ERIGENA: THE DIVISION OF NATURE}

in which this world from its beginning to its end runs its course in natural order under the guidance of divine providence. But this only shifts the Disciple's perplexity into another quarter. How can the world be eternal in God when Eternity and Becoming stand opposed? That which becomes stands in antithesis to that which is eternal: how, then, can the world be at once eternal and yet in process of becoming? In reply it is pointed out that in God there is nothing accidental. Therefore, if $\mathrm{He}$ is Creator, $\mathrm{He}$ is not so accidentally; it must be of the essence of His nature to be Creator; and, therefore, $\mathrm{He}$ is Creator eternally. That which is eternal, therefore, and that which has come to be, are not diverse, but are one and the same; in the Word of God, the universe is eternal, and yet it is at the same time a process of becoming. ${ }^{1}$ Then Erigena sums up the argument with a statement to this effect.-The grounds of all things, so far as they are understood in the superessential nature of the Word, are eternal. For whatever exists substantially in the divine Word, just because it is nothing other than the Word itself, must necessarily be eternal. So, then, the Word itself and the unitary and yet manifold highest ground of the whole created universe are one and the same.

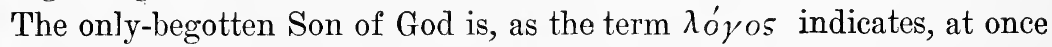
Word and ground and cause: the Word, for through Him the Father spoke the becoming of all things; the ground, for He Himself is the first exemplar [the Idea] of the whole visible and invisible universein Him the Father saw all that He willed to come to be, before it had

1 Cf. III. 16. “. . . all things visible and invisible, eternal and timeless, and eternity itself, and time, and places, and distances, and all that is named under the categories of substance or of accident, and in general terms what things soever the whole created universe contains, are at once, in the only-begotten Word of God, both eternal and made. In them neither does the eternity precede the becoming, nor the becoming the eternity; the eternity is created and the being created is eternal in the dispensation of the Word. For all things which in the order of the ages seem to come temporally or spatially into being through generation have eternally been made, all together and at once, in the Word of the Isord. It is not to be believed that they first begin to be when their arising in this world is perceived." Substantially they were always in the Word of the Lord ; and their arising. and perishing in the order of space and time through generation, that $i$, through the reception of the accidental, was always in the Word of God, in which that which is to become already has become. The divine Wisdom includes all times, so that everything which in the nature of things has a temporal origin, in it precedes and eternally subsists. For it without measure is the measure of all, without number is the number of all, without weight is the weight or order of all; nay, is time and age, is past and present and future." 


\section{ERIGENA: THE DIVISION OF NATURE}

yet become; the cause, for the occasions to all things subsist eternally and unchangeably in Him. And since the Son of God is thus Word and ground and cause, it is not inappropriate to say: the unitary and yet in itself infinitely manifold creative ground and cause of the whole created universe, is the IVord of God; or conversely, the Word of God is the unitary and yet in itself infinitely manifold creative ground and cause of the created universe. Unitary (simplex), because the totality of all things in Him is indivisible and inseparable; assuredly the Word of God is the indivisible and inseparable unity of all things, because He Himself is all things. Manifold, however, it may also without incorrectness be called, because it pours itself out to infinity through all things; and this outpouring is itself the subsistence of all things, for "it reaches from end to end sweetly and strongly ordering all things" (as is declared in the Psalm: velociter currit sermo ejus). The Word remains comprehended in itself and unitary, because in it all things are one. While it remains in itself as something complete, and more than complete, and separate from all things, yet it extends itself into all things, and that extension of itself is all things. The outpouring, or extension, or "running" of the Word goes [logically] before all things, and is the cause of the existence of all things, and is all things. For, as Erigena emphatically says, there could be no more despicable and pitiable death of the rational soul than even to think, concerning the All-creator, such an abominable monstrosity as that there is a space or time (or, he might have added, matter) already prepared out into which the Word of God in its creative activity proceeds.

This belief that God eternally constituted the primordial causes in the Word, and that in the Word they are one, stands central to Erigena's theory of the world and its derivation from God. He does not deal explicitly with the relation of the Word to the original and ultimate God, nor with the question whether that ultimate God has manifested or communicated Himself in the Word. Such a question could but be ruled out of court by a theologian who with regard to the first and ultimate God follows the via negativa. ${ }^{1}$ So that with regard

1 After the formal transition from negative to affirmative theology in the passage quoted above (II. 30 ; see p. 283 supra), Erigena turns directly to the doctrine of the Trinity and goes on to say that the Father may not inappropriately be identified with the 


\section{ERIGENA: THE DIVISION OF NA'TURE}

to the three difficulties of Plotinus mentioned above, we must say that the first stands also for Erigena; stands, in fact, for all negative theology whatsoever. At the same time it should be pointed out that Erigena, inheriting and employing in the way just noted the Logosdoctrine of Greek theology, needed but to go one step farther than he actually did-needed but to view the Logos as not only the principle of unity of the second Form, but as also its principle of relation with the first-in order to overcome the negative theology altogether. But that was not to be expected. With Frigena-as with many of the greatest mediæval theologians-to give up the negative theology would have'been to give up half of his soul. But when once he has passed from the first Form of Nature to the second, it illuminates the whole way for him. It enables him to solve at once what we have called the second difficulty of Plotinus; for he can view the causae primordiales, the Ideas, as one in Christ; in Him the ideal world, the second Form of Nature, consists; $\mathrm{He}$ is the living principle of synthesis in which the primordial causes are at once many and one. ${ }^{1}$

"cause of causes." There are other passages which seem to touch upon this; but they really deal with the inner relationships of the Trinity. Eckhart's problem of the relation of God (the Trinity) to the Godhead-which is precisely the problem at issue here-Erigena does not face. Indeed, as already has been pointed out, his treatment of the first Form of Nature, if it be allowed to stand, absolves him from the obligation to deal with it.

1 How this can be, Erigena bluntly confesses that he does not know. "How all things have their ground in the Word of God, let him explain who can. I eonfess that I do not know. And I am not ashamed not to know, when I hear the A postle say Qui solus habes immortalitatem, et lucem habitas inaccessibilem,-just as if he were aiming from far at our present investigation."' (III. 16.)

What is really behind such a statement is the fact that Erigena is not able to use the organic categories to show how a spiritual system is botl a many and a one. And a still graver evidence of the same fact is the way in which Erigena at times almost loses the manifoldness of the Ideas or primordial causes in their unity. "The grounds of the things which God has created in Himself (i.e., which the Father has created in the Son) are"-so Erigena takes for granted in the course of one of his arguments-" one in Him without division; they admit no defining of the proper substance through proper differ. entiae or through accidental determinations, for it is only in their effects, not in themselves, that they suffer these." (II. 28.) "In themselves the first eauses are one, and simple, and through no known order determined or separated from one another; such determination or separation they undergo in their effects. Even as in the unit, while in it all the particular numbers by one principle subsist, yet no single number is distinguished from another, since in it they are a unity, and a simple unity, and not a unity compounded of many members (for while out of the unit all the multiplication of the numbers proceeds to infinity, yet the unit is by no means composed of the manifold numbers which proceed from it, as if by a sort of counting the-e together into one):-even so the primordial causes, while they are understood as contained in the principle of all things, that is to say, in the only-begotten (al. unbegutten) WVord of God, are a simple and undivided unity; as 


\section{ERIGENA: THE DIVISION OF NATURE}

And it likewise places, within his reach a solution of what was noted as the third difficulty of Plotinus. The existence of the primordial causes in the Word makes it easy to view them as having a living and a creative energy, such as enables them to proceed beyond themselves and give rise to the particular things and beings of our present world. Or, rather, it is the Word itself that in them proceeds to another stage in its outpouring of itself, ${ }_{1}^{1}$ and gives rise to another order of natural existences-to what Erigena calls the third Form of Nature.

At the close of the second Book there is a passage which sums up Erigena's view of the second Form of Nature as a world of ideal energies lying between the ultimate reality and our present order of things, and also indicates the transition between those Ideas and the present world; a passage which is interesting, also, as showing with special distinctness the blending in Erigena of the two great labours which the Greek spirit performed after it had been driven from its home and was losing itself among the Gentiles-the theology of Plotinus, the theology of Nicæa. "The primordial causes, then, as I said before, are what the Greeks call Ideas; that is, the eternal species or forms and the unchangeable principles after which and in which the world visible and invisible is formed and governed. Hence by the Greek sages they came rightly to be called $\pi \rho \omega \tau$ ó $\tau v \pi \alpha$, that is, original types or pattern-forms, which the Father made in the Son, and which by the Holy Ghost are distributed into their effects and

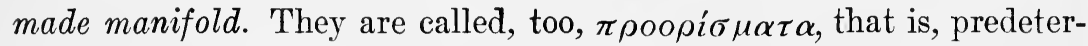
minations (or foreordinations); for in them whatever things by divine

soon, however, as they proceed into their infinitely manifold effects, they take on their vast and orderly plurality; not as if the cause of all things were not also order and arrangement, or as if arrangement in itself were not to be counted among the principles of things, when it is by participation in it that all orderly things receive their order; but because every order appe irs as one and simple, and is distinguished by no differences, in the highest All-cause and in the first participation in it, where all orders are unvarying from themselves, forming an indissoluble unity whence the manifold order of all things flows down." (III. 1.)

1 Not only, Erigena urges (e.g. in III. 16), are all things at once eternal and "become" ( facta) in the divine Word, but the divine Word itself makes everything and in everything becomes. It alone is the essence of the existent, the movement and separation of things that are distinct, the indissoluble connexion of the mingled and compounded, the foundation of the established; in a word, in all things it becomes all. 


\section{ERIGENA: THE DIVISION OF NATURE}

providence are coming to be or have come to be or shall come to be are all together and at once and unchangeably predestined. For nothing in the visible and invisible creature arises in natural wise except what in them before all times and places is predetermined and foreordained. In like manner, they are wont to be called by philosophers $\theta \varepsilon \tilde{\imath} \alpha \theta \varepsilon \lambda \dot{\eta} \mu \alpha \tau \alpha$, that is, divine volitions; for all things that God willed to make, He made in them primordially and causally; and all things that are to come into being, came into being in them before the ages. And, therefore, they are said to be the principles of all things, because all things that in the creature, whether visible or invisible, are perceived by sense or thought, subsist by participation in them. They themselves, however, are participations in the one Allcause, the highest and holy Trinity, and hence are said to exist in themselves, because between them and the one cause of all things no creature intervenes. And while they subsist unchangeably in it, they are the primordial causes of other causes which follow upon them to the uttermost limits of the whole created and infinitely manifolded Nature; " infinitely," I say, not in respect of the Creator, but of the creature-for the end of the multiplication of the creatures is known to the Creator alone, because He Himself and no other is that end. These primordial causes, then, which divine sages call the principles of all things, are Goodness in itself, Essence in itself, Life in itself, Wisdom in itself, Truth in itself, Thought in itself, and so with Reason, Power, Righteousness, Welfare, Magnitude, Omnipotence, Eternity, Peace, and all the powers and principles, which all together and at once the Father made in the Son, and according to which the order of all things from the highest to the lowest is framed (texitur), - that is, from the intellectual creature which, after God, is nearest to God, down to that last order of all things in which bodies are contained. For that which is good is so through participation in the Good in itself; that which subsists essentially and substantially subsists through participation in Essence in itself; that which lives possesses life through participation in Life in itself. So, too, that which is wise and intelligent and reasonable, is so only through participation in Wisdom in itself, Intelligence in itself, Reason in itself. And the same of the others. For there is in Nature no power, whether universal or 


\section{ERIGENA: THE DIVISION OF NATURE}

particular, which does not proceed, by an ineffable participation, from the primordial causes."

The position indicated in the italicised words of the foregoing passage, Erigena makes more explicit elsewhere. Father, Son, and Holy Ghost, he says, are three causes in one cause. The Father is the begetting cause of the only-begotten Son, who on His side " is the cause of all the primordial causes, which in Him are created by the Father. The same Father is the cause of the Holy Ghost, who proceeds from Him through the Son, and the Holy Ghost in turn is the cause of the dividing, manifolding, and distributing, of all the causes created by the Father in the Son, into their universal, special, and proper effects, according to Nature and according to Grace." again, in another connexion, "If, then, there is nothing to be perceived in the nature of created things except what is given them by the Creator, it follows that the creature, with regard alike to its essence and its accidents, is nothing other than a gift of the Creator; and the dispensation of the gifts theology ascribes to the Holy Ghost as His peculiar function. All, therefore, that the Father does in the Son, the Holy Ghost dispenses, and, as He will, divides to each thing its own. Seest thou not, then, how theology is able to attribute severally to the substances or persons of the divine Goodness, as it were, their special properties? The Father (so it affirms) does all; in the Word, universally, essentially, and simply, all the primordial causes of things have eternally their origin; the primordial causes originating in the Word, the Spirit distributes, like seeds with power of growth, into their effects-i.e., into the genera and species, the numbers and distinctions, whether of celestial and spiritual essences altogether without bodies, or of essences clad with purest spiritual bodies constituted of the simplicity of the universal elements, or of the sensible existences of this visible world-existences universal or particular, separate in space, movable in time, differing in quality and quantity." 3 And this view of the function of the Holy Ghost as one of the persons of the Trinity, can be proven, as Erigena remarks (a few sentences before the passage just quoted), from the testimony of the Apostle (Alii per Spiritum datur sermo sapientiae, alii . . . 1 Cor. xii. 8-11), or

1 II. 36 (italies nine).

2 II. 32.

3 II. 22. 


\section{ERIGENA: THE DIVISION OF NATURE}

from the Book of Genesis, where it says: Et Spiritus Dei fovebat aquas. For to what other purpose could the Spirit of God have cherished and made fruitful and nourished the waters (which upon Erigena's allegorical interpretation are the causae primordiales), than to distribute and arrange, according to the distinctions of classes and forms, of wholes and parts, and of all numbers, that reality (the causae primordiales) which in the Word was created in uniformity, unity, and simplicity?

The causae primordiales which are one, as created by the Father in the Word, are, then, made manifold and distributed into their effects by the Holy Ghost. For Erigena, a living and continuous divine energy is thus both the principle of unity of the Ideas, and the source of that expansive power and creative energy by which they proceed from themselves and give rise to the orders of particular being which make up the third Form of Nature. This transition from the Ideas to the things of the present world had been a diffieulty both for Plato and for Plotinus. Plato, as we have seen, worked his way steadily toward a solution of it. He came more and more to regard the hierarchy of the Ideas not so much as a universe complete in itself, abiding for ever in static perfection, and by that perfection rebuking this second universe in which we live; but rather as the order, the rational constitution, of the one universe to which all reality belongs. And this he could do, because he more and more came to regard the Ideas, not as mere forms of static perfection, but as creative energies sharing in the nature of that supreme principle which is at once the source of their reality and the principle of their organisation. While Plotinus, in tracing the descent from the voins through the world-soul to the world of particulars, can but bring up the same logical devices that he had already used in attempting to bridge a similar, but profounder, gulf-that between the One and the vois. But for Erigena, the Christian theology of the Greeks makes possible that which to the pagan theology of the Greeks was not possible. The selfmanifesting and self-communicating Father pours Himself forth through all the descending stages of existence, constituting the Ideas in the Son, and in the Holy Ghost distributing them into their effects.

It is not an easy task to reduce any aspect of Erigena's thought to 


\section{ERIGENA: THE DIVISION OF NATURE}

cold and systematic statement. And within the limits of the present discussion it is simply not possible to consider the details of the gigantic cosmogony which he works out in dealing with the third Form of Nature. From the causae primordiales-not out of nothing - proceed the four universal elements. ${ }^{1}$ These mediate between the purely spiritual primordial causes and particular bodies. ${ }^{2}$ So that matter is viewed as arising from the combination of incorporeal existences. For qualities and quantities which in themselves are incorporeal, by coming together bring into being formless matter, which by the addition of incorporeal forms and colours takes shape in diverse bodies (literally, "is moved into diverse bodies"-compare Aristotle's xív (1) the matter, (2) the immanent or individual form, (3) the essential or general (and therefore separable) form, he brings forward what is really Plato's and Aristotle's problem of the relation of form and matter, with the connected problem of the relation of essential and contingent. 4 Man, again, he views as created in the image of God, and therefore as containing within himself all created existences from the heavenly to the animal-so that "in man God has created the whole visible and invisible creature." "Although it remains to this day hidden, how far the first estate of man reaches, since his transgression by revolt from the hearenly light, still there is nothing naturally present in the celestial essences which does not subsist essentially in man." "The whole sensible world is created in him; no part of it can be found, whether corporeal or incorporeal, which in created man does not subsist, feel, live, and become incarnate."

With the details of this part of Erigena's system, however,-and with the great allegorical exposition by which he brings both this and other parts of his system out of the opening chapters of Genesis-it is impossible here to deal. But although we cannot go into the details, yet if we are to understand Erigena at all, we must consider the broad movement of thought, and the chief logical motives, in this part

1 III. 14.

2 III. 26. Compare the phrase in III. 27. “. . . the threefold creation of the world, namely, in its grounds (rationibus), its universal elements, its particular and compounded bodies."

3 III. 14.

4 III. 27.

5 IV. 7 seq. 


\section{ERIGENA: THE DIVISION OF NATURE}

of his account of the world. For what it contains is precisely that dualism which we have already seen in Plato and Aristotle, and which haunts theology to this day; the dualism that arises from the sense, on the one side, of the perfection of God as the source of the world; on the other side, of the imperfection of the world which has come from that God.

That dualism may be said to be absolutely inevitable for all affirmative theology which is not able to view the process of the world and of man's spiritual history, from the point of view of development or evolution. And this conception and point of view, it should be understood, is not forced upon theology from the outside. It is called for from within. For anything that can be called affirmative theology at all, must view God as a self-communieating being; as a being whose nature it is to impart his nature. And that means that God must give rise to spiritual beings of a nature kindred to His own, and must impart Himself to them. But such impartation on God's part means struggle on their part. For unless in some very real sense they earn their own life and achieve their own perfection-unless, in one word, they "have life in themselves"- - they cannot be regarded as beings to whom God imparts Himself. They would have simply a life and a perfection laid upon them from the outside; would have no life or perfection of their own. They would, in fact, in their unsuffering and untormented innocenee, be (morally, if not metaphysically) modes of the divine substance, rather than spirits made in the likeness of God-spirits in whom God reproduces Himself, and to whom, therefore, and only therefore, He can impart Himself. So that, as we have already seen, ${ }^{1}$ affirmative theology must view God in creation as making the actual, empirical beginning with something less than His own eternal perfection, and from that beginning leading created beings onward through a process of development, which from God's side may be described as an ever-increasing impartation of Himself, but from man's side as a desperate struggle upward through evil. But Plato and Aristotle-all the more remarkably in Aristotle's case because he does see evolution in nature-cannot admit such a view. Any result of the divine activity, any creation of God,

1 Supra, p. 82 seq. Cf. p. 242 seq. and p. 258. 


\section{ERIGENA: THE DIVISION OF NATURE}

they instinctively feel, must have eternally in it the absolute and final perfection of God; if a creation-theory can be admitted at all, it must view the perfect and timeless maker as making a timelessly perfect work. But the world actually present to us is an order of becoming, and is full of imperfection. Hence Plato is foreed to a dualism (the admission of a co-eternal impeding principle in creation), which Aristotle hardens and makes more decisive. And for Erigena in his affirmative theology, this situation is intensified and made most acute. For he sees this present world as intimately in connexion with God; in fact, as he emphatically puts it, what God creates in the second and third Form of Nature is Himself; in those Forms, God "becomes," God "is created." Hence, for Erigena, if one may so express it, God in the world and the evil in the world stand directly face to face, and the problem that troubled Plato and Aristotle is intensified to the utmost.

We must briefly consider the presence in Erigena of each of the two insights whose opposition thus constitutes the ultimate-and desperate-problem of theology and philosophy. It is understood, of course, that in doing so we are confining ourselves to Erigena's affirmative theology; for the negative theologian, when he has reached his goal, has delivered himself even from this problem; he has but to be still, having come to his rest in God.

First, Erigena never wavers from the height of his assertion of the unity, and eternity, and divinity, of Nature through all its Forms. This does not mean that he deifies the rocks and trees. It means that for him God is all in all; it means that he has penetrated beyond the appearance of the things of the earth to their reality, and has found that reality to be God. In all ereation God creates Himself ; in all becoming it is God that becomes. All the four Forms of Nature are the procession of God, from Himself, through Himself, to Himself. " . . . To God there is nothing future, for He includes (concludat) within Himself all times together with their eontent, and is the beginning, the middle, and the end, the extent and course and return of all things." "Thou compellest us now to eonfess," the Scholar presently replies, "that God is all-all that is said to be eternal, all that is said to have become. For if the divine will and 


\section{ERIGENA: THE DIVISION OF NATURE}

the divine vision are essential and eternal, and, for God, being, willing, and seeing, are not different things, but one thing, and that superessential; if, furthermore, all that makes up the object of his willing and seeing can reasonably be understood as nothing other than Himself, since a simple nature can admit in itself nothing which it itself is not: then beyond all dispute no other conclusion remains than to confess that the one God is all in all. . . . If the nature of the divine Goodness," the Scholar farther admits, "is distinct from that which God saw as something destined to become, and made,-saw thus, and made, in Himself-then the simplicity of the divine nature is rent apart, if an Other is understood in it which is not itself. But this is absolutely impossible. And if the divine nature is not distinct from that which it saw in itself as something to be made; if it is, rather, one and the same divine nature, whose simplicity is inviolable, and whose unity is indivisible; then with certainty it follows that God is everywhere all, and wholly in everything, at once the maker and that which is made, the seer and that which is seen, at once the time and place and essence and substance and accidents of all things; in short, is everything which truly is or is not; superessential in the essences, supersubstantial in the substances, high above every creature as Creator, and within every creature as created [in the creature God creates Himself], and underneath every creature as subsistent [or, as substratum], beginning to be from Himself, moving Himself through Himself, and moved to Himself, and resting in Himself, made infinitely manifold in Himself through genera and species, without any loss of the simplicity of His nature, and calling back into Himself the infinity of His manifoldness. For in Him all things are one." "Now I see," is the Master's answer, "that in place of thy doubts clear insight has come, and that thou wilt no longer hesitate to confess that all things are at once 'become' and eternal (et facta et eterna), and that everything which is seen truly to subsist in them is nothing other than the ineffable nature of the divine Goodness." . . . "The conclusion is, that in all things, it [the divine nature] alone truly and properly is; and nothing which is not that nature truly properly is. . . . So that we ought not to regard God and the creature as two existences distinct 


\section{ERIGENA: 'THE DIVISION OF NATURE}

from each other; rather they are one and the same. For the creature subsists in God, and God in wonderful and ineffable wise is created in the creature; revealing Himself; the invisible making Himself visible, the incomprehensible making Himself comprehensible, the hidden, open, the unknown, known; the God above form and appearance making Himself beautiful in form, gracious in appearance; the superessential making Himself essential, the supernatural, natural, the simple, complex; the God exalted above accidental qualities making Himself subject to such qualities, and becoming such a quality; the infinite making Himself finite, the uncircumscribed, circumscribed, the supertemporal, temporal, the superlocal, local; the Creator of all being created in all, and the Maker of all made in all; so that the eternal begins to be, and the immutable is changed into all (immobilis movetur in omnia) and in all things becomes all. And this I say, not with reference to the incarnation of the Word, and His becoming man, but with reference to the ineffable condescension of the Supreme Goodness, which is Unity and Trinity, into the things which are, in order that they may be, nay, in order that it may be itself in all things from the highest to the lowest, always eternal, always 'become,' eternal of itself, ' become' in itself; while eternal, not ceasing to be become; while become, not ceasing to be eternal; and making itself of itself. For it needs not some other matter, which is not itself, in order therein to make itself; else would it seem powerless, and imperfect in itself, if from some other where it received aid for its appearance and perfection. From Himself, then, God received the occasions to His theophanies-which is to say, divine appearances-for 'of Him, and through Him, in Him, and to Him, are all things.' And therefore the matter itself, of which the world is said to have been made, is from Him and in Him; and He is in it so far as it is regarded as having existence."

So that all things are divine and are a totum simul in God. That of which God made the world He took no other where than from Himself, and "neither sought spaces outside of Himself, in which to create, nor paid regard to times, in order in their intervals to complete His work, but made all things in Himself; since $\mathrm{He}$ is the space of all 


\section{ERIGENA: THE DIVISION OF NATURE}

things, and the time of times, and the age of ages, accomplishing all things together and making all things in the twinkling of an eye. For both those things which in the course of the ages have come to birth, and those that even now are coming to birth, and those whose birth is still to come, are all together and at once made in Him, in whom past and present and future are all together, and all at once, and all one."1 "God saw, then, that it was good, that is to say, God saw Himself in all things as the good. For God saw nothing but Himself, because outside of Him there is nothing, and all that is in Him is Himself, and his vision of Himself is simple and has its form from none other than Himself."'2

But over against this vision of the theologian to whom God is all and in all, and all cognisable things theophanies, stands the life of the present world. And as Erigena looks upon it, the problem is forced upon him which has been forced upon all the greater theologians from Plato downward: How-and why-has evil come to have a place in a world whose source is altogether good? Erigena seeswhat any one who deserves the name of theologian must see-that the world is one as coming from one source; and that, therefore, in ultimate analysis, all the elements or factors of the world have their ground in one character and subserve one purpose. But, then, what account can one give of the place of evil in such a world? And if you can give no account-if you cannot see even the beginning or promise of an explanation-what right have you to retain your fundamental conception of the unity of all existence?-if you thus are really a Manichæan, what right, for instance, have you to call yourself a Theist?

We must distinguish, of course, between an empirical account of the origin of evil and a metaphysical account. The empirical account simply describes as a matter of fact how evil comes to be; the metaphysical seeks for the ground of evil, where all things must somehow have their ground-in ultimate eternity. An empirical account Erigena easily gives: evil arises from "perverse motions of the free will."3 In modern language, evil is the correlate of man's freedom. And when it is recognised that freedom on the part of man

1 III. 2i.

2 III. 28. 


\section{ERIGENA: THE DIVISION OF NATURE}

is necessary to any genuine self-communication on the part of God, the way is prepared for the metaphysical account which has already been referred to, ${ }^{1}$ and which, grave as are its difficulties, is at least free from self-contradiction-one part of it does not deny the other part.

But Erigena does not advance to this point of view; though there are hints of it in him $^{2}$ - as, indeed, there are in him hints of nearly everything in philosophy. On the contrary, he breaks at last that to which he so passionately held, the belief in the inviolable unity of all existence. He falls into a dualism resembling, not in expression, indeed, but in logical motive, that of Plato and Aristotle. Evil becomes to him what the "Necessity" of the Timaeus is to Plato, or contingency to Aristotle-virtually a co-eternal principle which interferes with the perfection of the ereated world. The very intensity of his idea of unity coupled with his lack of clearly-possessed organic categories, drives him into the following position.-(1) Evil, alike in its origin and in its being, lies outside of "Nature." "God, then, does not know evil. For if He knew evil, evil would necessarily be in the nature of things. For the divine knowledge is the cause of all things which are. . . . The cause of the essence of these things is the divine knowledge, and, therefore, if God knew evil, then evil would be perceived substantially in something; evil would participate in the good, and thus from strength and goodness defect and evil would proceed. But that this is impossible, true wisdom teaches."3 (2) How anything which thus has no place in Nature, which, indeed, contradicts

1 Supra, p. 242 seq.; p. 258 ; p. 303. Cf. p. 82 seq.

2 One of the :e-which may be said to present the theory in question in its static form (the form, Stoic and Leibnizian, which views eril as contributing to goor, not as the negative factor involved in development, but rather as the imperfection which presents itself when you 'ook at the single finite individual instead of at the whole)-is specially striking: "How," an objector is imagined to say, "can God, exalted high over a'l, invisible, incorporeal, incorruptible, descend from Himself; and create Himself in all things, in order to be all in all; and, in His forthgoing, advance to the last visible hatefulnesses and corruptions, to the meanest forms and species, of this world, in order to be in these, if He is all in all?" "He," ru"s the answer, "who so speaks, knows not that in the total universe of the creature there can be nothing hateful, that it no evil can mar, that it by no error can be deceived or led astray. For what concerns only a part, Gnd does not permit to become in the whole, since, upon a view of the whole, neither is [what had seemed] hatefulness hateful, nor does any evil injure, nor any error mislead." (III. 20.)

3 I. 28. 


\section{ERIGENA: THE DIVISION OF NATURE}

and opposes Nature, could come into existence at all-for, of course, there are no sources outside of Nature-is a "mystery." Yet even here Erigena has a glimpse of a solution; a glimpse to which only a doctrine of development as a divine method could do justice. " Everything which in 'natural' wise is created in man, remains of necessity eternally inviolate and uncorrupted. . . . The rational and intellectual nature, although it was not willingly deceived, yet could be beguiled, especially since it had not yet received the perfection of the form which-destined as that nature was to a course of transformation ending in theosis, that is to say, deification-it was to have received through the merit of obedience (perfectionem . . . quam merito obedientiae esset acceptura in theosin, deificationem dico, transformanda)." (3) Evil, once it had thus by perverse motions of the will arisen, explains the dividedness and imperfection of the third Form of Nature. A single passage of many will make Erigena's view clear. "For, as reason teaches, this would not have fallen apart into its manifold sensible species, and into the motley diversity of its parts, if God had not foreseen the fall and ruin of the first man, who forsook the unity of his nature; to the end that man-at least after his fall from the spiritual realm to the corporeal, from the eternal to the temporal, from the incorruptible to the perishable, from the highest to the lowest, from the spiritual man to an animal, from a simple nature to the distinction of the sexes, from angelic dignity and multiplication to the shame of the birth of our corruptible bodies-being admonished by a penalty so dire, might come to recognise his pitiable ruin, and seek to return to the condition of his pristine dignity by repentance and the putting off of his pride and by the fulfilment of the divine laws which he had transgressed. For it cannot be believed that the most divine charity of the Creator has thrust sinful man down into this world as if through some movement of wrath or desire of vengeance; since true reason shows us that the divine Goodness is free from these non-essential qualities (his accidentibus). Rather it can have happened only in consequence of an ineffable principle and of mercy incomprehensible; to the end that man-though by the choice of his free will he had refused to maintain himself in the

IIV.5. 


\section{ERIGENA: THE DIVISION OF NATURE}

dignity of his nature-taught by punishment, should seek the grace of his Creator; and, obeying by the help of that grace the divine commands which earlier he had neglected out of pride, careful and cautious and mindful of his earlier negligence and of his proud humiliating fall, should turn back toward his ancient state, from which - preserved by grace and by the free choice of his own will-he should not fall again, nor wish to fall, nor be able to fall."

Such, then, is Erigena's account of the forthgoing of the divina bonitas, and of the Forms of Nature which thus arise: the second Form, the world of Ideas, a system of perfect types and perfect energies; the third Form, our present world, the result partly of the farther procession of the divine goodness, partly of man's sin. With this, we have to turn to the last of the: Forms of Nature, that in which all things return to their source in God. In the light of what we have just seen, this will be not only the natural return of all things to their source, but also their redemption from evil. And if Erigena is to be understood, special attention must be given to this part of his thought. Just as we do not understand Dante at all if we read only the Inferno-because "it is interesting, while no person can live in the white light of the Paradiso"- so we shall not understand Erigena at all, nor indeed any mediæval theologian, unless we walk with him while he unfolds his highest hope and ultimate vision.

But before turning to this we must stop for a moment upon an aspect of Erigena's thought, which is very important, but which the course of the discussion so far has given us no opportunity to bring forward. This is what we may call his Idealism. The whole of that reality about which it is possible for science or philosophy to make affirmations is, he sees, of the nature of thought. And to this Idealism he comes from both sides: from the side of the material order; from the side of God. In the first Book, in dealing with the inapplicability of the ten categories to God, he works out a sort of "immaterialism"; he reduces the corporeal to the incorporeal. Matter is a combination of incorporeal qualities and quantities. And the form which holds it together is incorporeal. And this immaterialism passes over into 
express Idealism when it is said that space is arrangement or order, and therefore subsists only in the mind; space is a definition, and its determinations must be the activity of a rational and thinking nature; space is something thought in the soul, and is therefore incorporeal. Hence, indeed, it is, as Gregory of Nyssa says, that from a God whose nature is that of thought or spirit, a "material" world can come. While from the side of God, he equally maintains that all created existence is of the nature of thought. "God," he says, in dealing with the problem of evil, "does not know that which is, because it subsists; but it subsists because God knows it. The cause of the essence of that which is, is the divine knowledge." "The knowledge of the saints in the Wisdom of the Father," he says again, "is the creation of them. For the perception in God of all things is the essence of all things."3 In a word, God's knowledge of an existence is that existence. Or, to put the same conception into more modern terms, the objective reality of anything means its presence in the divine mind. It will, of course, be understood that this does not necessarily deny selfhood-real individuality or the germ of it-to created beings; and, therefore, is not necessarily Pantheism.

Furthermore, Erigena in his affirmative theology is not only an Idealist in the sense of asserting that all reality which science or philosophy can investigate is of the nature of thought or spirit. $\mathrm{He}$ really possesses also the true point of departure of Idealism: he sees that spirit as it is in man is an active principle of synthesis. $\mathrm{He}$ delights to pourtray the human soul as not imprisoned in space, nor compelled to "reach out into space," but as having-to use modern language - a synthetic activity which is above the dividedness of space and time, receiving at one and the same time, and into one and the same experience, the most manifold kinds of sensation, retaining these in memory, arranging and judging them. ${ }^{4}$ Hence, when he goes on with equal intensity to describe the soul as simplex, free from all union or composition of distinct parts, he can only be understood as having a conception of the soul which he is not able clearly to express-the conception of it as a diversity-in-unity, a principle and activity of synthesis. The very reason which he gives in insisting upon its
1 I. 27-61.
2 II. 28.
3 II. 20.
4 III. 36. 
simplicity shows this. It is a simplex, free from all composition of distinct parts, he says, because "in itself it is in its wholeness everywhere throughout the whole. It is the whole life, the whole understanding, the whole reason, the whole of sense, the whole memory, and, as this whole, it animates, nourishes, maintains and increases the body. As the whole soul, it, in all the senses, perceives the forms of sensible things. As the whole soul, it deals with, distinguishes, combines, separates-going far beyond every bodily sense-the nature and reason of the sensible things themselves. As the whole soul-beyond and above every creature, and above itself as a being included in the world of creatures-it circles in intelligible and eternal motion about its Creator, becoming purified of all vices and imaginations." And, as Erigena goes on, in this very simplicity, it receives distinctions and distinct names according to its activities. In its motion about the divine essence it is Mind and Soul and Understanding. In dealing with the natures and causes of created things it is Reason. In receiving sensuous images, it is Sense. As animating the body, it is the Vital Principle. But in all these activities it is everywhere the whole soul. ${ }^{1}$ 'The same insight appears in Erigena's view of the soul as a microcosm, which we shall have to consider in another connexion.

Thus, then, Idealism is present in the De Divisione Naturae; Erigena has both its true point of departure and its specific insights. But neither the age that he lived in, nor the history that lay behind him, nor his equipment of categories, permitted the Idealism in him to come fully to its right. With his inheritance of the Christian theology of the Greeks, he stood between two worlds, the one of which had spoken in Plotinus and Proclus, the other of which was to speak in Hegel. To both of those worlds his heart was given; and the result was that Idealism was present in him not as expressing his highest insight and last conviction, but simply as one stage in that desperate journey of the intellect which is set for any man who is a Mystic, and yet cannot plainly and flatly deny the reality of the present world.

We have to return, then, to the subject already before us-the 1 IV. 5. Cf. 11. 
fourth Form of Nature. It would seem at first sight as if Erigena's work of explaining the world were already done, when he had given his account of original reality and of the derivation of our present world from it. But we have already seen that his instinct for unity drives him farther. The world has come from one source, but it is nevertheless not one. It is beset by dividedness; and by dividedness of a particularly unforgivable kind-sensuous manifoldness, diversity in space and time. And worse still, it is torn apart by the dualism of good and evil. Futhermore, to the discontent of the philosophic and moral mind there is added the discontent of the specifically religious mind: God must be all in all, and all things that have proceeded from Him must return to Him.

So, then, we come to a fourth Form of Nature, which neither is created nor creates, but in which all things rest eternally in their home and unity in God. In attempting to deal with this, we must first notice the general principle which guides Erigena in this part of his work, and must then indicate very briefly the main steps in the return of all things from their multiplicity and dividedness in the third Form to their rest in the fourth.

To Erigena it is a general principle of Nature that things return to their beginnings. The source from which they proceed is also their goal. This is seen even in corporeal things; and as so seen, it mystically intimates to us (for "there is, in my opinion, nothing among visible and corporeal things which is not a sign of something incorporeal and intelligible") "the return of our nature to the source whence it originated, and in which and through which it moves, and to which it always strives to return. Universally in all men, whether they be perfect or imperfect, pure or defiled, made new by knowledge of the truth in Christ or cleaving to the old man in the darkness of ignorance, lives one and the same natural desire for being, and wellbeing, and abiding being, or, as St. Augustine briefly expresses it, the desire to live happily and avoid misery. ${ }^{1}$ But this impulse after living happily and having substantial existence is from Him who is eternal and is good and is immanent in all things. And if every natural motion, of necessity does not cease nor rest, until it has reached the 
goal toward which it struggles, what can avail to hinder or restrain or bring to a stand the necessary movement of human nature, so that it shall not be able to reach that for which it naturally strives?" And even, "if godlike Nature has somehow through unlikeness become remote from its source, it strives always to return thither, in order to attain again to the likeness which it had marred."1

This principle itself is made possible for Erigena by the fact that it is really one and the same nature which is present in the first, second, and third Forms. In the first Form, that one Nature is viewed as the beginning and cause of all; since it has nothing preceding it which could stand to it as cause or beginning, it is called "Nature creating and not created." Then, in the second Form, where it is "both created and creating," it is the same Nature. For the primordial causes are that Nature "creating itself" and so going forth in theophanies. And then in those theophanies it still farther proceeds from, or unfolds, itself, coming forth from the most concealed limits of its nature, in which it is unknown even to itself, that is to say, recognises itself in no being because it is unconditioned and supernatural and superessential and above everything that can be thought or not thought. When it thus descends into the principles or original grounds of things-into the causae primordiales-and, as it were, creates itself, it begins to be in particular and definite forms. Then, further, it has to be considered in the last effects of the primordial causes, wherein it is rightly viewed simply as a nature which " is created, but does not create." In these effects it comes to the end of its forthgoing and manifestation-its self-externalisation, as a modern terminology would have it. Just on this account, every corporeal and visible creature given to our senses " is wont in the Scriptures not unjustly to be called the last trace of the divine nature (extremum divinae naturae vestigium)." This trace "it is vouchsafed to every contemplative mind to gain sight of, when, like another Moses, it ascends the height of the mount of vision; although, indeed, it can scarcely be distinguished clearly (ad purum) even by the spirits of the wise; for the smoke of earthly imaginations, and the tumult of changeable things, and the gleaming illusion of the things that

1 V. 3. 


\section{ERIGENA: THE DIVISION OF NATURE}

suddenly are born and pass suddenly from us, stand as hindrances in the way. Only very few-those that from earthly thoughts wholly have set themselves free, and by virtue and knowledge are purified-attain unto it, to know God in these visible creatures:"1 as, for instance, the patriarch Abraham did, when, guided by the law of nature, he recognised the Creator from the revolution of the stars; and other holy Fathers before the written law, and in the law-as Moses in the bush and upon the mountainpeak. But, in addition to these three Forms, there is still another way in which the one Nature must be viewed: "When we recognise this same divine nature as the goal of all, beyond which there is nothing, and in which all things eternally subsist and in their universality are God, then we rightly call it neither created nor creating. Not created, because it is created of no one; not creative, because it ceases to create when all things are transformed back into their original grounds (wherein they will remain eternally and do remain) and cease to be known by the name creature. For God will be all in all, and every creature, transformed into God, will enter into shadow, as the stars at the rising of the sun. Seest thou not, then, upon what ground one and the same nature, namely, the divine, can be called from the point of view of the beginning not created, but creating, but from the point of view of the end or goal neither created nor creating?"2 In fact, it might almost be said that Erigena's distinction of the four Forms of Nature is a device of exposition, a device for the convenient setting forth of his view of the one system of the one universe. The first and fourth Forms express the unity, the

1 Compare the following from II. 18: "The first causes, then, both make their way (proveniunt) into the things of which they are the causes, and do not forsake their source or beginning (principium), i.e., the Wisdom of the Father, in which they have come to be, and-remaining, so to speak, in themselves invisible, hidden for erer in the darkness of their splendour, but in their effects brought forward as it were to the light of knowledge -appear without ceasing." Or the following from the Scholar in V. 24: "Far be it from the hearts of the faithful to think that everything which has come to be in the Word of God, is not life-life wise and eternal, without temporal beginning, without temporal end. For both the realm of bodies, and the whole sensible creation, are, in the Word of God, life wise and eternal, so that, in a way ineffable and incomprehensible but yet credible, erery creature lives in the Word of God, and in that Word is life; and the divine Word-since outside of it is nothing-moving as it were toward externality, has brought forth out of itself all created creatures."

2 III. 23. 


\section{ERIGENA: THE DIVISION OF NATURE}

second and third the diversity or manifold of types and of particulars. And all four are alike God or in God; for "God is the beginning, the middle, and the end [i.e., source, process, and goal] of the whole created universe; not as if it were for Him three distinct things to be beginning, middle, and goal, since these three are in Him one; but because the movement of theological contemplation is threefold." And what drives Erigena to adopt so vast and complex a scheme of exposition is the fact that he has to work into one system both the negative and the affirmative theology.

As Erigena passes on to consider the regressus which leads to the fourth Form of Nature, one expects him-in the light of what he had said about the first Form of Nature-to return finally and completely to his negative theology, to his Mysticism. And that not only as moralist or preacher, advising men to lay aside all entanglement with the particular and the individual, and to find their true being by losing themselves in God; but as a metaphysician, declaring that, as matter of fact, the final outcome of the whole process of the created universe will be its passage to its rest in the "still abysm" of the ineffable God, in which all things will become God, and so become truly themselves, by ceasing to be themselves as particular distinct existences. In that way the Erigena of the fourth Form of Nature would decisively complete what the Erigena of the first Form of Nature began. But as we go on to consider the details of Erigena's last and highest view of Nature, his view of the ultimate outcome of the world's process, what we find is that the Idealist has gained upon the Mystic. In the ultimate outcome of things, individuality, instead of being negated, is made complete. Or rather individuality is in part negated, in part affirmed. But the negation is insisted upon in the interest of the affirmation; it is involved, Erigena thinks, in the true advance of human individuals to their perfection; is involved in their rise to their Idea, in their return to their true home in the Word.

The regressus is described as having two forms or stages. There is, first, a universal regressus which is the work both of nature and of grace, and, secondly, a special regressus which is granted only to pure hearts and is the work of grace alone. ${ }^{2}$ The former is the return of 


\section{ERIGENA: THE DIVISION OF NATURE}

all things to their "beginnings in Nature"; i.e., it is the exaltation of all things to their Ideas, their primordial causes, and is thus a general return of the third Form of Nature to the second. This, as we have already seen in dealing with the general principle which here guides Erigena's thinking, he regards as the regular course of Nature. But, in addition to that, there is a special pressure upon him to assert such a universal return. The third Form of Nature cannot quite vindicate itself. It must be condemned metaphysically, as a realm of sense, subject to dividedness in time and place; and morally, because of the presence of evil. It is as if Nature has in the third Form sunk below itself, so that without possibility of exception the particular beings into which the inviolable divine Nature has created itself, strive by their own natural motion back to their Ideas. There are even expressions in Erigena which seem to show him as holding this opinion from the point of view of the particular existences themselves. $\mathrm{He}$ seems to feel that the elementary justice of the universe-that "ultimate decency of things" in which Robert Louis Stevenson declared he would still believe though he woke up in hell-requires that the return to the primordial causes should be shared in by all existences whatever. It rescues, so to speak, the individual existences from the evils which their particular and divided life had forced upon them, and restores them to their own true and normal-in the Platonic sense, ideal-being. They had been something less than themselves; this return simply makes them themselves; and therefore it both is, and ought to be, undergone by all existences.

This universal return, then, means that each particular existence is purified of the dividedness and imperfection of the third Form, and returns to the perfection and completeness of its eternal type, and thus rises to the second Form of Nature, all whose perfect existences-the primordial causes-are one in the Word and therefore one in God. Each human being, for instance, will return to the Idea of man; that is, he will rise above the division of sex, and above the limitations of space and time, and enter into the normal or intended completeness of human nature. This, of course, involves a great abstraction; the abstraction involved (on the common interpretation of Plato) in 


\section{ERIGENA: THE DIVISION OF NATURE}

passing from an individual being of this present world to its Idea. ${ }^{1}$ But this-even upon the severest interpretation-is not yet the complete abstraction of Mysticism. There may be a loss (Erigena would not call it loss) of individual peculiarities in rising to the form of the eternal type. But there is no such complete sinking of individuality as in that mystical outcome in which all things lose themselves in the "still wilderness where never was seen difference, neither Father, nor Son, nor Holy Ghost," where "there are neither angels nor saints nor choirs nor heavens," where "there is naught but God," so that "no soul can come to God 'unless he becomes God as God was before the soul's creation."

The universal return involves, in Erigena's view, two stages. First, there is in general the transformation of the whole world of sense; i.e., " the transmutation of all bodies, whether those subject to the bodily senses, or those that by reason of their exceeding subtlety escape the senses;" for " in all that, which is substantially instituted by the cause of all things, nothing will be brought to nothingness." Secondly, there is the general return of the whole of human nature, saved in Christ, to the pristine state of its creation, a return, as it were, to Paradise, to the dignity of the divine image, through the merit of Him whose blood was poured out for the common salvation of the whole of humanity. This holds impartially of all men; so that no man will be robbed of those natural goods, which make up human nature according to its Idea-which make up what was wont to be called " Adamic perfection."

But in dealing with such a universal return of the world and of man, there at once arises a great difficulty. We have already seen how the fact of evil drove Erigena into a sort of dualism in describing the passage downward from the second Form to the Third. And now that he is tracing the reverse movement, the movement of all things upward from the third to the second Form, a kindred difficulty stands in the way: there is the fact of evil; and there is the church's doctrine of endless punishment in hell.

1 There are, however, nassages in Erigena which, if carried to their logical conclusion, would make the abstraction greater even than this. See the two passages quoted in the note to p. 297 supra.

2 See the concluding summary at the end of V. 39, where the first two forms belong to the universal return; while the third is that special return which is deificatio. 


\section{ERIGENA: THE DIVISION OF NATURE}

Erigena's discussion here is really a farther application of principles which we have already had to notice. As we have seen, he regards Nature as one and divine through all its Forms: the first Form is God as source; the second, God creating Himself as the eternal types or Ideas; the third, God creating Himself as particular existences. Hence, all that he could say of evil was, that it arises from "perverse motions of the free will," but has no essential place in "Nature." What he now does is to apply this principle in a form which gives us the central principle of the theologian whom he admired so much; Origen's great principle of the permanence of all spiritual substance; though Erigena's use of it is subtle and brilliant where Origen's was solid and profound. What God creates, urges Erigena, cannot be anything else than the divine nature itself. And that nature can neither perish, nor be subject to punishment.

As we go on to notice at slightly greater length the details of the discussion, it is due to Erigena to set special emphasis upon one thing: this man of the ninth century, writing in an age when torture and pain, when the temper and the habit of vengeance, were familiar parts of life, shows in his discussion a touch of the charity of Christ, and a vision of God as exalted above mere vengeance, which in similar discussions in more enlightened ages have frequently been wanting. Erigena may have fallen into grave intellectual errors; with his intellectual inheritance it was inevitable that he should. But into two things, which may be dead in the twentieth century, but were not dead in the nineteenth, he did not fall: into that darkening of the divine righteousness, which transforms it from a righteousness of God into a "radical wrong of man"; and into that Manichæism which, in its very zeal to free God from all connexion with evil, really removes Him from His place as God, by viewing a power hostile to Him as a co-eternal principle of the universe, and as at last partly victorious over Him and over His purpose.

Beginning with the prophetic word, lest he put forth his hand, and take also of the tree of life, and eat, and live for ever,-in which word "the return of human nature to the blessedness lost through sin is most clearly promised"-Erigena goes on to remind his disciple of the conclusion previously reached, "that the Paradise from which 


\section{ERIGENA: THE DIVISION OF NATURE}

man was banished is nothing other than human nature itself as created in the image of God; and that it fell from this its height because it disdained the command of God." From this it follows that "the banishment of man from Paradise is nothing other than the loss of the natural blessedness for whose possession he was created. For man has not-lost his nature, which, being created in the image and likeness of God, is necessarily incorruptible; he lost only the blessedness which he would have attained, if he had not scorned to be obedient to God."' As the outward form of man may be disfigured by leprosy and yet remain the form of man, so human nature by its high-minded disobedience is hatefully disfigured, but does not cease to be human nature. And "when it is freed from this leprosy through the healing grace of God, it will be called again to its pristine beauty. Nay, one may even say, that the nature created in the image of God never has lost, never can lose, the living strength (vigorem) of its beauty, and the integrity of its essence. For the divine form remains unalterable for ever; and yet, as a punishment for sin, it has become capable of things corruptible"-capable of the change and particularity of the present world. ${ }^{2}$ Hence, as was indicated in a passage already quoted, ${ }^{3}$ we must believe that in the banishment of man from Eden, it was God's mercy, rather than His punitive righteousness, that was active. For it was God's purpose to regenerate and illumine man, and make him worthy to come to the tree of life, from which he had been driven, and to eat of it so that he might not perish, but might live eternally. Therefore it was that the cherubim were set in their station at the east of Eden; for the cherubim signify the Word of God, in which the treasures of knowledge and of wisdom are hidden, and which without interruption stands ready for man's gaze, so that human nature may be warned and illuminated and purified and led back at last to unflawed completeness. And likewise the flaming sword signifies the Word of God, which consumes our sins, and purifies our natures, and at the same time distinguishes between our nature and that which cleaves to it through the guilt of sin, and hatefully disfigures it, and makes it unlike the Creator. So that the flaming sword applies itself ineffabili sua clementia et misericordia to the

$$
1 \text { V. 1, } 2 .
$$$$
2 \text { V. } 6 .
$$$$
3 \text { Supra, pp. 309, } 310 \text {. }
$$ 


\section{ERIGENA: THE DIVISION OF NATURE}

healing of human nature. Always before the eyes of our soul stand the cherubim with the flaming sword to keep the way of the tree of life-to keep the way of the tree of life, not in the sense of forbidding our access, but in the sense of preventing us from ever forgetting that tree, so that continually we may have before the eyes of our spirit both the tree itself and the way of approach to it. ${ }^{1}$

So Erigena agrees with the opinion of "the great theologian Gregory," that "evil is not so strong that it can overcome the power of good." It cannot, like good, proceed to infinity; it is sternly restricted within necessary limits. It " cannot be perpetual, but by the necessity of things is to reach an appointed bound, and is sometime to cease." Just because the divine goodness is eternal and infinite, its opposite cannot be eternal or infinite. ${ }^{2}$

But does not this bring us, asks the Scholar, into contradiction with the accepted teaching that human nature is partly (in the elect) to be redecmed, partly (in the godless) to be damned to eternal fire ?3 Erigena replies by asserting in accordance with the principle already noted, that God punishes no nature which He has created, whether in human or devilish substance; in all creatures, God punishes only that which He has not made, namely, the irrational motions of the perverse will. Of the evil spirits, that alone which was created in them by God Most High can remain, and is in no wise subject to punishment; but that which is not from God, namely, their evil, will perish, in order that an evil permanent and co-eternal with the good, may not have place in any creature whether human or angelic. The same is true of death and misery, lest something hostile to life and blessedness, and co-eternal with these, should arise. ${ }^{4}$ And when it is said that the last enemy will be destroyed - the last enemy with whose destruction all sorrow and death, all enmitie and separations, will cease-this does not mean that his substance, created of God, is to perish, but that his hostile purpose and will, which proceed not from God, but from himself, are to perish. He is to be destroyed, not in the sense that he will no longer exist, but, as "the great Origen" perceived, in the sense that he will no longer be the Enemy and Death. ${ }^{5}$

It is putting the same general position into another, and a very
1 V. 2.
2 V. 26.
3 V. 27.
4 V. 28.
5 V. 27. 
telling, form, when Erigena urges that God is the only principle of eternal existence, so that anything which is eternal can have its being only in God and through God; and, therefore, evil cannot be eternal - cannot be an absolute and final principle of the universe. ${ }^{1}$

His discussion of "that eternal fire, the torture, the burning sulphurous pool," is what might be expected from the principles just noted. In gentleness and spirituality, in freedom from heathen imaginations and from the spirit of savagery, this theologian of the ninth century stands far above many teachers of a later day. The fire is that of undying memory, of late repentance, of earthly imaginations and a love for earthly things which can no longer find any corresponding object. ${ }^{2}$ But if it be asked how such memories and imaginations can retain a place in "Nature" - so that that which lies outside of Nature and is contrary to it, is endured by the power of Nature, and within Nature is punished, Nature itself remaining always and altogether inviolate in itself-Erigena can only answer by the theologian's recourse to mystery; we must give place to the incomprehensible power of God, and honour it with silence, for at its entrance reason and insight are rebuked. ${ }^{3}$

When this sad problem has been discussed, Erigena is able to return to the real object and delight of his thought- to tracing the course of "Nature," the course of the normal and inviolate order of the world. The way in which he works out the universal regressus with which we are now concerned, may be briefly indicated as follows:

The process itself is one of synthesis or unifying. The nature of this unifying Erigena indicates thus: " . . . with regard to the unifying, this must of necessity always be heeded, that what is seen to be lower is taken up (moveatur) into that which is higher, that is to say, better; but a better never passes over into a meaner,

1 V. 30.

2 Of the Last Judgment, too, Erigena forbids sensuous images. The book, for instance, is that power of memory of which Augustine speaks in the words: "There is a divine power of the understanding, through which it comes to pass that for every man his works, whether they are good or evil, are in their totality called back into his memory, and with marvellous quickness are looked upon by the eyes of his soul, so that the knowledge accuses or excuses the conscience, and thus each soul of man is judged." (Quoted in De Div. Nat. V.38.)

3 v. $32,33$. 


\section{ERIGENA: THE DIVISION OF NATURE}

i.e., turns back in the renewal of the natures; else what would come to pass would be not unification, but division." In the universal regressus this unification takes place in the two stages already referred to: the unification of all natures in man; and the return of man to his natural place in the divine Word.

First, all the things of this world are created in man; so that in man's return to the second Form of Nature, they return also; or, as Erigena sometimes puts it, the sensible things of the present world, being included in human nature, participate in the resurrection. ${ }^{2}$ This view of man's position in the universe is found in many forms in Erigena. At times, following Maximus the Confessor, he regards man as a harmony of opposites, as the mediation and synthesis of all creatures, in whom the extremest antitheses of Nature are brought to unity, and through whom therefore they can advance to their final unity in God. ${ }^{3}$ Again, man is to Erigena the microcosm that corresponds to the macrocosm. This insight which is essential to any adequate theory of knowledge and usually enters philosophy in that connexion, is to Erigena the basis of man's return to God, and of the return of the world to God in and through man. He in one place makes a fourfold division of all created life-angelic intellect, reason as in man, sensible life as in animals, vitality without thought or sense as in plants-and shows how all these, not in mere external combination, but in true synthesis, are in man; so that, in the homely expression which Erigena loves to use, man is creaturarum omnium officina-the workshop of all the creatures-and in him the whole of Nature is contained." And, Erigena thinks, this must be so; unless it were, unless God "created every creature in man," man would not be truly "created in the image and likeness of God."

Then, secondly, human nature, which thus gathers up into itself all the world, is itself taken up into the Word. "He came forth from the Father, and came into the world, taking upon Himself the nature of man in which the whole world consists (in qua totus mundus subsistit); for there is nothing in the world which is not included in
1 II. 8.
2 V. 23.
3 II. 3-9.
4 III. 37 ; IV. 5.

5 IV. 7.-Erigena goes on to say, with a naiveté very unusual to him, that he absolutely does not know why, in preference to all the other visible and invisible creatures, God should choose precisely man, as the creature to be made in His own image. 
human nature. And again He left the world and went to the Father; that is, by union with His Deity, which is equal to the Father, He exalted the human nature, which $\mathrm{He}$ had received, high above all things visible and invisible, above all heavenly powers, above everything that can be said and comprehended. For, while He saved, wholly in Himself and wholly in the whole race of men, the whole human nature which wholly he had taken upon Himself, establishing some again in the previous condition of Nature [the universal regressus], but exalting others by pre-eminence above Nature and deifying them [the special return of pure hearts]; yet in no other but Himself is humanity made one with Deity in unity of substance, so as, transformed into Deity itself, to transcend all things."1 In another place, after dealing with an apparent deviation in Augustine, both from his own opinion as expressed in other writings, and from the teachings of his predecessors among the Fathers, "Ambrosius and the theologian Gregory," he goes on: "I, however, who detract from no one and strive with no one, unhesitatingly understand our Lord's own words: $I$ and the Father are one, as spoken not of His divinity alone, but of His whole substance, of God and man together."2

Through Christ, furthermore, it is that man is still able to perform this great function, even though he is fallen. For when fallen human nature, in the darkness of its perverted will, forgot both its Creator and its own original being; when it lay in wretched death, in the abysmal dark of ignorance, in farthest alienation from its own true nature and from its Creator, in shameful likeness to irrational and mortal creatures; then "no one was able to redeem human nature from this condition, to call it back, to renew it, and to establish it again in that earlier state from which it had fallen; but the divine Wisdom, which created it, and received it into unity with its own substance in order to maintain it in that state, has freed it from all misery. Let it not disturb thee, therefore, when it is said that human nature is everywhere whole in itself, both the [divine] image whole in the animal, and the animal whole in the [divine] image. Everything which its Creator created primordially in it remains whole and inviolate, but lies as yet concealed, awaiting the manifestation of the 
sons of God."1 The same view of Christ's general redemptive work as the restoration of universal human nature to its beginning-i.e., to its Idea, its primordial form as manifest in Eden-is seen when Erigena points out that the Redeemer of the world was free from that ignorance in which we are sunken at our birth, " not only because he was the Wisdom of the Father, for which there is no hidden thing, but because He took upon Him unstained humanity, in order to purify the stained; not as if He took upon Himself some other humanity than that which $\mathrm{He}$ restored, but because he alone remained without stain in it, and was preserved for the healing of the wound of corrupted nature in its most secret grounds. For the whole [of Nature ] came to ruin in all,- - save in the case of Him in whom alone it remained incorruptible. Therefore, He Himself is become the greatest example of grace, not because some indulgence was made to human nature on $\mathrm{His}$ account, but because $\mathrm{He}$ alone among all, without previous merit, was bound in unity of substance with the Word of God, so that in Him all the elect, drawing from the fulness of His grace, become Sons of God and partakers of the divine substance." ${ }_{2}$

Such, then, is the universal regressus, in which all existences are taken up into man and man into the Word. The following passageone from among many-indicates the transition from the general to the special return. " . . . By the ten virgins who went to meet the bridegroom, is represented the universal return of the whole human race (totius humanae numerositatis generalis . . reversio) to the pristine condition of Nature; but by the five wise ones, the special return of all the saints. For the number of the elect is a species of the human race. So that what is indicated is not merely the return to the ancient beginning of Nature in generalitatem humanitatis, but also the ineffable ascent beyond Nature into God Himself in specialitate deificationis. All, as was said, are to return to Paradise, but not all are to eat of the tree of life [i.e., the Word] ; or at least, all are to receive of the tree of life, but not equally. For only a fool is ignorant of the fact, that natural goods, of which all will be equally partakers [in the universal return], are the fruit of

$$
1 \text { IV. 5, } 6 .
$$


the tree of life. For Christ, as was discussed earlier, is called $\pi \tilde{\boldsymbol{\alpha}} \boldsymbol{v} \xi \dot{\boldsymbol{v}} \lambda o v$, id est omne lignum, because $\mathrm{He}$ omnium bonorum lignum est fructiferum, being Himself every good thing and the bestower of all good. All men will enjoy his fruit through the universal participation in the goods of Nature; but his elect, lifted high above all Nature, will enjoy the special height of deification."1

The special return, then, takes place only for purified souls and only through the operation of divine grace as distinct from Nature. It consists in the return of the soul not only to its Idea-its " begin-ning in Nature"-but also its elevation, far above every natural dignity, to its goal with God, as the cause of all things. ${ }^{2}$ This is realised only in the men who "not merely are to ascend to the height of the Nature present in them, but also, through the riches of the divine grace which through Christ and in Christ is given to His chosen, are to pass beyond all laws and limits of Nature superessentially into God Himself, and become one in Him and with Him."3 The universal return brings all men to those natural goods of human nature which, like all the Ideas, have their being in Christ; but this special return brings those who participate in it to "the supernatural grace and joy of deificatio "wherein the souls that are made perfect are glorified by the supernatural grace of the contemplation of God." One part of men-represented by the five foolish virgins in the parable-will return only to Adamic perfection; to the condition of man before he sinned, when the goods which he possessed were purely natural and could not yet be called virtues. But the other part of mankind will rise to that height to which man, if he had continued free from sin, would have been lifted by grace. To this height, which is the "spiritual marriage of the bridegroom," no one is admitted save those whose souls are "bright with the light of wisdom and glowing with the flames of divine love." It is above Nature, and therefore unattainable to merely natural beauty or good. To it the human spirit is uplifted only by "grace, and the merit of obedience toward the divine commands, and the merit of the purest knowledge of God which in this life it is possible to gain from Scripture and the created world."4

1 V. 38.

2 V. 38 .

3 V. 39.

4 V. 38 , 


\section{ERIGENA: THE DIVISION OF NATURE}

The special regressus, which thus takes up into itself the whole returning movement of Nature and at the same time goes beyond Nature, Erigena is careful to trace through its stages. First, within the limits of Nature, earthly body is transformed into vital movement, vital movement into sense, sense into reason, reason into spirit " in which consists the end of the whole rational creature"; so that the five natural constituents of man's being, by the taking up of the lower into the higher, become one-inferioribus semper a superioribus consummatis, non ut non sint, sed ut unum sint. Then three "supernatural and superessential" stages of ascent, which are in God, complete this return of the soul. Of these " the first is the passing of spirit into the knowledge of all the things that are next below God; the second is the transition from this science into wisdom, that is, into the innermost vision of truth so far as it is granted to the creature; the third and highest is the supernatural sinking (occasusthe going down, as of the sun) of the completely purified souls into God Himself, and, as it were, the darkness of the incomprehensible and unapproachable light, wherein are hidden the causes of all things. And then will the night be bright like the day; that is, the most hidden divine mysteries will in ineffable wise be made open to the blessed and illuminated intelligences."1

We have already seen that the first or universal stage of the regressus cannot be called mystical. And upon the whole the same must be said of this. True, the purified soul is described as "sinking into God." But the statement which immediately follows, that to these blessed souls the most hidden mysteries will be made open, seems to imply the retention of individual selfhood. And this reading of the passage is distinctly confirmed by other passages. Early in the fifth Book, Erigena, in dealing with the return of human nature, distinguishes five stages (the number differs at different places). The fourth is when the spirit, and the whole human nature, return to the primordial causes; this is, of course, the sharing of human nature in the universal regressus, which has already been dealt with. The fifth is when Nature itself with its causes moves itself to God, " as air to light." Then Erigena goes on: "God will be all in all, when 


\section{ERIGENA: THE DIVISION OF NATURE}

nothing will be except God alone. By this I do not attempt to assert that the substance of things is to perish, but that rather it is to return by the steps which have been mentioned to a better condition. For how can that perish which is destined to return to a better state? The transformation of human nature into God is, then, not to be regarded as a perishing of its substance, but as a wonderful and ineffable return into that pristine condition, which it had lost through transgression." A little later in the same chapter he points out that the bodily substance will pass over into soul, " not in order that what is may be lost, but that it may be saved in a better essence. The same is true of the soul itself, that it so raises itself to intelligence as in it to be preserved fairer and more like God. Not otherwise is it with the transition, I will not say of all, but only of rational essences, into God, in whom all things will find their goal and be one. But what has been said about the unifying of human nature without the destruction of the proper nature (proprietatis) of the individual substances, we may confirm by the view of the sainted Maximus." Then he quotes from Maximus a passage, in which it is pointed out that when men are "deified" through the grace of the incarnate God, "the whole man remains in soul and body through Nature, while through grace he has become in soul and body altogether God." "Thus," Erigena urges, "the peculiarity (proprietas) of the natures will remain intact without prejudice to their unity, and neither will the unity of the natures be removed by the peculiarity, nor the peculiarity by the unity." Still later he argues that "a unifying of human nature, with the preservation of the proprietates of the individual substances, is possible."2

1 V. 8.

2 V. 13.-Such passages show Erigena reaching out after the organic categories which neither he nor his age could possess, and for want of which his thinking was compelled to fall apart, on the one side toward the negative theology, on the other toward the affirmative. And neither side could decisively prevail. For on the one hand, without the organic and evolutionary categories the true scientific feeling for the unity of existence must lead toward Mysticism. And on the other hand, the manifold world, with its divine presences, absolut ely refuses to be dismissed. So that Erigena is really in the grasp of logical necessity. He must deal with the problem of the Many and the One; and the only possible course was, with regard to the Many to be either a Pantheist like the Spinoza of the "second metaphysic," or an Idealist (Erigena was both); and with regard to the One, to be a Mystic, so far as a Christian Iheologian of the ninth century, unable to call for the ultimate extinction of individuality, could be. 
In another way, also-a very different way-Erigena's conclusion varies from that which the beginning would have led one to expect. $\mathrm{He}$ began with, and throughout the whole discussion he continually insists upon, the great and necessary thought of Nature as one; which implies that Nature and Grace are one, the ways of Nature being manifestations of Grace, and Grace achieving its purposes through the eternal orderliness of Nature. But, as we so often have had to notice, he had not made his way, except in flashes of sudden and brilliant insight, to the organic point of view. Hence in passing down from the second Form to the third, he was obliged to admit a rift in the unity of Nature-the coming into the world of something which is absolutely unnatural, namely, evil. Then, in tracing the reverse movement this separation necessarily reappears, and, in the way which we have just seen, Grace is set apart from Nature as superior to it. Erigena's thinking, in short, when its last word is compared with its first, is at once a call for, and a prophecy of, the day when the human mind, having entered into possession of more adequate categories, should be able to repeat the assertion which he made, but could not maintain: the assertion of the unity of Nature and Grace, Law being a work of Grace, Grace being the principle of Nature.

In the fourth Form of Nature, then, which is the outcome of the process of the world, there is a universal return of the human race, and of that whole creation which was made in it and for it, to the primordial causes, and then, beyond this, there is the special return to God Himself of those who are worthy to enjoy that pure participation. In this double Sabbath-the universal Sabbath in all the works of God, the special Sabbath of Sabbaths in holy angels and holy men-the house of God will be filled, and in it each will find his own place, "some below, some above, some in the heights of Nature, others exalted above all power of Nature with God Himself. And thus that great feast will be set in order and celebrated, from which the substance of nothing that is (for substances draw their being from God) will be shut out, and to which the defect (vitium) of nothing that is (because defects have not their origin from God) will be 


\section{ERIGENA: THE DIVISION OF NATURE}

introduced. For Nature will be purified, defect winnowed away, the substantial germs of being preserved; by the flame of the divine judgment the chaff of transgressions will be burnt away, the concealed things of darkness illumined, and God will be seen as all in all."1

Such was the view of the world and of our life taken by John Scotus Erigena, a man of the ninth century. His intellect, as revealed in the De Divisione Naturae, is an intellect subtle and powerful and daring; one that can hold its steady way through a great argument and yet flash into keen and original suggestions at every step. And with all that originality went the greater qualities without which originality is the passing novelty of a day. Habitually, Erigena's mind sought the eternal; so much so, that one of the deepest impressions left upon the reader's mind by the De Divisione Naturae, in spite of all its delight in argument, is that of a strange peace which knows nothing of contention, nothing of reviling, nothing of the furious spirit of the theologians, nothing even of the contemporary world-as if the book had been written in a solitude which left no object for a man's thoughts but God and the eternal things of God. And then, too, (probably by reason as much of instinct and native sympathy as of knowledge), Erigena's was a comprehensive mind, in the sense that the three great theologies which have swayed human life, but for which in his day no clear distinction and reconciliation had been worked out, lived in it side by side. With full earnestness, Erigena gave himself to the mystical theology, which puts God altogether beyond the apprehension of reason, and union with God altogether beyond the normal forms and energies of our experience. But with equal earnestness he gave himself to the affirmative theology, upon whose positive view of the relation of the world to God the ordered universe appears as a self-unfolding or self-communication of God. And this latter theology was present in him in both the forms which historically it has assumed, the Pantheistic and the Idealistic; forms represented in modern philosophy, the one by the Spinoza of the "second metaphysic," the other by Hegel. For want of a clear possession of the higher categories he is often driven, not, indeed, to 


\section{ERIGENA: THE DIVISION OF NATURE}

Spinoza's formula of substance, attribute, and mode, but yet, none the less really, toward the essential movement of thought of Pantheism; is often driven to view the process of the universe as an unfolding from above, of such a kind that the presence in it of anything not directly and plainly of divine nature constitutes a problem of hopeless difficulty. But he continually has glimpses of Hegel's greater way; continually rises to the view of the history of the universe as a process in which Absolute Reason realises its purpose of righteousness and of good, by "externalising and diversifying itself"; by giving rise, that is to say, to individual existences, to whom life and the struggle of life are real, and through whose labours and struggles there is slowly built up that City of God in which, just because men have come to the fulness of their individuality, God is truly all in all.

Far apart as these three theologies lie from one another, Erigena found in himself a kinship of soul for each of them; to each of them he gave himself; and so became one of those men whose vocation it is to attempt the impossible, and by that attempt to serve the world and carry forward its history to new stages. But as one takes leave of him, it is not of the subtlety and brilliance of his mind, nor even of his remarkable historical position, that one cares last to speak. The best final word to say of him is, that he had high thoughts concerning God; and therefore he had high thoughts concerning man and the

destiny of man; concerning the destiny even of the men whose souls are most shrouded in darkness. 


\section{THE THEISM OF ST. THOMAS}




\section{THE THEISM OF ST. THOMAS.}

THE "Theism" of a great master of systematic theology ought in propriety to mean the whole body of his thought. It ought to signify his whole view of the world and of man. For the world, and its citizen man, have their being from God and in God; the very individuality and freedom of man are themselves a communication of His nature on the part of God. And from this it follows that the view of God, the view of the nature of the world, the view of the meaning of man's life, are correlative views. The form which any one of them has come to assume in one's mind determines, if one's thinking really is systematic, the form which the others must assume. Furthermore, that which in the order of reality is primary and determinative, is God; and that order of reality the order of our conception ought so far as possible to reproduce. It is true that in the way of natural reason we rise to the apprehension of God through the world and through our own souls. But once a conception of God is reached by us, either it becomes the organising and determinative principle of all our thinking about the world and man, or else our thought (for honourable reasons, it may indeed be-when the terrible mysteries of life have put us to silence, and we have but faith where we "cannot know") is fragmentary and not systematic.

So that a study of the Theism of St. Thomas ought to be a study of the whole body of his theology, down to its last discussion of nature or the state. But that is not possible here; it is necessary in the few pages that remain to fall below that justice, and to confine the discussion to St. Thomas" "conception of God" in the usual limited meaning of that expression. In dealing with it what we shall find is, first a doctrine concerning God which logically implies, though it does not expressly formulate, a view akin to Concrete or Objective Idealism; but secondly, this view crossed by a dualism similar in motive to that which already we have seen in Plato and Aristotle- 


\section{THE THEISM OF ST. THOMAS}

the dualism between the perfect and eternal God, and this imperfect and temporal world.

The references are to the smaller, or philosophical, Summa which St. Thomas wrote "contra gentiles." Any references to the larger-. the theological-Summa are indicated by the necessary abbreviation.

In the book Contra Gentiles we find, at the point to which our task specially leads us, the following reasoning developed. St. Thomas has by the preceding argument been led to declare that all

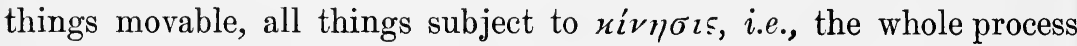
of the phenomenal world, must be referred back to unum primum movens seipsum. But can we form any conception of a self-mover? Yes, we can; and in the forty-fourth chapter of the first Book St. Thomas proceeds to do so. That which moves itself, that in which est movere et non moveri, does so per appetitum et apprehensionem. But with regard to the omnium primum movens (quod Deum dicimus), the desire cannot be for any particular or sensuous good, for anything bonum et appetibile ut hic et nunc. On the contrary, the desire must be that of the First Mover for Himself. In all His activities, $\mathrm{He}$ is Himself both the end and the source. But if God thus desires Himself, He must be viewed as esse intelligens; in fact, the title of the chapter now before us is Quod Deus est intelligens. To put this into modern language God is, upon St. Thomas' view, self-conscious and self-objectifying Reason-Reason which desires and wills itself; and this desiring and willing of itself is the bringing into being of the world.

Then, in further developing his doctrine, St. Thomas goes on to deal more at length with the self-knowledge of God. God, he says, seipsum perfecte intelligit; 1 furthermore since the intelligible form, quo Deus intelligit, is nothing other than the divine essence itself, theiefore God, primo et per se solum seipsum cognoscit. ${ }^{2}$ And in the theological Summa, to these verbs intelligo and cognosco he adds comprehendo:-Deus perfecte comprehendit seipsum. ${ }^{3}$

Still further, the knowledge of God is His very nature. Intelligere Dei est sua essentia $;^{4}$ or as the theological Summa puts it, ${ }^{5}$
1 I. 47.
2 I. 48.
3 S. T. I. 14. 3.
4 I. 45.
5 I. 14.4. 


\section{THE THEISM OF ST. THOMAS}

[Ipsum] intelligere Dei est ejus substantia. This, urges St. Thomas, follows from the preceding. God is esse intelligens. But intelligere est perfectio et actus intelligentis.

Thus, then, God is conceived as an intelligence that knows, that perfectly comprehends, itself. And this character as intelligence is the essential nature of God; it is the divine substance itself. The view of Aquinas, so far, might be summed up by saying that to him God is self-conscious, self-determining, self-objectifying Reason: selfconscious, for $\mathrm{He}$ knows Himself; self-determining and selfobjectifying, for He determines Himself through Himself, is to Himself the end of His own activities.

This brings us to the question which, for the purpose of our present inquiry, we have to ask concerning the Thomistic Theism. It has been our task to trace certain elemental oppositions in the field of philosophy and theology. The first and deepest of these is that between the negative view-which, in religious men, becomes Mysticism-and the positive view, which, when it enters into clear possession of its highest categories, is Idealism. Those highest categories are the categories involved in the idea of spirit. But as we have seen, even when these have been gained, there is still possible a more abstract and a more concrete use of them. The self-conscious and self-determining subject of the world may be viewed as in organic connexion with the whole process of the world; not merely of certain aspects of the world is God the source, but of the whole order of the world; not merely through some fragment of it is $\mathrm{He}$ realising His purpose, but through its whole process and history. Or, again, the emphasis may be put so entirely upon pure reason that the sense-world which has its being in space and time becomes metaphysically a hopeless problem, and ethically a realm to be withdrawn from. Or the abstraction may be carried still farther. The fact that self-consciousness and the objective consciousness are correlative, that consciousness of self implies consciousness of objects, and that without such consciousness of objects there is no such thing as selfconsciousness:- this may be forgotten, and the emphasis laid altogether upon the mere fact of self-consciousness, upon the mere abstract fact that "I am I," upon the bare "I think" that attends 
each fact indifferently without reference to the object that is thought. Then God can but be viewed as existing in the blessedness of such a self-contemplation as leaves the world, in some inexplicable way, apart from Him and alien to Him; one step farther in the way of abstraction would, in fact, give us Mysticism. These are the three typical possibilities in the use of the category of self-consciousness as the final principle of explanation of the world. The strife between these- a strife often implicit and unconscious-and the advance from the less to the more concrete, make up the inner history of Idealism. And the failure to distinguish them clearly is the source of some of the most troublesome difficulties that have beset Idealism in philosophy and Theism in theology.

In what position, then, does St. Thomas, with his definite enunciation of the category of self-conscious spirit, stand with reference to these possible types? The answer to this we have now to trace.

The conclusion of St. Thomas just noted was that God is essentially intelligence; intelligere Dei est sua essentia. But alongside this we have at once to set two other conclusions. The first is a conclusion with regard to the nature of intelligence which involves a view of the relation between intelligence and its objects. "Intelligere," he says, "is the activity or energising (actus) of an intelligence-an activity which exists in itself, and does not pass orer into anything extrinsic to it, as, for instance, heating passes over into that which is heated." This definition of intelligere at once raises the vital question between the abstract and the organic view. For the definition implies that whatsoever God knows is in some true sense in God. Which, then, of the two alternatives will St. Thomas take? If he wishes to separate God and the world in the sense of denying that the relation of the world to God is organic, he must deny knowledge of the world to God. While if he insists that rod knows the world, he at once makes the world intrinsic to God; makes the world the objective consciousness of God.

What he does is to assert explicitly and strongly that God knows the world; but, as we shall find, he does not see-or at any rate does 


\section{THE 'THEISM OF ST. THOMAS}

not draw-the logical consequence which this assertion carries as soon as it is taken together with his own conception of knowledge. God, he says, cognoscit alia a se. ${ }^{1}$ For, he argues, the cognition of an effect is adequately possessed (sufficienter habetur) through the cognition of its cause. Therefore, since God is through His own essence the causa essendi of other things, and since He most fully knows His own essence, it must be affirmed that $\mathrm{He}$ etiam alia cognoscat. And this position is made still stronger by the next chapter which declares that God has propriam cognitionem de rebus omnibus. ${ }^{2}$ And with this propriam cognitionem de rebus omnibus Thomas is thoroughly in earnest. In several chapters both in the Contra Gentiles and in the theological Summa he expressly affirms that God knows the things which are not; ${ }^{3}$ He knows the particular and the contingent ; ${ }^{4}$ He knows the infinite $;^{5}$ He knows the base and the evil. ${ }^{6}$ And this knowledge of God which includes all things, and is the cause of things, is not discursire $;^{7}$ does not proceed by compounding and dividing. ${ }^{8}$ On the contrary, Deus omnia simul inteligit, ${ }^{9}$ and this because $\mathrm{He}$ knows all things una specie intelligibili.

If we put these two views together we at once have the positive tendency. For with reference to all things that are, even the contingent and the evil, with reference even to the things that are not, it is declared that God omnia simul intelligit. But it is also declared that this very intelligere is "the activity or energising of an intelligence-an activity which exists in itself and does not pass over into anything extrinsic to it." The world then cannot be external to God; the disjunction between the world and God which is the essence of the negative tendency, is put decisively out of court; the world becomes nothing other than the objective consciousness of God.

But did St. Thomas either fully accept, or consistently keep himself up to, this point of view? The answer is that in part he did, in part did not. The tendency toward the more concrete view

1 I. 49: cf. Summa Theol. I. 14. 5, 6.

2 Another side of this linking together of the divine knowledge and the things of the world is seen in the principle (argued, e.g., in Summa Theol. I. 14. 8) that scientia (strictly speaking, scientia approbationis) Dei est causa rerum.

3 I. 66 ; S. T. I. 14.9.

4 I. 67 ; S. T. I. 14.11 and 13.

5 I. 69 ; S. T. I. 14.12.

- I. 70,71 ; S. T. I. 14.10.

7 I. 57 ; S. T. I. 14.7.

8 I. 58.

9 I. 55. 
is found, for instance, in the statement that God is in all things, not as though each thing were a part of His essence (so that any particular thing would be a "piece" or "mode" of the Divine Being); nor as an accident; but as the mover (agens) is present in that which is moved. It is present, again, in the discussion (found in each Summa) in which it is pointed out that the videntes Deum per essentiam would see all things in God, and would see them not successively but omnia simul:1-a view which is put in another way when it is said ${ }^{2}$ that with God vivere is one and the same thing with intelligere. In God the percept and the thing perceived and the perceiving itself are the same. But whatever is in God as perceived is his life. Wherefore, since all things which are made by God are in him as perceived (intellecta), it follows that all things in Him are the divine life itself. Or if we turn to the later Books of the Contra Gentiles-references to the Contra Gentiles have so far been to the first Book, which sets forth what would usually be called St. Thomas' "conception of God"-we find here and there hints which look in the same direction. In the second Book, for instance, which contains the doctrine of creation, he insists, in dealing with the diversities of the world, that the distinction of things from one another is not due to accident; nor is matter the first cause of it; 3 nor yet contrariety in the first agents; but on the contrary, multiplicity and variety, diversity and inequality in created things, are necessary, that by this manifoldness a perfect copy of the divine perfection might be found. ${ }^{4}$ In the third Book, whose topic is in part Ethics and in part the questions of Providence-of the divine government and administration of the world-it is asserted ${ }^{5}$ that God is omnium finis, that to know God (intelligere Deum) is the end for all intelligent creatures ${ }^{6}$ (whence it follows quod ultima hominis felicitas non sit in hac vita) $;^{7}$ that to all operating agents God is the cause of their operation (so that every operation ought to be ascribed to God as to the first and principal agent), ${ }^{8}$ and yet that this does not exclude free will in the part of the creature $; 9$ that there is a certain coincidence of natural law and divine law. ${ }^{10}$ In the fourth Book,

1 III. 59,$60 ;$ S. T. I. 12.8 seq.

4 II. 45.

8 III. 67.
5 III. 18.

9 III. 73.
2 S. T. I. 18. 4.

6 III. 25.

10 III. $128 \mathrm{seq}$.
8 II. 40.

$7^{4}$ III. 48. 
which is given to the consideration of revealed truths, we come to the doctrine of the Trinity. But to that reference must be made at a later point.

Such teachings show how St. 'Thomas can maintain the more concrete point of view. But upon the whole an abstract view prevails; or rather the rational foundations are laid for the concrete view, but hopeless difficulties intervene, and the conclusion which is finally drawn is to a very considerable extent abstract. ${ }^{1}$

The difficulties arise both from the side of the world and from the side of God. From the side of the world, its imperfection stands over against the eternal and changeless perfection of God. Metaphysically the world is imperfect, as a divided order in time and space. Ethically it is imperfect, as the seat of evil. Hence it has to be viewed as in some sense disjoined from God. Yet, as the doctrines just referred to show, St. Thomas sees that the world must be viewed as intimately in connexion with God. And as between these two necessities what he does is to adopt something like a Platonic theory of Ideas. "The forms which exist in particular things," he says, in that very chapter of the Contra Gentiles whose thesis is Quod Deus est intelligens, “are imperfect." But everything imperfect is derived from something perfect, for the perfect is prior in nature to the imperfect, just as actus is prior to potentia. Hence the imperfect forms which exist in the particular things of the world, must be derived from actually subsisting perfect forms. And these can subsist only in an intelligence. To St. Thomas this is just another proof that God is esse intelligens. But what concerns us here is that it really shows the negative tendency at work. Instead of the order of this world, even in its imperfections,

1 One result of this contrasts curiously with the position which St. Thomas has held, and still holds, as the guide of innumerable churchmen: in following the standard and master of orthodoxy, we must, if we wish to keep orthodox ourselves, be careful how we go beyond what stands written; if we take a principle from one place, and another from another, and put them together, and adopt the conclusion which logically follows, we are as like as not to be heretics. As an exceedingly keen-minded teacher of philosophy, to whom I am greatly indebt'd, once pointed out, when St. Thomas (bv reason of the very clearness and sincerity of his own mind) cannot escape doctrines which have heretical implications, he gives them their place in Grd, but forbids them to us men. He makes God pantheistic, but he will not let us be pantheistic; he makes God heretical to save our orthodoxy. 
being regarded as wholly organic to a divine purpose,-though we men cannot clearly see how, because "we see not to the close" - what is really asserted is that there are two worlds: the perfect world of ideal forms, which exists in God, or, as St. Thomas would say, in the Word; and this present world of imperfection. The doctrine of Ideas, as worked out in the greater $S u m m a,{ }^{1}$ carries the same implication; though it is limited by the statement that evil has no Idea in God, because it is known by God non per propriam rationem sed per rationem boni.

That which intervenes between the ideal world in God, and this imperfect world, is of course creation. But the Thomistic doctrine of creation $^{2}$ is rather a repetition of the doctrine of Ideas than an explanation of how a perfect God could make an imperfect world, or how the imperfection of the world can be organic to the accomplishment of a divine purpose. After pointing out that every being which in any way whatsoever exists, is of God, and that the materia prima is created by God, he goes on to discuss the question whether the formal cause (causa exemplaris) is anything beyond God. In the opening list of the arguments pro and contra he quotes the Augustinian doctrine, ideae sunt formae principales, quae divina intelligentia continentur, to prove that exemplaria rerum non sunt extra Deum and then goes on: "I give the obvious answer: God is the prima causa exemplaris of all things. And as evidence of this, let it be considered that for the production of anything, a pattern (exemplar) is necessary, that the effect may follow a determinate form. For the artificer produces a determinate form in the material by reason of a pattern upon which he looks, whether it be a pattern upon which he gazes outwardly, or one which he conceives inwardly in his mind. Moreover, it is manifest that the things which come to be in the course of nature follow determinate forms. This determination of forms, furthermore, must be brought back to the divine wisdom as to a first principle-to the divine wisdom which has conceived (excogitavit) the order of the universe which consists in the distinction of things. And therefore it is necessary to say that in the divine wisdom are the rationes omnium rerum which we have above 
called (qu. 15. art. 1) Ideas, that is, pattern forms (formas exemplares) existing in the divine mind." 'Then St. Thomas goes on to reconcile this with the doctrine we shall have presently to consider, that of the simplicity of the divine nature; and comes to the conclusion that God Himself is the first exemplar of all things. But this, it will be noticed, still leaves the disjunction. The ideal world exists in God; and then this present world exists somehow, apart from that ideal world, as an imperfect copy of it.

But, secondly, there were difficulties from the side of God. St. Thomas, with the mediæval theologians generally, is committed to the doctrine of the simplicity of the divine nature; the divine nature is such a unity as excludes diversity. ${ }^{1}$ The divine nature, St. Thomas thinks, must be such a unity, because else it would be a compositum; and that for many reasons is impossible; it would involve, for instance, the possibility of dissolution, and then, too, omne compositum posterius est suis componentibus. ${ }^{2}$

What such a view indicates is that St. Thomas, even in formally declaring that God is self-conscious and self-determining spirit, has not entered into the real significance of the category which he is using. He has failed to apprehend spirit as a principle of synthesis, of unity in diversity; as a principle whose essential nature it is to hold many elements together in the unity of one experience, at once distinguishing itself from each of those elements and each of them from one another. But so to conceive spirit is the key to the whole theistic view of the world. Continually St. Thomas comes near to such a conception; but to enter clearly upon it, and to lift it to its "full working prerogative" as a principle for the explanation of the world, was reserved for the men who carried forward the work begun by Immanuel Kant. So that St. Thomas is exposed to a great danger. For the view of the divine nature as omnino simplex, if carried rigorously to its conclusion, would put God beyond the apprehension of our reason, and union with God beyond the normal capacities of our

1 I. 18; cf. the discussion De Unitate Dei in the greater Summa where the first conclusion is: unum non addit supra ens rem aliquam, sed tantum negationem divisionis (S. T. I.11. 1).

2 Et dependens ex eis adds the theological Summa in its statement of these reasons (I. 3. 7). 


\section{THE THEISM OF ST. THOMAS}

nature. That is to say, it would lead, according to the temper of the man who held the view, either to Agnosticism or to Mysticism. Either outcome was, of course, impossible for Aquinas; not merely on account of his position in the church, but by reason also of his genuine insight into the positive character of the relation of God to the world. ${ }^{1}$ Yet when the doctrine of the simplicity of the divine nature is in the foreground of his thought, he can save himself from such an outcome only by ingenious expedients. Intellectus noster, he resolutely affirms, de Deo simplici non in vanum enunciationes format componendo et dividendo, quamvis Deus omnino sit simplex. It is true, he admits, that we come to knowledge of God by manifold conceptions, bonitas, sapientia, and the like. But then, he urges, we do not attribute the method of the knowing intellect to the things which are known-just as, for instance, we do not attribute immateriality to a stone, although we know it in an immaterial fashion. So, then, in our knowledge of God, the manifoldness of conception is to be referred to ourselves, as knowing intellects, but unity is to be referred to the God who is known.-Later, when St. Thomas has affirmed that God has propriam cognitionem de rebus omnibus, the same difficulty recurs. If the divine intelligence is omnino simplex, how can there be in it multitudo intellectorum? But here once more, instead of rising to the view of spirit as a synthetic principle, and therefore a principle at once of unity and of diversity, St. Thomas saves himself by an ingenious device. He falls back upon the theory of intelligible forms. An intelligible form is a principium formale intellectualis operationis; by means of it the knowing intelligence knows the thing; not in such a way that the knowing itself (intelligere ipsum) is an action passing over into the thing known (as heating "passes over into the thing heated"); but in such a way that the knowing remains in the intelligence, and yet has relation to the thing which is known. But the divine intelligence has no other intelligible form than its own essence, which is simple, but nevertheless is the likeness of all things. And so, by one intelligible form which is the divine nature, and by

1 The Mrstic outcome, however, was possible for St. Thomas' fellow-Dominican and, in a sense, disciple, Master Eckhart. 


\section{THE THEISM OF S'T. THOMAS}

one general concept (intentio intellecta), which is the divine Word, many things can be known by God. ${ }^{1}$

We have already seen what is implied in St. Thomas' view of the activity of the divine intelligence as one which exists in itself and does not pass over into anything extrinsic to itself. Taken in connexion with the statement that God has propriam cognitionem de rebus omnibus, it implies that the world is in God, so that in knowing the world God is not going beyond Himself, is not passing over into something extrinsic to Himself. But what we have just seen is that from both sides-that of God, that of the world-Aquinas is led to hold the two apart. And this is rendered easier for a theologian by another fact. In the genuine order of science, we start with the world of our experience, and seek to understand it; and the explanation of it we find at last in God. And then, of course, the principle of explanation and the thing explained must be viewed as standing in organic connexion-unless, as sometimes happens, the scientific inquiry forgets its own beginning. But if you start with ready-made conceptions-God, the soul, the world-you feel at liberty to link these together or hold them apart as the exigencies of your thought may require. And thus to start with separate ready-made conceptions is one of the specific dangers of the professional theologian; it is, in fact, the essence of that theological procedure known as the dogmatic.

But, in attempting to consider how far the Theism of Aquinas is positive and concrete, how far abstract and negative, we have still another question to raise; and that the central one. The difficulties which we have been considering, the opposition of what seem to be necessities of thought:-will St. Thomas find any solution for these when he comes to deal with the doctrines of the Trinity and the Incarnation? In his discussion of these, if anywhere, we may expect the concrete view to come fully to its rights. For the central conception of the Christian view of the world is that God became man, and that thus there was lived, under the actual conditions of human history, a life which is the true and normal-in the strict Platonic sense, the idealhuman life. But this involves a thoroughly concrete view. For it

1 I.e. St. Thomas really puts the two sides together in God; the diversities are put into the divine nature, which is nevertheless declared from the outset to be a unity (see Contra Gentiles, I. 36, 46, and 53). 


\section{THE THEISM OF ST. THOMAS}

implies, on the one side, that God fulfils Himself in human nature; and on the other side, that the human nature, which in the Son of Man rose to the true form of its own Idea, is potentially the divine nature. Taking the discussion in the Contra Gentiles with that in the theological Summa, one must say, however, that while St. Thomas advances toward such a view, he does not enter fully into it. Is there a procession in God? he asks. ${ }^{1}$ First, he notes some very interesting counter-arguments. For instance, (1) procession signifies movement toward the outside, but in God there is nothing movable nor extraneous, therefore no procession; (2) everything which proceeds is diverse from that from which it proceeded. But in God there is no diversity, but the completest simplicity. Therefore in God there is no procession. But, in spite of these, he holds that there is a procession in God. Not as a cause proceeding into its effect; that would give us the heresy of Arius. Nor as a cause carrying itself into its effect and impressing its own likeness thereupon; that would be the opposite heresy, the error of Sabellius. As against these Thomas holds to a procession in God; such as appears in intelligence whose activity remains in itself and there forms a concept-a verbum cordis, of which the verbum vocis is a sign. Such a procession, urges Thomas, there is in God. And it is twofold-the processio Verbi, which can be called generatio (generatio Fili) and the processio amoris. Then he goes on to distinguish these, the one (the generation of the Son) taking place secundum actionem intelligibilem, the other (the procession of the Spirit) secundum operationem voluntatis. But when it comes to bring the Son, and the Father through the Son, into organic connexion with human nature and with all the breadth of the human world, the great monastic Doctor slackens his pace. In the fourth Book of the Contra Gentiles ${ }^{2}$ he does, indeed, bring the doctrine of the first Book, that God thinks Himself, into relation with the revealed doctrine of the Word. That which was made in Him was life; i.e., as St. Thomas takes it, all things pre-existed in Him, so that He is both the Likeness of God (habet Deitatem, et est verus Deus, imago invisibilis Dei), and the original type of all created things. But this still leaves the great disjunction possible; the Word is the Idea of all

1 S. T. I. 27.

211. seq. 


\section{THE THEISM OF ST. THOMAS}

things-but yet He may not be regarded as fulfilling Himself through all things and realising $H$ is purpose in all history. In fact, one is tempted to say that with St. Thomas, as with so many later theologians, the other elements of his thought govern his doctrine of the Trinity and the Incarnation, rather than the doctrine of the Trinity and the Incarnation the other elements of his thought.

Such, in the outline of its logical motives, is St. Thomas' conception of God. So limited a statement, it is true, does not do justice to the Thomistic Theism. As was pointed out above, if justice is to be done to any man's Theism-to his real Theism, which may, or may not, be identical with his professed-the whole body of his thought must be taken into account. ${ }^{1}$ In the case of St. Thomas one would have to consider, in particular, how genuinely the concrete tendency comes to its right in his teleology: in his view, namely, of history as the process of the realisation of a divine purpose; and of the state and its laws as factors in that realisation.

But the bare logical outline now before us is enough to show that within the system, apparently so complete and full-rounded, of the great Dominican theologian, there is a deep division of mind. The dualism can, indeed, almost be put down in the set terms of an antimony. The thesis is: The world, as a single system, must have come from God-the Manichæan view simply cannot be admitted. Therefore, the world must, in the last analysis, be of the nature of God; i.e., must be essentially, and upon the whole, good. And therefore again, in some way which is difficult or impossible for the human mind in its present state to comprehend, the imperfections of the world must be organic to the purposes and activity of the divine perfection; and, therefore, still farther, the world is a true home and field of labour for the sons of God, and the normal activities that make up man's life in this world are man's true way home to the heavenly glory. But over against this thesis rises the antithesis: The world, as it stands, is manifestly imperfect, manifestly evil. Therefore, it cannot be of God; and consequently cannot be a true home or arena

1 It is no rare thing for a church teacher, who in his " Theology" has yielded to dualism -even to the extent of Manichæism-to show himself in his Ethics and Politics a sound and hearty Theist. 


\section{THE THEISM OF ST. THOMAS}

for the children of God; so that man, if he is to come to his home in God, must renounce and forsake the world.

And this division of mind is, in St. Thomas, no mere matter of individual thinking. He, under the form of a theological system, as genuinely as Dante under the form of poetry, was the expression of the mind of the Middle Ages. What that mind was-its strength through devotion to God, its weakness through injustice to nature and through the consequent sundering of nature and grace-I have already attempted to indicate. ${ }^{1}$ Its vision of the glory of God was so intense and overmastering, its sense of the evils in the world so keen, that it was driven to a separation of the divine and the natural; and so the very man who in modern times stood for its spirit of systematic comprehension, could rebuke it for not being comprehensive enough, and could say of it, that with all its zeal for the divine it made the divine kingdom the dwelling-place of the dead, attainable only through the gate of death; and the natural world just as much a realm of death, for there is no divinity in it-God being outside of nature, and therefore, nature the grave of God. ${ }^{2}$ The charge has its truth. Yet gentler words would be still closer to truth. It would be at once more kindly and more wise to say that, as a matter of historical fact, when men of searching intellect and pure heart have dealt with the actual life of the world, their conclusions have fallen in two directions and approximated to two types: the one apprehends God as the eternal truth and life of the world; the other apprehends Him as that reality in the presence of which the world fades into nothingness. The spiritual struggle of mediæval men made them so acutely sensitive to both demands that in their thought the opposed tendencies lose the sense of their opposition, and are interwoven. In Erigena both views are present, each in its extremest possible form; but with the positive taking upon the whole the greater place, especially at the close. In St. Thomas, also, both views are present; but they stand in a different relation, which reminds one a little of the ground-lines of Plato's earlier Idealism. With regard to the "real" world-the world which

1 Supra, pp. 29-33.

2 Hegel, History of Philosophy, Eng. tr., vol. III., p. 94 seq. It is the scholastic mind: that Hegel has specially in view. 
is known to angelic intelligences, but for us men is very largely a "world to come"- the positive or Idealistic view prevails completely; while, with regard to the world "that now is," that Idealism is crossed by a certain measure of the negative or abstract view. But in spite of this deep division of the mediæval mind, in spite of this distance to which mediæval men went in excluding many aspects of the world and of our life from genuine reality, we must in fairness keep open eyes for the fact that the essential spirit of mediæval thought was the spirit of unity and comprehension. The purpose of the mediæval mind was to bring all human knowledge to unity in a knowledge of God; and if this attempt was partly a success, partly a failure, alike in the ninth century when it was made by the daring and brilliant mind of Erigena, and in the thirteenth when it was undertaken by the sober and massive intelligence of St. Thomas, the reason lies, upon a last view, simply in this, that earth is not heaven and human science not the totum simul of heavenly vision.

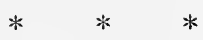

With this we must end our study of the two great ways in which the apprehension of God has shaped men's attitude toward the world and toward their own life in the affairs of the world. Mediæval men stood-where all men stand-between time and eternity; and it was their labour, both in practice and in speculation, to bring their life in time under the form of eternity. They felt the unity - the unity in God-of all existence. Hence the inner impulse of their science was to see the world as one; and to see it as one by knowing God. In the light of the knowledge of God all the contending elements and currents of the world were to take on the form of unity and eternity. But the material of which their life was made defeated that 
endeavour; the struggle of life made them feel precisely the hopeless dividedness of existence, the hopeless irreconcilability of its elements. They had fought their way, with infinite toil and pain, up from chaos; with infinite toil and pain were subduing the flesh to the spirit, and the passions of the earth to heavenly light. God and the world stood for them far asunder; between the two they must choose; and they chose rather to lose themselves with God than to be masters of the world. As a man sitting in the midst of music and of dreams hears far out in the night the call of the trumpet, and recognises his greater rocation, and turns to the long march through the darkness, and to the battle that with its chances of life and death waits the break of day; so the leaders of mediæval religion turned from the allurements of the beautiful and terrible world, and allowed to their hearts no love save the heavenly love, ${ }^{1}$ and gave themselves to the one task of so organising society that it should be, in labour, in discipline, in vision, a training-school for the life to come. So that the final insight to which both their life and their science led them, defeated in part the impulse with which their science began. All things of the world are one in God; and therefore to know the world as it truly is we must know God. But so soon as we come to a knowledge of God, we come to that which condemns the world. Through all things there runs the absolute and final distinction between God and that which is not God, between heaven and the awful eternity of hell. And man, as he looks upon God and upon that twofold issue of his own life, stands in a strait with regard to all the things of this world and all the appeal which they make to his heart. We must love God; but whether we can love Him in loving the things which He has made is a problem of hopeless difficulty; for the things which $\mathrm{He}$ has made have somehow come to be full of evil. On the one hand, there is no source of real existence but God; and, therefore, throughout the whole of existence, with all its trouble and toil and darkness-its "desperate and hideous years," its "wrong too bitter for atoning "-God must be achieving a vast design. But on the other hand, the world is evil

1 If we turn from Aquinas to Dante, the fact remains that, while Dante's love nerer loses its humanity, it maintains itself only by lifting itself from earth to heaven. The Beatrice whom Dante loved through all his greater years was the Beatrice who, among the blessed, looked upon the face of God. 
while God is good; therefore, the world is alien to God, and the sons of God must renounce it. Such was the problem laid upon mediæval men by that wisdom which is the inner soul of the ages, the wisdom which allots to each mortal generation its toil, and leads each by the burden of hopeless difficulties into a citizenship of eternity. With that problem mediæval men did the best that they could do: they admitted both solutions to a place in their thought, and became at once Idealists, serving God by mastering the world, and Mystics, finding God by renouncing both the world and their own individuality.

For modern men the problem of life, however different in appearance, is not different in essence. On the one side, for us as for them, stands the evil of the world. And its distinctively modern form-the industrial and social selfishness which allows whole classes of human beings to live here upon the earth in hell-is, with all its refinement, a profounder form of evil than that savage power of the flesh which mediæval men had to overcome, as, in obedience to a light from heaven, they lifted themselves out of their northern barbarism. But if that which shows the world as divided and broken has taken on an intenser form, so also has the demand for unity; the demand, namely, that the world shall be seen as one order of existence framed throughout for the realisation of one supreme purpose; and that, therefore, all the interpretations of the world, scientific, moral, religious, shall lead to a common centre. This demand arises from all sides of the modern situation; alike from the scientific side, and from the religious and moral. For science can admit no dualism; at every point in its work it presupposes and implies the unity of all existence, and the continuity of the whole cosmic process, including man and all that makes up man's life. While theology (and still more the religion of which theology is the intellectual expression or shadow) with its central presupposition of the supremacy of God, just as truly demands the unity of all existence and the continuity of the whole process of the universe; and that whether we interpret the supremacy of God in Christian and paternal terms, or in Roman and forensic. And the moral consciousness, which seems most of all to force a dualistic belief upon the pure heart and the upright spirit, really calls for an ultimate unity. As Plato saw, the Chief Good must be 
one, and it must be the supreme principle of Being. It must be the highest principle of the whole system of existence as well as of man's moral endeavour. For in the last analysis the Good for man must be the divine nature; and for the attainment of it-the genuine and difficult, not the easy and fictitious, attainment of it-the whole order of the world must be framed.

In some respects, modern thought, with all its dividedness, is in a better position than mediæval to meet that demand. For one thing, we have a keener sense of the difficulty of the task. Mediæval men boldly attempted to unify reason and faith, science and revelation. But if we moderns are acutely conscious of any one thing more than of any other, it is that such unification must be achieved, if at all, in some greater experience to come ubi ipsa veritas vita animae nostrae erit. We are content to speak, not of unifying, but of reconciling. Anything that could fairly be called the unification of science and revelation would require completed (i.e., eternal) science, completed revelation, and complete intellectual vision; whereas we ourselves, and our science, and our revelation (so far as revelation means something apprehensible by the human spirit), are all alike incomplete in the sense of existing under the form of time. But we can seek to reconcile with each other the two great powers which make up our spiritual life-the scientific reason which sees the world as an order of continuity and changeless law, and the religious spirit which organises life in accordance with a faith in God:-to reconcile these in a reasoned belief that the world is a divinely-ordered system and its history a divinely-guided process. ${ }^{1}$ Then, too, for men who see things as they are, the steady advance of science and its strengthening of its own position bring hope rather than fear. The man who sees nature as an order of unchanging law, is better qualified to advance to the view that the cosmic process is, in constitution and purpose, divine and divinely rational, than is the man who sees that

1 It should be understood that, if men of science have a difficulty in admitting this belief, theologians have a still greater difficulty in holding it consistently. The intellectual pressure upon a theologian is a terrible one; and the clearer his mind the more terrible the pressure. Faith in God, and the fact of evil, constitute when taken together the last and most awful of all the problems by which the human mind is tried. The theologian is always exposed to the temptation to be a Theist toward his opponents, but a Manichæan within his own system. 
process as subject to arbitrary divine fiats (a view which implies that the ordinary process of the world goes its own way upon some nondivine level, but subject to interference from above). ${ }^{1}$ Science and religion, in fact, by doing justice to themselves, enter into deeper kinship with each other. Or perhaps it would be more accurate to say that religion, since it includes the whole of life, can never do justice to itself without taking up into itself the spirit of science. And, to some extent, that is being done to-day. Theology, for example, is being transformed by a genuinely scientific study of the religious experiences and types of mind recorded in the Bible, and specially of that mind of Jesus which is at once the fulfilment and the illumination of those experiences; and, as so transformed, is becoming less and less a declaration made on the authority of the church, and more and more an expression of the facts of actual life, and of the faiths involved in those facts.

So that on the intellectual side the situation certainly grows more hopeful age by age. But in the world of to-day that which stands darkly in the way is a fact of another order. It is not a fact arising from the essential relations between the scientific and the religious mind. It has really little to do with any conflict between the scientific spirit and the spirit of the organised church, or between the scientific principle of continuity and all that love, all those hopes and visions, which have in the heart of man a natural temple. The seat of it is in the temper with which we live the practical life. Mediæval men were so intent upon God that they saw Him in and for Himself, but did not with sufficient clearness see Him in the ordinary and the everyday, in the phenomena of nature, in the layman's life. But we, throughout our whole organisation of commerce and society, have so given ourselves to ourselves that we do not like to keep God in our thoughts at all. In a social and industrial order where the weak serve the successful we labour proudly and masterfully, each man seeking by "length of watching, strength of mind" to build a city for himself. It is hard for us to give ourselves to God, and to citizenship in the city where there is no selfishness, no impoverishing or crippling of one life to maintain the splendour of another, but the good that 
all men serve is a common good. And this habit of living eách for himself is not only the source of innumerable and cruel evils; it even infuses a soul of evil into the very activities which, if performed as unto God, would be a fulfilment of His purpose.

By this it is not meant that we modern men can save ourselves from ourselves only by returning to the mediæval position. Still less is it meant that we can save ourselves from the lower world which is too much with us, only by turning back to that ancient theology before whose overmastering vision of God the world faded into nothingness as dreams fade at break of day. On the contrary, we can save ourselves only by being true to that greater world which we have discovered and made our own. But what such fidelity to the world really involves depends upon what the world is. And the truth of the world, the truth both of ourselves and of the world, is God; God, and that "far-off divine event" which is the purpose of God, are the meaning of the world. And this means that the citizenship to which we are called is a heavenly citizenship; but it also means that that heavenly citizenship must first be fulfilled upon the earth, in the life in which our duties are those of the good neighbour, the honest citizen, the devoted churchman. The perfection of human life lies in being at one with God; but to that oneness with God men can come, not by departure from the world into eternal quietude, but only by flinging themselves into the labours and causes of the history in which God is realising His eternal purpose. The true inspiration of a man's life is the love of God, its true object the glory of God; but that glory is one of work and of struggle rather than of silent peace. We have much to learn from the mystic saint in the loneliness of his rest in God. But his securely-guarded peace is not for us. Even while we honour him, we must turn our faces toward a life at once more commonplace and more divine. The man to whom the love of God is the central impulse of life must take his place in the world, must share in its labours and duties and affections and losses, must undergo the fate which it has for all its citizens. And that fate is seldom a light one. They who in the manifold relationships of life and in the affairs of the world seek to be faithful to God and man, are likely to come at last before God bearing deep marks of toil and 


\section{CONCLUSION.}

storm; like ships that within them carry high and gentle hearts, but can look for no escape from the dangers that are native to the sea, and come at last to harbour weather-beaten, scarred by lightning and tempest and hidden rock. To many-and they are not the forgotten of God-is not given the life of those who dwell here upon the earth in great peace, looking upon God, and in all the fierce storm of the world seeing nothing but God. Most of us labour with a more troubled blending of anguish and calm, of remorse and hope, toward our west. But when the light of day is passing from the sky, and through the shadow there begins to break that other light of the stars from their infinite spaces, and the worn hands that have laboured hard in the world's affairs begin to stretch themselves out "for love of the farther shore," then the man as he turns to the untravelled world which awaits him across the darkness may know at least this: already in this world he has had his part in the realisation of a purpose of God; and in the world to come that which waits for him, and for his fellows, and for all the human struggle, is not less of God, but more. 


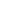




\section{INDEX.}

Agnosticism, 4, 344 .

Apologists, the, 272.

Aquinas, see St. Thomas.

Areopagite, the, see Dionysius.

Aristotle, 7, 58, 59, 60, 90, 220, 253-259, 260, 261, 267, 294, 302, 303, 304, 308, 335.

bar Sudaili, Stephen, 273.

Boethius, 97n.

Bradley, F. H., 219n2, $233 n$.

Calvinism and Arminianism, $79 n$.

Cause, the conception of, as used by Spinoza, 172 .

Creation, must begin with something less than perfection, 242, 258, 303, 308 . Cf. 82 seq.

Cudworth, 88n.

Dante, 310, 350n.

Descartes, 59, 114, 154-158, 159, 160, 161, 193, 219, 271.

Dionysius the Areopagite, 273, 277, 279, 287, 289, 290, 291.

Eckhart, Master, 147, 164, 165, 219, 344n.

Erigena, 14, 220, 267, 271-331, 348.

Freedom and Necessity, 78, 79 (with note 2), 102-105, 178 (with note 2), 179. -in Spinoza, 183, 184.

Goethe, 198n.

Green, T. H., 8, $26 n, 63,64$.

Hegel, 52, 60-63, 90, 114, 194, 195, 301, 312, 330, 331, 348.

Herder, 198.

Hierotheus, 273.

Hume, $59 n, 113,114$.

Idealism

-compared with Mysticism, 7-12, 83n, 115-122, 287n.

- the types of, Abstract and Concrete, 12, 225, 227, 231, 232, 233, 235, 235.247, $251-263,265,266,335,33 i, 338-349,350,351$.

-of Aristotle, 253-259.

- of Christianity, 262-266.

—of Erigena, see 271-331, but specially 310-312, 316 seq., 327-331.

-of Plato, 203-247.

-in Spinoza, see 176-195.

-the Idealistic position outlined, 17-110. 


\section{INDEX}

Kant, 2, 46, 59, 93, 114, 125, 126, 180, 194, 195, 219, 220, 267, 342.

Manichæism, 70n, 99, 221, 266, 307, 319, 347n, 352n.

Materialism, 4, 38, 39, 47, 53n.

Maximus the Confessor, 273, 291, 323, 328.

Mediæval view of the world, 29-34; see also Erigena, Mysticism, St. Thomas.

Mysticism

-compared with Idealism, 7-12, 83n, 115-122, 287 $n$.

-in Parmenides, 126, 127-132, 217.

-Hindu, 126, 132-141, 217.

-Neo-Platonic, 126, 141-144, 272-274; and see Plotinus.

- Mediæval, 126, 145-150, 162, 217-219; and see Erigena.

-Modern, 151, 15:.

-in Spinoza, 115, 116, 152-165.

-in Plato, 58, 124, 125, 214-232, 236.

-in Erigena, see 271-331.

Necessity, see Freedom.

Neo-Platonism, see Mysticism and Plotinus.

Newman, J. H., 17-23, 27, 28, 32, 50, 53, 73, 75.

Origen, $80 n, 88 n, 292,319,321$.

Pantheism, 287n, 311 ; and see Spinoza and Erigena.

Parmenides, 59n, 126, 128-131, 135, 136, 152, 157n, 159, 161, 162, 217, 236, 285.

Cf. $140,147$.

Plato, 2, 7, 11, 13, 25, 46, 57, 58, 59, 93, 94n, 96 (with note), 108, 109, 124, 125, 203. $247,251-253,255,256,257 n, 258,259,260,267,272,285,294,301,302,303$, 304, 30خ, 308, 317, 335, 348, 351.

Plotinus, 142-144, 175, 284-286, 291, 292, 297, 298, 301, 312.

Renaissance, the, 35, 59 .

Royce, 204, $213 n 3$.

St. Thomas, 14, 40, 90, 145, 175n, 220, 267, 335-349.

Spinoza, 59, 113-199, 219, 220, 2⿺辶7, 271, 286, 330,331.

Stevenson, R. L., 317.

Stoics, 253, 260, 261 .

Wordsworth, 23-29, 32, 50, 53, 74, 75, 100n, $198 n$. 



\section{PLEASE DO NOT REMOVE \\ CARDS OR SLIPS FROM THIS POCKET}

\section{UNIVERSITY OF TORONTO LIBRARY}

Philos

Blewett, George John

$\mathrm{B} 6 / 7 \mathrm{~s}$ The study of nature and the vision of Gor 


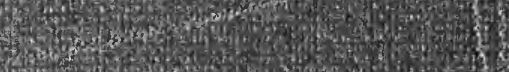
2.0. (5) 6.

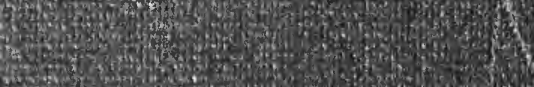
30. 